\title{
THE NEW ENGLAND COD FISHING INDUSTRY AND MARITIME DIMENSIONS OF THE AMERICAN REVOLUTION
}

\author{
by \\ Christopher Paul Magra \\ B.A., Grove City College, 1999 \\ M.A., The Pennsylvania State University, 2001
}

Submitted to the Graduate Faculty of

School of Arts and Sciences in partial fulfillment

of the requirements for the degree of

Doctor of Philosophy

University of Pittsburgh 


\section{UNIVERSITY OF PITTSBURGH \\ SCHOOL OF ARTS AND SCIENCES}

This dissertation was presented

by

Christopher Paul Magra

It was defended on

May 25, 2006

and approved by

Jonathan Scott, Professor, Department of History

Van Beck Hall, Associate Professor, Department of History

Deryck Holdsworth, Professor, Department of Geography

Dissertation Advisor: Marcus Rediker, Professor, Department of History 
Copyright (C) by Christopher Paul Magra 2006 


\section{THE NEW ENGLAND COD FISHING INDUSTRY AND MARITIME DIMENSIONS OF}

\section{THE AMERICAN REVOLUTION}

Christopher Paul Magra, PhD

University of Pittsburgh, 2006

The American Revolution cannot be fully understood without coming to terms with why workers and merchants within the New England cod fishing industry resisted British authority and how their labor and capital contributed to the war effort. The Revolution began in New England with the shot heard around the world in Concord, Massachusetts. New England provided the most manpower for the American military each and every year of the war. And cod represented the most lucrative trade good in all of colonial New England. Between 1768 and 1772, fish represented 35\% of New England's total export revenue. The second most valuable export commodity, livestock, represented only $20 \%$ of this revenue stream. By 1775 , an estimated 10,000 New Englanders, or 8\% of the adult male working population, labored in the fishing industry. Yet, to date there has not been a systematic effort to investigate the relationship between this vital colonial industry and the Revolutionary War.

In order to get at the linkages between the worlds of commerce and the way of war I triangulated data culled from merchant ledgers, ship’s log books, customs records, shipping records, diaries, newspapers, and military service records. Drawing on these sources, the dissertation defends a two-fold argument. First, economic competition between vested interests in the British Empire, principally New England fish merchants, West Country fish merchants, and West Indian sugar planters, resulted in a series of commercial regulations and naval police actions aimed at restricting New England's economic expansion. These regulations and actions 
culminated in the British state's fateful decision in 1775 to close the New England cod fishing industry, which ultimately motivated colonists to go to war. Second, fishermen and fish merchants played key roles in winning the war. Merchants converted trade routes into military supply lines and transformed their fishing vessels into warships. Fishermen armed and manned the first American navy, served in the first coast guard units, manned privateers, and fought on land. These multi-faceted efforts helped secure American independence. 
TABLE OF CONTENTS

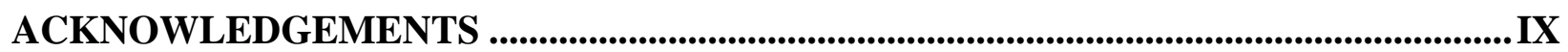

1.0 INTRODUCTION................................................................................................ 1

$\begin{array}{llllllll}2.0 & \text { THE NATURE } & \text { OF } & \text { WORK IN THE EIGHTEENTH CENTURY }\end{array}$ MASSACHUSETTS COD FISHING INDUSTRY.................................................................... 14

2.1 TRANSITION ................................................................................................... 23

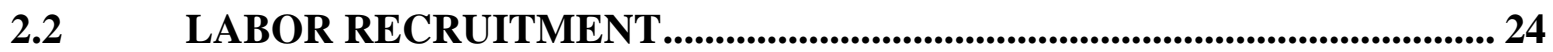

$2.3 \quad$ LABOR HIERARCHY ...................................................................................... 35

$2.4 \quad$ CAPITAL INVESTMENT ….................................................................................. 43

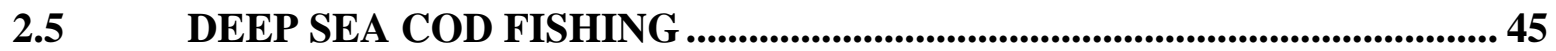

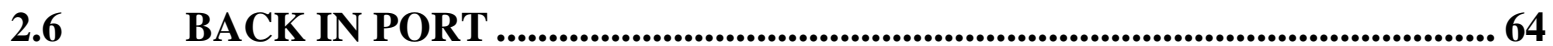

2.7 SHIPPING COD .................................................................................................. 76

$2.8 \quad$ EXPLOITATION ............................................................................................. 79

$2.9 \quad$ MULTI-FUNCTIONAL OCCUPATIONAL IDENTITY _............................. 83

3.0 THE RISE OF THE NEW ENGLAND COD FISHERIES IN THE ATLANTIC

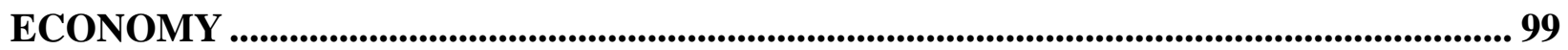

3.1 WESTWARD EXPANSION AND THE RISE OF THE ATLANTIC COMMERCIAL COD FISHING INDUSTRY _....................................................... 102 
3.2 NEW ENGLAND'S BIOGEOGRAPHIC COMPARATIVE

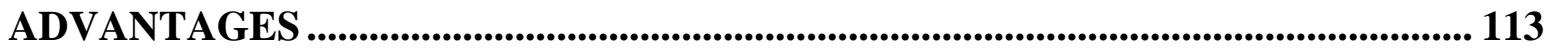

3.3 WHY ENGLAND WAS THE FIRST TO ESTABLISH A RESIDENT

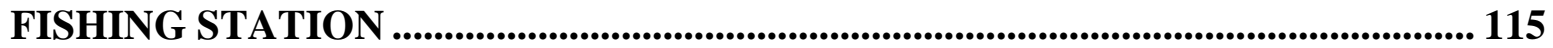

3.4 THE BIRTH OF RESIDENT NEW ENGLAND FISHING STATIONS .. 117

3.5 THE MATURATION OF RESIDENT NEW ENGLAND FISHING

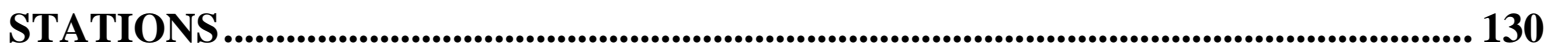

4.0 COD AND ATLANTIC ORIGINS OF THE AMERICAN REVOLUTION..... 148

4.1 NEW ENGLAND'S ECONOMIC EXPANSION IN THE WEST INDIES157

4.2 THE POLITICAL RAMIFICATIONS OF NEW ENGLAND'S WEST

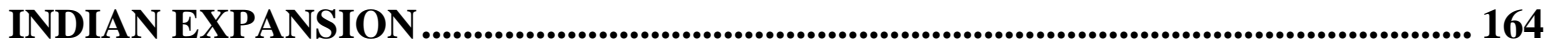

4.3 NEW ENGLAND'S ECONOMIC EXPANSION IN THE NORTH

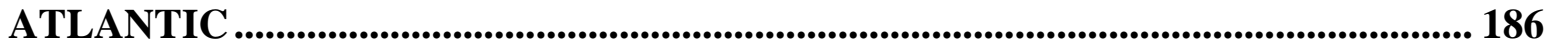

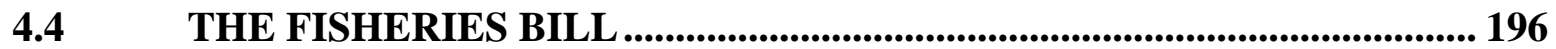

5.0 THE SINEWS OF WAR: PROFIT AND THE MILITARY MOBILIZATION

OF A PEACE TIME INDUSTRY .............................................................................. 205

C.1 CONVERTING TRADE ROUTES INTO SUPPLY LINES...................... 210

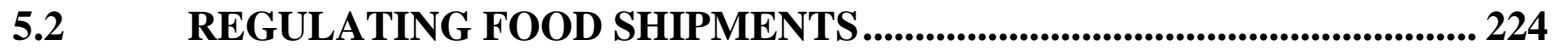

PROVISIONING THE ARMED FORCES ......................................... 235

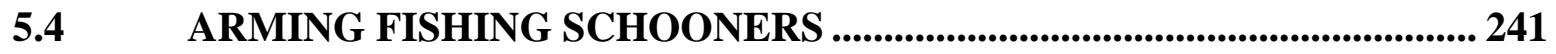

FROM FISHERMEN TO FIGHTING MEN ....................................... 261

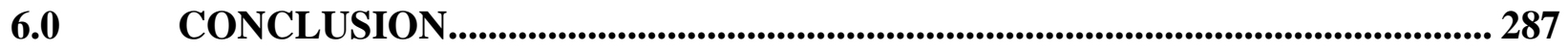

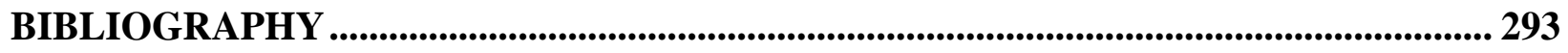




\section{LIST OF FIGURES}

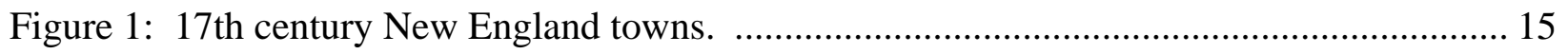

Figure 2: Northwest Atlantic Fishing Grounds A........................................................ 48

Figure 3: Northwest Atlantic Fishing Grounds B........................................................... 50 


\section{ACKNOWLEDGEMENTS}

A dissertation, like any seaworthy vessel, is the product of much accumulated knowledge. While crafting a work that I hope will float, members of my committee have generously given of their time and expertise. I am very grateful to Marcus Rediker, Jonathan Scott, Van Beck Hall, and Deryck Holdsworth. I especially want to thank Professor Rediker for piloting me through scholarly seas that were not always calm. Daniel Vickers charitably and patiently answered numerous research questions. William M. Fowler, Jr., Ken Morgan, and William A. Pencak reviewed chapters of the dissertation and offered valuable suggestions on improvements. The net worth of this collective knowledge is a debt I can never fully repay.

Certain organizations have provided financial support that has enabled me to research and write my dissertation. The University of Pittsburgh awarded me the Samuel P. Hays research grant, which helped cover costs associated with travel expenses and research costs. The University's Andrew Mellon Predoctoral Fellowship further covered these costs and afforded me time away from teaching to write. Research fellowships from the Peabody Essex Museum in Salem, Massachusetts and the Massachusetts Historical Society in Boston, Massachusetts made it that much easier to complete the dissertation. I am grateful to these fine institutions.

I also want to acknowledge the librarians and archivists at the sites I visited for research. Staff at the National Archives, the Maritime History Archives, the Massachusetts State Archives, the Massachusetts Historical Society, the James Duncan Phillips Library, and the Marblehead 
Museum and Historical Society were all knowledgeable and helpful. I am especially grateful to Karen MacInnis for introducing me to Marblehead.

My largest debt belongs to my family. My father worked his whole life so that I might live mine. My mother has never wavered in her love and support. My brother has always motivated me. Most especially, my wife sacrificed her own goals to help me achieve my own. No one could have a more loving family, nor could anyone love their family more in return. 


\subsection{INTRODUCTION}

"The history of Sea Power is largely, though by no means solely, a narrative of contests between nations, of mutual rivalries, of violence frequently culminating in war." - Alfred Thayer Mahan, The Influence of Sea Power Upon History, 1660-1783 (New York: Dover Publications, Inc., 1987; originally published by Little, Brown, and Company, Boston, in 1890), 1.

After a long transatlantic journey, which included a sailing time of approximately eight weeks, the brig Pitt Packet was homeward bound on April 22, 1769. A rising April sun would have melted fog and warmed chilled hands in the early spring morning as the brig's crew made preparations to enter the harbor at Marblehead, Massachusetts. ${ }^{1}$ Thomas Power, the Pitt Packet's master, probably shouted orders for tack and sheet lines to be hauled-in and secured as the brig angled toward the harbor mouth. ${ }^{2}$ A chorus of barefoot seamen would then sing pulling songs, or sea chanties, in order to lend a cadence to barehanded tacking labors. ${ }^{3}$ Singing and working, anticipating long absent family and friends, the Pitt Packet's crew prepared to come home.

\footnotetext{
${ }^{1}$ Marblehead weather patterns for the month of April were observed and recorded by Ashley Bowen in his journals. Phillip Chadwick Foster Smith, ed., The Journals of Ashley Bowen (1728-1813), Vol.1-2, (Portland, Maine: Anthoensen Press, 1973). While Bowen did not record the weather for April, 1769, he did make such observations for the two previous Aprils. See, ibid., Vol. 1, 153, 175. The Pitt Packet's crew comprised a captain, a mate, a master mariner, a cook, and four common seamen. L. Kinvin Wroth and Hiller B. Zobel, eds., Legal Papers of John Adams, Vol. 2, (Cambridge: Harvard University Press, 1965), 277, 313-320. The average sailing time was based on the round trip from Boston to London in the eighteenth century. Ian K. Steele, The English Atlantic 16751740: An Exploration of Communication and Community (Oxford: Oxford University Press, 1986), 57.

${ }^{2}$ See, John Harland, Seamanship in the Age of Sail: An Account of the Shiphandling of the Sailing Man-of-War, 1600-1860, Based On Contemporary Sources (Annapolis, MD: Naval Institute Press, 1984), 145-154.

${ }^{3}$ Frederick Pease Harlow, Chanteying Aboard American Ships (Meriden, CT: Barre Publishing Company, Inc., 1962).
} 
The brig belonged to Robert "King" Hooper, proprietor of one of the largest fish merchant houses in Marblehead, which was then the principal commercial fishing port in New England in terms of capital investment, number of vessels, and manpower. ${ }^{4}$ The Pitt Packet's crew had transported their dried, salted cod to overseas markets in Spain, just as had a smaller percentage of other colonial crews in the eighteenth century. ${ }^{5}$ There, the processed fish was sold to merchants in ports such as Bilbao and Cadiz. Typically, crews returned with fruits, loads of salt, lines of credit, and manufactured goods from England. On this particular voyage, the Pitt Packet was returning directly from Cadiz with salt for Marblehead's commercial fishing industry. ${ }^{6}$

The brig did not reach Marblehead's harbor that chilly April morning, however. Dawn’s early light also illuminated bent backs and busy hands on board the British Naval frigate Rose, which was patrolling Atlantic waters along New England's coastline. The Rose's Captain, Benjamin Caldwell, sent Lieutenant Henry Gibson Panton with several armed men to board the Pitt Packet early Saturday morning on the pretext of searching for contraband. But, Caldwell's real intent was to press men into naval service. ${ }^{7}$ With its sails trimmed in preparation for homecoming the Marblehead brig could not evade the Rose and its press gang.

\footnotetext{
${ }^{4}$ In addition to his involvement in the transatlantic fish trade, Hooper owned a ropewalk and donated funds for Marblehead's first fire engine. Marblehead Town Records, Office of the Town Clerk, Abbot Hall, Marblehead, Massachusetts, March 19, 1751. For more on Hooper, see the short biography in Smith, ed., The Journals of Ashley Bowen (1728-1813), Vol. 2, 661. For more on Marblehead, see Christopher P. Magra, “'Soldiers...Bred to the Sea': Maritime Marblehead, Massachusetts and the Origins and Progress of the American Revolution,” New England Quarterly, Vol. LXXVIII, No. 4, (December 2004), 531-562.

${ }^{5}$ A majority of colonial shipments of dried cod went to the West Indies in the eighteenth century. See chapter three.

${ }^{6}$ For the Pitt Packet's cargo on the day of its impressment and seizure, see Customs Commissioners to Salem Customs Officers, April 27, 1769, Salem Custom House Record Book, 1763-1772, folders 280-281, JDPL. For more on the Atlantic trading nodes associated with the Hooper House and Pitt Packet, see Smith, ed., The Journals of Ashley Bowen (1728-1813), Vol.1-2.

${ }^{7}$ On Captain Caldwell's orders, and his intent to impress, see the eyewitnesses' testimony compiled in “Adams' Minutes of the Trial,” Wroth and Zobel, eds., Legal Papers of John Adams, Vol. 2, 293-322.
} 
The crewmembers on board the Pitt Packet, however, were not willing to surrender once Panton and the press gang boarded the brig. Michael Corbet, Pierce Fenning, John Ryan, and William Conner, Irishmen who called Marblehead home, picked up "fish gig, musket, hatchet, and harpoon,” and stood ready to forcibly resist impressment. ${ }^{8}$ It is likely that the brig served double duty in Hooper's employ as a fishing vessel and a trading vessel, and the work tools had simply been left on board during the trade voyage. In any case, the four common seamen, those directly in danger of being impressed, armed themselves with fishing implements and retreated inside the brig.

The resistance quickly escalated. After a tense standoff amidst piles of salt in the forepeak, Corbett drew a line on the floor using salt and dared the press gang to cross it. Panton unwisely took up this challenge, stepped over the salt line and advanced towards "the Ship’s People.” Corbet then launched the harpoon he had been holding, which struck Panton in the neck severing his jugular vein. The British Lieutenant fell, his men carried him to the main deck, and he bled to death. During the ensuing mêlée, two Marbleheaders were shot and severely wounded. The fishermen were then arrested and tried for murder. ${ }^{9}$ Their trial gained notoriety throughout the colonies. ${ }^{10}$ In the end, the maritime laborer's defense attorney, who was none other than John Adams, was able to get the men acquitted on the basis that Panton's death occurred as a result of justifiable homicide in self-defense.

The Pitt Packet affair raises questions about the nature of colonial resistance to British authority during the 1760s and early 1770s. Who were these seafaring men? Were they

\footnotetext{
${ }^{8}$ Wroth and Zobel, eds., Legal Papers of John Adams, Vol. 2, 277.

${ }^{9}$ For more on this event, see Magra, “'Soldiers...Bred to the Sea,"” 531-562.

${ }^{10}$ Boston Chronicle, April 27, 1769; Boston Gazette, May 1, 1769; for coverage in the Boston Evening Post, the New York Journal, and the Pennsylvania Chronicle, see Oliver Morton Dickerson, comp., Boston Under Military Rule, 1768-1769, As Revealed In A Journal of the Times (Wesport, Conn.: Greenwood Press, 1971; orig. pub., 1936), 94-95, 104-105.
} 
fishermen, mariners, or both? How did their labor skills and the nature of their sea work contribute to their resistance and their willingness to resist? Why was the British Navy patrolling colonial waters, intercepting vessels, and impressing colonial seamen? How did the wider colonial maritime community, merchants and laborers, react to these transgressions? Were people in coastal communities, people like these seafarers, more prone to join the revolutionary movement than others? Did Parliament condone the Navy's actions in North Atlantic waters? All of these questions center on the sea and require an investigation of the maritime dimensions of the American Revolution.

This dissertation shows that the Pitt Packet affair revealed deep internal tensions, predicated upon command of the sea, within the early modern British Empire. Alfred Thayer Mahan, the most prominent American naval theorist, was only partially correct when he asserted that the race to dominate the seas commercially and militarily was "a narrative of contests between nations." ${ }^{11}$ To be sure, European powers fought with each other for maritime supremacy all over the world during the early modern period, 1500-1800. Spain sent its armada to the shores of England in part to prevent Elizabethan pirates from plundering New World treasure fleets in the Atlantic. The naval arms race and maritime commercial rivalry between the Dutch Republic and England in the early seventeenth century contributed to tensions that resulted in the first of a series of global wars between these two powers. ${ }^{12}$ It cannot be denied that maritime matters played roles in causing wars between European powers.

\footnotetext{
${ }^{11}$ Alfred Thayer Mahan, The Influence of Sea Power Upon History, 1660-1783 (New York: Dover Publications, Inc., 1987; originally published by Little, Brown, and Company, Boston, in 1890), 1. Emphasis my own.

${ }^{12}$ Jonathan I. Israel, The Dutch Republic: Its Rise, Greatness, and Fall, 1477-1806, $4^{\text {th }}$ ed., (Oxford, England: Oxford University Press, 1998); Garrett Mattingly, The Armada (Boston: Houghton Mifflin, 1959); and Charles Wilson, Profit and Power: A Study of England and the Dutch Wars (London: Longmans, Green and Co., 1957). For the modern era, see Robert K. Massie, Dreadnought: Britain, Germany, and the Coming of the Great War (New York: Random House, 1991); and Bruce Mitchell, "Politics, Fish, and International Resource Management: The British-Icelandic Cod War,” Geographical Review, Vol. 66, No. 2 (April, 1976), 127-138.
} 
Yet, struggles over the sea also fostered internal divisions within empires. Over the course of time, from the first permanent settlement of a resident fishing station in Marblehead, Massachusetts in 1631 to the shot heard around the world in April, 1775, colonial New Englanders built a maritime industrial complex that eventually challenged England's (and, after 1707, Great Britain’s) commercial control over the Atlantic Ocean. Robert “King” Hooper, like other colonial merchants, believed it was his right to conduct overseas trade. Michael Corbett, his shipmates, and others like them felt they had the right to earn wages to provide for themselves and their families through maritime labor. For their part, Captain Caldwell and Lieutenant Panton were following not only naval tradition but specific orders handed down from the King, Parliament and the Admiralty in halting colonial shipping and forcibly taking workers into naval service. In short, at the heart of the American Revolution lies a complex sea story about colonial New Englander's maritime expansion and the British state's attempt to control and command the colonists' relationship to the wider Atlantic world.

Excellent work has been done on the rise of a maritime industrial complex in colonial New England. ${ }^{13}$ Particular attention has been given to the roles merchants played in the development of overseas trade routes and the construction of wharves, warehouses, and other forms of maritime commercial infrastructure. ${ }^{14}$ Important research has also been done on the

\footnotetext{
${ }^{13}$ For general overviews, see Benjamin W. Labaree, William M. Fowler, Edward W. Sloan, John B. Hattendorf, Jeffrey J. Safford, and Andrew W. German, America and the Sea: A Maritime History (Mystic, Conn.: Mystic Seaport Museum Publications, 1998); and Robert G. Albion, William A. Baker and Benjamin W. Labaree, New England and the Sea (Mystic, Connecticut: Mystic Seaport Museum, Inc., 1972). Also, see the collected essays in Seafaring In Colonial Massachusetts: A Conference Held By the Colonial Society of Massachusetts, November 21 and 22, 1975 (Boston: The Society; distributed by the University Press of Virginia, 1980).

${ }^{14}$ Stephen J. Hornsby, British Atlantic, American Frontier: Spaces of Power In Early Modern British America (Hanover: University Press of New England, 2005); Simon D. Smith, “Gedney Clarke of Salem and Barbados's Transatlantic Super-Merchant,” New England Quarterly, Vol. 76, No. 4 (December 2003), 499-549; Phyllis Whitman Hunter, Purchasing Identity in the Atlantic World: Massachusetts Merchants, 1670-1780 (Ithaca, NY: Cornell University Press, 2001); Stephen Innes, Creating the Commonwealth: The Economic Culture of Puritan New England (New York: W.W. Norton, 1995); Bernard Bailyn, The New England Merchants in the Seventeenth
} 
roles women played in the economic expansion and social development of colonial ports in the region; ${ }^{15}$ the rise of New England's shipping and merchant marine; ${ }^{16}$ and the development of lumbering and shipbuilding industries. ${ }^{17}$ In addition, whaling has been demonstrated to have played a role in New England's economic development. ${ }^{18}$ In all these ways and more, the sea contributed directly to New England's commercial expansion between the seventeenth and eighteenth centuries.

Burgeoning colonial maritime enterprises, as several scholars have suggested, posed a direct challenge to British authority during the Revolutionary Era. The literature on smuggling, or illicit trade, and imperial efforts to curtail these activities has been substantial and sophisticated. ${ }^{19}$ These works clearly demonstrate the contest of wills that existed between

Century (Cambridge, Mass.: Harvard University Press, 1955); and William T. Baxter, The House of Hancock: Business in Boston, 1724-1775 (Cambridge: Harvard University Press, 1945).

${ }^{15}$ Lisa Norling, Captain Ahab Had a Wife: New England Women and the Whalefishery, 1720-1870 (Chapel Hill, N.C.: University of North Carolina Press, 2000); Elaine Forman Crane, Ebb Tide in New England: Women, Seaports, and Social Change, 1630-1800 (Boston: Northeastern University Press, 1998). Also, see Alfred F. Young, "The Women of Boston: 'Persons of Consequence' in the Making of the American Revolution,” in Harriet B. Applewhite and Darline G. Levy, eds., Women \& Politics in the Age of the Democratic Revolution (The University of Michigan Press, 1990), 181-226.

${ }^{16}$ Daniel Vickers, Young Men and the Sea: Yankee Seafarers In the Age of Sail (New Haven, Conn.: Yale University Press, 2005); W. Jeffrey Bolster, Black Jacks: African American Seamen in the Age of Sail (Cambridge: Harvard University Press, 1997); Bailyn, Bernard and Lotte Bailyn, Massachusetts Shipping, 1697-1714: A Statistical Study (Cambridge: Harvard University Press, 1959).

${ }^{17}$ Charles E. Clark, The Eastern Frontier: The Settlement of Northern New England, 1610-1763 (New York: Alfred A Knopf, 1970); Joseph A. Goldenberg, Shipbuilding In Colonial America (Charlottesville: Published for the Mariners Museum, Newport News, Virginia, by the University Press of Virginia, 1976); and Robert Greenhalgh Albion, Forests and Sea Power: The Timber Problem of the Royal Navy, 1652-1862 (Cambridge: Harvard University Press, 1926).

${ }^{18}$ Norling, Captain Ahab Had a Wife; Daniel Vickers, "Nantucket Whalemen in the Deep-Sea Fishery: The Changing Anatomy of an Early American Labor Force," Journal of American History, 72 (1985), 277-96; Richard C. Kugler, “The Whale Oil Trade, 1750-1775," in Seafaring In Colonial Massachusetts, 153-174; and Edouard A. Stackpole, The Sea Hunters: The New England Whalemen During Two Centuries, 1635-1835 (Philadelphia: J.B. Lippincott Company, 1953).

${ }^{19}$ Conrad Edick Wright and Katheryn P. Viens, eds., Entrepreneurs: The Boston Business Community, 17001850 (Boston: Northeastern University Press, 1997); John W. Tyler, Smugglers \& Patriots: Boston Merchants and the Advent of the American Revolution (Boston: Northeastern University Press, 1986); Joseph R. Frese, S.J., "Smuggling, the Navy, and the Customs Service, 1763-1772," in Seafaring In Colonial Massachusetts, 199-214; Benjamin W. Labaree, Patriots and Partisans: The Merchants of Newburyport, 1764-1815 (New York: W.W. Norton \& Company, Inc., 1975); Thomas C. Barrow, Trade and Empire: The British Customs Service in Colonial America, 1660-1775 (Cambridge: Harvard University Press, 1967); Jack M. Sosin, Agents and Merchants: British 
entrepreneurial colonial merchants seeking the highest profits at the lowest cost irrespective of imperial boundaries and political leaders in the British state who wanted colonists to work solely for the good of the Empire.

What has not received sufficient attention is the fundamental role played by the commercial cod fishing industry in New England's maritime expansion. The cod fisheries brought great wealth to colonial New England. By 1770, 8\% of adult male workers in the region were employed in the fishing industry. At the same time, fish brought in $35 \%$ of the area's total annual export revenue, making it the single most lucrative trade good in the entire region. This employment and capital, in turn, had a "spread effect" on maritime New England, stimulating growth in overseas trade, shipbuilding, ship rigging, sail making, and waterfront business development. ${ }^{20}$ Such a relationship between the sea and commercial development is not unique to colonial New England. According to Mahan: "The due use and control of the sea is but one link in the chain of exchange by which wealth accumulates; but it is the central link, which lays under contribution other nations for the benefit of the one holding it, and which, history seems to assert, most surely of all gathers itself riches." ${ }^{21}$

Despite what could be considered the economic primacy of the New England fisheries, to date only two scholarly works, separated by almost one hundred years, have systematically treated the subject. Raymond McFarland's A History of the New England Fisheries, published in 1911, traced in broad terms the rise of the industry prior to the American Revolution, its

Colonial Policy and the Origins of the American Revolution, 1763-1775 (Lincoln, Nebraska: University of Nebraska Press, 1965); Oliver M. Dickerson, The Navigation Acts and the American Revolution (Philadelphia: University of Pennsylvania Press, 1954); Baxter, The House of Hancock; and Arthur Meier Schlesinger, The Colonial Merchants and the American Revolution, 1763-1776 (New York: Columbia University Press, 1918).

${ }^{20}$ See chapter two.

${ }^{21}$ Mahan, The Influence of Sea Power Upon History, 225-226. 
devolution as a result of the war, and its nineteenth century rebirth. ${ }^{22}$ More recently, Daniel

Vickers has compared and contrasted the evolution of labor processes involved with farming and commercial fishing in Essex County, Massachusetts. ${ }^{23}$ But these excellent works have not been able to convey the full and vital importance of commercial fishing to colonial New England. Nor do they adequately treat the critical relationship between the fishing industry and the American Revolution. ${ }^{24}$

The maritime dimensions of the American Revolution have also been underemphasized. For the most part, maritime historians interested in the Revolution have focused on naval activities that took place during the war years. ${ }^{25}$ These naval histories have especially emphasized the U.S. Navy's formation, command structure, and tactics. ${ }^{26}$ Naval historians have

${ }^{22}$ Raymond McFarland, A History of the New England Fisheries (New York: D. Appleton \& Company, 1911).

${ }^{23}$ Daniel Vickers, Farmers and Fisherman: Two Centuries of Work in Essex County, Massachusetts, 1630-1830 (Chapel Hill: The University of North Carolina Press, 1994). Harold Adams Innis also discussed the New England cod fishing industry in the elaboration of his staple thesis. See, Harold Adams Innis, The Codfisheries: The History of an International Economy (New Haven: Yale University Press, 1940). However, Innis' primary focus is on Newfoundland, not New England. James G. Lydon has explored the volume of the New England fish trade to Iberian ports in a series of articles: "Fish for Gold: The Massachusetts Fish Trade with Iberia, 1700-1773," The New England Quarterly, Vol.54, No.4 (Dec., 1981), 539-582; "North Shore Trade in the Early Eighteenth Century,” American Neptune, Vol. 28, (1968), 261-274; and "Fish and Flour for Gold: Southern Europe and the Colonial American Balance of Payments,” Business History Review, Vol. 39, (1965), 171-183.

${ }^{24}$ McFarland devotes only one chapter to the Revolution and Vickers only a few comments. Indeed, Vickers has recently asserted that "the locals" in colonial Marblehead, Massachusetts were "cautious about political engagement" and remained "more nervous about engaging in radical action" during the Revolution. See, Daniel Vickers, "Young Men and the Sea: Yankee Seafarers in the Age of Sail: A Roundtable Response," International Journal of Maritime History, Vol. 17, No. 2 (December, 2005), 365.

${ }^{25}$ Exceptions include Paul A. Gilje, Liberty on the Waterfront: American Maritime Culture in the Age of Revolution (Philadelphia: University of Pennsylvania Press, 2004); Peter Linebaugh and Marcus Rediker, The Many-Headed Hydra: Sailors, Slaves, Commoners, and the Hidden History of the Revolutionary Atlantic (Boston: Beacon Press, 2000); Jesse Lemisch, Jack Tar vs. John Bull: The Role of New York's Seamen in Precipitating the Revolution (New York: Garland Publishers, 1997); Neil R. Stout, The Royal Navy In America, 1760-1775: A Study of Enforcement of British Colonial Policy In the Era of the American Revolution (Annapolis, Maryland: Naval Institute Press, 1973); Arthur L. Jensen, The Maritime Commerce of Colonial Philadelphia (Madison: State Historical Society of Wisconsin for the Department of History, University of Wisconsin, 1963). Most of these otherwise excellent works do not address the commercial fishing industry in colonial America. Gilje does briefly discuss the industry, but it is not a point of emphasis.

${ }^{26}$ E. Gordon Bowen-Hassell, Dennis M. Conrad, and Mark L. Hayes, Sea Raiders of the American Revolution: the Continental Navy in European Waters (Washington: Naval Historical Center, Department of the Navy, 2003); Nathan Miller, Broadsides: The Age of Fighting Sail, 1775-1815 (New York: John Wiley \& Sons, Inc., 2000); James A. Lewis, Neptune's Militia: the Frigate South Carolina During the American Revolution (Kent, Ohio: Kent 
also concentrated on military leadership in a biographical mode. ${ }^{27}$ Recently, Richard Buel, Jr. has explored the significant impact the British Naval blockade had on the American economy, ${ }^{28}$ while scholars studying privateering, maritime prisoners of war, and the proceedings of Vice Admiralty courts have also focused on wartime events. ${ }^{29}$ These works largely overlook the fishing industry, and as a result the significant influence of New England maritime traditions on the war has been neglected. ${ }^{30}$ Such disregard has, for example, caused naval historian Frank C.

State University Press, 1999); Robert Gardiner, ed., Navies and the American Revolution, 1775-1783 (London: Chatham Publishing, in association with the National Maritime Museum, 1996); Chester G. Hearn, George Washington's Schooners: The First American Navy (Annapolis: Naval Institute Press, 1995); Nicholas Tracy, Navies, Deterrence, \& American Independence: Britain and Seapower in the 1760s and 1770s (Vancouver: University of British Columbia Press, 1988); Maritime Dimensions of the American Revolution (Washington, D.C.: Naval History Division, Department of the Navy, 1977) (author's note: this a thirty-six page pamphlet consisting of two short conference papers devoted to the U.S. Navy and three brief comments); William M. Fowler, Jr., Rebels Under Sail: The American Navy During the Revolution (New York: Charles Scribner’s Sons, 1976); Nathan Miller, Sea of Glory: A Naval History of the American Revolution (Charleston, South Carolina: The Nautical \& Aviation Publishing Company of America, 1974); William Bell Clark, George Washington's Navy: Being An Account of his Excellency's Fleet in New England (Baton Rouge: Louisiana State University Press, 1960); Gardner Weld Allen, A Naval History of the American Revolution, Vols. 1-2, (Boston: Houghton Mifflin Company, 1913); and Charles Oscar Paullin, The Navy of the American Revolution: Its Administration, Its Policy, and Its Achievements (Chicago: The Burrows Brothers, Co., 1906).

${ }^{27}$ See, for example, Charles E. Claghorn, Naval Officers of the American Revolution: A Concise Biographical Dictionary (Metuchen, N.J.: Scarecrow Press, 1988); Samuel Eliot Morison, John Paul Jones, A Sailor's Biography (Boston: Little, Brown and Company, 1959); William James Morgan, Captains to the Northward: The New England Captains in the Continental Navy (Barre, Mass.: Barre Gazette, 1959); William Bell Clark, Lambert Wickes, Sea Raider and Diplomat: The Story of A Naval Captain of the American Revolution (New Haven: Yale University Press, 1932); Dudley W. Knox, Naval Genius of George Washington (Boston: Printed by the Riverside Press for Houghton Mifflin Company, 1932); James L. Howard, Seth Harding, Mariner: A Naval Picture of the Revolution (New Haven: Yale University Press, 1930).

${ }^{28}$ Richard Buel, Jr., In Irons: Britain's Naval Supremacy and the American Revolutionary Economy (New Haven: Yale University Press, 1998). Also, see David Syrett, The Royal Navy In American Waters, 1775-1783 (Brookfield, Vt.: Gower, 1989). For the French Navy, see Jonathan R. Dull, The French Navy and American Independence: A Study of Arms and Diplomacy, 1774-1787 (Princeton, N.J.: Princeton University Press, 1975).

${ }^{29}$ See, Francis D. Cogliano, American Maritime Prisoners in the Revolutionary War: The Captivity of William Russell (Annapolis, MD: Naval Institute Press, 2001); Carl Ubbelohde, The Vice-Admiralty Courts and the American Revolution (Chapel Hill: University of North Carolina Press, 1960); Louis F. Middlebrook, Maritime Connecticut During the American Revolution, 1775-1783, Vols. 1-2, (Salem, Mass.: The Essex Institute, 1925); and Octavius Thorndike Howe, Beverly Privateers In The American Revolution (Cambridge, Mass.: John Wilson and Son, 1922).

${ }^{30}$ Roger Morriss provides a two-page introduction to "Colonial seafaring” in Gardiner, ed., Navies and the American Revolution, 1775-1783, 12-14. Morriss briefly acknowledges that fishing was part of the colonial maritime tradition (13), but the connections between the commercial fisheries and the Revolution are left unexplored. Such a cursory nod to the fishing industry is common among naval histories. 
Mevers to assert incorrectly that colonial Americans did not arm vessels for war prior to the Revolution. $^{31}$

The scholarly neglect of the relationship between colonial maritime life and the Revolution can be attributed to a "terra-centric" perspective on this formative event that discounts, or overlooks entirely, colonists' experience with the sea. ${ }^{32}$ Historians have overwhelmingly emphasized the roles farmers and land campaigns played in the Revolution. ${ }^{33}$ As a result, the dominant view of the Revolution includes men shivering at Valley Forge rather than on the decks of vessels such as the Pitt Packet crossing the North Atlantic seas. Isolated among inland farming communities, the land-based story goes, men only agreed to fight when British regulars trampled agricultural crops and threatened town meetings in 1775 . Moreover, men went home to plant crops in the spring and then to harvest in the fall, making them reluctant

\footnotetext{
${ }^{31}$ Frank C. Mevers, "Naval Policy of the Continental Congress," in Maritime Dimensions of the American Revolution, 3. Colonists armed vessels for war in the Battle for Louisburg in 1745 and during the Seven Years' War. See, Phillip Chadwick Foster Smith, “King George, The Massachusetts Province Ship, 1757-1763: A Survey,” in Seafaring In Colonial Massachusetts, 175-198; and Howard Millar Chapin, "New England Vessels in the Expedition Against Louisbourg, 1745,” New England Historic Genealogical Register, Vol. 77, No. 1 (January, 1923), 95-110. According to Smith: "The maintenance of armed vessels by the Provincial government was no innovation at the beginning of the French and Indian War, for in one form or another it had become an established, routine practice in wartime since King William's War at the end of the seventeenth century." Smith, "King George," 175. In Chapin's words: "The American Navy did not spring forth full-fledged at the outbreak of the Revolution, like Pallas Athene from the head of Zeus." See, Chapin, "New England Vessels in the Expedition Against Louisbourg, 1745,” 1.

${ }^{32}$ For more on the concept of "terra-centrism," see Marcus Rediker, "Toward a People's History of the Sea," in David Killingray, Margarette Lincoln, and Nigel Rigby, eds., Maritime Empires: British Imperial Maritime Trade in the Nineteenth Century (Rochester, NY: Boydell, in association with the National Maritime Museum, 2004), 195206.

${ }^{33}$ Examples of this terra-centric focus include: Don Higginbotham, War and Society in Revolutionary America: The Wider Dimensions of Conflict (Columbia, S.C.: University of South Carolina Press, 1988); Richard L. Bushman, King and People in Provincial Massachusetts (Chapel Hill: North Carolina University Press, 1985); E. Wayne Carp, To Starve the Army at Pleasure: Continental Army Administration and American Political Culture, 1775-1783 (Chapel Hill: University of North Carolina Press, 1984); Richard Buel, Jr., Dear Liberty: Connecticut's Mobilization for the Revolutionary War (Middletown, Conn.: Wesleyan University Press, 1980); John Shy, A People Numerous and Armed: Reflections on the Military Struggle for American Independence (Oxford: Oxford University Press, 1976); and Robert A. Gross, The Minutemen and Their World (New York: Hill and Wang, 1976). Typical of this view is Higginbotham, who discusses "the provincialism," "the rural isolation, the traditions of localism," that defined "a predominantly agrarian society." He also maintains "the War of Independence was for Americans mainly a defensive type of struggle waged on the patriots' soil." Soldiers in the Continental Army, we are told, "were mainly farmers, blacksmiths, tanners, and artisans." Higginbotham, War and Society in Revolutionary America, 7, 11, 12, 13, 21.
} 
part-time patriots. Such a portrait of the Revolution fails to capture the reality of an event that began primarily as a result of maritime disputes, that concerned thousands of laborers and merchants involved in maritime commerce, and that involved an empire held together chiefly by maritime power and communication.

This dissertation is the first full-length study of the relationship between New England's commercial cod fishing industry and the American Revolutionary War. I take a wide-ranging approach to explore this relationship. History from below, or history from "the bottom up," has shifted our understanding of the American Revolution away from an interpretive framework focused exclusively on wealthy white male Congressional authorities, military leaders, and Parliamentarians, and toward an inclusion of working peoples and minorities. ${ }^{34}$ This dissertation utilizes a bottom up approach to investigate the ways in which maritime laborers involved with the New England fishing industry directly contributed to the American war effort. ${ }^{35}$ Diaries, journals, merchant account books, newspapers, ship’s log books, and military service records help to recover this history from below.

\footnotetext{
${ }^{34}$ Alfred F. Young attributes this historical approach to Jesse Lemisch. Young, "An Outsider and the Progress of a Career in History,” William and Mary Quarterly, $3^{\text {rd }}$ Ser., Vol. 52, No. 3 (July, 1995), 505. Jesse Lemisch, "The American Revolution Seen from the Bottom Up," in Barton Bernstein, ed., Toward a New Past: Dissenting Essays in American History (New York, 1968), 3-45. History from below has influenced different sub-fields in history. Examples of "new" maritime history include Gilje, Liberty on the Waterfront; Linebaugh and Rediker, The Many-Headed Hydra; and Margaret S. Creighton and Lisa Norling, eds., Iron Men, Wooden Women: Gender and Seafaring in the Atlantic World, 1700-1920 (The John Hopkins University Press, 1996). For "new" military history, see Holly A. Mayer, Belonging to the Army: Camp Followers and Community during the American Revolution (Columbia, S.C.: University of South Carolina Press, 1996); and Charles Patrick Neimeyer, America Goes to War: A Social History of the Continental Army (New York University Press, 1996). For “new” social history, see Alfred F. Young, Liberty Tree: Ordinary People and the American Revolution (New York: New York University Press, 2006); Gary B. Nash, The Unknown American Revolution: The Unruly Birth of Democracy and the Struggle to Create America (New York: Viking, 2005); and Nancy L. Rhoden and Ian K. Steele, eds., The Human Tradition In the American Revolution (Wilmington, DE: Scholarly Resources Inc., 2000).

${ }^{35}$ For a path-breaking study linking labor and military histories in a study of the eighteenth-century British Army, see Peter Way, "Rebellion of the Regulars: Working Soldiers and the Mutiny of 1763-1764," The William and Mary Quarterly, $3^{\text {rd }}$ Series, Vol. 57, Issue 4 (October, 2000), 761-792.
} 
This dissertation is an example of Atlantic history, which has broadened our understanding of early America. ${ }^{36}$ It is no longer tenable to view colonial regions within a parochial vacuum or explain major events such as the Revolution solely through local, regional, or proto-national developments. I have relied on archival material from research institutions in the United States, Canada, and England in order to explore colonial New England's connection with the wider Atlantic world. Secondary works on the Caribbean, South America, Africa, and the Portuguese Atlantic islands helped to round-out these Atlantic connections.

The dissertation is conceptually divided into two parts, each in its own way addressing the why and how of the American Revolution. Chapters one and four examine how labor and capital in the fishing industry functioned, and how each contributed to the Revolutionary War. Chapters two and three focus on why members of the fishing industry, merchants and workers, were willing to resist British authority during the imperial crisis. The central argument is twofold: New England's maritime expansion provoked a series of prejudicial Parliamentary legislation in which the British state attempted to regulate colonial overseas commerce, all of which helps to explain why the Revolution began in New England and why a majority of the men who fought in the war called this region home. The second part of the argument is that the nature of work in the commercial cod fishing industry uniquely prepared fishermen and fish merchants to play leading roles in securing American independence. The dissertation reveals a

\footnotetext{
${ }^{36}$ Accounts of the rise of Atlantic history can be found in Bernard Bailyn, Atlantic History: Concept and Contours (Cambridge, MA: Harvard University Press, 2005); Elizabeth Mancke and Carole Shammas, eds., The Creation of the British Atlantic World (Baltimore: The Johns Hopkins University Press, 2005), esp. the introduction by Carole Shammas, 1-16; David Armitage, "Three Concepts of Atlantic History," in David Armitage and Michael Braddick, eds., The British Atlantic World, 1500-1800 (London: Palgrave, 2002), 11-27, 250-254; Nicholas Canny, "Atlantic History: What and Why?" European Review, Vol. 9, No.4 (2001): 399-411; Linebaugh and Rediker, The Many-Headed Hydra; and Alan L. Karras, "The Atlantic World as a Unit of Study," and J.R. McNeill, "The End of the Old Atlantic World: America, Africa, Europe, 1770-1888," both in Karras and McNeill, eds., Atlantic American Societies (London: Routledge, 1992), 1-15 and 245-268.
} 
deep historical relationship between the world of commerce and the way of war. It moors the American Revolution in maritime history.

John Adams long ago recognized the importance of studying the maritime dimensions of the American Revolution. Having succeeded in getting the charges against the Marblehead mariners dropped in 1769, Adams believed this legal victory, this resistance, and the impressment behind both, to be more significant in stirring popular sentiment for the cause of independence than the trials surrounding the Boston Massacre, in which he defended the British soldiers. Adams would later write to a friend, "Panton and Corbet ought not to have been forgotten,” adding, "Preston and his soldiers ought to have been forgotten sooner.”37

${ }^{37}$ Charles Francis Adams, The Works of John Adams, Second President of the United States, Vol. 10, (Boston: Little, Brown and Company, 1856), 210. 


\title{
2.0 THE NATURE OF WORK IN THE EIGHTEENTH CENTURY MASSACHUSETTS COD FISHING INDUSTRY
}

\begin{abstract}
"It is known to be one of the most laborious employments; that those who carry it on get to themselves but a bare subsistence..." "Montesquieu," on "The profits accruing to the [eighteenth century Massachusetts] fishery," Boston Evening Post, November 28, 1763.
\end{abstract}

In the summer of 1774, Joshua Burnham, George Pierce, Stephen Low, James Andrews, Samuel Burnham, Daniel Andrews, and Peter Edwards left Ipswich, Massachusetts in the schooner Polly on a commercial fishing expedition, or "fare," to the Grand Bank off Newfoundland. ${ }^{1}$ Their vessel, like most others operating in the New England cod fishing industry at this point, was a schooner. The size of their crew was normal. The home port, Ipswich, was similar to other North Shore Massachusetts fishing ports in that it had expanded its commercial activities during the middle of the eighteenth century, and the destination would not have been unusual at all for commercial fishermen on the eve of the American Revolution. ${ }^{2}$ In many ways, the Polly's fare was typical for the period. Following the crew through their experiences will therefore enable us to glimpse what it was like to live and work in one of colonial Massachusetts' oldest, most labor intensive, and most lucrative industries.

\footnotetext{
${ }^{1}$ Joshua Burnham Papers, 1758-1817, Box 1, Shipping Papers, Schooner Polly, 1771-1776, Folder 4, JDPL.

${ }^{2}$ See, Daniel Vickers, Farmers and Fishermen: Two Centuries of Work in Essex County, Massachusetts, 16301830 (Chapel Hill: The University of North Carolina Press, 1994).
} 


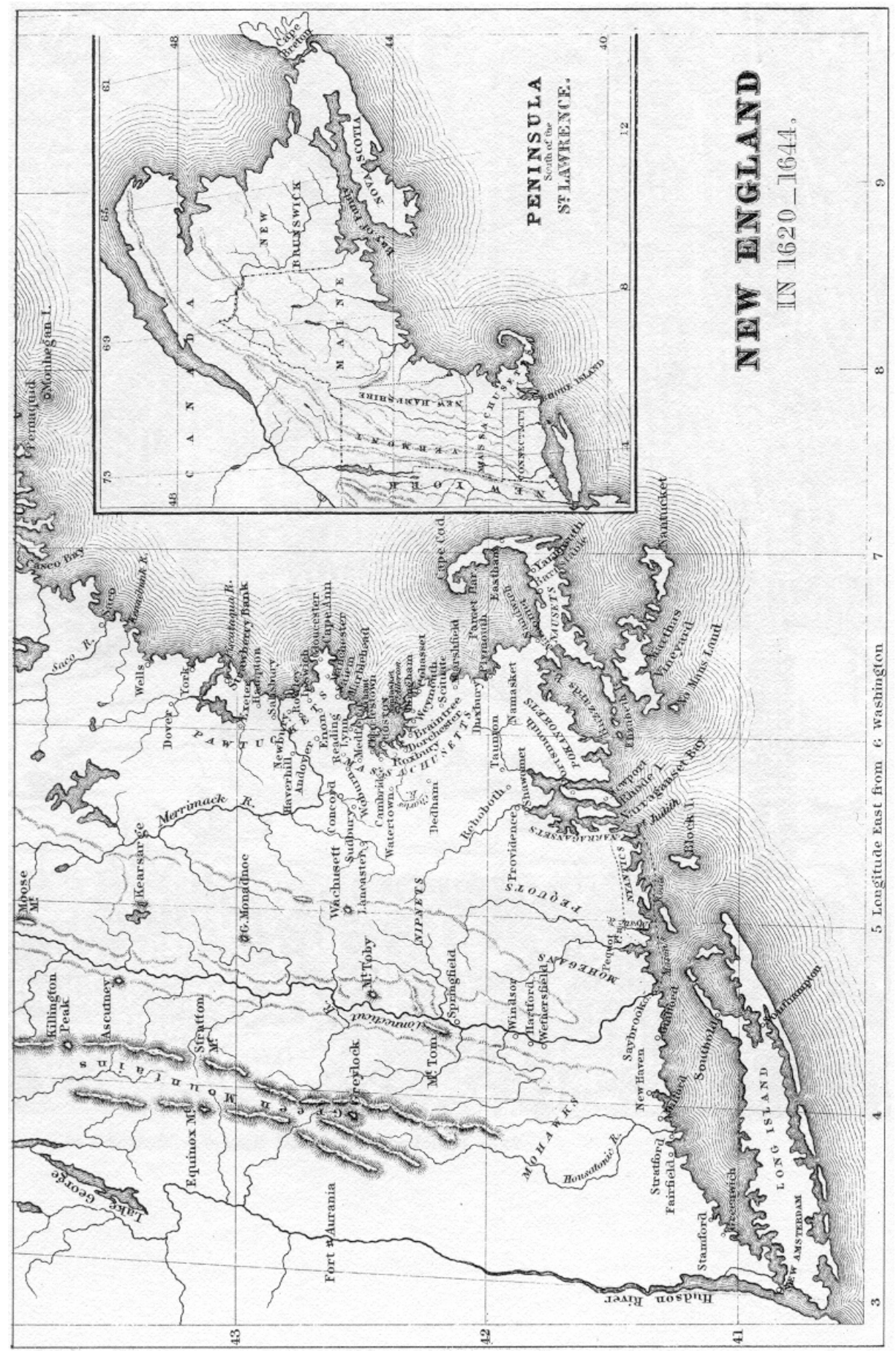

Figure 1: 17th century New England towns. ${ }^{3}$

\footnotetext{
${ }^{3}$ Bernard Bailyn, The New England Merchants in the Seventeenth Century, 3rd ed., (Cambridge: Harvard University Press, 1995), 130.
} 
A significant portion of New England's population worked in the cod fishing industry. Of the 581,100 people living in New England in $1770,10,000$ - or $7.8 \%$ - of the adult male working population found employment in this sector of the economy. ${ }^{4}$ In 1765 , there were 4,405 workers employed in the Massachusetts cod fisheries, $8.1 \%$ of the 245,698 people counted in the colony's census. ${ }^{5}$ Their labors remained vital to the economic development of the entire New England region.

Cod was king in late eighteenth-century New England. Between 1768 and 1772, fish represented 35\% of the region's total export revenue, making it the single most valuable export for this section of the British North American colonies at this time. ${ }^{6}$ Massachusetts was the site of the principal fishing ports and shipping centers in the region throughout the colonial period (See Figure 1). Its coastal communities were responsible for shipping $99.5 \%$ of the total quintals (112 lbs. dry weight; pronounced "kentals") of cod exported to Southern Europe and the Wine Islands between 1771 and 1772 . The same ports were responsible for shipping $44.8 \%$ of the total quintals of cod to the West Indies during this period. Combined, Massachusetts ports shipped

\footnotetext{
${ }^{4}$ For the number of workers, see Robert G. Albion, William A. Baker and Benjamin W. Labaree, New England and the Sea (Mystic, Connecticut: Mystic Seaport Museum, Inc., 1972), 29-30. One contemporary estimate placed the number of workers "employ'd in the Cod fishery" as high as 13,000. Boston Evening Post, January 20, 1766. For the population figure, see John J. McCusker and Russell R. Menard, The Economy of British America, 16071789 (Chapel Hill, North Carolina: The University of North Carolina Press, 1985), 103, Table 5.1. The 8\% calculation was made following Vicker's method of first factoring a 55\% male population and then factoring a $40 \%$ demographic of men aged 15-45: "the male working population." Vickers, Farmers and Fishermen, 194n.

${ }^{5}$ For the size of the workforce, see Thomas Jefferson, Secretary of State, Report on the State of the Cod Fisheries, 1791, American State Papers: Commerce and Navigation, I:13, Table 2. For the population figure, see Robert V. Wells, The Population of the British Colonies in America before 1776: A Survey of Census Data (Princeton, New Jersey: Princeton University Press, 1975), 79.

${ }^{6}$ The second most valuable export commodity, livestock, represented only $20 \%$ of this revenue stream. McCusker and Menard, The Economy of British America, 1607-1789, 108, Table 5.2. New England fish ranked sixth in terms of the value of British North American and Caribbean exports, 1764-1775, behind sugar products, tobacco, Newfoundland fish, bread and flour, and rice, in that order. See, Stephen J. Hornsby, British Atlantic, American Frontier: Spaces of Power In Early Modern British America (Hanover: University Press of New England, 2005), 26-28, esp. Figure 2.1.
} 
$85.2 \%$ of all the fish caught in the colonies in the early 1770 s. $^{7}$ By themselves, Marblehead and Gloucester, Massachusetts accounted for $60 \%$ of all the fish caught annually in the entire New England region. ${ }^{8}$ Although there were certainly commercial fisheries in other colonies, none were as extensive or commercially significant as those in Massachusetts. The expansion of labor and capital in the fishing industry also had a "spread effect" encouraging the development of other sectors of the domestic economy, especially lumbering, shipbuilding, and ship rigging, but also farming. ${ }^{9}$ In this way, the work of eighteenth-century Massachusetts fishermen was important to the economy of much of New England.

Despite the centrality of labor in the cod fishing industry to New England's economic development, scholarship on the subject has been limited. Almost a century ago, Raymond McFarland described eighteenth-century fishermen as deep-sea workers, employed year-round "on their own hook," or, on a count system whereby men were paid for the number of fish they

${ }^{7}$ British North American Customs Papers, 1765-1774, MHS.

${ }^{8}$ Albion, Baker and Labaree, New England and the Sea, 30. Because the Massachusetts fishing industry took such a majority of the share of the catch from the entire region, and maintained such a large proportion of fishermen and fishing vessels, Daniel Vickers has gone so far as to assert that during the colonial period the New England and Massachusetts fishing industries "can be treated as roughly equivalent." Vickers, Farmers and Fishermen, 154, Table 4.

${ }^{9}$ For more on the economic concept of "spread effects," see McCusker and Menard, The Economy of British America, 1607-1789, 23. Threatened by the loss of the fishing industry during the American Revolution, a Boston town meeting resolved: "It is hence also easy to conceive (though we apprehend needless to urge) of how vast an importance the preservation of this trade is to every other part of the Commonwealth [the "Federal Republic" of the United States]. The various mechanics, necessarily employed in the building, rigging and fitting out such a number of vessels, must without it be destitute of subsistence. And the great quantities of provisions, expended by our fishermen, and the timber made use of in building the vessels, together with the staves, hoops, \&c. made use of in the exportation of the fish and oil, will convince us that the loss of the Fishery must essentially affect our inland brethren.” Gentlemen, the inhabitants of the town of Boston... (Boston: Benjamin Edes and Sons, 1781), Early American Imprints, Series I: Evans \#17105. For more on the cod fishing industry’s spread effect in colonial Massachusetts, see Daniel Vickers, Young Men and the Sea: Yankee Seafarers In the Age of Sail (New Haven, Conn.: Yale University Press, 2005); and Farmers and Fishermen. Commercial fishing had similar effects around the early modern Atlantic world. See, Peter E. Pope, Fish Into Wine: The Newfoundland Plantation in the Seventeenth Century (Chapel Hill: The University of North Carolina Press, 2004); David J. Starkey, Chris Reid, and Neil Ashcroft, eds., England's Sea Fisheries: The Commercial Sea Fisheries of England and Wales since 1300 (London: Chatham Publishing, 2000); and Jan De Vries and Ad Van Der Woude, The First Modern Economy: Success, Failure, and Perseverance of the Dutch Economy, 1500-1815 (Cambridge: Cambridge University Press, 1997), 267-268. 
caught. ${ }^{10}$ More recently, Daniel Vickers has provided an in-depth examination of life and work in the colonial Massachusetts fishing industry. He agrees with McFarland that by the opening decades of the eighteenth century fishermen were operating in deep-sea vessels off the Northeastern shoreline of North America and the coast of Newfoundland. His social history goes far beyond McFarland's broad overview, however. For Vickers, being a fisherman meant hard manual labor and chronic debt through one's teenage years, into one’s twenties. Some men "used an apprenticeship in the fishery as a springboard into a seafaring career." But the "majority" of fishermen labored into their early thirties, "relinquished their berths to younger men," and then "some floated into the merchant marine and managed to eke out a living for a few years as common seamen."11

\footnotetext{
${ }^{10}$ Raymond McFarland, A History of the New England Fisheries (New York: D. Appleton \& Company, publishers for the University of Pennsylvania, 1911), 96-97.

${ }^{11}$ Vickers, Farmers and Fishermen, ch. 4, esp. 150-151, and 167-191. Quotes taken from 149-150, 184. This chapter owes much to Daniel Vickers' written work and his useful advice. For works that discuss the colonial New England cod fishing industry but do not focus on the subject, or spend much time on the fishermen and the labor process involved in commercial fishing, see Hornsby, British Atlantic, American Frontier; Deborah C. Trefts, "Canadian and American Poliy Making in Response to the First Multi-Species Fisheries Crisis in the Greater Gulf of Maine Region,” in Stephen J. Hornsby and John G. Reid, eds., New England and the Maritime Provinces: Connections and Comparisons (Montreal: McGill-Queen’s University Press, 2005), 206-231, esp. 206-217; Pope, Fish Into Wine; Phyllis Whitman Hunter, Purchasing Identity in the Atlantic World: Massachusetts Merchants, 1670-1780 (Ithaca, NY: Cornell University Press, 2001); Benjamin W. Labaree, William M. Fowler, Edward W. Sloan, John B. Hattendorf, Jeffrey J. Safford, and Andrew W. German, America and the Sea: A Maritime History (Mystic, Conn.: Mystic Seaport Museum Publications, 1998); Mark Kurlansky, Cod: A Biography of the Fish That Changed the World (Toronto: Alfred A. Knopf Canada, 1997); Faith Harrington, "“Wee Tooke Great Store of Codfish': Fishing Ships and First Settlements on the Coast of New England, 1600-1630,” in Emerson W. Baker, et al., eds., American Beginnings: Exploration, Culture, and Cartography in the Land of Norumbega (Lincoln: University of Nebraska Press, 1994), 191-216; D. W. Meinig, The Shaping of America: A Geographical Perspective On 500 Years of History, Volume 1, Atlantic America, 1492-1800 (New Haven: Yale University Press, 1986); Alaric Faulkner, "Archeology of the Cod Fishery: Damariscove Island," Historical Archeology, Vol. 19, No. 2 (1985), 5786; Christine Leigh Heyrman, Commerce and Culture: The Maritime Communities of Colonial Massachusetts, 1690-1750 (New York: W.W. Norton \& Company, 1984); Douglas R. McManis, Colonial New England: A Historical Geography (New York: Oxford University Press, 1975); George A. Rawlyk, Nova Scotia's Massachusetts: A Study of Massachusetts-Nova Scotia Relations, 1630-1784 (Montreal: McGill-Queen’s University Press, 1973); Albion, Baker and Labaree, New England and the Sea; Charles E. Clark, The Eastern Frontier: The Settlement of Northern New England, 1610-1763 (New York: Alfred A Knopf, 1970); Bailyn, The New England Merchants in the Seventeenth Century; William T. Baxter, The House of Hancock: Business in Boston, 1724-1775 (Cambridge: Harvard University Press, 1945); Harold Adams Innis, The Codfisheries: The History of an International Economy (New Haven: Yale University Press, 1940); Richard A. Preston, "Fishing and Plantation: New England in the Parliament of 1621,” The American Historical Review, Vol. 45, No. 1 (October, 1939), 29-43;
} 
As useful as both of these works are, they have limitations. Both scholars largely confine their discussions to labor on off-shore banks. There is also a tendency to homogenize the crew, that is, to see all the men above the cuttail rank as roughly the same. ${ }^{12}$ There is one category for skilled fishermen, just as there has only been one definition of fishermen, and everyone old enough and experienced enough has been placed into this category. ${ }^{13}$ Vickers, for example, sees little difference between skippers and the other sharesmen in fishing crews. He writes, "the skipper was merely the first among equals. Like his mates, he took a turn at the helm, hauled on the sheets, and tended his lines, and at the end of the voyage he was paid on exactly the same terms they were.” Vickers further asserts that a fishing skipper lacked the legal authority to beat his crew, while the master of a merchant vessel was so empowered. ${ }^{14}$ In this interpretation the divisions between a skipper and his crew were not as rigid as they were between a master and his mariners. ${ }^{15}$ This chapter explores the issue in depth.

Restricting our interpretation of eighteenth-century fishermen to deep-sea hand-liners of cod does not fully capture what it meant to live and work in this vital and vibrant industry. Viewing Massachusetts fishermen in this way cannot account for the fact that these men

Ralph Greenlee Lounsbury, The British Fishery at Newfoundland 1634-1763 (New Haven, CT: Yale University Press, 1934); Charles Judah, The North American Fisheries and British Policy to 1713 (Urbana, IL: University of Illinois Press, 1933); Samuel E. Morison, Maritime History of Massachusetts, 1783-1860 (Boston: Houghton Mifflin, 1921); and Arthur Meier Schlesinger, The Colonial Merchants and the American Revolution, 1763-1776 (New York: Columbia University Press, 1918). Also, see Faith Harrington, "Sea Tenure In Seventeenth Century New England: Native Americans and Englishmen In the Sphere of Marine Resources, 1600-1630,” (Ph.D. Dissertation, University of California, Berkeley, 1985); and Edwin A. Churchill, "Too Great the Challenge: The Birth and Death of Falmouth, Maine, 1624-1676,” (Ph.D. Dissertation, University of Maine, 1979).

${ }^{12}$ The term "cuttail" referred to a younger worker in the fishing industry below the rank of sharesman. There were usually four cuttails on each fishing fare: the "single;" "double;" "swallow;" and "stump." These terms pertained to the markings each worker made on the tails of the fish in order to indicate the number they caught. The names for each cuttail can be found in the merchant account books described below in footnotes 34-43.

${ }^{13}$ The term "skilled" fisherman is used here and throughout to refer to the skipper of a fishing vessel and the sharesmen, the older, more experienced hands who earned a share of the profits from the sale of the catch.

${ }^{14}$ Vickers, Farmers and Fishermen, 151, and footnote \#12 on 152.

${ }^{15}$ Vickers has complicated this picture in his latest work by arguing that the master's legal authority on merchant vessels was greatly mitigated by kinship ties, community relations, and sea-borne camaraderie. See, Vickers, Young Men and the Sea, 90-95 and ch.7. 
commonly worked as merchant mariners, or tars, and day laborers while they were employed in the fishing industry. Nor can dissolving or minimizing the boundaries between skippers, sharesmen, and cuttails get us close enough to the nature of ship life in the fishing industry. If divisions did not exist among fishing crews, and if men received no extra earnings and no additional authority, then it is not clear why anyone would have chosen to take on the additional responsibilities associated with being a skipper, including being held personally accountable for assembling the crew, choosing the location of fishing, handling the vessel in rough seas, and keeping count of each cuttails' catch of fish in addition to the total fish count for the vessel. Men did not simply use the fishing industry as a "springboard," and they did not just rely on the merchant service as a "safety net” to fall back on upon retirement from fishing. The eighteenthcentury commercial fishing industry in Massachusetts operated on a vernacular basis in which occupational identities were multi-functional. ${ }^{16}$

This chapter will broaden the definition of an eighteenth century Massachusetts fisherman to include forms of labor associated with the commercial fishing industry beyond deep-sea handling for cod. Shifting our focus in this way makes it possible to develop a definition for an eighteenth-century fisherman that encompasses his full working experience. Only then is it possible to determine what it was like to work in this important industry and why men would want to become a skipper.

\footnotetext{
${ }^{16}$ Pope has drawn a distinction between early modern "vernacular” and “directed” industries. On a continuum, vernacular industries represent locally defined enterprises guided by customs at one end of the spectrum. A directed industry "is conceived, often by a board of directors, before it physically exists and is a project, closely controlled in many particulars, not by custom, but by directive. The ability to transmit information as text using standardized terms is decisive." While his efforts are specifically aimed at understanding the commercial fishing industry in seventeenth century Newfoundland, he maintains the generality of this analytic model. He writes, "the vernaculardirected distinction...is, in fact, intended to address some of the analytic shortcomings of 'merchant capitalism' as an adequate description of the economic context of early modern industry.” Pope, Fish Into Wine, 30-31. Here, the term vernacular industry is used to reflect the fact that the eighteenth-century commercial fishing industry in Massachusetts was not completely standardized in terms of occupational identities or structural organization.
} 
Ideally, there would be extensive first-hand evidence in which eighteenth-century fishermen discussed and defined the nature of their own work. Yet, few writings of literate laborers have survived the centuries, and these only provide sparse, anecdotal primary evidence. Christopher Prince, for example, was born in Kingston, Massachusetts, in 1751, and went deepsea hand-lining for cod at the age of thirteen, "though I was young and small, too much so to catch fish and lift them out of the water on deck, which my father knew I was unable to do.”17 Between 1764 and 1765 Prince worked with a total of two fishing crews on an unspecified number of fares. He described the work as very physically demanding, "the most trying of any employment," and the work culture as decidedly irreligious, or "profane.”18 After a brief stint in fishing vessels, Prince switched to the merchant marine. Ashley Bowen was born in Marblehead, Massachusetts in 1728, and labored on and off in the fishing industry from 1739 to 1763. During this time he went to sea with fishing crews and brought back catches, and he sought berths on merchant vessels freighting fish and other goods around the Atlantic world. ${ }^{19}$ Bowen never detailed the labor involved, and said little about how it felt to be a member of the fishing industry, to join a crew, and to hand-line for cod on the Atlantic Ocean, although his work in the eighteenth-century Massachusetts commercial fishing industry took him through a range of experiences. Benjamin Bangs' diary paints a similar picture. He was born in Harwich, Massachusetts on Cape Cod in 1721. His father worked as a fisherman and owned a small farm and tanyard. Young Bangs went on cod fishing expeditions between 1743 and 1746. During this time, he supplemented his income in the fishing industry by teaching "young Rogues" in a local

\footnotetext{
${ }^{17}$ Michael J. Crawford, ed., The Autobiography of A Yankee Mariner: Christopher Prince and the American Revolution (Washington, D.C.: Brassey’s, Inc., 2002), 11-18. Quote taken from 13.

${ }^{18}$ Crawford, ed., The Autobiography of A Yankee Mariner, 16.

${ }^{19}$ Phillip Chadwick Foster Smith, ed., The Journals of Ashley Bowen (1728-1813), Vol.1, (Portland, Maine: The Colonial Society of Massachusetts, 1973), 7-137. For more on Bowen's sailing career, see Vickers, Young Men and the Sea, 96-105, esp. Table 4.1. Also, see Daniel Vickers, “An Honest Tar: Ashley Bowen of Marblehead,” New England Quarterly, Vol. 69, No. 4 (December, 1996), 531-53.
} 
school. Bangs also fished for mackerel, haddock, and even whales. In addition, he helped his father run the six-acre family farm, which maintained a flock of sheep and produced corn and hay. ${ }^{20}$ Like Bowen and Prince, Bangs did not describe his experience as a fisherman in great detail, and none of these men made commercial fishing life-long careers. For Bowen and Bangs, work in the fishing industry routinely involved other types of labor and a variety of experiences. They were not alone in this respect.

It is possible to supplement these scant first-hand accounts through an examination of merchant's account books, shipping papers, log books, and newspapers. Merchants involved in the commercial fishing industry scrupulously recorded their employees' names and their labor activities for a given year, in addition to the types and amounts of goods they purchased. These records enabled merchants to keep track of worker's earnings, productivity, and debts. They provide us with crew lists, earnings, debt, promotion rates, catch sizes, fish prices, capital outlays, food and drink consumed, duration of time at sea, length of employment, types of employment and kinship ties. The shipping papers compliment the ledgers by providing crew lists, cargoes, destinations, and wages for vessels engaged in overseas trade affiliated with the industry. This information deepens our understanding of what sorts of activities men accomplished on a yearly basis in the fishing industry for the same employers. Precious few log books for eighteenth century fishing schooners have survived the ravages of time. ${ }^{21}$ Yet those few that do remain enable us to trace routes fishermen used, weather they experienced, the time involved in travel and fishing, depths in which they fished, vessels "spoke" with, and the amount of fish they caught. In addition, colonial newspapers printed accounts of work-related injuries

\footnotetext{
${ }^{20}$ Benjamin Bangs Diary, 1742-1765, MHS.

${ }^{21}$ Of the 3,000 log books housed at the JDPL, only three pertain to eighteenth century fishing vessels. The MHS also maintains a small collection. There is one held at the MHDHS.
} 
and deaths associated with the commercial fishing industry. In short, despite the dearth of firsthand accounts it is possible to piece together the work experience of eighteenth-century cod fishermen in the colony where Joshua Burnham lived.

\subsection{TRANSITION}

There were marked differences in the commercial cod fishing industry in colonial Massachusetts between the seventeenth and the eighteenth centuries. ${ }^{22}$ For much of the earlier era, the industry was prosecuted on an inshore, as opposed to offshore, basis. ${ }^{23}$ Smaller, three-man crews, consisting of a foreshipman, midshipman, and steersman, worked close to shore and near home ports in shallops. Vessel ownership was widespread. Fishermen tended to be foreign-born, and they frequently contracted heavy and long term debts as a result of the loose credit terms merchants offered in order to attract workers in a scarce labor market.

In the eighteenth century, by contrast, most commercial fishermen headed to offshore banks to ply their trade. Seven-to-eight-man crews worked on schooners far from home. At the top of the labor hierarchy sat the skipper. He was responsible for recruiting crews, choosing where to fish, navigating the vessel, fishing, and keeping a count of the fish caught. ${ }^{24}$ The sharesmen were the older, more experienced hands on board the schooner. Their primary duties revolved around handlining for cod and helping to process the catch. The cuttails were the

\footnotetext{
${ }^{22}$ The following discussion leans heavily on Vickers, Farmers and Fishermen, chapters 3 and 4, esp. pgs. 122126 and 146-167.

${ }^{23}$ Pope provides a concise definition of these two fisheries: "Inshore fisheries are prosecuted from shore in dayto-day voyages by open boats on fishing grounds close to the coast; offshore fisheries are prosecuted from ships voyaging for weeks at a time to fishing banks, which may be days or even weeks sailing from land.” Pope, Fish Into Wine, 14.

${ }^{24}$ These duties will be described in detail in subsequent sections.
} 
younger, inexperienced greenhands. They were mainly responsible for cutting bait, baiting hooks, and processing the catch, although they did help out with fishing. Vessel ownership had contracted, and very few workers owned even a share of the schooner on which they went to sea. During this era, fishermen tended to be born locally. And while these workers still went into debt, merchants had tightened the credit terms as a result of large local labor pools and the availability of labor.

\subsection{LABOR RECRUITMENT}

Burnham (1736-1791) was skipper of the schooner Polly in 1774. He and his younger brother Aaron were sons of Jeremiah Burnham, a middling farmer and part-owner of a sawmill in the Cape Anne parish of Chebacco, near Gloucester. Aaron fished commercially until he was forty years old, when his clothes and part of the vessel he was working on washed up on shore in 1782. For his part, Joshua fished and mastered at least twelve vessels for various Massachusetts merchants between 1761 and 1790 . Like so many other workers in the colonial fishing industry, he died "sick from the West Indies." 25

As a skipper, it was primarily Burnham’s responsibility to recruit a crew, or “company,”

for the fishing fare. ${ }^{26}$ While it was theoretically possible for him to have chosen women, older men, African-Americans, and Native-Americans who lived in the area, Burnham chose none of these people and he was not alone in his recruiting decisions. In the eighteenth-century, skippers

\footnotetext{
${ }^{25}$ Joshua Burnham Papers, 1758-1817, JDPL. EVREC, Vols. 1-2, 61, 505, 506. Vickers, Farmers and Fishermen, 200-201, 265.

${ }^{26}$ See, "Petition of the Selectmen of Marblehead [To Governor Francis Bernard and the Massachusetts General Court] asking for the passage of an act relating to the Cod-fishery, with a copy of said act," 1768, MSA Collections, Vol. 66, Maritime, 1759-1775, 406-409.
} 
ordinarily recruited white, young men for the work of deep-sea fishing. ${ }^{27}$ At this time, female settlers in Newfoundland were mobilized for shore duty, drying and processing catches. ${ }^{28}$ Female labor was certainly available in colonial Massachusetts, but women were not to be found at sea or on land engaged in the fishing industry in any capacity. Demographic factors such as natural increase, marriage rates, and family size may have contributed to the formation of prohibitive gender norms in Massachusetts by the eighteenth century, when off-shore fishing relocated shore work to port towns. By contrast, maintaining a stable population in Newfoundland proved problematic, and women only began coming to Newfoundland in significant numbers around the time residents developed an off-shore fishery in the first half of the eighteenth century. Thus, there may have been few gender norms in place on this northern island when demand increased for domestic shore work.

Race also seems to have been a factor in determining who worked in the commercial cod fishing industry. There is very little evidence of African-American participation and nothing on Native Americans. By contrast, Native-Americans and African-Americans were actively involved in the colonial whaling industry throughout the eighteenth century, although in diminishing numbers over time. Their presence in this maritime occupation was stimulated by the chronic labor shortage the whaling industry faced. Given a choice between work hand-lining

\footnotetext{
${ }^{27}$ Vickers, Farmers and Fishermen, 173-176; and W. Gordon Handcock, Soe longe as there comes noe women: Origins of English Settlement in Newfoundland (St. Johns, Newfoundland: Breakwater Books, 1989), 40, 60-64.

${ }^{28}$ Handcock, Soe longe as there comes noe women, 31-32; and C. Grant Head, Eighteenth Century Newfoundland (Toronto: McClelland and Stewart Limited, 1976), 218, 232. For the use of female labor in seventeenth century Newfoundland, see Pope, Fish Into Wine, 56-57. More work needs to be done on the role gender norms played in the colonial cod fishing industry to explain why female labor was not mobilized in New England to the extent to which it was in Newfoundland.
} 
for cod from a large schooner and chasing whales with a harpoon in a small boat across the Atlantic Ocean, most Europeans chose life and work in the former. ${ }^{29}$

Age also affected labor recruitment. Throughout the colonial period, commercial cod fishermen tended to be younger workers between the ages of ten and thirty. ${ }^{30}$ A major reason why, soon to be explained in detail, was that the work of cod fishing proved physically very demanding. Moreover, employers typically saw diminishing returns on the productive capabilities of older hands past the age of thirty. ${ }^{31}$ The nature of the work, and the demands of productivity, made the eighteenth-century New England cod fishing industry concentrate on youth.

Kinship ties, it has been argued, played a decisive role in recruitment for the fishing industry. ${ }^{32}$ Yet, Joshua Burnham took only one of his family relations, Samuel, on the summer fare in 1774, and as a labor recruiter, he was not alone in this decision. The familial bonds between vessel-owning merchants, who played limited roles in labor recruitment, and crewmembers on fishing vessels were particularly weak. ${ }^{33}$ First, we will look at those occasions

\footnotetext{
${ }^{29}$ Daniel Vickers, "Nantucket Whalemen in the Deep-Sea Fishery: The Changing Anatomy of an Early American Labor Force,” The Journal of American History, Vol. 72, No. 2. (September, 1985), 290-292. I am grateful to Professor Vickers for bringing this article to my attention. He notes that the ability of minorities to obtain work in the whaling industry weakened over the course of the eighteenth century, as increased earning potential attracted more and more white laborers. Yet, minorities remained part of the workforce in the whaling industry. It will be discussed later that those few African Americans who did work in the cod fisheries faced more pressures than any of their fellow workers.

${ }^{30}$ Pope, Fish Into Wine, 172; Handcock, Soe longe as there comes noe women, 243-248, esp. Table 11.1; and Vickers, Farmers and Fishermen, 182-185, esp. Table 7.

${ }^{31}$ Vickers, Farmers and Fishermen, 179-180, esp. Figure 2.

${ }^{32}$ Vickers, Farmers and Fishermen, 165-167, 196. Vickers has also stressed the important role kinship ties played in labor recruitment in colonial Salem's merchant marine. See, Vickers, Young Men and the Sea, 78-79.

${ }^{33}$ What follows is an examination of three databases compiled by examining the ledger books of merchants involved in the commercial fishing industry. In order to evaluate kinship ties between vessel owners and all workers, I first counted every record in which a laborer worked for a particular vessel owner. Included here are partial crew lists, skippers, and crewmembers. Thus, the total data set was the largest (2,114 possible berths). I then searched for instances in which worker's surnames matched the vessel owner's surnames. Servants and slaves were not calculated as kin in any of the databases.

Certain limitations complicate this data. It may have been possible for some of the workers in these data sets to have had extended family relations, including nephews or cousins, with alternate surnames. However, in the one
} 
when some berths were filled by the vessel-owner's relatives. Of the 214 instances in which fishermen went to sea for William Knight of Marblehead between 1767 and 1775, workers shared the owner's surname on forty-four occasions, or $20.6 \%$ of the time. ${ }^{34}$ Of the 280 instances in which fishermen went to sea for Thomas Pedrick of Marblehead between 1760 and 1774, workers shared the owner's surname on fourteen occasions, or $5 \%$ of the time. ${ }^{35}$ Similarly, of the 185 instances in which fishermen went to sea for Richard Pedrick of Marblehead between 1766 and 1774, workers shared the owner's surname on four occasions, or $2.2 \%$ of the time. ${ }^{36}$ Also, of the 79 instances in which workers went to sea for Francis and John Choat of Ipswich between 1768 and 1777, workers shared the owner's surname on only two occasions, or $2.5 \%$ of the time. ${ }^{37}$ In aggregate, among the 758 berths, only 64 , or $8.4 \%$, were occupied by workers sharing the vessel owner's surname.

On many vessels there were no kin relations between owner and crew. There were no Choats in Burnham's company in the summer of 1774, and this was not unusual. Of the 527 instances in which fishermen went to sea for Daniel Rogers of Gloucester between 1770 and 1790, none were related to the owner. ${ }^{38}$ Of the 259 instances in which fishermen went to sea for

instance in which Vickers painstakingly measured these extended kinship ties and combined them with surnames for William Knight of Marblehead, he found that $55 \%$ of the time workers were not related to the vessel owner. Vickers, Farmers and Fishermen, 166. Moreover, Knight was exceptional when it came to employing his family members, as evidenced in the paragraph above. If ever there was a case to be made for kinship ties playing a decisive role in labor recruitment a majority of the time, Knight would have been the best illustration.

In addition, assembling crew lists from merchant ledgers and shipping papers can be problematic. At times, incomplete or illegible ledgers made it impossible to compile lists for certain fares. Such fragmentary crew lists were only used in those cases when this was warranted. Partial crew lists were included along with complete crew lists in the first two databases where I test whether skippers or vessel owners had more of a say in labor recruitment in order to get at as much of this picture as possible. Only full crew lists were used in evaluating kinship ties between crewmembers. In this way, the calculations reveal the highest degree of reliability.

\footnotetext{
${ }^{34}$ Data compiled from William Knight Account Book, 1767-1781, JDPL.

${ }^{35}$ Data compiled from Thomas Pedrick Account Book, 1760-1790, MDHS.

${ }^{36}$ Data compiled from Richard Pedrick Account book, 1767-1784, MDHS.

${ }^{37}$ Data compiled from Joshua Burnham Papers, 1758-1817, JDPL.

${ }^{38}$ Data compiled from Daniel Rogers Account Book, 1770-1790, JDPL.
} 
John Stevens of Gloucester between 1767 and 1775, none shared the owner’s surname. ${ }^{39}$ Also, of the 41 instances in which fishermen went to sea for Richard Derby of Salem between 1756 and 1765, none shared the owner's surname. ${ }^{40}$ Similarly, of the 326 instances in which fishermen went to sea for Timothy Orne of Salem between 1752 and 1767, none shared the owner's surname. ${ }^{41}$ Of the 69 instances in which fishermen went to sea for Miles Ward of Salem between 1765 and 1766, none shared the owner's surname. ${ }^{42}$ Of the 134 instances in which workers went to sea for Thomas Davis of Beverly between 1771 and 1773, none shared the owner's surname. $^{43}$ In aggregate, none of these 1,356 berths was occupied by an identifiable relative of the vessel owner. In total, then, just 64 of the 2,114 berths, or $3 \%$, were occupied by workers with kinship ties to vessel owners. While certain employers, such as William Knight, were more inclined than others to hire relatives, most did not.

The picture is similar when we examine the kinship ties between skippers and crewmembers. First, we will examine those crew lists in which the surname of at least one crewmember matched the skipper's last name. On 11 fares in which Joshua Burnham skippered vessels for Francis and John Choat of Ipswich between 1768 and 1777, there were four fares (four of seventy-seven berths) in which a single worker shared the skipper's surname. ${ }^{44}$

Skippers in Gloucester did not behave differently. Between 1767 and 1774, two Gloucester skippers, Captain John Babson and William Babson, worked on a combined 23 fares for vessel owner John Stevens. On eleven of these fares a single worker shared the skipper's

\footnotetext{
${ }^{39}$ Data compiled from John Stevens Account Book, 1769-75, JDPL.

${ }^{40}$ Data compiled from Richard Derby Ledger, 1757-1776, JDPL.

${ }^{41}$ Data compiled from Timothy Orne Shipping Papers, JDPL; and Timothy Orne Ledgers, 1762-1767, JDPL.

42 Data compiled from Miles Ward Ledgers, 1765-1772, JDPL.

${ }^{43}$ Data compiled from Thomas Davis Account Book, 1771-78, JDPL.

${ }^{44}$ Data compiled from Joshua Burnham Papers, 1758-1817, JDPL.
} 
surname, and there were three fares when two such workers went to sea. ${ }^{45}$ Thus, 17 of the possible 161 berths were filled with relatives of these two skippers. From 1771 to 1775, nine Gloucester skippers, John Collens, Alford Davis, John Morgan, Lemuel Collings, John Parsons, Joshua Parsons, Lemuel Stanwood, Isaac Lane, and Theophilus Lane, worked on a combined 49 fares for vessel owner Daniel Rogers. On 23 of these fares a single worker shared the skipper's surname, and there were seven fares when two such workers went to sea and nine fares when there were three such workers. ${ }^{46}$ In other words, 64 of the possible 343 berths were filled with relatives of these eight skippers. In aggregate, the eleven Gloucester skippers between 1767 and 1775 filled 81 of the 504 berths, or $16.1 \%$, with men who shared their surnames.

The story was much the same in Marblehead. Between 1766 and 1774, five Marblehead skippers, Jeremiah Roles, John Dixey, Thomas Brimblecom, Samuel Smith, and John Lewis, worked on a combined 22 fares for vessel owner Richard Pedrick. On 15 of these fares a single worker shared the skipper's surname. There were also two fares in which two such workers went to sea and one fare when there were three such workers. ${ }^{47}$ Thus, 22 of the possible 154 berths were filled with relatives of these five skippers. From 1761 to 1775 five Marblehead skippers, Ambrose Lovis, Andrew Stacey, Richard Dixey, Nicholas Girdler, and Jonas Dinnis, Jr., worked on a combined 25 fares for vessel owner Thomas Pedrick. On 18 of these fares a single worker shared the skipper's surname, and there were two fares when two such workers went to sea. ${ }^{48}$ In other words, 22 of the possible 175 berths were filled with relatives of these five skippers. Moreover, from 1767 to 1775, three Marblehead skippers, Robert Knight, Jr.,

\footnotetext{
${ }^{45}$ Data compiled from John Stevens Account Book, 1769-75, JDPL. The accounts provide data for previous years, beginning in 1767.

${ }^{46}$ Data compiled from Daniel Rogers Account Book, 1770-1790, JDPL.

${ }^{47}$ Data compiled from Richard Pedrick Account book, 1767-1784, MDHS.

${ }^{48}$ Data compiled from Thomas Pedrick Account Book, 1760-1790, MDHS.
} 
John Chin Knight, and Phillip LeCraw, worked on a combined 35 fares for vessel owner William Knight. On 23 of these fares a single worker shared the skipper's surname. ${ }^{49}$ Thus, 23 of the possible 245 berths were filled with relatives of these three skippers. In aggregate, the thirteen Marblehead skippers between 1761 and 1775 filled 67 of the 574 berths, or $11.7 \%$, with men who shared their surnames.

Beverly skippers behaved similarly. Between 1771 and 1772, two Beverly skippers, Richard Ober and John Lovett, worked on a combined eleven fares for vessel owner Thomas Davis. On eight of these fares a single worker shared the skipper's surname, and there were three fares when three such workers went to sea. ${ }^{50}$ In short, 17 of the possible 77 berths, $22.1 \%$, were filled with men who shared the skippers’ surnames.

Recruitment patterns were not quantitatively different in nearby Salem. Between 1752 and 1764, three Salem skippers, Benjamin Henderson, John Felt, and John Cloutman, worked on a combined 60 fares for vessel owner Timothy Orne. On 30 of these fares a single worker shared the skipper's surname. ${ }^{51}$ Then, in 1766, John Robertson skippered three fares for the Salem vessel owner Miles Ward. ${ }^{52}$ On all three fares a single worker shared the skipper's surname. Thus, 33 of the possible 441 berths in Salem, or 7.5\%, were filled with relatives of the four skippers. In aggregate, on 239 fares, 193 out of 1,673 possible berths (11.5\%) were occupied by men who shared the skippers' surnames.

Now we will look at those instances in which none of the crewmembers shared skippers' surnames. Between 1769 and 1774, two Gloucester skippers, Isaac Ball and David Walles, Jr., worked on a combined 23 fares for vessel owner John Stevens in which none of the workers

\footnotetext{
${ }^{49}$ Data compiled from William Knight Account Book, 1767-1781, JDPL.

${ }^{50}$ Data compiled from Thomas Davis Account Book, 1771-78, JDPL.

${ }^{51}$ Data compiled from Timothy Orne Shipping Papers, JDPL; and Timothy Orne Ledgers, 1762-1767, JDPL.

${ }^{52}$ Data compiled from Miles Ward Ledgers, 1765-1772, JDPL.
} 
shared the skippers' surnames. ${ }^{53}$ From 1770 to 1773, four Gloucester skippers, David Walles, Jr., Joshua Haskell, William Morgan, and Abraham Riggs, worked on a combined 16 fares for vessel owner Daniel Rogers in which none of the workers shared the skippers' surnames. ${ }^{54}$ In other words, on 39 fares out of Gloucester between 1769 and 1774, none of the 273 berths were occupied by men who shared the skippers’ surnames.

The story was similar in Marblehead. In 1772, John Spinney skippered three fares for Richard Pedrick of Marblehead, and there were no fares in which any worker shared the skipper’s surname. ${ }^{55}$ Between 1762 and 1768, three Marblehead skippers, William Vickery, William Trefry, and Robert Smith, Jr., worked on a combined nine fares for vessel owner Thomas Pedrick, and there were no fares in which any worker shared the skippers' surnames. ${ }^{56}$ Thus, on 12 fares out of Marblehead between 1762 and 1772, none of the 84 berths were occupied by men who shared the skippers’ surnames.

In other ports, there were fares in which no crewmember was related to the skipper. David Felt skippered six fares for Timothy Orne of Salem between 1758 and 1759, and there were no fares in which any worker shared the skipper's surname. ${ }^{57}$ Joseph Lovett skippered six fares for Thomas Davis of Beverly between 1771 and 1772, and there were no fares in which any worker shared the skipper's surname. ${ }^{58}$ Taking Gloucester, Marblehead, Salem, and Beverly together, there were 63 fares, or 441 berths, in which none of the crew shared the skipper's surnames.

\footnotetext{
53 Data compiled from John Stevens Account Book, 1769-75, JDPL.

${ }^{54}$ Data compiled from Daniel Rogers Account Book, 1770-1790, JDPL.

55 Data compiled from Richard Pedrick Account book, 1767-1784, MDHS.

${ }^{56}$ Data compiled from William Knight Account Book, 1767-1781, JDPL.

${ }^{57}$ Data compiled from Timothy Orne Shipping Papers, JDPL; and Timothy Orne Ledgers, 1762-1767, JDPL.

${ }^{58}$ Data compiled from Thomas Davis Account Book, 1771-78, JDPL.
} 
Now, we must combine these two differently structured ship-borne labor environments vessels in which labor recruiters were somewhat inclined to let family members on board, and vessels in which recruiters were not so inclined. In aggregate, the skippers were responsible for a total of 302 fares. This figure corresponds to 2,114 occasions, or berths, when it was possible for a skipper's family member to go with him to sea. Overall, such familial recruitment only occurred 193 times, or $9.1 \%$. The fact that more than three-times as many workers were recruited with kinship ties to skippers (9.1\%) as opposed to vessel owners (3\%) underscores the dominant role the former played in the recruiting process. Although it is hard to be precise about the motivations of labor recruiters, it appears that kinship played a smaller role than gender, age, or race in the selection of crews. A majority of the time labor recruiters were very particular about who could work in the industry, and by-and-large they chose young, white, male, nonfamily members to go to sea with them. ${ }^{59}$

Kinship may have played a minor role in labor recruitment in the cod fisheries because skippers and merchants did not want to subject their family members to the rigors and dangers of deep sea fishing. Christopher Prince's father, for example, who was a seaman-turned-farmer, knew that commercial fishing was by no means an easy way to make a living. Indeed, that is precisely why he allowed his son to join a cod fishing company in the first place. According to Prince, who ended up not pursuing a career in commercial fishing, his father acknowledged "he had hopes from the commencement by my going a fishing would wean me from pursuing” a life at sea ${ }^{60}$ Fathers like Prince's wanted a better, easier life for their sons.

\footnotetext{
${ }^{59} 87.9 \%$ of the time labor recruiters chose non-family members to go to sea with them based on the above calculation of surnames. If we were to double the $12.1 \%$ to roughly estimate female kinship ties, then the total would be $75.8 \%$.

${ }^{60}$ Crawford, ed., The Autobiography of A Yankee Mariner, 18.
} 
There was a demographic shift throughout eighteenth-century British North America, particularly in Massachusetts fishing ports, that enabled labor recruiters to find alternatives to family labor. The total population in New England grew from 22,900 in 1650 to 170,900 in 1720, realizing slightly more than a 7.7-fold increase. ${ }^{61}$ Between 1650 and 1725, fishing ports in Essex County, Massachusetts experienced a ten-fold increase in population. ${ }^{62}$ Salem, Beverly, Manchester, and Gloucester grew from a combined population of 3,500 in 1690 to 16,000 in $1765{ }^{63}$ Within this county-wide expansion, Marblehead experienced the fastest growth. Some 1,200 people lived there in 1700, one-third the number in nearby Salem. As early as 1720, the two ports housed 2,000 people apiece. ${ }^{64}$ By 1744, one observer estimated that 5,000 people lived and worked in Marblehead. ${ }^{65}$ By comparison, Boston’s population expanded from 6,000 in 1690 to 17,000 in $1740 .{ }^{66}$ This growth virtually eliminated the endemic labor scarcity that plagued New England during the seventeenth century, enabling employers to discriminate in their hiring practices and dip into local labor pools for help. ${ }^{67}$

As distinct from merchants and skippers, laborers in the commercial cod fishing industry in colonial Massachusetts oftentimes had no alternative but to take their family members with them to sea in the same vessel. Mothers and wives may have wanted their sons and husbands to work on separate vessels in order to lessen the risk of losing multiple loved ones in a storm or work-related accident. However, the same demographic shift that enabled labor recruiters to

${ }^{61}$ McCusker and Menard, The Economy of British America, 1607-1789, 103, Table 5.1.

${ }^{62}$ Vickers, Farmers and Fishermen, 156.

${ }^{63}$ Vickers, Farmers and Fishermen, 211.

${ }^{64}$ Heyrman, Commerce and Culture, 245.

${ }^{65}$ Carl Bridenbaugh, ed., Gentleman's Progress, The Itinerarium of Dr. Alexander Hamilton, 1744 (Chapel Hill: The University of North Carolina Press, 1948), 5.

${ }^{66}$ Gary B. Nash, The Urban Crucible: Social Change, Political Consciousness, and the Origins of the American Revolution (Cambridge: Harvard University Press, 1979), 54-55. For more on this population growth, and the causes behind it, see chapter three.

${ }^{67}$ For more on the localism of eighteenth century labor recruitment in the cod fisheries, see Vickers, Farmers and Fishermen, 166; and Handcock, Soe longe as there comes noe women, 145-216. 
discriminate in their hiring practices also worked against laborers by generating underemployment. As soon as there were more men in Massachusetts than jobs, a chronic and lasting problem emerged in maritime communities as it had in farming communities. ${ }^{68}$

When a skipper required hands, workers grabbed their out-of-work relation and joined the company in need. James Andrews and Daniel Andrews shipped together on the Polly for the summer fare out of Ipswich in 1774. John and James Bowden joined the company of the Marblehead schooner Barnett for a fall fare in $1773 .^{69}$ James and William Jones joined the company of the Gloucester schooner Britannia for all three fares in $1772 .^{70}$ Jeremiah and Jonathan Foster joined the company of the Beverly schooner Swallow for two fares in $1771 .^{71}$ Benjamin Peters and his son, Benjamin Jr., joined the company of the Salem schooner Lucretia for the second and third fares in $1765 .^{72}$ Out of 1,608 individual berths between 1752 and 1775 for which there is sufficient data, slightly more than half $(53.7 \%)$ of the time at least two crewmembers shared the same surname. $12.7 \%$ of the time there were two kinship ties between the crewmembers. However, only $3 \%$ of the time there were three such ties on board. Clearly, horizontal social networks among fishing crews were denser than the vertical networks between crewmembers and those responsible for labor recruitment in the industry. And this was not the only difference between skippers and the rest of their fishing companies.

\footnotetext{
${ }^{68}$ Vickers, Farmers and Fishermen, 187-188; and Robert A. Gross, The Minutemen and Their World (New York: Hill and Wang, 1976), 78-79, 86-89. Gross describes the farming community of Concord, Massachusetts as "an economy of increasing scarcity in an environment of spreading blight" on the eve of the American Revolution. Ibid., 88.

${ }^{69}$ William Knight Account Book, 1767-1781, JDPL.

70 John Stevens Account Book, 1769-75, JDPL.

${ }^{71}$ Thomas Davis Account Book, 1771-78, JDPL.

${ }^{72}$ Miles Ward Ledgers, 1765-1772, JDPL.
} 


\section{$2.3 \quad$ LABOR HIERARCHY}

Enlarged local labor pools combined with new vessel design to widen the labor hierarchy in the cod fisheries, expanding the gulf between the skipper and the rest of his crew. Schooners such as the Polly began replacing smaller shallops around the turn of the eighteenth century. ${ }^{73}$ They were typically 20 to 100 tons in burden, "two-masted oceangoing craft - thirty-five to sixty-five

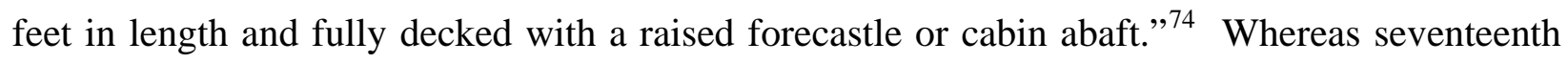
century fishing vessels were typically manned by three, mostly experienced fishermen, eighteenth century vessels averaged seven-man crews. ${ }^{75}$ Larger crew sizes brought increased variation in age and skill, and by the middle of the eighteenth century there was a hierarchy in

\footnotetext{
${ }^{73}$ The origins of the schooner are as yet obscure. John J. Babson, a Gloucester, Massachusetts native, first placed the time and date of the schooner's birth at precisely Gloucester, 1713, owing to the unsubstantiated claim of Captain Andrew Robinson, another native of Gloucester. John J. Babson, History of the Town of Gloucester, Cape Ann, Including the Town of Rockport (Gloucester, Mass.: Peter Smith Publisher, Inc., 1972; orig. pub. 1860), 248255. In succession, McFarland, Robert Greenhalgh Albion and Jennie Barnes Pope, Innis, and Vickers followed Babson's lead. McFarland, A History of the New England Fisheries, 82; Robert Greenhalgh Albion and Jennie Barnes Pope, Sea Lanes In Wartime: The American Experience, 1775-1942 (New York: W.W. Norton and Company, Inc., 1942), 20; Innis, The Codfisheries, 166; and Vickers, Young Men and the Sea, 75. However, William Avery Baker forcefully contends: "The story of the supposed invention of the schooner in Gloucester about 1713 need not be repeated here, for the schooner rig...existed before that date." William Avery Baker, "Vessel Types of Colonial Massachusetts," in Seafaring In Colonial Massachusetts: A Conference Held By the Colonial Society of Massachusetts, November 21 and 22, 1975 (Boston: The Society; distributed by the University Press of Virginia, 1980), 19. For his part, Peter Pope has referred to the ketch, "a small, seaworthy, beamy, flush-decked, double-ended vessel” developed in the mid-seventeenth century, as “a protoschooner." Pope, Fish Into Wine, 153. The most systematic effort to get at the schooner's origins can be found in Basil Greenhill, The Merchant Schooners, $2^{\text {nd }}$ ed., (Annapolis, MD: Naval Institute Press, 1988; first published in 1951), 6-14. Greenhill argues that, "as far as it is possible to tell," the brigantine evolved into the schooner over "the course of the eighteenth century." Ibid., 6. However, he notes that schooners may have been derived from similar Dutch models dating from the turn of the seventeenth century. For similar arguments that the schooner rig was not first designed in America, see William M. Fowler, Jr., Rebels Under Sail: The American Navy During the Revolution (New York: Charles Scribner's Sons, 1976), 265, footnote \#17; and Howard I. Chapelle, The Search for Speed Under Sail, 1700-1855 (New York: Norton, 1967), 11.

${ }^{74}$ Vickers, Farmers and Fishermen, 145. By comparison, shallops averaged six tons burden in 1676. Ibid., $121 \mathrm{n}$.

${ }^{75}$ Boatmasters, or steersmen, and midshipmen tended to be more experienced, skilled laborers, while foreshipmen were usually unskilled boys and green hands. These early workers were supported on shore by skilled laborers such as the splitter, header, and salter. Vickers, Farmers and Fishermen, 123-125; and Pope, Fish Into Wine, 176-177, esp. Table 9n. According to one seventeenth century observer at Newfoundland, "the boats' masters, generally, are able men, the midshipman next, and the foreshipmen are generally striplings." Quote taken from Head, Eighteenth Century Newfoundland, 3. The average crew size was 7.4 men. This figure was calculated from sources listed above in footnotes 34-43.
} 
the commercial fisheries with skippers at the top, sharesmen in the middle, and cuttails at the bottom.

There were important differences that separated skippers from the rest of the crew. First and foremost, commanders of fishing vessels were skilled in the art of navigation. They were responsible for taking daily observations, recording the speed and direction of winds and ocean currents, writing down depth levels, noting the condition of the sea and weather, and calculating longitude and latitude. Moreover, skippers were charged with plotting a course to and from the home port and the fishing waters. ${ }^{76}$ Such knowledge distanced a skipper from his crew in the same way that it separated a merchant captain from his tars.

Skippers had a variety of responsibilities that further set them apart. They were expected to use their navigational skills and experience to make arguably the most important decision of an expedition: where to fish. They were accountable for assembling the crew, counting each cuttails' catch of fish, in addition to the total fish count for the vessel, and setting watches at night.

These duties are reflected in the log books for fishing vessels. Unfortunately, a log for one of the schooner Polly's fishing expeditions has not survived. John Lovett, commander of the schooner Volant, went on a typical fishing expedition from Beverly, Massachusetts to the fishing bank off Sable Island in late April, 1769, on what was a spring, or first, fare. In the first log entry for Friday, April 24, the weather turned “cloudy... and foggy, with Souther[ly] Winds.” It soon began to rain and Lovett ordered "our fore Sail” reefed in preparation for a hard blow. “The Wind veered to the Westward and Cleared of[f]," however, and Lovett "Saw the Sun."

\footnotetext{
${ }^{76}$ For evidence of fishing skippers' knowledge and practice of navigation, see George Stevens Logbooks, 17681774, MHS; log of the schooner John, 1762; schooner Ruby, 1788; schooner St. Peter, 1793; Microfilm \#91, Reel 68, JDPL; and the log of the schooner Nancy 1795-96, Microfilm \#91, Reel 3, JDPL.
} 
Early the following day, with wind beating from the "NW" and "Cloudy Weather most part of the time," Lovett headed the schooner "EBS" in order to make "our Course due East." The skipper noted that "the Wind [beat] at NBE" until "6 of the Clock in the morning." At that point, "the wind veered to the Westward and She made her course EBN; and at 8 of the Clock in the morning [headed] ENE till 10 of the Clock; and then Came up to NE1/2E and Run so till 12 of the Clock.” After a sailing time of three days, Lovett recorded his position as latitude $43^{\circ} \mathrm{N}$ $27^{\prime}$ and longitude $62^{\circ} \mathrm{W}$ 08', on the southwest corner of Sable Island Bank. With "Northerly winds and Cloudy Weather...We Laid too till 4 of the Clock and Caught about 130 fish and then bore away and we run under our [w]hol[e] Sails till 8 of the Clock in the morning and the wind veered out to the Eastward.”

On Monday, April 27, the crew of the Volant experienced "Westerly winds and rainy weather." Lovett ordered the crew to lower "our fore Sail," and the schooner ran thus until "6 of the Clock in the morning." At this point, the skipper ordered "Soundings on the Western ground,” or the outer edge of Sable Bank. He found they were "in about 50 fathoms of Water.” Lovett noted that the men "tried all day and caught but one fish and Spoke with a Cape Anne man." That night, the skipper "Laid her too under her fore Sail and Set the Watch and Went to Cabin.” Before his head hit the pillow, Lovett recorded their position as latitude $43^{\circ} \mathrm{N} 32$ ' and longitude $59^{\circ} \mathrm{W} 42^{\prime}$. The following day, he observed: “This 24 past Cloudy Weather and Westerly Winds and fish Very Scarce; and Spoke With a Cape Ann Man and at Night Laid her too under two Re[e]fs Fore Sail.” The crew stayed on the Sable Bank for the next four weeks. On June 1 "We hove up on the Western ground and bore W to go home; all Well aboard; at 12 of the Clock the Western End of Newfoundland bore NNE, Distance 15 miles.” With winds blowing "EBN" and the current running "WBN" the Volant headed toward Beverly and reached 
the port after a quick, uneventful sailing time of six days. ${ }^{77}$ The very fact that skippers were literate and kept such log books separated them from the rest of the crew.

Skippers and sharesmen were further separated from the cuttails by age, experience, and earnings. The skipper typically earned the same amount as the sharesmen on these fishing expeditions. Both types of workers were in most cases above the age of twenty-one. These men had prior experience on board a fishing vessel, were considered skilled laborers, and were guaranteed five-eights of the profits from the sale of the catch to the outfitting merchant. ${ }^{78}$

Younger, inexperienced, and therefore less productive, cuttails earnings were different. They were only guaranteed the promise of a flat rate for every fish they caught, plus a small annual wage that was referred to as "gratis money," earnings that were separate, or free, from the count of their fish. In addition, cuttails' earnings were deposited in accounts controlled by older family members, usually a father or mother, but sometimes an older sibling. ${ }^{79}$ The cuttails were divided again by their age and ability, and their earnings usually reflected these characteristics. "Stumps" typically were at the bottom of the cuttails, and earned the least. "Swallows" were next in line, then “doubles.” At the top of the unskilled hierarchy, with earnings that typically outpaced the others, was the "single." Occasionally, one of the lower cuttails could outwork his unskilled shipmates and earn more as a result. On William Knight’s Marblehead schooner Molly

${ }^{77}$ Log of the schooner Volant, George Stevens Logbooks, 1768-1774, MHS.

${ }^{78}$ Vickers, Farmers and Fishermen, 161, 173-174.

${ }^{79}$ Ibid. Vickers does not discuss gratis money, but evidence that it was provided to younger workers can be found in William Knight Account Book, 1767-1781, JDPL; and Thomas Pedrick Account Book, 1760-1790, MDHS. For example, William Knight's Marblehead schooner Molly left after September 22, 1767, on a fall fare. The vessel was manned by a seven-man crew, including four sharesmen and three cuttails. Of the later, Samuel Andrews, the "single," caught fish worth £12.2.8, plus £0.8.0 in gratis money (in inflated colonial Massachusetts' currency). Thomas Salter, the "double" caught fish worth $£ 10.17 .3$, plus $£ 0.8 .0$ in gratis money. Christopher Oaks, the "swallow," caught fish worth £6.7.10, plus $£ 0.5 .0$ in gratis money. Such a small annual wage had been provided to younger, less-skilled workers in the Newfoundland fisheries since at least the seventeenth century. Pope, Fish Into Wine, 175, 186-187. Pope suggests that the introduction of the wage in this manner eventually led to "the broader trend to a greater emphasis on wages in the remuneration of skilled workers." Ibid., 187. Thus, the use of gratis money among eighteenth century New England merchants can be seen as an attempt to convert the industry to a wage system. 
in 1768, the stump, Samuel White, earned more for the fall fare than the swallow, William Courtis; and the double, John Chin Knight, earned more than the single, Thomas Salter, Jr. On the same schooner in 1775 , the stump, Robert Courtis, earned more for the spring fare than the swallow, Elias Hammon. ${ }^{80}$ These were exceptional cases, however.

Occupational mobility within this eighteenth-century labor hierarchy is difficult to determine. No record exists describing the precise way in which workers were promoted. In merchant ledgers, the best surviving source, it is possible only to determine the rank of a crewmember in those rare instances when the trader took the time to list the rank after the man's name, or when the crew went on the share system. There is evidence to suggest that vesselowning merchants were involved in deciding who was promoted from sharesman to skipper. John Chin Knight, for example, worked for his relation William Knight of Marblehead on the schooner Molly as a double in 1768. He then worked as a single on Knight's schooner Barnett for five fares between 1769-70. In the fall fare of 1770, John was promoted to sharesman. He worked as sharesman for the next three years until he made skipper of the Barnett in the fall fare of 1773 . He remained skipper until the outbreak of the Revolutionary War. ${ }^{81}$ Thus, promotion probably depended on the vessel owner's will as much as the sharesman's whim. Almost universally, new skippers had worked as sharesmen for vessels with the same owner. Phillip Babson worked as a sharesman on John Stevens' Gloucester schooner Victory before being made skipper in 1770. John Barker did likewise on Richard Pedrick's Marblehead schooner Molly before being made skipper in 1769. John Carwick worked as a sharesman on Timothy Orne’s Salem schooner Esther before being made skipper in 1766. In general, such upward mobility did not occur frequently and was not widespread in the commercial cod fishing industry. There were

\footnotetext{
${ }^{80}$ William Knight Account Book, 1767-1781, JDPL.

${ }^{81}$ William Knight Account Book, 1767-1781, JDPL.
} 
too many workers and too few skipper positions. Moreover, the navigational skills and knowledge necessary for the skipper position had to be learned and paid for. Adults could take classes with teachers such as Benjamin Bangs, and children could do formal apprenticeships with sea captains to learn the "Art, Trade \& Mystery of Navigation." ${ }^{82}$ Like the "lower sort” among Philadelphia’s eighteenth century laboring community, occupational mobility was possible to achieve but it was not common. ${ }^{83}$

The advancement of a cuttail was most likely decided on over hard cider or rum in a local tavern following an expedition. The loyalty of fishing companies to particular outfitters had declined in the eighteenth century partly as a result of merchants' unwillingness to extend credit on liberal terms to any employee, regardless of their tenure. ${ }^{84}$ This situation further weakened the vessel owner's control over promotion within the ranks of a particular company. Given the general lack of vessel owners' involvement in labor recruitment at the lower levels, it is certain that skippers enjoyed a great deal of authority in deciding which cuttails were promoted to the rank of sharesmen, and when. It is also possible that the skipper relied on the collective agreement of the experienced hands when it came time to make such a decision. Every additional sharesmen decreased the size of individual shares, which meant these experienced hands would have had a vested interest in deciding who was added to their ranks.

\footnotetext{
${ }^{82}$ For evidence that older men took classes from teachers, see Benjamin Bangs Diary, 1742-1765, MHS. For an actual apprenticeship, see Aaron Parsons, Sr., Shipping Papers, Box 8, Folder 7, JDPL, esp. "Shipping records for Captain Paul Dolliver, 1750-1770.” On October 10, 1759, Thomas Groves “a Minor aged fifteen years” and resident of Gloucester "bound himself" to Paul Dolliver "Gloucester Mariner, to learn his Art, Trade \& Mystery of Navigation." Groves agreed to serve Dolliver, his wife Rachel, and his heirs, for the term of "six years."

${ }^{83}$ Billy G. Smith, The "Lower Sort”: Philadelphia’s Laboring People, 1750-1800 (Ithaca, N.Y.: Cornell University Press, 1990), 126-149. According to Smith, "Occupational mobility among mariners was no better than it was among either laborers or journeymen cordwainers and tailors. The promotion of a common sailor to ship's officer was extremely rare." Ibid., 142. Vickers maintains a more positive view of promotion rates with respect to Salem's colonial merchant marine. He calculates that between 1745 and 1759, 49\% of all Salem-born seamen became mates and 27\% became shipmasters. Vickers, Young Men and the Sea, 112.

${ }^{84}$ Vickers, Farmers and Fishermen, 162.
} 
This decision was a complex one. A skipper could recruit a larger crew for the next expedition by hiring a new cuttail to fill the void in the lower ranks. Alternatively, the skipper could decide to use more sharesmen in the company. However, given the fact that the ratio of sharesmen to cuttails remained fairly constant, thus ensuring a steady flow of coin and credit into sharesmen's pockets, it is probable that one advanced into the sharesmen ranks only when an experienced hand left, died or was fired. ${ }^{85}$ In short, we can surmise from the surviving evidence that cuttails were hired young and seasoned over a period of years during which older sharesmen passed their prime and retired, willingly or no, got angry and left, or died. After some experience, younger cuttails were promoted to fill any openings among the sharesmen. Such an "informal apprenticeship mechanism” was also part-and-parcel to the Newfoundland fisheries. ${ }^{86}$ If, however, an ambitious cuttail came of age and there was no such opening on a particular vessel, then the young man might grow frustrated, leave the company and search for an opportunity on another schooner.

Once he had attained the rank of skipper and recruited a company, Burnham contracted with an outfitting merchant for employment. In the summer of 1774, he made an agreement with Francis and John Choat in Ipswich. This agreement may have been verbal or written. In 1768, Marblehead’s selectmen maintained "that Fishermen ship themselves on board Fishing Vessels for such time \& on such Terms as is verbally agreed on." ${ }^{87}$ Yet, Gloucester merchant Ezekiel

\footnotetext{
${ }^{85}$ On the Marblehead schooner Molly between 1767-69, there was an 8-man crew on six fares. On all of the fares, the ratio of sharesmen to cuttails remained constant at 4:4. Richard Pedrick Account book, 1767-1784, MDHS.

${ }^{86}$ Pope, Fish Into Wine, 173.

87 "Petition of the Selectmen of Marblehead [To Governor Francis Bernard and the Massachusetts General Court] asking for the passage of an act relating to the Cod-fishery, with a copy of said act,” 1768, MSA Collections, Vol. 66, Maritime, 1759-1775, 406-409. In place of this verbal agreement, which the selectmen believed led to "many Evils," they proposed the following: "before they leave the Port or place to pursue such Voyage, the Owner, Skipper, \& Crew shall sign a duplicate of an agreement in form following, viz. 'These Present witness That [blank] being appointed Skipper of the Schooner called the [blank], [blank] owner, \& [initials of the crew] crew on board
} 
Woodward, Jr. agreed on paper on September 18, 1762 to “Engage to Give Joshua Burnham Six Pounds Thirteen Shillings and 4 [pence] for Each Thousand of Cod fish said Burnham Shall Catch on Board my Schooner [Abigail] this fall fare on the Banks \& Bring home.”88 Also, in 1758 the crew of the schooner Molly signed a written document with Salem merchant Timothy Orne agreeing to go "upon a Fishing Voyage in Said Schooner for the Next Season upon Common Share or upon Sell Fish.» ${ }^{89}$

While the agreement between Burnham and the Choats has not survived, perhaps because there was no written contract, most eighteenth century arrangements, verbal or otherwise, would have had the outfitting merchant agree to provide their vessel along with "great" and "small” general goods for an expedition. Typically, the great general goods consisted of work-related necessaries for the trip: barrels of mackerel or clams for bait, barrels of water, hogsheads of salt, candles, hooks, lines, leads, extra sail cloth, powder, shot, gloves and mittens. The small general goods were for the most part personal necessaries that made the trip less arduous: soap, brooms, brushes, cords of wood, paper, cider, rum, molasses, pepper, beans,

said Schooner for a Fishing voyage intended to be made in her from this day until the [blank] day of [blank] next, Do severally engage to perform their respective duties on board said Vessel during that Time, $\&$ the fish to be caught in her from time to time, to be brought home to [blank] \& delivered to the said [blank] on order as Shoreman to cure \& fill for market, which the said [blank] hereby engages to do \& render to the said Skipper \& Crew their respective shares or interest therein. In witness whereof the said parties have herewith set their names this [blank] day of [blank] Anno Dom. [blank];' and when any such crew shall be minors the said agreement shall be signed by their Parents or Guardians who shall have the care of such minors.” The codification of labor agreements between merchant and laborer here are very similar to Parliament's 1729 "Act for the Better Regulation and Government of the Merchants Service.” For a discussion of the 1729 Act, see Marcus Rediker, Between the Devil and the Deep Blue Sea (Cambridge: Cambridge University Press, 1987), 121. Throughout the seventeenth century in Newfoundland, labor contracts “were still normally oral, so that very few fishers' contracts have survived.” Pope, Fish Into Wine, 168.

${ }^{88}$ Joshua Burnham Papers, 1758-1817, Schooner Abigail, [c.1762], Box 1, Folder 1, JDPL. The use of the collective plural "Banks" here, as opposed to a specific regional modifier, underscores the skipper's role in choosing the location for fishing.

${ }^{89}$ Timothy Orne Shipping Papers, schooner Molly, 1758-60, Box 7, Folder 11, JDPL. The share system and the count system, or "Sell Fish," will be explained later in this chapter. 
flour, beef, oil and lamps. ${ }^{90}$ In return, fishing companies consented to sell their catch exclusively to the outfitting merchant; return any unused great general goods; and pay for all small general goods that were used on the expedition. Such an arrangement represented a considerable upfront commitment and risk of capital on the part of the outfitting merchant.

\subsection{CAPITAL INVESTMENT}

In 1763, Robert "King” Hooper and Jeremiah Lee carefully calculated the costs involved in sending a fishing vessel and crew out to sea. These men were eminently qualified to make such a calculation. They were two of the foremost merchants involved in the fishing industry in Marblehead, Massachusetts, which at that time was the largest fishing port in colonial New England with regard to number of workers, fleet size, and capital outlay. ${ }^{91}$

The costs associated with commercial fishing were considerable. Hooper and Lee reckoned "the first Cost of a Banker," a vessel capable of working off-shore fishing banks, was $£ 500$. In addition, the total capital outlay for outfitting a crew of 8 for one year was £635. This figure included $£ 160$ for "Vessels ware \& tare;" £195 for provisions used at sea; £40 for “Fishermen’s Clothing;” and $£ 48$ for “Fishermen’s provisions on shore at $£ 6$ per head.” Also, in

${ }^{90}$ The most detailed accounts for these items include: Thomas Davis Account Book, 1771-78, JDPL; William Knight Account Book, 1767-1781, JDPL; and Miles Ward Ledgers, 1765-1772, JDPL.

${ }_{91}$ As a demonstration of his wealth and power, Lee built an enormous mansion house in Marblehead in 1768. At a cost of $£ 10,000$, it was considered one of the most expensive homes in all of the colonies. Hornsby, British Atlantic, American Frontier, 86-87; and Thomas Amory Lee, “The Lee Family of Marblehead,” Essex Institute Historical Collections, Vol. LII, (1916), 331. Also, see figure 4 in chapter five. Lee owned, at one time or another, 45 ships, brigs, snows, sloops, and schooners. At his death, he left an estate valued at £24,583.18.10. Smith, ed., The Journals of Ashley Bowen (1728-1813), Vol.2, 665. For his part, Hooper owned a mansion house, ropewalk, warehouse and wharf, in addition to many vessels. Upon his death in 1790, Hooper’s estate, valued at £5,486.6.4 was declared insolvent due to debt owed to London financiers Champion \& Dickason amounting to £39,650.6.2. Ibid., 661. For more on Marblehead's size and importance, see chapter three. 
recognition of the extent to which fishermen were involved in a debt peonage relationship with merchants, Hooper and Lee factored into the costs of sending a fishing crew to sea the sum of $£ 192$ for selling provisions and clothing to the fishermen’s family while they were employed. This last figure was based on the assumption that at least half of the 8-man off-shore fishing crew, most likely the older sharesmen, had " 4 in his Family besides himself." In short, wealthy fish merchants viewed fishermen's families as sunk costs that needed to be factored into the total capital outlay necessary for retrieving cod from off-shore banks. These families bought goods on credit against their male relation's future earnings. Thus, a merchant had to be prepared and able to supply these items for one year without receiving payment. In total, Hooper and Lee calculated the cost for purchasing a single banker and outfitting a crew and their family for one year to be $£ 1,135$. In the year that Hooper and Lee made these calculations, Marblehead maintained "72 Bankers.”"92 At the same time, Benjamin Pickman and Samuel Gardner, fish merchants from Salem, counted 301 "Vessels Employed in the Fishery in the Province [i.e. Massachusetts], Cod Fishing on the Banks." ${ }^{93}$ Assuming that purchasing and manning these vessels cost their owners $£ 1,135$ per "banker," the Massachusetts deep sea fishing fleet in 1763 represented a total capital investment of £341,635.

\footnotetext{
92 “Calculations respecting outfits of a Fishing vessel,” December 1763, Ezekiel Price Papers, 1754-1785, MHS. In 1755, £1,135 sterling was equivalent to \$131,528.34 in year 2000 U.S. dollars. John J. McCusker, How Much Is That In Real Money? A Historical Commodity Price Index for Use as a Deflator of Money Values in the Economy of the United States, $2^{\text {nd }}$ ed., (Worcester, Massachusetts: American Antiquarian Society, 2001), 35-36. Vickers writes that fishermen's clothing typically included "heavy boots, woolen outerclothing, and thick canvas or leather aprons called barvels." Vickers, Farmers and Fishermen, 122. Pope adds that their clothing was usually made from "kersey," a "coarse, narrow, woven wool cloth, usually ribbed." In addition, fishermen typically wore "a hauling hand," which was "a glove covering the palm, with the fingers protruding, used in handling fishing lines." Pope, Fish Into Wine, 363, Table 25.

${ }_{93}$ Benjamin Pickman and Samuel Gardner of Salem, to John Rowe, Esq., and others Committee of the Society for Encouraging Trade \& Commerce located in Boston, letter dated Salem, December 24, 1763, Ezekiel Price Papers, 1754-1785, MHS.
} 
Despite these expenses, fish merchants still turned profits. In 1776, Massachusetts merchants calculated the "Loss On Income" that resulted from the first year of the Revolutionary War. Business leaders factored into their calculations the profits they lost on each fishing vessel. In Cape Ann, for example, which included three deep-sea ports: Gloucester, Manchester, and Beverly, and four smaller ports: Chebacco, Annisquam, Sandy Bay, and Pigeon Cove, merchants figured that each of their "80 Sail fishing Vessels" brought in an annual net profit of "£100 Each.” Thus, the fishing fleet earned Cape Ann “£8,000” each year. ${ }^{94}$ At the same time, fish merchants in nearby Salem calculated an equivalent profit of "£100 Each" on their fishing schooners. With "50 Sail," these merchants figured the fleet brought into Salem "£5,000" each year. ${ }^{95}$ Assuming the same profits for the Marblehead fish merchants, and taking into account their "72 Bankers," commercial fishing brought $£ 7,200$ net profit into port on an annual basis. In other words, the fishing fleet cost Marblehead fish merchants £81,720 annually, and they earned $£ 88,920$ at the same time. Thus, entrepreneurs in New England’s largest fishing port earned a net profit margin of $8 \%$ from fishing alone

\subsection{DEEP SEA COD FISHING}

Once the Choats had fully provisioned the Polly, Burnham and his crew set sail in June for the Grand Bank off Newfoundland. The timing of their trip in the summer underscores the seasonal nature of life and work in the cod fisheries. Eighteenth-century fishermen typically did not work

\footnotetext{
94 "Estimate of the Loss on Income \& the Trade of Cape Ann from April 1775 to April 1776," NDAR, Vol. 4, 1323-24. The Cape Ann merchants further factored into their financial loss "11,600 of superfine feet Wharf Useless" and "48 Warehouses Useless."

95 "Estimate of the Loss on Income and Trade for the Town of Salem," April 30, 1776, NDAR, Vol. 4, 13241325.
} 
the Bank during the fall, winter, or spring months, because of dangerous temperatures, winds, and seas, combined with the prevalence of fog and icebergs in the region. ${ }^{96}$ At bottom, labor in the fishing industry involved man's struggle and symbiotic relationship with nature. On the one hand, fishermen fought to balance themselves on board wooden vessels caught in rolling seas. They tacked one way and another in order to make headway in the face of contrary winds. The same workers also attempted to stave off cold, damp weather with thick clothing. And a sudden storm could render meaningless anyone's attempts to save the vessel from wrecking. Yet, at the same time fishermen moved with the rhythms of nature. As seasons changed, work patterns were altered. As water temperatures altered, and cod stocks shifted, fishermen moved to different zones. In these ways, Burnham and his crew would have fought with and learned from nature on their sea voyage.

Cod fishermen in eighteenth-century Massachusetts could have worked nearby waters on a year-round basis. The fish do not leave the northwest Atlantic and migrate further to the south in the winter like certain fowl. However, there is no evidence of an extensive winter fishery being prosecuted prior to the American Revolution. The evidence that does exist suggests that winter fares could be difficult and dangerous, and they were rarely successful. Benjamin Bangs worked on cod fishing expeditions out of Eastham, Massachusetts, and he did attempt to work inshore waters off Cape Cod in February 1743. On this expedition, he encountered "a hard NE snow storm," and a "Cold NW wind.” Bangs observed that it was a "tuff time," and that he and the other fishermen could "Catch but 3 Codfish.” On the return trip, he encountered a "NE storm

\footnotetext{
${ }^{96}$ According to Pope, the bulk of fishing activities were conducted off Newfoundland between May and July. Pope, Fish Into Wine, 21-29. Also, see Vickers, Farmers and Fishermen, 104, 116. One observer recorded "Lands of Ice" floating around Newfoundland between March-April, 1726, and further noted that this made it "very dangerous for those that are unacquainted." Quoted in Head, Eighteenth Century Newfoundland, 73. Head notes that a majority of the region's gale-force winds come between December-March. At the same time, the region experiences its highest number of days with precipitation and its lowest temperatures. By contrast, June, July, and August typically maintain low precipitation, slight winds, and warm temperatures. Ibid., 43.
} 
of Rain and snow" and referred to the entire expedition as "a broken voyage."97 In 1760, Robert Hooper, Jr., a fish merchant from Marblehead, petitioned the Massachusetts General Court in order to be reimbursed for a rescue mission. A "Number of People" were working the waters around Sable Island when they were "cast on Shore on said Island and in Danger of perishing by the Severity of the Winter, unless relieved." ${ }^{98}$

The majority of eighteenth-century Massachusetts fishermen, including the crew of the Polly, went to sea in the spring, summer, and fall. Fishing schooners were generally taken out of home ports in March and April to catch spring fare on the first expedition of the year. ${ }^{99}$ In 1753 , Timothy Orne gave orders for John Felt, a skipper who was working as captain of a merchant vessel, to "Be sure to get Ready to Come away by the Last of January if Possible that so you may be at home timely for The Spring Sable [Banks] Fare, which is of more Consequence than the Maryland Voyage.”100 Leaving the Southern colony for home between January and February would have allowed Felt and his crew enough time to catch the first fare off Sable Island.

\footnotetext{
${ }^{97}$ Benjamin Bangs Diary, 1742-1765, MHS. Bangs had better luck working these inshore waters between March 23 and April 23 in 1743.

98 JHRM, Vol. 38, Part II, 278.

99 Trefts asserts "the cod season began in mid-winter (February) and continued virtually year-round.” Trefts, "Canadian and American Policy Making in Response to the First Multi-species Fisheries Crisis in the Greater Gulf of Maine Region,” 209. I have seen no evidence of fishermen leaving in February to go to the banks.

${ }^{100}$ Schooner Molly, Box 7, folder 10, 1751-57, Timothy Orne Shipping Papers, JDPL.
} 


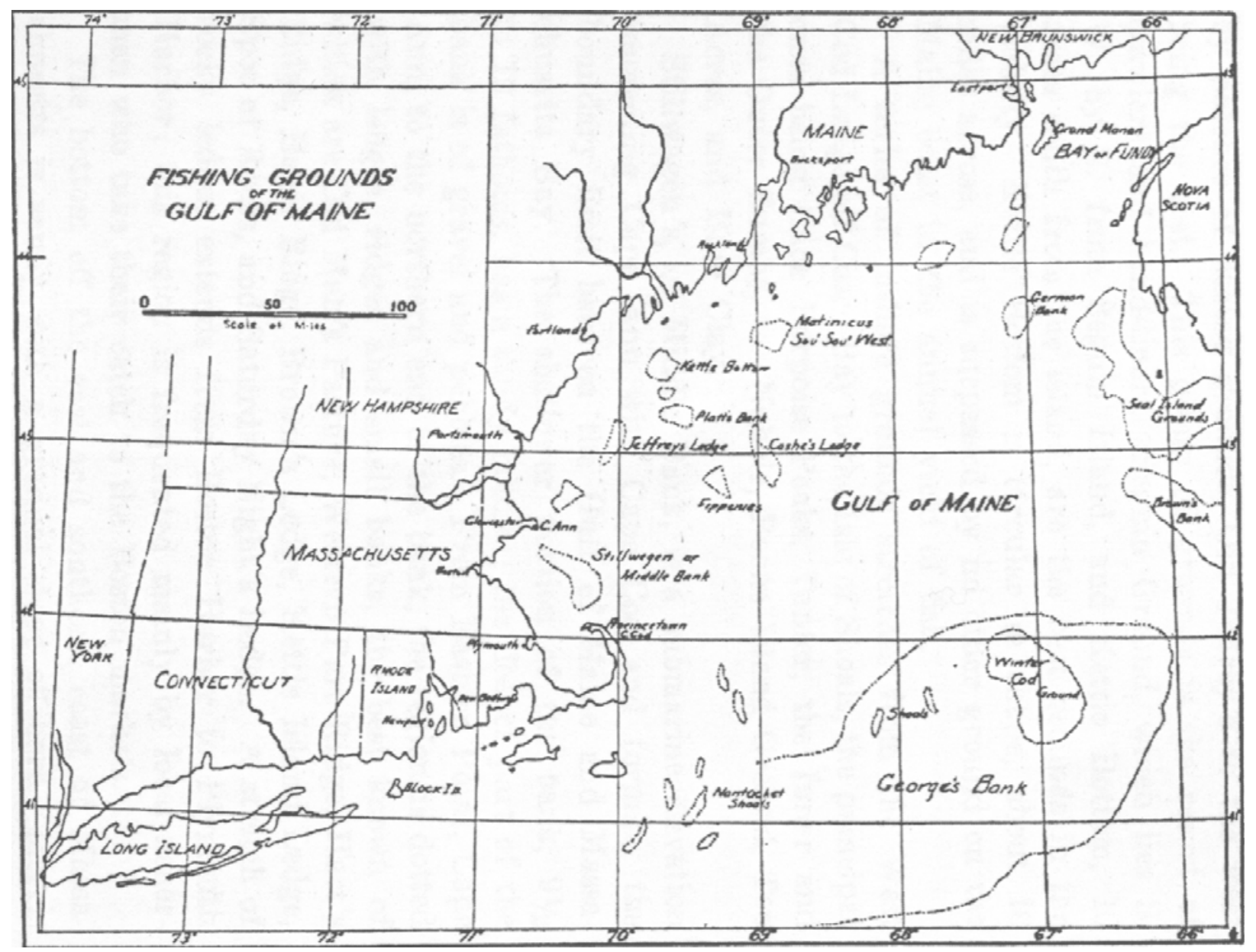

Figure 2: Northwest Atlantic Fishing Grounds A. ${ }^{101}$

During the eighteenth century, fishermen often frequented the waters between Canso Bay in Maine and Sable Island, located southeast of Nova Scotia, 300 miles east of Maine's coast, or around four days sailing time (Compare Figure 2 and Figure 3). ${ }^{102}$ Raymond McFarland describes the Sable Island Bank as "elliptical in form with a length of 156 miles and a width of

${ }^{101}$ McFarland, A History of the New England Fisheries, 11.

102 Trefts, "Canadian and American Policy Making in Response to the First Multi-species Fisheries Crisis in the Greater Gulf of Maine Region,” 206-211; Vickers, Farmers and Fishermen, 148-149. Indeed, one of the fishing grounds off the coast of Maine was named "Marblehead Bank." McFarland, A History of the New England Fisheries, 12. According to Rawlyk, the number of Massachusetts' schooners operating at Canso Bay declined from its height of 223 in 1729 to “only a handful” in 1744. Rawlyk, Nova Scotia's Massachusetts, 130-131. 
56." ${ }^{103}$ Workers traveled here whether it was the spring fare, the summer fare, or the fall fare that ended in October or November. If they did not have good luck, then, like the Polly in 1774, Massachusetts men headed to the "eastward" toward the largest known feeding and spawning ground of Atlantic cod, the Grand Bank (See Figure 3). ${ }^{104}$ McFarland notes that the Bank "is roughly triangular in shape, one side facing N.N.E., another S.W., and the third about E. by S. North and south it extends from below the parallel of $43^{\circ}$ to beyond that of $47^{\circ}$; its width is between the meridians of $48^{\circ}$ and $54^{\circ}$, giving it an area of 37,000 square miles, or more than that of the state of Indiana." 105 At this point in time, no other part of the Atlantic Ocean teemed with cod like the Grand Bank.

${ }^{103}$ McFarland, A History of the New England Fisheries, 14.

${ }^{104}$ For other examples of eighteenth century Massachusetts' schooners traveling to the Grand Bank in the summer months, see George Stevens Logbooks, 1768-1774, MHS; schooner Ruby, 1788; schooner St. Peter, 1793; Microfilm \#91, Reel 68, JDPL; and the log of the schooner Nancy 1795-96, Microfilm \#91, Reel 3, JDPL. Alexander Coffin, a Massachusetts fish merchant, wrote in 1782: "From Cape Sable to the Isle of Sable and so on to the Banks of Newfoundland, are a Chain of Banks, extending all along the Coast, and almost adjoining each other, and are those Banks where our Fishermen go for the first Fare, in the early Part of the Season. Their second Fare is on the Banks of Newfoundland, where they continue to Fish till prevented by the tempestuous and boisterous Winds, which prevail in the Fall of the Year on that Coast. Their third and last Fare is generally made near the Coast of Cape Sables or Banks adjoining thereto, where they are not only relieved from those boisterous Gales, but have an Asylum to fly to in Case of Emergency, as that Coast is lined, from the head of Cape Sable to Halifax, with most excellent Harbors.” L.H. Butterfield, ed., The Adams Papers: Diary \& Autobiography of John Adams, Volume III, Diary 1782-1804 and Autobiography through 1776 (New York: Atheneum, 1964), 74. According to Pope, “Gadus morhua [cod] occupies an ecological niche near the top of the marine food chain, preying on crustaceans and capelin or other small fish, which graze in turn on plankton. Plankton boom around upwellings of cold, nutrient-rich waters. Hence, summer concentrations of cod occur where the southward-trending Labrador Current encounters Newfoundland's promontories, shoals, and islands and exactly where the fishing stations and settlements of the seventeenth and eighteenth centuries were located.” Pope, Fish Into Wine, 24.

${ }^{105}$ McFarland, A History of the New England Fisheries, 14-15. 


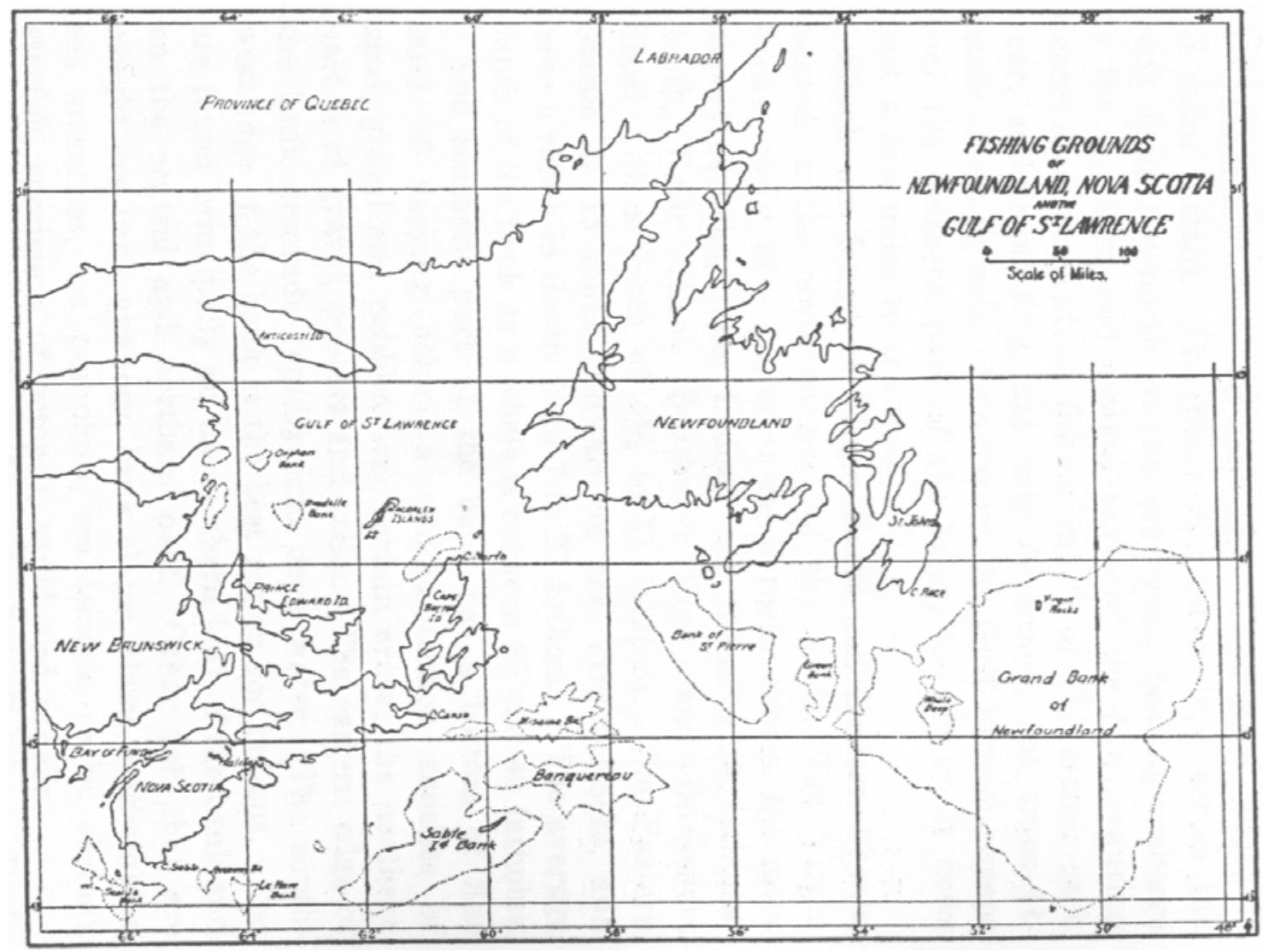

Figure 3: Northwest Atlantic Fishing Grounds B. ${ }^{106}$

After a passage of ten days sailing time, during which the younger cuttails probably cut mackerel and clams into bait while the experienced sharesmen swapped stories, Burnham and the crew of the Polly reached this magisterial stretch of the ocean and dropped anchor. ${ }^{107}$ They would have taken soundings before breaking the water with hand-lines, lead weights, bait, and

${ }^{106}$ McFarland, A History of the New England Fisheries, 14.

${ }^{107}$ Burnham did not record his particular sailing time on this fare. The average sailing time from Beverly, Massachusetts to the Grand Bank in the late eighteenth century was taken from the log of the schooner St. Peter, 1793, Ship's Log Books, Microfilm \#91, Reel 68, JDPL; the log of the schooner Nancy, 1795-1796, Ship’s Log Books, Microfilm \#91, Reel 3, JDPL; and the log of the schooner Lark, 1771, George Stevens Logbooks, 17681774, MHS. By comparison, it took migratory fishing fleets an average of five weeks to travel from their ports in England's West Country to Newfoundland in the eighteenth century. Ian K. Steele, The English Atlantic 16751740: An Exploration of Communication and Community (Oxford: Oxford University Press, 1986), 82. 
hooks. John Thistle, skipper of the Beverly schooner St. Peter, had the crew take a sounding on September 16, 1793. They reported they were in 75 fathoms "on the grand Bank." Later that day, the St. Peter's crew reported a dept of "60 fathoms of warter."108 Skipper John Groves of the Danvers schooner Nancy and his crew came to anchor on the Grand Bank at latitude $45^{\circ} \mathrm{N}$ 7' and longitude $52^{\circ} \mathrm{W} 7{ }^{\prime}$ in July, 1795 . They sounded a depth of 36 fathoms. ${ }^{109}$ George Stevens simply noted that on "Thursday the 28 day of April 1774," his crew "got Soundings on the Grand Bank.”110 By recording ocean depths, fare after fare, year after year, skippers were able to accumulate knowledge about where fish could be caught. Such maritime knowledge could separate the successful fares from the broken voyages.

Burnham and company worked the Grand Bank from Sunday June 26, 1774 to Friday July 15, 1774. Joshua Burnham took 927 cod; Samuel Burnham, 2,000; Peter Edwards 1,913; George Pierce, 1,797; Stephen Low, 1,668; James Andrews, 1,573; Daniel Andrews, 1,384. In all, the 7-man crew took in a catch of 11,262 cod. ${ }^{111}$ Between 1675 and 1775 there was a $75 \%$ increase in the average catch-rate-per-man in the New England cod fishing industry, from 45 to 79 quintals, as a result of the transition to schooners and larger crews. ${ }^{112}$

Deep sea fishing had a reputation as being very physically demanding. A Boston writer referred to it as "one of the most laborious employments." ${ }^{113}$ Christopher Prince described the work as "the most trying of any employment." "114 Fishermen worked a grueling, near continuous

${ }^{108}$ Log of the schooner St. Peter, 1793, Ship’s Log Books, Microfilm \#91, Reel 68, JDPL.

${ }^{109}$ Log of the schooner Nancy, 1795-1796, Ship’s Log Books, Microfilm \#91, Reel 3, JDPL.

${ }^{110}$ Log of an unnamed schooner, 1774, George Stevens Logbooks, 1768-1774, MHS.

${ }^{111}$ Schooner Polly, 1771-1776, Box 1, Folder 4, Joshua Burnham Papers, 1758-1817, Box 1 Shipping Papers, JDPL. By comparison, the earlier English migratory fishery at Newfoundland averaged over 20,000 fish on expeditions lasting 56-70 days. Pope, Fish Into Wine, 23.

${ }^{112}$ Vickers, Farmers and Fishermen, 100, 154, esp. Table 4.

${ }^{113}$ Boston Evening Post, November 28, 1763.

${ }^{114}$ Crawford, ed., The Autobiography of A Yankee Mariner, 16. 
schedule for as long as they stayed on the banks. ${ }^{115}$ Vickers estimates men worked 18-20 hours per day in the inshore fisheries, and "most of the day and frequently in turns throughout the night” in the offshore fisheries. ${ }^{116}$

Entire crews hand-lined for cod while working off shore. According to Prince, "when we come across a school of fish, every one is anxious to get as many as any of his shipmates.” Each man dropped two lines, usually thirty to fifty fathoms in length, over the vessel's bulwark and waited for the lead weights to carry the hooks and bait close to the ocean bottom where cod feed. They then anxiously lingered for a bite, and their patience was not always rewarded. The frustration of fishing unsuccessfully can be felt in Prince's words on the subject. He worked the Banquereau, or “Quero,” Bank off the east coast of Nova Scotia for two years, and later wrote:

At one time we came among a large quantity of fish, and they were hauling of them in, almost every one but myself, without any intermission, and I could not get one. If I felt a bite, it was only to rob my hooks of their bait, and sometimes I would hook one and get it near the top of the water and then it would break off. After experiencing many of these trials, which I bore for some time with Christian patience, I at last gave way and for the first time in all my life I uttered a profane word. ${ }^{117}$

A more fortunate fisherman hauled up his catch using wooden hand-frames and the bulwark for leverage. A single cod could weigh from five to a hundred pounds, and, in rare instances, could

\footnotetext{
115 John Groves and the crew of the schooner Nancy worked on the Grand Bank for 46 days between JulyAugust, 1795. Log of the schooner Nancy, 1795-1796, Ship’s Log Books, Microfilm \#91, Reel 3, JDPL. Skippers George Stevens and Thomas Woodberry, together with their respective crews worked on the Grand Bank for 52 days between June-August, 1770. Log of an unnamed schooner, 1774, George Stevens Logbooks, 1768-1774, MHS.

${ }^{116}$ Vickers, Farmers and Fishermen, 122, 150.

${ }^{117}$ Crawford, ed., The Autobiography of A Yankee Mariner, 16, 18. McFarland describes Banquereau as "another important fishing bank with an area of about 2,800 square miles." McFarland, A History of the New England Fisheries, 14. Prince further noted that "For many days I wept in private for what I had said. But not long after that I was several times placed in the same situation and repeated the same words without any remorse of conscience; and thus I continued again and again until it was done without a thought I had done wrong. I soon neglected prayer entirely and reading the Bible.” Ibid., 16-18. Thus, Prince blamed the nature of work in the commercial fishing industry for his impiety.
} 
exceed two hundred pounds. Cod tongues were taken out and separated for each of the more experienced men. Younger crew members cut the tails of fish with different marks, such as stumps, swallows, doubles, or singles, to indicate their catches. The marked and de-tongued cod was then tossed into a container nearby.

When the container began overflowing men stopped hauling cod out of the ocean and began processing the catch. Seventeenth-century cod fishermen did not have room in their smaller shallops to process the catch at sea. Instead, they were forced to take each haul to shore to be processed on stages, or short wharves located near chosen fishing grounds. Men such as Burnham and his crew, on the other hand, utilized the larger schooner as a floating stage. Part of the crew stood on the schooner's deck splitting cod bellies open, ripping out guts, cutting-off heads and tails, and then removing spines. The marked tails were presumably returned to their owner for the purposes of counting. Fishermen carefully removed the cod's liver to be converted into a lubricating oil for various machines, or "trains.” Hence, the name "train oil.” Other parts of the entrails were converted into bait. Workers, most probably the younger cuttails, also had the unsavory job of going down into the schooner's dank bowels to receive the filets. They lightly salted the filets and stacked them in the hold. This light salting was part one of a twostage curing process. The entire crew then repeated the process for as long as they were physically able, or until the schooner's hold had been filled. ${ }^{118}$

\footnotetext{
${ }^{118}$ Vickers, Farmers and Fishermen, 150-151, 173-174; quote taken from 150. The practice of sounding before fishing was routinely noted in the log books mentioned above in footnote \#104. For more on seventeenth-century fishing techniques in Massachusetts, including shore work on stages and the lower-limit for cod weight, see Ibid., 123-126. For the middling weight, see Head, Eighteenth Century Newfoundland, 5. For the upper limit of cod weight, see Innis, The Codfisheries, 4. According to Innis, cod “weight tends to grow less as one goes north" in the Atlantic Ocean. Ibid., 5. For more on seventeenth-century techniques in the English fishery at Newfoundland, see Pope, Fish Into Wine, 22-29, esp. Plate 2. Pope notes that the technology used in hand-lining for cod was medieval with the exception of the wooden hand-frames for winding the line. For the eighteenth century, see Head, Eighteenth Century Newfoundland, 72-74. For more on sixteenth and seventeenth century off-shore French techniques on the Grand Bank, see Innis, The Codfisheries, 48. Dories were not widely used in the cod fishing
} 
In essence, the eighteenth century schooner functioned as a floating factory. ${ }^{119}$ These hardy vessels were not merely used to transport workers to and from off-shore banks. Nor were they used exclusively to freight fish to markets. Schooners were utilized in these ways and more as workers began using the combination cure. The first component in the two-part curing technique involved beheading, gutting, boning, and lightly salting filets at sea on board the schooners. ${ }^{120}$ In this way, schooners represented work-spaces in a double sense. They aided in catching fish, which was part of the commercial process. In addition, schooners played an important role in the conversion of fresh fish into a saleable commodity, which was part of the manufacturing process that took place on the banks themselves.

Cod fishermen ran many physical risks working these off-shore banks to secure a commodity for their outfitting merchants. Even those born near the sea, such as Christopher Prince, needed time to season themselves to life and work on rolling waves and pitching decks. $^{121}$ Prince, who sailed out of Kingston, Massachusetts, recorded on his first fishing fare to unspecified "banks" off Nova Scotia that "after we passed the point ["the race point of Cape Cod”], I became so seasick I could not go off the deck, and I should not [have] struggled any if they hove me overboard!” He lay prostrate and ill on the schooner's deck “for three days.”122

industry until the nineteenth century. See, Andrew A. Rosenberg, W. Jeffrey Bolster, Karen E. Alexander, William B. Leavenworth, Andrew B. Cooper, and Matthew G. McKenzie, "The history of ocean resources: modeling cod biomass using historical records,” Frontiers in Ecology and the Environment, Vol.3, No.2, (2005), 85, Figure 1. The cod trap displaced hand-lining in the late nineteenth century. I am grateful to Daniel Finamore, Russell W. Knight Curator of Maritime Art and History at the Peabody Essex Museum, for providing me with a copy of this article. Pope, Fish Into Wine, 25n.

${ }^{119}$ Rediker has seen the merchant ship as a floating factory. Rediker, Between the Devil and the Deep Blue Sea, 83-87, 111-113.

${ }^{120}$ The second part, the drying, is described in a subsequent section here, and the combination cure is discussed further in chapter three.

${ }^{121}$ Vickers has argued that the reason fishermen and merchant mariners went to sea in the first place was that they had grown up near the ocean and work on the water was simply a natural part of life. Vickers, Young Men and the Sea. This might be the case. However, it still took time for young men such as Prince to get used to the ocean's nature and acclimatize himself to work upon the waves.

${ }^{122}$ Crawford, ed., The Autobiography of A Yankee Mariner, 14. 
The repetitive, laborious exertions needed to continuously pull heavy cod out of the depths more seriously wore on mortal bodies. Vickers has quantified the extent to which an individual cod fisherman's productivity declined at age thirty, following years of rigorous work. ${ }^{123}$ Workrelated accidents further took their toll on fishermen's bodies. Lovett recorded that while the crew of the schooner Volant was off the coast of Newfoundland on "Wednesday the $18^{\text {th }}$ Day of October 1769," fisherman "Paul Haskell Spl[it] the pan bone of his knee by falling with his [illegible] on fore Scuttle by a Sudden pitch of the Vessel.” The following day they "hove up and bore away to carry Paul Haskel home; and William Herrick is Lame, by putting his knee out of joint.” The constant and "sudden” movements of a wooden vessel on the ocean were enough to displace and even break a man’s bones. ${ }^{124}$ Such physical dangers explain why many fishing ports in Newfoundland maintained at least one surgeon in the eighteenth century, following the development of an off shore fishery there. ${ }^{125}$

Fishermen encountered all sorts of foul weather while working on the offshore banks of the Northwest Atlantic littoral that made their work that much more dangerous. Joshua Burnham, now working out of Gloucester for Daniel Rogers on the schooner Ruby, was fishing “on the Grand Bank” on Friday, September 19, 1788. Two days later, the Gloucester crew "hove up our anchor” and headed for Cape Anne. At 2 a.m. Tuesday, September 23, 91 leagues west of the Grand Bank, the Ruby was hit by "a hard Galle of wind at S.S.E” that forced the crew to reef sails. By 10 a.m. there was "wind at S. By W. hard Gale.” Twenty-four hours later, "the wind abated" and they headed "S.B.W. under 4 Reefed fore Sail.” According to the next observation

\footnotetext{
${ }^{123}$ Vickers, Farmers and Fishermen, 178-180, esp. Figure 2.

${ }^{124}$ For more on the separate but related dangers associated with inshore fishing, in which two or three men went out in a small vessel to catch fish on a short time schedule, see Vickers, Farmers and Fishermen, 124. Vickers notes that over 50\% of inshore fishermen that went to sea between 1645-1675 died in work-related accidents on the deep

${ }^{125}$ Trinity had five surgeons in the late eighteenth century. Jerry Bannister, The Rule of the Admirals: Law, Custom, and Naval Government in Newfoundland, 1699-1832 (Toronto: University of Toronto Press, 2003$), 147$.
} 
in Burnham's log, they were only 82 leagues west of the Grand Bank following the gale-force winds. ${ }^{126}$ John Thistle observed "thick weather" when he and his Beverly crew were "on the grand Bank” in mid-September, 1793. On the return to Massachusetts that same fare, Thistle "spoke with a Cape Ann man from the grand Bank. He had lost all of his cables and anchors" in a sudden storm, presumably related to the "thick weather" noted earlier. ${ }^{127}$ In 1769 George Stevens left Beverly on a spring fare to the Sable Island Bank. Near latitude $42^{\circ} \mathrm{N} 51^{\prime}$ and longitude $59^{\circ} \mathrm{W} 40^{\prime}$, southeast of Sable Island, on Wednesday March 4, Stevens observed 'this 24 [hours] past fine winds and Cloudy weather with Some Squalls of Snow.” On Thursday, March 5: “This 24 past moderate breeze of wind and Clear weather.” Then, near latitude $43^{\circ} \mathrm{N}$ $21^{\prime}$ and longitude $59^{\circ} \mathrm{W} 10^{\prime}$, he encountered "rainy weather." Later, on the return trip back to Beverly, at latitude $39^{\circ} \mathrm{N} 23^{\prime}$ and longitude $68^{\circ} \mathrm{W} 47^{\prime}$, he observed 'these 24 [hours] past hard winds so that we was obliged to Scud."128 Afterward, Stevens and his company set sail from Beverly to Banquereau Bank on a first fare in April 1774. The men only caught "some" cod there, however, and they put-off for the Grand Bank at the end of the month. En route, Stevens observed "fresh gales with plenty of rain and Cold Weather." At another time, on a fall fare to Banquereau Bank in mid-August, he observed "foggy, misty weather."129 According to Vickers, adverse climactic conditions cost colonial fishermen "one to three full days" of work each week during the eighteenth century. ${ }^{130}$ One horrified English migratory fisherman attempting an early trip to the Grand Bank in March, 1670 observed artic winds and waters that turned his vessel into “a lump of ice....the water freezes as soon as it comes on decks, not for our lives able to loose a

\footnotetext{
${ }^{126}$ Log of the schooner Ruby, 1788, Ship’s Log Books, Microfilm \#91, Reel 68, JDPL.

${ }^{127}$ Log of the schooner St. Peter, 1793, Ship’s Log Books, Microfilm \#91, Reel 68, JDPL.

${ }^{128}$ Log of an unnamed schooner, 1769, George Stevens Logbooks, 1768-1774, MHS.

${ }^{129}$ Log of an unnamed schooner, 1774, George Stevens Logbooks, 1768-1774, MHS.

${ }^{130}$ Vickers, Farmers and Fishermen, 122.
} 
knot of sail, all things are so frozen....God help us, we are very fearful.”131 As late as May, Newfoundland merchant Samuel Prince encountered "nothing but hard gales \& contrary winds \& snow storms the chief of our passage" from Boston to St. Johns. "For my part," he wrote to Boston merchant Isaac Clarke, "I began to think we had mistaken the season of the year \& left Boston in January instead of May, so much for our passage.”132

Such bad weather contributed in different ways to the work-related dangers fishermen faced. Several newspapers in New England reported in 1766 the effects of storms at sea on various sailors and fishermen. Included in these accounts was the description of "the Bodies of two Men” that had washed up on the shore off Sable Island near the wreck of a schooner, "which by their Dress appeared to be Fishermen.”133 A Worcester, Massachusetts newspaper reported hearing from Boston of a "violent storm of the $19^{\text {th }}$ of November, 1783. "Since which several other dead bodies have been taken up, which appear to be fishermen.”134 Shipwreck could also occur as a result of collision, usually when larger vessels failed to spot fishing vessels moored on the banks at night. ${ }^{135}$ Accounts of drowned fishermen were never big news, meriting only a few sentences in the back pages of newspapers. Yet, such accounts were not uncommon. ${ }^{136}$ Men were also reported "lost” or “drowned” while working on the offshore banks in vital records pertaining to deaths. ${ }^{137}$ Between January, 1768 and June, 1770, “Twenty-four” fishing vessels

${ }^{131}$ Quote taken from Head, Eighteenth Century Newfoundland, 2. For a later first-hand account of fishermen encountering ice-flows on the Grand Bank in 1726, see Ibid., 73.

${ }^{132}$ Letter from Samuel Prince to Isaac Clarke, dated Trinity, Newfoundland, June 21, 1766, MHS.

${ }^{133}$ Boston Evening Post, June 23, 1766; The Boston News-Letter and New-England Chronicle, June 26, 1766; Connecticut Courant, June 30, 1766.

${ }^{134}$ Massachusetts Spy; Or, Worcester Gazette, December 4, 1783.

135 The Boston Gazette, and Country Journal, July 18, 1763; and Boston Evening Post, July 18, 1763; The Newport Mercury, July 25, 1763.

${ }^{136}$ In addition to the accounts in this paragraph, see Boston Post Boy, September 10, 1764; and New-London Gazette, October 8, 1773.

${ }^{137}$ For Aaron Burnham’s drowning in 1782, see footnote \#25 above. Also, see the death record for John Chin, Marblehead fisherman. Chin was “washed over[board] in [a] spring fare,” in 1745. EVREC, Vol. 2, 515. Similar examples of Marblehead fishermen’s deaths for a later period include Charles Chadwick, who "Sailed in August last 
from Marblehead alone, along with "One hundred and seventy Men and Boys," were "lost at Sea.”138 Outfitting merchants may have risked a large amount of capital in fishing expeditions. However, workers risked life and limb - especially in bad conditions.

The work of deep-sea fishing impacted laborers not only physically, but psychologically as well. Vickers has emphasized the ways in which gloomy weather and physical separation from family members generated a sense of isolation and melancholy loneliness among colonial fishermen. ${ }^{139}$ To be sure, most skippers were separated from their family members, and fishermen in general probably felt the dreary effects of inclement weather more than others. Yet, there were strong kinship ties among crewmembers that may have mitigated separation anxieties.

In addition, there are other reasons to believe the psychological effects of deep-sea fishing, particularly with regard to loneliness, have been overestimated. For example, there was a fairly constant circulation of knowledge among eighteenth-century fishing fleets regarding how long a crew had been at sea, where they had worked, and how much fish they had caught. ${ }^{140}$ When John Groves and the crew of the Danvers schooner Nancy were not taking soundings on the Grand Bank in 1795, they "Saw and spoke” with "several” other fishing vessels. "No fish on the Bank was all the News then Extant," Groves reported. ${ }^{141}$ On a fall fare to Canso Bay off the

in a Schooner belonging to Mr. Samuel Knight for the Grand Bank and never been heard of Since,” in 1815. John Courtis was also on Knight's schooner. Ibid., 524. One of Chadwick's relations, another Charles, "Drowned on Grand Bank, Schooner Senator," in 1846. Ibid., 512. Isaac Collyer was "lost at Sea Coming from Grand Bank last September (Schooner Susan), in 1825. Ibid., 521. William Cole "and company, lost going to Grand Bank (Schooner Panther)," in 1830. Ibid., 520. William Chambers was "Lost Overboard out of the Schooner

(Friendship), Samuel Thompson, Skipper, on Grand Bank” in 1831. Ibid., 513. John William Caswell was "one of the Crew of the Schooner Ocean lost on the passage from the Grand Bank" in 1840. Ibid., 511. One of his relations, Thomas P. Caswell, “drowned on Grand Bank, Schooner Zela,” in 1846. Ibid., 512.

${ }^{138}$ By the Honorable Thomas Hutchinson... (Boston: Richard Draper, 1770), Early American Imprints, Series I: Evans \#42125.

${ }^{139}$ Vickers, Farmers and Fishermen, 181-182.

${ }^{140}$ For evidence of this circulation of knowledge in the nineteenth-century fishing industry, see Rosenberg, Bolster, Alexander, Leavenworth, Cooper, and McKenzie, "The history of ocean resources: modeling cod biomass using historical records," Frontiers in Ecology and the Environment, 84-90.

${ }^{141}$ Log of the schooner Nancy, 1795-1796, Ship’s Log Books, Microfilm \#91, Reel 3, JDPL. 
coast of Maine, on Oct. 27, 1796, Groves "spoke Joseph Woodbury [in the] schooner Rachel.” Woodbury, who was returning from Canso, reported having 23,000 fish on board. Three days later, the Nancy's skipper “spoke Nathaniel Black, Bound home” with 32,000 fish. ${ }^{142}$ While on the Grand Bank in late April, 1774, George Stevens observed "Saw a Ship to the Southward; Saw two Marblehead men; Spoke with one of them; He told us he had been from home Six weeks and had a hundred quintals of fish."143

In addition, colonial Massachusetts skippers frequently "saw" and "spoke” with other vessels on their journeys across well-traveled Atlantic shipping lanes. In a particularly detailed log, John Lovett, skipper of the schooner Volant, sailed from Cape Ann to Sable Island and then on to Banquereau Bank between April 23-28, 1769. On four of the six sailing days to the Bank the skipper spoke with other vessels. For three of the six days they sailed in company with another schooner. He observed "at 9 of the Clock Saw S[to the south?] Sail of Schooners bound to the eastward." They then "veered out to the Eastward and Joseph Lovett and [?] Cox in Company with us." When he and his crew reached the Banquereau Bank, which lay "to the eastward” of the Sable Island Bank, Lovett observed "Spoke with a Cape Anne man.” One day later, he "Spoke With a Cape Ann Man" a second time in as many days. They then fished for one month. Between June 1-7, Lovett and his crew sailed home from Banquereau Bank. On 6 of the 7 days the skipper spoke with other vessels. On his way home to Cape Ann, he observed "spoke with small schooner belonged to Cape Anne and bound to the [Sable] island." Later, he observed "saw a Marblehead fisherman and Spoke with him and he told us that there Was thirteen or fourteen Sail of their fishermen Lost [as a result of a storm] as they thought.” On the following day, "Saw Several Sails of Schooners Laying away a-fishing, and Spoke with one

\footnotetext{
${ }^{142}$ Log of the schooner Nancy, 1795-1796, Ship’s Log Books, Microfilm \#91, Reel 3, JDPL.

${ }^{143} \log$ of an unnamed schooner, 1774, George Stevens Logbooks, 1768-1774, MHS.
} 
Marblehead man.” The next day, located in Longitude 65:56, Latitude 43:05, Lovett even stopped to give a "Cutthroat," a knife used by fishermen to filet cod, to "John Bridgum of Marblehead.” The day after, he "Saw two sails of Vessels." Then, Lovett "Spoke With Samuel Woodbury." 144 Thus, 10 of the 13 days sailing time involved in this fishing fare involved contact with men beyond the crew of the Volant. Massachusetts fishermen even met maritime laborers on the banks who were en route from other countries, even as far as Russia. ${ }^{145}$ Of course, it is possible that the majority of crews were busy about their work and they did not fraternize during these encounters. Yet, even if crewmembers kept their mouths closed and never socialized with fellow seafarers while their skippers exchanged information, the sight of other mortals navigating the deep combined with the proximity of other vessels and people from Massachusetts surely provided some emotional comfort.

Fishermen frequently left ports to go out on fares "in company" with other vessels. In 1770, George Stevens left Beverly on a spring fare to an unspecified "Bank" with "Iccabod Groves in Company with us." Stevens then went on a summer fare "Thomas Woodberry in Company with us.” Together, Woodberry's vessel and Stevens' vessel worked waters around Maine’s Canso Bay and then off “the North Side” of St. John’s, Newfoundland. Combined, the two fishing crews caught 55,903 fish. For the final fall fare in September, the Beverly skipper went to Banquereau Bank, "Joseph Lovett in Company With us."146 Later, on a 1774 spring fare, Stevens sailed from Beverly to Banquereau Bank, "with Jonathan Larkum, Commander of

\footnotetext{
${ }^{144}$ Log of the schooner Volant, 1769, George Stevens Logbooks, 1768-1774, MHS.

${ }^{145}$ Log of the schooner Nancy, 1795-1796, Ship’s Log Books, Microfilm \#91, Reel 3, JDPL. On the way home from the Grand Bank, John Groves observed: "spoke the William of Salem, Captain Benjamin Bickford from Russia 76 days out." While returning from the Grand Bank, John Thistle observed on Friday, November 2, 1793: "spoke with a brig from Malaga, [Spain] bound to Boston.” Then, on their way from Beverly to the Grand Bank on Saturday, September 7, 1793, Thistle made contact with "two Manchester [England] schooners.” Log of the schooner St. Peter, 1793, Ship’s Log Books, Microfilm \#91, Reel 68, JDPL.

${ }^{146}$ Log of an unnamed schooner, 1770, George Stevens Logbooks, 1768-1774, MHS.
} 
Schooner Benjamin.” Stevens must not have had much luck in the area, for the Beverly skipper soon left the Banquereau Bank for the Grand Bank. This time, Stevens recorded, "Samuel Masury in Company.”"147 Apparently, Stevens and Masury commiserated on Banquereau and decided to try their luck at the Grand Bank. For his part, Larkum and his crew did not join the two vessels as they headed eastward. Asa Woodbury, skipper of the schooner Lark, left Beverly on a spring fare to "the Western Ground” of an undisclosed off-shore bank, "Jonathan Larkum in Company With us.” One "evening,” Woodbury "Spoke with John Wallis,” who was on another fishing vessel. The following summer fare, Woodbury left Beverly in late June and "got up to St. John's Newfoundland; John Wallis in Company.” Clearly, Woodbury and Wallis were on close enough terms to speak and work together. Off the coast of Newfoundland, near "Matleen Island," the two skippers "Saw several other Vessels a fishing."148

In sum, commercial cod fishing does not seem to have been a very lonely occupation in the eighteenth century. Sharesmen and cuttails would have had family members on board with them, and these kinship ties would have helped ameliorate home sickness. The documented conversations between skippers provided them with some fraternization at sea. Within welltraveled shipping lanes, and on common fishing grounds, the near constant proximity of other crews and familiar vessel names would have served as physical reminders of home. In addition, colonial crews occasionally went to sea in fleets, literally in company with their fellow town members. These factors certainly mitigated the isolation of work at sea.

${ }^{147}$ Log of an unnamed schooner, 1774, George Stevens Logbooks, 1768-1774, MHS.
${ }^{148}$ Log of the schooner Lark, 1771, George Stevens Logbooks, 1768-1774, MHS. 
On Saturday July 16, the crew of the Polly weighed anchor and "sailed from the Grand Banks for home.”149 Assuming they encountered good weather, their return trip would have been one week longer than their voyage out, seventeen days on average, due to contrary westerly winds. ${ }^{150}$ In total, then, fishermen traveling to and from the Grand Banks in the late eighteenth century could expect almost a month of sailing time.

Time was a crucial element in processing raw fish and getting it to market. Early modern fishermen were governed by the pressures of the marketplace every bit as much as urban industrial workers, if not more so due to the perishable nature of their particular commodity. ${ }^{151}$ In an age lacking refrigerated holds, cod flesh taken out of the ocean began to decompose almost as soon as it was removed from the ocean. Fishermen salted cod filets at sea in order to delay this natural process. They then waited for a full hold before leaving the offshore banks and heading home to finish the curing process. This delay, coupled with carrying times, placed great pressure on fishermen to catch, process, pack, and transport cod to home ports as quickly as possible. Fishermen's earnings were directly tied to the price their catch could command in the marketplace. More will be said about these earnings shortly, but spring fare merchantable grade

\footnotetext{
${ }^{149}$ Schooner Polly, 1771-1776, Box 1, Folder 4, Joshua Burnham Papers, 1758-1817, Box 1 Shipping Papers, JDPL.

${ }^{150}$ The average sailing time from the Grand Bank to Beverly, Massachusetts in the late eighteenth century was taken from the log of the schooner St. Peter, 1793, Ship's Log Books, Microfilm \#91, Reel 68, JDPL; the log of the schooner Nancy, 1795-1796, Ship's Log Books, Microfilm \#91, Reel 3, JDPL; the log of the schooner Lark, 1771, George Stevens Logbooks, 1768-1774, MHS; and the log of an unnamed schooner, 1774, George Stevens Logbooks, 1768-1774, MHS. Again, by way of comparison, the West Country migratory fishing fleets routinely faced homeward bound travel times of three weeks. Steele, The English Atlantic, 82. In sum, it took the fleets that sailed out of England longer to reach Newfoundland than it did to sail home. The opposite was the case for New England fishermen, due primarily to wind speeds and ocean current direction.

${ }^{151}$ Vickers, Farmers and Fishermen, 117, 119-123, 127; Pope, Fish Into Wine, 171-172; and Fernand Braudel, The Structures of Everyday Life: Civilization \& Capitalism, $15^{\text {th }}-18^{\text {th }}$ Century, Volume 1, translated by Siân Reynolds, (New York: Harper \& Row, Publishers, 1979), 217. According to Braudel, as early as the sixteenth century French cod fishermen in Olonne, near La Rochelle, engaged in a "race" every year to see which crew could make a fare to the Grand Bank and return the quickest. "The winning captain," Braudel writes, could earn "as much as 60 livres” for every quintal, while those selling their fish thereafter stood to make only "30 livres."
} 
dried cod typically commanded the best prices on an annual basis. ${ }^{152}$ Fish caught in colder weather tended to stay fresh for longer periods of time. Those who could not get to the banks early could make up for this with additional trips. As a result, fishermen raced to get to off-shore grounds first, and most often, each year. Moreover, such time-related pressure did not abate as the year progressed. For, if markets became glutted, then prices could decline rapidly. Thus, there could be a near constant demand to get as much fish as possible to market as quickly as possible. On November 14, 1795, the schooner Nancy weighed anchor and "sailed from Grand Bank Bound for Beverly.” Skipper John Groves prayed "God send us a fast passage to our Destined port.” Despite the weather and work-related accidents that could hinder his passage, he did not pray for safe passage home. Even late in the year, speed mattered most to those fishermen seeking the best prices, and thereby the best earnings with which to feed families. ${ }^{153}$ If there was any negative psychological effect linked specifically to commercial fishing in the Age of Sail, then it was surely the stress associated with the time discipline that was part-andparcel of even this early modern industry. ${ }^{154}$

${ }^{152}$ Daniel Vickers, "The Price of Fish: A Price Index for Cod, 1505-1892," Acadiensis, Vol. 25, No. 2 (Spring, 1996), 62-81.

${ }_{153}$ Schooner Nancy, 1795-1796, Ship’s Log Books, Microfilm \#91, Reel 3, JDPL. Emphasis my own.

${ }^{154}$ For more on the relationship between time management and modern, capitalistic, commercial enterprise, see E.P. Thompson, Customs in Common: Studies in Traditional Popular Culture (New York: The New Press, 1992), esp. ch. 6, "Time, Work-Discipline and Industrial Capitalism,” 352-403. Thompson argued that "fishing and seafaring peoples" maintained "a disregard for clock time," as opposed to urban industrial laborers. Ibid., 357. His interpretation on this score may reflect a broader view of English working peoples as politically backward-thinking, or "inarticulate," prior to the turn of the nineteenth century. For more on this view, see his seminal work, The Making of the English Working Class (London: Gollancz, 1963), quote taken from 85. 


\subsection{BACK IN PORT}

Once Burnham and his company returned to Ipswich from their summer fare, the 11,262 cod they took would have been unloaded in order to complete the drying process. In the seventeenth century, fishermen would have built flakes, open-air wooden platforms, for air-drying the fish on some shoreline near their preferred fishing waters. ${ }^{155}$ In the eighteenth century, by contrast, workers using the combination cure air dried the cod filets that had been processed at sea back at their home port. On the docks, carters and day laborers in the outfitting merchant's employ carried the wet-salted fish filets and cod livers that had been packed in hogsheads to the merchant's flakeyard. These yards typically included all the elements necessary for dry-curing cod: flakes or fences, train vats, fish houses and nearby warehouses. Train vats were large containers in which shoremen rendered cod livers into oil, which then spilled through spouts into barrels. ${ }^{156}$ Fishermen used a fish house to pile dried cod in stacks. Weighted down, any additional moisture was squeezed from the fish. ${ }^{157}$ After the filets had dried properly, they were packed and salted in hogsheads and stored in warehouses until they were loaded onto vessels for overseas transport.

Merchants could own and maintain all of these means of production - ships, flakes, warehouses, or they could rely on independent contractors. In 1773, Marblehead merchant William Knight paid a fee to Archibald Selman to use his fish house "for drying." At various other times, Knight rented fences "for drying” from neighbors Abigail Orne, Jane Bray, and

\footnotetext{
${ }^{155}$ Vickers only describes the labor involved in drying cod during the seventeenth century. Vickers, Farmers and Fishermen, 124-126. He does not discuss the ways in which the drying process changed as a result of the shift toward schooners and the combination cure beyond noting that schooners "functioned as a floating stage." Ibid., 150 .

${ }^{156}$ Head, Eighteenth Century Newfoundland, 3-4, esp. Figure 1.1.

${ }^{157}$ A picture of an early-twentieth century fish house filled with cod stacks can be found in Albert Cook Church, American Fishermen (New York: W.W. Norton \& Company, Inc., 1940), picture 210.
} 
Captain William Courtis. On additional occasions, Knight charged "drying” fees for use of his flakeyard and rental fees for "hiring" his fish flakes. ${ }^{158}$ Idle means of production meant reduced profits.

At the flakeyard, shoremen, who could be the merchants themselves or paid employees, were in charge of processing cod livers in vats and properly drying the filets on fish flakes. The cod was to be turned flesh side up during the day in sunshine and skin side up at night or during rain, as too much moisture could ruin the curing process. ${ }^{159}$ The method had its imperfections. Too-lightly salted portions of the catch habitually rotted on the return voyage and filets improperly dried spoiled. The process therefore yielded filets that had to be sorted according to their saleable quality.

Once the filets had been completely cured, the outfitting merchant employed a culler to separate the dried cod into the merchantable grade, or the freshest, most properly dried fish; the refuse, or Jamaica, grade, the most rotten fish still deemed eatable; and a middling grade in between the two extremes. Francis Felton culled fish for Marblehead merchant William Knight between 1769-1774. Felton charged Knight three shillings five pence to cull 82.5 quintals of fish in November 1771; three shillings nine pence to cull 90 quintals of fish on June 30, 1772; three shillings eleven pence to cull 94.75 quintals of fish on December 8, 1773; and five pence to cull 10.5 quintals of fish on July 20, 1774. Given that a quintal equaled 112 lbs. dry weight, Felton earned one pence to separate two quintals, or $224 \mathrm{lbs}$. of dried cod, between 1771 and $1774 .{ }^{160}$ John Bickford culled fish for Salem merchant Timothy Orne between 1764 and 1767. In 1767,

\footnotetext{
${ }^{158}$ William Knight Account Book, 1767-1781, JDPL.

${ }^{159}$ The duties of shoremen in this regard did not change between the seventeenth and the twentieth centuries. For the seventeenth century practice, see Vickers, Farmers and Fishermen, 125. For the early twentieth century, see Church, American Fishermen, pictures 211 and 212.

${ }^{160}$ William Knight Account Book, 1767-1781, JDPL.
} 
Bickford earned $£ 0.10 .5$ for culling 250 quintals of fish, which amounted to the same earnings as Felton in Marblehead some years later. ${ }^{161}$

On occasion culling was not contracted out. Independent fishermen (men who owned their own small boats, worked alone, and sold fish to merchants in exchange for goods and lines of credit) typically culled their own fish. John Standly culled his own fish before selling it to William Knight in 1771. Standly then charged Knight for culling services in addition to the fee for the fish. Benjamin Darling did likewise in 1772, as did Phillip Goudy and Benjamin Ashton one year later. ${ }^{162}$ Thomas Rand culled and sold fish to Gloucester merchant Daniel Rogers in $1771 .{ }^{163}$

At other times, outfitting merchants culled fish themselves. Knight sold merchantable and Jamaica grades to Thomas Gerry, Jr., between 1772 and 1774. Knight, like Standly, charged for culling fees in addition to the fish fee. He also culled and sold fish to Robert Hooper in 1772. One year later, he culled and sold merchantable and Jamaica grades to Captain John Prince. ${ }^{164}$ In this manner, Knight lowered his operating costs and thereby raised his profit margin.

Separated grades of fish were then weighed before being sold. Some outfitters did their own weighing. John Standly sold Jamaica and merchantable fall fare to William Knight in 1770, and Knight charged him £0.1.6 per quintal to "weigh \& Labor" 144.75 quintals. Joseph Abbot, another independent Marblehead fisherman, sold his catches to Knight between 1770 and 1773,

\footnotetext{
161 Timothy Orne Ledgers, 1762-1767, JDPL. According to Vickers, refuse grade cod included "cod that was broken, undersized, over-salted, left out in the rain, or damaged in any other way," while merchantable cod was “properly split and cured.” Vickers, Farmers and Fishermen, 99.

${ }^{162}$ William Knight Account Book, 1767-1781, JDPL.

163 Daniel Rogers Account Book, 1770-1790, JDPL.

${ }^{164}$ William Knight Account Book, 1767-1781, JDPL.
} 
and Knight charged him similar fees to weigh the fish. ${ }^{165}$ Captain John Reed bought 36 quintals from Marblehead merchant Richard Pedrick in July and November, 1771, and paid Pedrick a fee for weighing each time. Joel Smith, John Carder and Captain Thomas Proctor did likewise in $1774{ }^{166}$

Fish merchants could also contract out their weighing services. In addition to culling fish, Felton weighed fish for Knight during the late 1760s and early 1770s. John Bray, an independent Marblehead fisherman, sold his catches to Knight between 1771 and 1772 . Unlike Joseph Abbot, Bray weighed the fish himself and charged Knight £0.2.1 for 16 quintals. ${ }^{167}$ John Brown sold Marblehead merchant Thomas Pedrick thirty-four quintals of merchantable fall fare and thirty-five quintals of Jamaica grade in 1774, and he charged Pedrick for weighing services rendered. John Cauley, John Bray, Samuel Chin and Philip and William Ashton did likewise. ${ }^{168}$

Once the outfitting merchant knew how much and what type of fish he had to sell, as well as the current market price of each grade, a total value was placed on the catch. At that point, the crew and the merchant sat down to reach a financial settlement. If dried cod was in great demand in overseas markets (which was known principally through correspondence between merchants and through the reports of returning ship captains) and it could fetch a high price, the value of catches and worker's earnings were adjusted accordingly. ${ }^{169}$ That is to say, these earnings would only be adjusted if workers operated on a share system. Any left-over great general goods would be returned to the merchant. The total cost of the small general goods for each fare would be divided among the crew and charged to their accounts. If barrels of oil had

\footnotetext{
${ }^{165}$ William Knight Account Book, 1767-1781, JDPL.

${ }^{166}$ Richard Pedrick Account book, 1767-1784, MDHS.

${ }^{167}$ William Knight Account Book, 1767-1781, JDPL.

${ }^{168}$ Thomas Pedrick Account Book, 1760-1790, MDHS.

${ }^{169}$ Vickers, "The Price of Fish: A Price Index for Cod, 1505-1892," 196.
} 
been processed, each man would receive a share of the overall value of the oil. In each annual settlement involving a share system, the fishing company's portion of the value of the fish caught on each fare typically amounted to five-eighths. ${ }^{170}$ This five-eighths was then divided equally among the sharesmen in the fishing company, regardless of how many fish each man actually caught. Their equivalent fish counts represented the vernacular calibration of rank, age, and experience. $^{171}$

At times, fishing crews went to sea on the count system. ${ }^{172}$ In this less customary, more capitalistic mode of labor discipline workers were given pre-arranged pay rates based on the number of fish caught. Usually, men agreed on a rate per every thousand fish caught. For example, Gloucester merchant John Stevens paid John Perry £19.12.10 for 3,272 fish caught on a single fare at $£ 6$ per thousand fish in $1771 .{ }^{173}$ In a rare instance in which the count system terms were contractually recorded, Gloucester merchant Ezekiel Woodward, Jr. agreed in 1762 to "Engage to Give Joshua Burnham Six Pounds Thirteen Shillings and 4 [pence] for Each Thousand of Cod fish said Burnham Shall Catch on Board my Schooner [Abigail] this fall fare on the Banks \& Bring home." ${ }^{\text {174 }}$ Burnham and the crew of the Polly operated on a count system when they went to the Grand Bank in $1774 .{ }^{175}$ Such a system encouraged an ethic of aggressive competition among fishermen and can be seen as a form of piece-work waged labor, as workers effectively engaged in a wage agreement with merchants. Moreover, customary distinctions with respect to earnings between skilled and unskilled labor virtually evaporated on the count system.

\footnotetext{
${ }^{170}$ Vickers, Farmers and Fishermen, 161.

${ }^{171}$ There were five sharesmen and only two cuttails on board the schooner Esther, Benjamin Henderson, skipper, during a fall fare in 1760 . The reported fish count, as opposed to the actual fish count, was that the skipper and one other man caught exactly 2,419 cod; the remaining three sharesmen each caught precisely 2,418; and the cuttails caught 1,860 and 1,524 each. Timothy Orne Ledgers, 1762-1767, JDPL.

${ }^{172}$ Vickers, Farmers and Fishermen, 161-162.

173 John Stevens Account Book, 1769-75, JDPL.

${ }^{174}$ Joshua Burnham Papers, 1758-1817, Schooner Abigail, [c.1762], Box 1, Folder 1, JDPL.

175 Joshua Burnham Papers, 1758-1817, Schooner Polly, 1771-1776, Box 1, Folder 4, JDPL.
} 
If one man worked hard and got lucky he could catch a lot of fish and make more than another laborer, regardless of age or experience. The only difference among the men at the start of the expedition was the fact that the skipper maintained the aforementioned additional responsibilities.

Neither system benefited all workers equally. The share system privileged age over competency, while the count system ignored more customary benefits associated with seniority and tenure. However, workers in the eighteenth century Massachusetts cod fishing industry preferred these two systems to "straight" wage labor. ${ }^{176}$

Workers in the cod fisheries did not typically earn straight wages during the eighteenth century. There is modest evidence that such wages were introduced at Robert Trelawny's failed attempt to establish a permanent resident fishing station at Richmond Island off the coast of Maine in the mid-seventeenth century. ${ }^{177}$ There is also evidence that John Stevens attempted to introduce straight wage labor among his Gloucester workers in the second half of the eighteenth century. ${ }^{178}$ Yet, for the most part cod fishermen had an aversion to straight wage labor. ${ }^{179}$ Such

\footnotetext{
${ }^{176}$ A "straight" wage system in the commercial fishing industry involved a flat payment for labor that disregarded the number of fish caught.

${ }^{177}$ Pope, Fish Into Wine, 190-191. Pope ingeniously demonstrates the ways in which Trelawny's fishermen equated these wages with portage, or private venture they would have received in the migratory fishery. In other words, the early workers felt they were being compensated for not getting the chance to sell any venture on the return trip to England. Pope argues that such logic originated the term portledge bill for a waged agreement.

${ }^{178}$ John Stevens paid Gideon Carter "wages” for a trip "to the Banks with Phillip Babson” in 1770. David Walles, Jr., deposited in an account with Stevens his "Wages to the Banks" with John Derry Skipper at an unidentifiable date. See, John Stevens Account Book, 1769-75, JDPL.

${ }^{179}$ Pope, Fish Into Wine, 185, 188-189. Vickers writes that during the eighteenth century "free market relations" between labor and capital in the cod fisheries had "supplanted" more traditional relations. Vickers, Farmers and Fishermen, 203. But, he is careful not to define these "free market relations" as specifically waged labor, nor does he dispute the fact that fishermen preferred the share system above all else. For bold, yet unsubstantiated, claims that the Newfoundland cod fishing industry converted completely to wage labor by the mideighteenth century, see Innis, The Codfisheries, 151-152; and Lounsbury, The British Fishery at Newfoundland 1634-1763, 90.
} 
antipathy was common among workers in other early modern industries. ${ }^{180}$ In order of usage, then, workers in the eighteenth century cod fishing industry went on the share system, the count system, and straight wages. ${ }^{181}$

Each form of payment represented a verbal or written contractual means by which merchants could discipline workers in the fishing industry. The share and count systems, for example, gave workers a financial incentive to work hard and bring the fish into port as fast as possible. More fish caught quickly meant higher prices and better profits for sharesmen, and those who went to sea "on the count" earned just as much money as they could catch fish. The straight wage, on the other hand, stripped workers of any incentive to work hard or quickly. Whether they turned in a hundred cod or a thousand, fishermen received the same fixed wages. Straight wages did offer workers some protection from broken voyages and more predictable income, however, and straight wages appealed to those merchants in populous areas who were able to hire workers cheaply and thereby increase their profit margins.

The actual earnings fishermen made varied depending on which pay system was employed, the number of fish caught (which depended on a host of variables), and the price of cod. However, on average, between 1750 and 1775, older, experienced hands typically earned $£ 10$ - 20 per fare, three fares a year, while younger lads averaged $£ 5-£ 10$ per fare. ${ }^{182}$ Put another way, commercial cod fishermen could earn between $£ 15-£ 60$ for work in the spring, summer, and fall. By comparison, men who worked as merchant mariners on trade ships typically earned

${ }^{180}$ Christopher Hill, "Pottage for Freeborn Englishmen: Attitudes to Wage-labour,” in Hill, Change and Continuity in Seventeenth-Century England (London: Weidenfeld and Nicolson, 1974), 219-238.

${ }^{181}$ This point represents a departure from McFarland and is more in line with Vickers. See, McFarland, A History of the New England Fisheries, 96-97; and Vickers, Farmers and Fishermen, 162, esp. footnote \#31.

${ }^{182}$ Average earnings taken from sources listed above in footnotes 34-43. 
between $£ 1.14 .0-£ 2.18 .0$ per month. ${ }^{183}$ In Salem, Massachusetts in 1753, just before the Seven Years’ War, masters of schooners on trading missions earned £1.17.4 per month; mates £1.12.0; and mariners £1.6.8. ${ }^{184}$ In Ipswich, Massachusetts in 1774, on the eve of the Revolutionary War, similar masters earned £2.8.0 per month; mates £1.12.0; and mariners £1.6.8. ${ }^{185}$ For their part, waterfront workers such as carpenters earned around $£ 1$ per month. ${ }^{186}$ In general, between 17501775, workers in colonial America earned £8-£40 annually, or £0.13.4-£3.6.8 per month. ${ }^{187}$ Fishermen, then, earned slightly more on a yearly basis for catching cod than other laborers. A small comfort when the labors and dangers affiliated with off-shore banks fishing are taken into account.

Burnham and the crew of the Polly did not reach a financial settlement with the Choats immediately after the summer fare in 1774 . The drying, culling, weighing and pricing took time, typically five to six weeks to properly cure the catch. ${ }^{188}$ Such a processing time effectively prevented fishermen from collecting earnings after each fare. For, if they waited on shore during this time, then they could not go to sea to catch more fish. Only during the winter months, when fishing fares were far less likely, could labor and capital take stock and come to a settlement. As a result, fishermen were usually paid for their labors on an annual basis, typically in the first part of the year. Marblehead outfitter William Knight routinely settled accounts in January and February. ${ }^{189}$ Gloucester outfitter John Stevens settled accounts with his fishermen in February

${ }^{183}$ Nash, Urban Crucible, Figure 6, 414.

${ }^{184}$ Schooner Molly, 1751-57, Box 7, Folder 10, Timothy Orne Shipping Papers, JDPL.

${ }^{185}$ Schooner Polly, 1771-1776, Box 1, Folder 4, Joshua Burnham Papers, 1758-1817, JDPL.

${ }^{186}$ Nash, Urban Crucible, 323.

${ }^{187}$ Nash, Urban Crucible, Figure 7, 415. Here it is assumed that the figures for the "lower 50 percent of decedents" pertained to workers.

${ }^{188}$ See, Letter from William Poyntz to the Lords Commissioners of Trade and Plantations, dated Lisbon, September 17, 1718, NA SP 89/26/78A.

${ }^{189}$ William Knight Account Book, 1767-1781, JDPL. 
and March of every year. ${ }^{190}$ Gloucester outfitter Ezekiel Woodward, Jr. did contract with Joshua Burnham "to Pay him in Cash in Twenty Days after he Comes home" following the "fall fare on the Banks" onboard the schooner Abigail in 1762. ${ }^{191}$ But such an arrangement was outside the norm.

In the intervening months between financial settlements, merchants allowed laborers to buy goods on credit against their future earnings. Workers in the commercial cod fishing industry typically bought goods for themselves such as rum, cider, spending cash, and various types of food, including molasses, bread, pork, sugar and tea. They also purchased items for their wives or mothers, including silk handkerchiefs, chocolate, coffee, flour and additional spending cash. ${ }^{192}$ In the seventeenth century, credit was offered on easy terms and rarely sought after. Yet, as the industry became increasingly capitalistic in the eighteenth century merchants became less willing to extend long-term and interest-free credit. They also began suing debtors on a much more frequent basis. ${ }^{193}$

The commercial cod fishing industry became increasingly capitalistic in the eighteenth century due principally to the fact that ownership of the means of production had shifted decisively into the hands of a few merchants. For the most part, there were two essential productive means in the commercial cod fisheries: vessels, primarily schooners in the eighteenth century, and flakeyards. The schooner was necessary for mining oceanic depths and beginning the process of converting raw catches into saleable commodities. In the seventeenth century, $40 \%$ of cod fishermen owned at least a share in fishing vessels. In the years before the American

\footnotetext{
190 John Stevens Account Book, 1769-75, JDPL.

191 Joshua Burnham Papers, 1758-1817, Schooner Abigail, [c.1762], Box 1, Folder 1, JDPL.

${ }^{192}$ William Knight's ledger is particularly detailed on the consumer culture among fishing families. See, William Knight Account Book, 1767-1781, JDPL.

${ }^{193}$ Vickers, Farmers and Fishermen, 153-167.
} 
Revolution, that same figure had fallen to $2 \% .{ }^{194}$ The declension in vessel ownership among workers underscores the general concentration of economic power in the hands of a relatively small percentage of the population that occurred throughout the colonies during the eighteenth century. ${ }^{195}$

Typically, vessels were not owned by a single individual. Salem merchant Timothy Orne is a case in point. He owned 5/8 of the schooner Sally, while Benjamin Osgood, who owned a flakeyard and dried fish for Orne, owned 2/8 and John Cloutman, the skipper, owned 1/8. Orne owned $1 / 2$ of the schooner Louisa, while John and David Felt, who also owned a flakeyard and dried fish for Orne, owned 3/8 and Thomas Stevens, the skipper, owned 1/8. Orne owned 1/2 of the schooner Esther and Benjamin Osgood owned the other 1/2 In fact, of all the vessels listed in his ship book for 1760, Orne only owned one vessel outright, the schooner Eunice. ${ }^{196}$ Ownership was divided among two or more investors in order to limit an individual's capital investment, and thereby reduce risk. Yet, despite this fact, overall vessel ownership and control over this means of production had constricted in the eighteenth century as economic power concentrated.

Flakeyards were also necessary for finishing the processing of raw fish into a product that could withstand long-distance transport. These productive means had developed in port towns as a result of the shift toward an offshore fishery. As mentioned above, they were large plots of land with different types of infrastructure. The cost of the land, along with the

${ }^{194}$ Vickers, Farmers and Fishermen, 161.

${ }^{195}$ For more on the concentration of economic power in Massachusetts, New York and Pennsylvania, see Nash, The Urban Crucible. For Virginia and Maryland, see Hornsby, British Atlantic, American Frontier, 100-104. For the West Indies, especially Jamaica, which became Britain's foremost sugar producing island in the eighteenth century, see Richard S. Dunn, Sugar and Slaves: The Rise of the Planter Class in the English West Indies, 1624$1713,2^{\text {nd }}$ ed., (New York: W.W. Norton \& Company, Inc., 1973). For wealth concentrations in Gloucester and Marblehead, Massachusetts, two of the largest commercial fishing ports in eighteenth century New England, see Heyrman, Commerce and Culture, 415, Table I.

${ }^{196}$ Timothy Orne Ship’s Ledgers, 1758-1768, JDPL. 
construction and maintenance of this infrastructure, effectively prohibited a majority of the working population from controlling any productive means. ${ }^{197}$

Some upward social mobility was possible in the commercial fishing industry given the right circumstances. There were those who worked as fishermen and were eventually able to purchase flakeyards or shares in vessels. Of the few fishermen who were able to reach the rank of skipper in the eighteenth century, roughly $17 \%$ then went on to purchase part of a vessel. ${ }^{198}$ Family status and the earning potential that accompanied the role of skipper helped men achieve some measure of control over their lives and fortunes. Benjamin Punchard, the son of a skipper, worked on board Salem merchant Timothy Orne’s schooners Molly and Esther as a cuttail and sharesman between 1753 and 1760 before he was able, possibly through an inheritance, to purchase a flakeyard. ${ }^{199}$ David and John Felt labored as sharesmen and skippers on Orne's schooners Molly and Eunice between 1753 and 1767 before they were able to purchase a flakeyard. ${ }^{200}$ These men were the exceptions to the rule, however. Most fishermen in the eighteenth century remained poor and productive means stayed beyond their meager purchasing power.

The capitalist nature of the eighteenth century commercial fishing industry most benefited those who owned the means of production. Vessel-owning merchants with their own flakeyards routinely earned a greater percentage from each fishing expedition than the workers

\footnotetext{
${ }^{197}$ Vickers writes that in the eighteenth century, cod fishermen "could expect to acquire some real estate, especially if the father and mother outlived their parents and came into an inheritance. But this did not commonly happen until they were in their forties, and even then they rarely succeeded to more than a little cottage or part of a house." Vickers, Farmers and Fishermen, 177.

${ }^{198}$ Vickers, Farmers and Fishermen, 161.

199 Timothy Orne Shipping Papers, Schooner Molly, Box 7, folder 10, 1751-57; and Schooner, Esther, Box 5, folder 2, 1759-61, JDPL; and Timothy Orne Account Book, 1762-1767, JDPL. Also, see Vickers, Farmers and Fishermen, 183.

${ }^{200}$ Timothy Orne Shipping Papers, Schooner Molly, Box 7, folder 10, 1751-57, JDPL. For evidence of their work on the schooner Eunice and their ownership of a flakeyard, see Timothy Orne Ledgers, 1762-1767, JDPL.
} 
themselves. They typically received $3 / 8$ of the net proceeds from each catch. The crew received 5/8, but this was divided among, on average, seven men. Thus, each fisherman usually received only $9 \%$ of the net profits after risking his life in dangerous working conditions on the offshore banks. A Boston political writer who used the alias "Montesquieu" underscored this fundamental fact of the cod fishing industry when he noted in 1763 "that those who carry it on get to themselves but a bare subsistence."201

Vessel owners were not guaranteed financial success, to be sure. They ran the risk of losing their capital investments in storms at sea. In addition, they were responsible for any and all repair costs following each and every voyage. Indeed, 2/8 of the vessel owner's profits from each catch were specifically allocated to cover the wear and tear on the vessel. Salem merchant Timothy Orne paid local sail maker Eleazar Moses $£ 33$ for the "making \& mending” of the Esther’s sails on April 15, 1763. On another occasion, August 12, 1765, Orne paid Moses $£ 30$ for "making a New Suit of Sails." One year later, the Salem merchant paid local carpenter Josiah Cabot $£ 3$ for work on his schooner. He also paid a Salem blockmaker named King $£ 2$ for materials; Samuel Lascombe, a Salem joiner, $£ 7$ for his "part of Joyner's work of the Schooner Esther;” and Jonathan Mansfield, a Salem iron worker, the sum of $£ 41$ for work on the schooner. ${ }^{202}$ There is no doubt that entrepreneurs ventured and risked much in the fishing industry.

Yet, there was a difference between the contributions of workers and merchants to the fishing industry. Maritime insurance could be purchased and vessel ownership could be divided in order to mitigate the risk involved with capital investment in the cod fisheries. Moreover, repairs could be made and new vessels could be built. Worker's lives, by contrast, could not be

\footnotetext{
${ }^{201}$ Boston Evening Post, November 28, 1763.

${ }^{202}$ Timothy Orne Shipping Papers, Schooner, Esther, Box 5, folder 3, 1760-68, JDPL.
} 
repaired or replaced. As the 1763 journalist astutely noted, those who experienced the greatest risk benefited the least in the production of the single most valuable export commodity in all of colonial New England.

\subsection{SHIPPING COD}

Once a catch had been dried, culled and weighed, and the value of the catch had been factored into a ledger, cod was then packed in hogsheads for overseas shipping. As with drying and culling, merchants could pay others for packing services or charge for these services. On several occasions, William Knight paid Archibald Selman for “packing” cod from Selman’s “fish house.” On August 16, 1773, he charged Knight £0.1.4 for packing 2 hogsheads of fish, or eight pence per hogshead. Knight paid Joseph Homan for packing cod from Homan's fish house into hogsheads in $1770 .{ }^{203}$ Isaac Smith, Esquire, sold Gloucester merchant Daniel Rogers 240.25 quintals in 1772, and he charged Rogers eight pence per hogshead for packing thirty-one hogsheads. In 1774, Rogers paid the Gorham brothers for “making” a fare and "packing” fish. ${ }^{204}$ Yet there were occasions when merchants charged for packing services. Captain Samuel Gale purchased primarily Jamaica grades of dried cod from Richard Pedrick between 1771-1775, and he paid Pedrick packing fees. Captain John Nut, Captain William LeCraw and Captain William Blackler did likewise. ${ }^{205}$

Carters then hauled the packed fish to the docks and loaded it onto waiting ships. Dixey Morgan of Salem carted 100 quintals of fish for Marblehead merchant Richard Stacey at some

\footnotetext{
${ }^{203}$ William Knight Account Book, 1767-1781, JDPL.

${ }^{204}$ Daniel Rogers Account Book, 1770-1790, JDPL.

${ }^{205}$ Richard Pedrick Account book, 1767-1784, MDHS.
} 
point in the late 1760s or early 1770s, and he deposited his earnings with Salem merchant Miles Ward. At the same time, Nathaniel Peas of Salem carted fish for local merchant John Field, then deposited his earnings just as Morgan had done. ${ }^{206}$

If vessel-owning merchants were short on ship space, then they could rely on others to transport their dried cod overseas. Marblehead merchant Richard Pedrick paid freight charges to Captain Samuel Gale between 1771 and 1775 for shipping Jamaica grade dried cod to the West Indies. ${ }^{207}$ Similarly, Marblehead merchant William Knight paid Thomas Gerry, Jr., owner of the schooner Fox, to ship merchantable grade dried cod to southern Europe and refuse grades to South Carolina from 1772 to $1774 .{ }^{208}$ Gloucester merchant Daniel Rogers paid Newbury ship captain Ebenezer Parsons freight charges for transporting 400 quintals of undesignated "fish" in 1786. ${ }^{209}$ Salem merchant Miles Ward utilized the talents of coasters Edward Smith and Samuel West, Jr. to freight various goods to Boston between 1765 and 1769. ${ }^{210}$ Dividing shipments of cod between their own vessels and those belonging to others also mitigated risks associated with transoceanic shipping.

Some merchants acted solely in the capacity of fish exporter, not bothering to venture capital in outfitting risky deep-sea fishing ventures that constantly wore and tore on men and vessel. Wealthy vessel-owning fish exporters such as Jeremiah Lee of Marblehead purchased large quantities of dried cod, between 100-600 quintals at a time, from local suppliers, which could include other merchants, independent fishing companies and individual fishermen. On April 28, 1771, Lee, who at this point was listed as “Colonel Jeremiah Lee, Esquire,” purchased

\footnotetext{
${ }^{206}$ Miles Ward Ledgers, 1765-1772, JDPL.

${ }^{207}$ Richard Pedrick Account book, 1767-1784, MDHS.

${ }^{208}$ William Knight Account Book, 1767-1781, JDPL.

${ }^{209}$ Daniel Rogers Account Book, 1770-1790, JDPL.

${ }^{210}$ Miles Ward Ledgers, 1765-1772, JDPL.
} 
544 quintals of merchantable grade dried cod from Beverly merchant Thomas Davis. Lee then compensated Davis for weighing services, and he even paid to have Davis hire men to cart the fish to his trade vessel. What is more, in a currency-starved economy Lee paid for all of these things in cash that amounted to over $£ 434$. This was a single payment made immediately on the day of sale. Less impressive, Beverly exporter John Cabot purchased 216.5 quintals of merchantable fish from Davis on July 12, 1771. Like Lee, Cabot paid Davis for weighing services, and he paid in cash. Unlike Lee, Cabot paid Davis the $£ 173$ he owed later in August that year. Marblehead exporter Jacob Fowles bought between 120 and 267 quintals of merchantable grade dried cod from Davis from 1771-1773. ${ }^{211}$ Fowles paid in cash for the fish and weighing services. Michael Coombs, another Marblehead exporter, purchased 400 quintals of merchantable grade dried cod from Gloucester merchant Daniel Rogers in August, 1772. Like the other wealthy exporters, Coombs was able to pay cash in the sum of $£ 360 .^{212}$ The largest shippers sent loads amounting to more than 2,000 quintals overseas. ${ }^{213}$ Such New England fish specialists could, at times, even import fish from Newfoundland for re-export in order to fill an overseas order. ${ }^{214}$

Other merchants who wore various hats and acted as outfitter, shoreman, and exporter only had to buy fish from other providers during a poor season. Men such as William Knight of

${ }^{211}$ Thomas Davis Account Book, 1771-78, JDPL.

${ }^{212}$ Daniel Rogers Account Book, 1770-1790, JDPL.

${ }^{213}$ See, Massachusetts Shipping Records, 1686-1765, Part III, pp. 916-1143, Box 3, MHS. For example, on July 16, 1763, Marblehead fish exporter Robert Hooper sent 2,200 quintals on board the brig Pitt Packet, 100 tons, 8 men, Thomas Duxey, Master, bound for Bilbao, Spain. Later that year, on October 28, Marblehead fish exporter Jeremiah Lee sent 2,300 quintals on board the ship Gardoqui, 110 tons, 9 men, Nicholas Garden, Master, bound for Bilbao.

${ }^{214}$ In 1769, Massachusetts merchants imported 34,179 quintals of dried cod, most probably from Newfoundland and Nova Scotia, for the purposes of re-export. At the same time, Rhode Island merchants imported 12,930 quintals for re-esport, and Connecticut imported 4,334.5 quintals. "An Account of the Goods \& Produce Imported Into \& Exported from the several Ports on the Continent of North America, the Islands of Newfoundland, Bahamas, \& Bermuda, Coastways, between the $5^{\text {th }}$ of January $1769 \&$ the $5^{\text {th }}$ of January 1770," British North American Customs Papers, 1765-1774, MHS. 
Marblehead and Richard Derby of Salem owned their own vessels, which they used for fishing and trade, and their own flakeyards. These men successfully integrated the various components of the commercial fishing industry. They could mine the seas, dry the catches, and ship the end product overseas themselves.

Different types of dried cod traveled to different destinations around the Atlantic. Merchantable grades of fish were typically shipped to Iberian and Mediterranean ports in April and November to be exchanged for fish, wine, salt, and fruit. ${ }^{215}$ Refuse grades of fish were shipped in the winter months to fuel slave laborers on plantations in the Southern and West Indian colonies. The southern colonies traded pork, tobacco, and naval stores, while the West Indian colonies exchanged sugar, molasses, and rum. By the eighteenth century, the spring and

fall shipments to Iberian and Mediterranean ports represented a minority of the fish trade. ${ }^{216}$ Work patterns adjusted accordingly, and most shipments were made during the winter months to the slave plantations. Merchants could then use trade goods received in exchange in their shops to sell to fishermen and other locals. With the profits, they could purchase manufactured goods from Europe. If a merchant acted in the capacity of outfitter, shoreman, exporter and shop owner, he turned profits at every stage of the fishing industry.

\subsection{EXPLOITATION}

For their part, workers in the cod fisheries experienced varying degrees of exploitation. It has already been established here that no worker in the industry profited from his labors as much as

${ }^{215}$ Vickers, Farmers and Fishermen, 104.
${ }^{216}$ See chapter three. 
the merchants. Indeed, most laborers remained in debt to these merchants. ${ }^{217}$ Having said this, it was generally the case that free laborers were less exploited than their un-free counterparts. Within the free labor group, skippers were the least exploited. They generally earned more on an annual basis than other workers and a greater percentage were able to gain partial control over some of the means of production in the industry, as we shall see below. Sharesmen were more exploited, earning less and having almost no financial wherewithal to control even the slightest part of any productive means.

Of all the free laborers in the commercial fisheries, cuttails were the most exploited workers. The meager earnings of these child laborers were deposited in someone else's account, one that usually belonged to a parent or an older sibling. After applying to Governor Thomas Hutchinson in 1770 for relief following the deep sea deaths of 170 "Men and Boys," Marblehead fish merchants observed "many Parents" in town were "deprived of the Earnings of their Sons, which was their chief Support.”218 Such parents typically purchased goods from nearby merchants against these earnings. Take, for example, the Salter family in Marblehead. Elizabeth Salter may have been a widow through most of the 1760s and early 1770s as she maintained her own account with merchant William Knight. Given the patriarchy of the time and place, Elizabeth needed a man, Francis Felton, to witness her financial dealings with Knight. Her sons, Thomas and Benjamin Salter, worked as cuttails on board Knight's schooners Molly and Barnett. Elizabeth routinely deposited her two sons' earnings in her own account and purchased provisions for the family, along with silk handkerchiefs, fabrics, and spending cash for herself,

\footnotetext{
${ }^{217}$ Vickers, Farmers and Fishermen, 153-167.

${ }^{218}$ By the Honorable Thomas Hutchinson... (Boston: Richard Draper, 1770), Early American Imprints, Series I: Evans \#42125.
} 
against the product of Thomas and Benjamin’s labors. ${ }^{219}$ Widow Mary Foster deposited her son Jonathan's earnings in her account with Beverly merchant Thomas Davis in $1771 .{ }^{220}$ Lucy Yonger likewise deposited her sons Levy and Willard's earnings in her account with Gloucester merchant John Stevens between 1771-75. ${ }^{221}$ The widow Mary Glover had her own account with Salem merchant Timothy Orne from 1762 to 1766 . She bought goods against the earnings of her son Samuel. ${ }^{222}$ Benjamin Webber had an account with Gloucester merchant Daniel Rogers. His son, Benjamin, Jr., worked on various schooners for Rogers between 1770-74. The father deposited the son's earnings and bought goods against those earnings until 1773, when Benjamin, Jr. became twenty-one and was old enough to open his own account with the merchant. Fortunately for Benjamin, Sr., his younger son, Joseph, came of age about this time and provided purchasing power for the father. ${ }^{223}$ In short, younger workers in the fishing industry typically earned less than their adult counterparts and did not have control over their earnings. ${ }^{224}$

Unfree laborers similarly lacked control over their earnings, but they had even less power over their lives. Servant labor was not as large a component of the New England commercial cod fisheries as it was in Newfoundland in the eighteenth century. ${ }^{225}$ On the eve of the American Revolution, however, there were still men who bound themselves to another human being for a specified amount of time. Little is known about why these men did this and what they gained from the experience. Most likely they were working off debts. It is clear that

\footnotetext{
${ }^{219}$ William Knight Account Book, 1767-1781, JDPL.

${ }^{220}$ Thomas Davis Account Book, 1771-78, JDPL.

${ }^{221}$ John Stevens Account Book, 1769-75, JDPL.

${ }^{222}$ Timothy Orne Ledgers, 1762-1767, JDPL.

${ }^{223}$ Daniel Rogers Account Book, 1770-1790, JDPL

${ }^{224}$ For more on the connections between maritime labor and age exploitation in early America, see Vickers, Young Men and the Sea, esp. 129.

${ }^{225}$ For servant labor in Newfoundland during the eighteenth century, see Head, Eighteenth Century Newfoundland; and Handcock, Soe longe as there comes noe women.
} 
during this period of servitude workers' earnings were deposited in their master's accounts. Between 1770-72, two servants belonging to Captain Edward Hales worked on schooners belonging to Richard and Thomas Pedrick of Marblehead. Hales' account was credited for their labors. ${ }^{226}$ Other sea captains maintained servants and exploited their labor capacity in the fishing industry. Captains John Reed, David Ross and John Lewis each had a servant employed with Richard Pedrick on fishing schooners in the early 1770s, and each received the earnings of these men. ${ }^{227}$ At the same time, Captain Nicholas Thorndike had a servant employed on one of Beverly merchant Thomas Davis' schooners. ${ }^{228}$ Most of these servants worked as cuttails, and were probably young men who could not choose their employers or the type of work that they performed. In rare instances, fishermen had servants of their own. Robert Fry went on three fares for Salem merchant Richard Derby in 1756. Fry's servant worked shoulder-to-shoulder with him on the schooner Three Sisters. Fry then deposited his own earnings, and those of his servant, into his own account. After the fishing fares, Fry put his servant on a trade voyage for Derby and collected earnings from that work as well. ${ }^{229}$ The exploited could thus exploit others in a system that rewarded such behavior.

Slave labor was never an integral part of the New England cod fishing industry, largely because the region did not maintain a large slave population. Yet by the 1760 s and early 1770 s, a few Massachusetts slaves contributed to the daily operations of this enterprise. David Montgomery's slave “Cato” worked on Beverly merchant Thomas Davis’ schooner Swan in the

${ }^{226}$ Richard Pedrick Account Book, 1767-1784, MDHS; and Thomas Pedrick Account Book, 1760-1790, MDHS.

${ }^{227}$ Richard Pedrick Account Book, 1767-1784, MDHS.

${ }^{228}$ Thomas Davis Account Book, 1771-78, JDPL.

${ }^{229}$ Richard Derby Ledger, 1757-1776, JDPL. 
early 1770s. ${ }^{230}$ In nearby Salem during the mid-1760s, Peter Frye forced "his Negro" to carry salt for local fish merchant Richard Derby, undoubtedly for use in curing fish taken on Derby's schooners. Frye charged Derby two shillings ten pence for the day's labor, almost exactly what white day laborers earned in the area. ${ }^{231}$ In 1768 Captain Thomas Peach rented "his Negro Charles" to Marblehead merchant William Knight. Charles "Carried [wheel]Barrows" for Knight in May and November, most likely transporting spring and summer fare cod to and from the merchant's flakeyard. ${ }^{232}$ Similarly, Marblehead merchant Richard Pedrick rented his "Negro" to Joshua Orne "for house" work one day in December, 1776, just after Thomas Jefferson declared that all men had the right to liberty. ${ }^{233}$ These men were surely the most exploited laborers in the commercial fishing industry. Slaves would have endured the loss of their liberty in addition to their earnings, and they would have experienced any racial antipathy that existed in an industry that was mostly white. Regardless of their race or age, however, most of the workers in the cod fisheries experienced some degree of exploitation.

\subsection{MULTI-FUNCTIONAL OCCUPATIONAL IDENTITY}

Through their struggle to earn a living and feed their families, workers in the commercial fishing industry became jacks-of-all-trades. ${ }^{234}$ In addition to fishing on the Grand Bank, Burnham and

${ }^{230}$ Thomas Davis Account Book, 1771-78, JDPL.

${ }^{231}$ Richard Derby Ledger, 1757-1776, JDPL.

${ }^{232}$ William Knight Account Book, 1767-1781, JDPL.

${ }^{233}$ Richard Pedrick Account Book, 1767-1784, MDHS. There were four references to free persons of color in Daniel Rogers Account Book, 1770-1790, JDPL. Two of these men were sailors and the others were day laborers. They each had their own accounts with Rogers.

${ }^{234}$ Pope maintains that most workers in the seventeenth-century English migratory fishing industry were not full-time fishermen. "The fisheries were an opportunity for dual employment no less than other rural industries like the production of cloth or the mining of tin,” he writes. Pope, Fish Into Wine, 169. For his part, Vickers believes 
his crew took on merchant mariner positions for the Choats at the tail end of 1774, when cold December winds and waters made working the North Atlantic more perilous and less productive. The same vessel that had taken them from Ipswich to the Grand Bank fishing would now take them south on a trading voyage to warmer climes and slave plantations in Virginia. The schooner Polly's articles list Burnham, formerly the skipper of the same vessel, as master. John Andrews signed-on as mate, while Stephen Low, Joseph Burnham and Daniel Andrews shipped as seamen. Aside from the fact that George Pierce and Thomas Yates did not sign the ship’s articles for this voyage, the entire crew had previously gone deep-sea fishing. Each man was entered on December 15, 1774. There were three witnesses to “each Man’s Signing” the ship’s articles. Their monthly wages were as follows: Joshua Burnham earned £2.8.0; John Andrews earned £1.12.0; and the others each earned $£ 1.6 .8 .^{235}$ In this manner, the same vessel and roughly the same men continued working and earning for the same employer, and all of their labor activities helped prosecute the commercial cod fishing industry. The Polly and her crew were not exceptional in this regard.

Eighteenth-century schooners typically served this dual purpose of fishing and trading. ${ }^{236}$ In Ipswich, the Polly itself was taken out on six fishing fares from 1772 to 1774. Over the same period, the schooner re-exported West Indian trade goods and freighted refuse

"by-employment” was primarily associated with farming in eighteenth century Massachusetts. Vickers, Farmers and Fishermen, 247-258.

235 Joshua Burnham Papers, 1758-1817, Schooner Polly, 1771-1776, Box 1, Folder 4, JDPL. An invoice for the schooner lists the outbound cargo as molasses, rum (most likely locally produced, "New England” rum), West India rum, sugar, cod, pollock, mackerel, train oil, pickled fish, “clove water” and salt. Beans and wheat were purchased in various Virginian ports and brought back to Massachusetts.

${ }^{236}$ According to Pope, seventeenth century English fishing vessels involved in the migratory fishery at Newfoundland also typically served this dual purpose of fishing and trading. He writes "the vessels themselves were largely interchangeable.” Pope, Fish Into Wine, 104. Barry Cunliffe has similarly noted the propensity of medieval Northern Europeans in using their fishing vessels to transport goods to overseas markets "in slack periods.” Barry Cunliffe, Facing the Ocean: The Atlantic and its Peoples, 8000BC-AD1500 (Oxford: Oxford University Press, 2001), 542. 
grades of dried cod to various ports in Virginia, Maryland, and the Carolinas. ${ }^{237}$ In December 1761 the schooner Abigail was used to transport dried cod and other cargo from Ipswich to Virginia and Maryland. The following September she headed out on a fall fare to unspecified “Banks.”238 Between 1768 and 1770 the schooner Neptune went out on at least five fishing fares in the spring, summer and fall seasons. During the winter months, the same vessel left Ipswich and took dried cod to Dominica in the West Indies, and various ports in Virginia and Maryland. $^{239}$

In Gloucester, between 1762 and the beginning of 1764, the schooner Endeavor went on at least four fishing fares. Then, at the end of 1762 and 1763, the same vessel transported goods to ports in Virginia and Maryland. ${ }^{240}$ The schooner Hannah, belonging to Daniel Rogers, worked on fifteen fares from 1770 to 1774 . Every winter during this period, she traveled to Virginia on trade missions. Rogers’ schooner George went on sixteen fares between 1770 and 1775. In December, 1771, she was used on a trade mission to Virginia. The following winter, she transported trade goods to South Carolina. The schooner Lucky went on a least five fares from 1770 to 1772 . At the end of 1772 , she was used to transport trade goods to North Carolina. The schooner Liberty went on twelve fishing fares between 1770-73. During the winter months of 1772 and 1773, she was used on trade missions to South Carolina and then the West Indies. The schooners Rachel, Fame and Two Brothers served similar duties during the early 1770 s. $^{241}$ In Beverly, schooners belonging to Thomas Davis were utilized in this dual capacity. Between 1771-73, the schooner Volant was taken out on nine fishing fares and three trade

\footnotetext{
237 Joshua Burnham Papers, 1758-1817, Schooner Polly, 1771-1776, Box 1, Folder 4, JDPL. Merchant’s sailing orders rarely specified ports in the Southern colonies. Captains were simply to go to a region and sell the cargo to the best advantage.

${ }^{238}$ Joshua Burnham Papers, 1758-1817, Schooner Abigail, [c.1762], Box 1, Folder 1, JDPL.

239 Joshua Burnham Papers, 1758-1817, Schooner Neptune, [1766-1770], Box 1, Folder 3, JDPL.

240 Joshua Burnham Papers, 1758-1817, Schooner Dolphin, [c.1762-64], Box 1, Folder 1, JDPL.

${ }^{241}$ Daniel Rogers Account Book, 1770-1790, JDPL.
} 
voyages to Virginia each December. The schooner Swallow did the same. The Swan was taken on six fares between 1771-72, and made at least one trade voyage to Virginia at the end of $1771 .^{242}$

In Salem, Timothy Orne's schooner Esther left in December, 1759 for a trade voyage to South Carolina and back. For the next two Decembers, the same schooner was taken to Maryland on similar voyages. In the winter of 1762, she was taken back to South Carolina. The Esther was also taken on at least eight fares between 1760-63. ${ }^{243}$ Orne's schooner Molly did double-duty over an extended period. She worked twenty-five fares between 1752-56, six fares between 1758-59, and she was taken on a fall fare to the Grand Bank in 1767. From 1753-58 she made trade voyages to North Carolina and Maryland. Then, in 1760 and 1761, she was taken to Monte Christo in the West Indies. ${ }^{244}$ Richard Derby’s schooner Three Sisters went on four fishing fares in 1756 before departing on a trade voyage to South Carolina in the winter. At the same time, Derby’s schooner Three Brothers went on three fares before traveling to Virginia. ${ }^{245}$ In nearby Marblehead, Richard Pedrick's schooner Molly left in the winter of 1768-69 with a load of refuse grade dried cod bound for Barbados. The vessel also went on at least eleven fishing fares between 1766 and $1771 .^{246}$

Like the schooners, many men who went on fishing fares in the spring, summer and fall went on trade voyages during the winter months each year. Joshua Burnham went as skipper/master of various Gloucester and Ipswich schooners to off shore banks and then to ports

\footnotetext{
242 Thomas Davis Account Book, 1771-78, JDPL.

243 Timothy Orne Shipping Papers: schooner Esther, 1759-61, Box 5, folder 2; and schooner Esther, 1760-68, Box 5, folder 3, JDPL.

244 Timothy Orne Shipping Papers: schooner Molly, 1751-57, Box 7, Folder 9; schooner Molly, 1751-57, Box 7, Folder 10; schooner Molly, 1758-60, Box 7, Folder 11; and schooner Molly, 1761-66, Box 7, File 12, JDPL.

245 Richard Derby Ledger, 1757-1776, JDPL.

${ }^{246}$ Richard Pedrick Account book, 1767-1784, MDHS; and Richard Pedrick Papers, schooner Molly, [c.176671], Box 2, Folder 28, MDHS.
} 
in the Southern and West Indian colonies throughout the 1760 s and early 1770 s. For a period of nine years between 1766-1774, John Andrews worked as sharesman/mate alongside Burnham on these expeditions/voyages. ${ }^{247}$

In Gloucester, the crews of schooners belonging to Daniel Rogers worked in this dual capacity as fishermen and merchant mariners. Elisha Bray worked on board the Rachel for three fares in 1770 before laboring on the Hannah transporting trade goods to Virginia in December. Alford Davis worked on board the Robinhood for three fares in 1770 and the Liberty for just as many fares one year later. At the end of 1771, he worked on the Hannah on a trade mission to Virginia. Benjamin Webber, Jr., worked on three fares a year from 1770 to 1774 on board the Robinhood, Liberty, George and Hannah. Each winter he helped transport trade goods to Virginia on the Hannah. 248

In Beverly, John Lovett skippered the schooner Volant for merchant Thomas Davis between 1771-73. Over the same period, he also worked as master on the same vessel on trade voyages to Virginia. Joseph Thorndeck was one of Lovett's crewmen for these journeys in 1771. Joseph Lovett skippered the schooner Swallow for Davis at the same time, and to the same places, his brother commanded the Volant. Thomas Simonds worked as a crewmember on the fishing fares and the trade voyage on the Swallow in 1771. Jonathan Harry and William Ober worked on board the schooner Swan for Davis on fishing fares and a trade voyage to Virginia in $1771 .^{249}$

In Salem, Benjamin Henderson worked as mate on board Timothy Orne’s schooner Esther, Tobias Davis, Jr., master on a trade mission to South Carolina at the end of 1759.

\footnotetext{
247 Joshua Burnham Papers, 1758-1817, JDPL.

248 Daniel Rogers Account Book, 1770-1790, JDPL.

249 Thomas Davis Account Book, 1771-78, JDPL.
} 
Having been promoted, Henderson went as master to Maryland the following two Decembers. He also went on at least eighteen fares as the Esther's skipper between 1760-64. He and Benjamin Punchard, who went as mate, were the only two of the five-man crew on board the Esther on its voyage to Maryland at the end of 1760 that had gone fishing throughout that year. However, the following December the entire five-man crew, including Benjamin Henderson, master; Benjamin Punchard, mate; Samuel Whitford, Jr., mariner; George Cook, mariner; and James Bickford, mariner, had all been on fishing prior fares on the Esther. ${ }^{250}$ William Cumins was one of the crewmembers on board Richard Derby's schooner Three Sisters for its four fares in 1756. He then went on the winter trade mission to South Carolina. At this time, Richard Masury worked on Derby's schooner Three Brothers for its three fares. He then went on the winter trade mission to Virginia. ${ }^{251}$

In Marblehead, Jonas Dinnis worked as a skipper for merchant Thomas Pedrick for at least three fishing fares from 1761 to 1762 . In 1761, Dinnis also worked as a mariner on Pedrick’s schooner Salisbury, Thomas Dixey, master, on a trade voyage to Cadiz, Spain. Joseph Pribble also signed on as a mariner on this transatlantic trip in 1761, after he had worked as a sharesman for Pedrick on a fare earlier that year. William Pedrick worked as a ship's boy on this trade mission, after he worked as a cuttail on a fishing fare for Thomas Pedrick. Nicholas Girdler, Jr., also worked for Pedrick in a dual capacity. Girdler went as a sharesmen on four fares between 1774 and 1775 before he signed on Pedrick’s schooner Content, Andrew Martin, master, in $1775 .{ }^{252}$ John Chin Knight, who worked his way up from cuttail to sharesman to

\footnotetext{
${ }^{250}$ Timothy Orne Shipping Papers, schooner Esther, 1759-61, Box 5, Folder 2.

${ }^{251}$ Richard Derby Ledger, 1757-1776, JDPL.

252 Thomas Pedrick Account Book, 1760-1790, MDHS.
} 
skipper between 1768-1775, was also master of William Knight’s schooner Fox in $1778 .^{253}$ All of these maritime laborers earned wages for their work on trade missions in addition to their pay for the fishing fares.

Moreover, workers in the commercial fishing industry supplemented their wages on these trade voyages. The foremost means by which they could pad their earnings involved certain trade "privileges." In a typical voyage from Massachusetts to the Southern slave plantations, Burnham mastered the schooner Neptune on a voyage to Virginia and Maryland in the winter of 1768-69. Most of the crew was "shipped" on November 22. The final seaman was added on December 5. Their wages per month were as follows: the master earned $£ 2.8 .0$; the mate £1.12.0; and each seamen earned £1.6.8. Their "time on board" was listed as 4 months and 12 days for everyone except the delinquent seaman, who was on board for 3 months and 20 days. The crew’s “wages due,” which included deductions for the Greenwich Hospital tax and any advance wages, were as follows: the master earned £8.3.3; the mate earned $£ 4.16 .5$; the three seamen who shipped on November 22 earned £3.19.4 each; and the final seamen earned £3.8.8. However, the Choats also allowed Burnham “100 bushels” of space in the schooner's hold to transport his own trade goods. The mate was permitted "50 bushels," and each of the four seamen were allowed "35 bushels." 254 Unfortunately, there is no record of what type of trade good the men used, or how much they earned in trade from their items. But, it is safe to assume

${ }^{253}$ William Knight Account Book, 1767-1781, JDPL.

${ }^{254}$ Joshua Burnham Papers, 1758-1817, schooner Neptune, [c.1768-70], Box 1, Folder 3, JDPL. Also, see Joshua Burnham Papers, 1758-1817: schooner Abigail, [c.1761-62], Box 1, Folder 1; schooner Dolphin, [c.1764], Box 1, Folder 1; schooner Endeavor, [c.1762-64], Box 1, Folder 1, JDPL; and Timothy Orne Shipping Papers, schooner Molly, 1758-60, Box 7, Folder 11, JDPL. Since 1729 Parliament had required American colonists, particularly those involved in maritime commercial activities, to pay sixpence every month, giving rise to its pseudonym, the "Sixpence Duty." The profits from the duty were meant to support a seaman's hospital located in Greenwich, England. For more on the Greenwich Hospital tax, see Allyn B. Forbes, "Greenwich Hospital Money," New England Quarterly, Vol. 3, No. 3 (July, 1930), 519-526. The hospital was closed in 1869 and re-opened in 1873 as the Royal Naval College. Today, the facility operates as the Maritime Museum. 
that Burnham, as master, made more money than the rest of the crew as a result of having greater space in the hold for trade goods. ${ }^{255}$

If maritime laborers needed ready money in a hurry, they could negotiate for an advance on their wages for the trade mission. The crew of the Polly in 1774 were each given one month's advance wages amounting to $£ 2.8 .0$ for the master; $£ 1.12 .0$ for the mate; and $£ 1.6 .8$ for each of the three seamen. ${ }^{256}$ Burnham, his mate and three seamen all received similar advance wages for a voyage from Ipswich to Dominica in the West Indies in December, $1766 .{ }^{257}$ Through such $^{2}$ advance wages, monthly wages and trading privileges, workers in the commercial fishing industry could extend their seasonal earnings from fishing fares.

Skippers also acted as agents, or supercargoes, for their vessel-owning merchants on trade voyages. On December 13, 1760, Salem merchant Timothy Orne ordered Benjamin Henderson, skipper and master of the schooner Esther, to travel to Maryland and "find the Sloop Dolphin, Jonathan Gardner, Jr., Master.” Once he found the sloop, Henderson was to "afford her all the Assistance in your power that she wants \& put aboard her the Two Men that I send to her.” If the Dolphin "would Require another hand,” then Henderson was to "put aboard your own Mate, Mr. Punchard.” Henderson was further ordered to sell the cargo on board and buy wheat, corn, pork, beans, skins, or "Bar Iron," and to "leave no Outstanding Debts in the Country,” and "Neither suffer any Tobacco to be brought home.”258

\footnotetext{
${ }^{255}$ Workers on trade voyages had enjoyed this "privilege” from at least the twelfth century, and in Ralph Davis' words it became a "customary right" in the English shipping industry by the eighteenth century. See, Rediker, Between the Devil and the Deep Blue Sea, 130-131; and Ralph Davis, The Rise of the English Shipping Industry In the $17^{\text {th }}$ and $18^{\text {th }}$ Centuries (London: Macmillan \& Company Limited, 1962), 147.

${ }^{256}$ Joshua Burnham Papers, 1758-1817, schooner Polly, 1771-1776, Box 1, Folder 4, JDPL.

257 Joshua Burnham Papers, 1758-1817, schooner Neptune, [c.1768-70], Box 1, Folder 3, JDPL. Also, see Thomas Davis Account Book, 1771-78, JDPL.

${ }^{258}$ Timothy Orne Shipping Papers, schooner Esther, 1759-61, Box 5, Folder 2. At this point, it was illegal for Massachusetts merchants to directly import tobacco from the Southern colonies. Violators were subject to the confiscation of their vessel and trade goods. For evidence of this fact from a later date, see Orne's orders to George
} 
In addition, Joshua Burnham took the schooner Dolphin to Virginia and Maryland in December, 1764. Before he left, Gloucester merchant Ezekiel Woodward, Jr., in typical fashion, issued specific orders to his trusted man. Woodward's orders were as follows: “As to Selling your Cargo, you must, in order to Make all Possible Dispatch, Sell the Bigger Part of it by Whole Sale - Unless you Sell of[f] Very fast Indeed by Retail. Towards the Last of your Cargo you had Better Sell some of your things for Something Less than the first cost than to Bring them Home again - if you're not Like to get a full Load. Don’t Stay to Retail out your Cargo so as to make it Late home Because of Spoiling the fishing Voyage. Make as much possible Dispatch Back again to Gloucester.” Speed, again, mattered in the commercial fishing industry in an age without refrigerated holds. Not only was there the danger that the dried cod would spoil as it sat in the ship’s hold traveling around warm water ports waiting to be sold, but there was also the risk that the fishing vessel, its skipper and the crew would not return in time to catch the first fish of the year, which was the most valuable. In closing, the Woodward wrote: "Brake No acts of Trade. Leave no Debts Behind you in the Country.”259

In short, skippers/masters had more responsibilities than other mariners. They were entrusted with their merchant employer's reputation, along with his vessel and commodities, on trade missions. On fishing expeditions, the same skippers/masters were responsible for recruiting a company, choosing a location to fish, navigating and keeping count of the fish taken. These men wore many hats, and the overall success of the industry depended in no small part on

Chapman, dated December 9, 1771, Timothy Orne Shipping Papers, schooner Molly, 1771-72, Box 7, Folder 13. Here, Chapman is explicitly told: "Be very careful that you break no Acts of Trade, neither must you Suffer any Tobacco or any other Goods to be brought home in our Schooner that will in the least Expose her to a Seizure.”

259 Joshua Burnham Papers, 1758-1817, Schooner Dolphin, [c.1762-64], Box 1, Folder 1, JDPL. On November 20, 1753, Salem merchant Timothy Orne ordered John Felt, skipper and master of the schooner Molly, "to get Ready to Come away by the Last of January if Possible that so you may be at home timely for The Spring Sable [Island Bank] Fair which is of more Consequence than the Maryland Voyage.” Timothy Orne Shipping Papers, Schooner Molly, 1751-57, Box 7, Folder 10. 
their endeavors. These responsibilities explain why skippers/masters earned more in annual wages than sharesmen/mariners in annual wages, including earnings from trade voyages and fishing fares. The earnings of the entire crew came with certain risks while trading in the warmer southern climes, however.

In addition to shipwreck, drowning, and other work-related accidents, workers in eighteenth century Massachusetts’ merchant marine ran the risk of contracting diseases while on trade missions to tropical ports in the West Indies. One recent study estimates that while 39\% of the deaths of merchant mariners can be attributed to work-related accidents, $54 \%$ of those deaths were caused by malaria and yellow fever contracted in the West Indies. As a result, 30\% of colonists who went on trade voyages never reached the age of thirty. ${ }^{260}$ As will be shown in the second chapter, West Indian slave plantations represented the principal overseas markets for dried cod in the eighteenth century. The skipper of the Polly, who died from a fever contracted in the West Indies, was therefore representative of an important pattern.

Workers on trade voyages also ran the risk of corporal punishment. ${ }^{261}$ Captains of vessels on trade missions were legally allowed to beat their crewmembers. Even though legal authority might be restrained by custom and ship-borne camaraderie, it was a reality faced by some and a constant threat to all. ${ }^{262}$ Ashley Bowen, who worked on off-shore cod fishing fares and traveled to the West Indies on trade missions for Marblehead merchants, underscored the tangible effects of this threat. After traveling to the West Indies the previous winter, Bowen was engaged on the same vessel as a young ship’s boy for a transatlantic trip to Spain in 1743 . His

\footnotetext{
${ }^{260}$ Vickers, Young Men and the Sea, 109-111.

${ }^{261}$ According to Vickers, skippers "lacked the legal authority" to beat their fishing crews. Vickers, Farmers and Fishermen, 151-152, esp. footnote \#12. More recently, Vickers has argued that even the forms of labor discipline merchant ship captains employed from the seventeenth century to the beginning of the nineteenth were not outside the bounds of the familiar and the acceptable. Such sea-borne discipline and authority, he maintains, "would have seemed entirely normal” to Yankee seafarers. Vickers, Young Men and the Sea, 215.

${ }^{262}$ For more on these restraints, see Vickers, Young Men and the Sea, 214-247.
} 
captain, Peter Hall, had the boy “pickled” for accidentally dropping dinner fowl overboard.

Bowen wrote of this experience:

My master stepped down to me and took me by the hand and said now you should not run away from him and brings me up on deck and orders the Boatswain to get two seizings of spun yarn, and I was tied to the rail by each wrist and my trousers let [down] about my heels and my frock tucked into my collar. The Cook was ordered to get a bowl of pickle from the beef cask; my feet [were] tied to the fife rail and master would take his cat with 9 parts of log line and give me a dozen strokes on my back; then take his hand full of pickle and pat it on my back; then take his quadrant and look for the sun; then took a tiff of toddy, and so regularly he would do that office, one after another. ${ }^{263}$

Eventually, one of the mates felt compelled to stay the captain's hand by threatening to testify against Hall in an admiralty court. Other workers on eighteenth-century trade missions were not so lucky, and no one halted the punishment. ${ }^{264}$ The merchant vessel could be a brutal work environment. Still, not getting a berth at sea and being forced to work at day labor could be a worse fate.

Fishermen who could not gain berths on trade voyages to warmer climes did day labor for wages in the cold winter months. Edward Woodbury worked as a cuttail for Beverly merchant Thomas Davis in the early 1770s. As a younger worker, he may have been denied a winter berth because of his youth. In December, 1772, he was doing day labor for Davis at the rate of two shillings eight pence per day. Other factors may have kept workers from seeking berths. John Lovett was a skipper for Davis around the time Woodbury was working as a cuttail and day laborer for the Beverly merchant. Lovett had a younger son, John, Jr., who also worked on fishing fares, and he may not have wanted to leave his family for three to four months on a trade voyage. At the end of 1772, he and his son were doing day labor for Davis at the same rate

\footnotetext{
${ }^{263}$ Smith, ed., The Journals of Ashley Bowen (1728-1813), Vol.1, 16.

${ }^{264}$ Rediker, Between the Devil and the Deep Blue Sea, 92-93, 212-222.
} 
given to Woodbury. Similarly, Benjamin Beckford, who worked as an independent off-shore fisherman, did day labor along with his two sons, Benjamin, Jr., and John, for Davis in January, $1774 .^{265}$

At the typical pay rate of two shillings eight pence per day, assuming they worked every day for thirty days, day laborers would have earned $£ 4$ per month in the early 1770 s. This would have been more money than any crewmember on trade voyages at that time would have seen, including the vessel's master himself. However, unlike work on a trade voyage in which laborers could expect several months pay, day labor was never guaranteed and rarely lasted for extended periods. Merchants typically hired day laborers for short-term projects, such as cleaning vessels, carting goods from one place to another and carrying fire wood. ${ }^{266}$ During the frigid winter months in Newfoundland, carrying fire wood became second nature for fishermen, and may have represented something like regular employment. ${ }^{267}$ Nevertheless, the work was usually physically demanding and hardly represented a promising career. If employers had no additional projects for the laborer once the initial job was done, then another employer with work would have to be found. Day labor was thus unreliable and hard.

Despite these drawbacks, day labor represented another means by which workers in the cod fisheries could extend their annual incomes and feed their families. During the second half of the eighteenth century, the increasingly exploitative nature of the industry motivated workers to develop a multi-functional occupational identity in order to increase their earning potential. Jacks-of-all-trades were commonplace in the commercial fisheries at this time.

\footnotetext{
265 Thomas Davis Account Book, 1771-78, JDPL.

266 These types of day labor can be found in the sources listed above in footnotes 34-43.

${ }^{267}$ Head, Eighteenth Century Newfoundland, 142.
} 
This occupational diversity has several implications. It has been asserted that cod fishermen's earnings "would cease” at the end of fishing seasons. ${ }^{268}$ Yet this conclusion is accurate only if we limit our definition of a worker in the fishing industry to a deep-sea handliner of cod. In truth, worker's annual earnings did not stop at the end of fishing seasons. Their employers in the fishing industry paid them for fishing fares, day labor, and trade voyages, all of which helped prosecute the Atlantic trade in dried cod. Moreover, workers could supplement their wages on trade voyages with private trade privileges. These were the same workers, working for the same employers in the same industry.

It is also clear that the labor hierarchy on board trade voyages and fishing expeditions were not polar opposites. The foremost authority on the colonial fishing industry has emphasized the egalitarian nature of ship life on fishing vessels. "The discipline that governed this more demanding workplace was essentially collective....the skipper was merely the first among equals," we are told. ${ }^{269}$ Yet, ship life in the fishing industry was not democratic. The sliding wage scale on board the Polly during its trade voyage in 1774 clearly delineated a labor hierarchy. Such stratification also existed on the same schooner during fishing expeditions in the form of the aforementioned divisions between the skipper and the rest of the crew and between the sharesmen and the cuttails. It is true that Burnham and his crew operated on a count system prior to their trade voyage to Virginia in 1774 and that such a system did obscure divisions between the men. However, whether they were fishing or trading, Burnham controlled the schooner and maintained his authority as head of the company of men. The divisions between skipper and crew, and between sharesmen and cuttails, were further exacerbated every time the men went on the share system.

\footnotetext{
${ }^{268}$ Vickers, Farmers and Fishermen, 123.

${ }^{269}$ Vickers, Farmers and Fishermen, 151.
} 
If we incorporate into our understanding of the nature of work in the commercial cod fisheries the sense that in many instances the same crews on the same vessels worked in various capacities for the same merchant employers, then it becomes clear why men would want to take on the additional responsibilities associated with being a skipper. In almost every case, merchant captains earned more, both in real wages and from the amount of privilege allowed, for trade voyages than their mates or common seamen. Merchants commonly trusted the same men who worked for them in the capacity of skipper to work for them as masters on trade missions. As a result, the role of skipper represented increased earnings potential for workers in the commercial fisheries. There was also an unquantifiable measure of prestige that went along with the responsibility of recruiting and commanding men on fishing expeditions and trade voyages.

In the final analysis, the eighteenth-century commercial fishing industry operated within an increasingly capitalist world system in which the means of production had shifted to the hands of the few, social relations were defined through waged labor, private property rights were clearly defined and rigidly enforced through the law, and surplus value was generated for sale in the marketplace. $^{270}$ Yet, the transition to capitalism did not occur at the same pace in every economic sector. Development occurred unevenly within different industries at different times in different places. The coal mining industry and textile industry in England seem to have developed rapidly to become full-fledged capitalist enterprises by the end of the eighteenth century despite stiff resistance from workers. ${ }^{271}$ The commercial fishing industry in New England, by contrast, had not fully integrated into the new world system in the eighteenth

\footnotetext{
${ }^{270}$ Immanuel Wallerstein, The Modern World-System I: Capitalist Agriculture and the Origins of the European World-Economy in the Sixteenth Century (New York: Academic Press, 1974); and Peter Linebaugh, The London Hanged: Crime and Civil Society in the Eighteenth Century, $2^{\text {nd }}$ ed., (London: Verso, 2003).

${ }^{271}$ Ralph Davis, The Rise of the Atlantic Economies (New York: Cornell University Press, 1973); and Thompson, The Making of the English Working Class.
} 
century. Ownership of the means of production had shifted away from the many workers to the few merchants and time-oriented work patterns were market-driven. Yet, wage labor did not completely define social relations and occupational identity had not been fully standardized in the cod fisheries. Instead, workers preferred the share and count system to wage labor in the fishing industry, and many men were jacks-of-all trades. Moreover, in terms of structural organization, vertical integration was rarely achieved and was almost never complete. Merchants in different ports at different times relied upon others for various catching, drying, and shipping services. Until we develop a definition of a fisherman that encapsulates the diverse experiences many men went through, we will never truly understand what it meant to work in the commercial fishing industry.

Based on the foregoing look at the fishing industry, it seems clear that a commercial fisherman during the second half of the eighteenth-century in Massachusetts operated in a vernacular capitalist industry in which the means of production were controlled by relatively few individuals, and in which there were few standardized occupational identities. He experienced labor at sea on fishing expeditions and trade voyages, and labor on land at a variety of short-term tasks. Throughout the labor process involved in catching, processing, and shipping cod, he faced a variety of risks and physical demands. He also experienced varying degrees of exploitation, and he earned compensation of several types and degrees.

As will be shown in later chapters, the occupational diversity that was part-and-parcel of the eighteenth century commercial fishing industry in Massachusetts proved of great consequence for the American Revolutionary War. Indeed, the same schooner Polly that opened this chapter was used as a U.S. Naval vessel during the Revolution, and Burnham, its skipper, became a revolutionary official. On December 7, 1776, he shipped as master and agreed "to 
Follow all the regulations of the American Congress \& be under such regulations as is Customary for Seamen \& Mariners.”272 The switch from one maritime pursuit to another would not have been unusual for a worker who had made his living from the sea as a jack-of-all trade. Indeed, many men such as Burnham were employed in revolutionary activities because of their wide-based skill set. In order to explain why such men decided to put their diverse skills to use in resisting British authority during the imperial crisis we must first step back and analyze the rise of the New England cod fisheries in the Atlantic economy.

272 Joshua Burnham Papers, 1758-1817, Schooner Polly, 1771-1776, Box 1, Folder 4, JDPL. 


\subsection{THE RISE OF THE NEW ENGLAND COD FISHERIES IN THE ATLANTIC ECONOMY}

"The lumber and provisions of the American colonies were more necessary to the West India islands than the rum and sugar of the latter were to the former." - Adam Smith to William Eden, December 15, $1783 .^{1}$

There is a scholarly consensus that an integrated Atlantic economy emerged between 1650 and $1750 .^{2}$ Trade routes were organized and consolidated during this period, connecting diverse markets and peoples. Timetables were defined in such a way as to minimize extraneous costs that came with overseas transport and quicken the circulation of information and commodities. The proliferation of maps, globes, and marine atlases at this time also helped overcome difficulties associated with transoceanic shipping. ${ }^{3}$

\footnotetext{
${ }^{1}$ E.C. Mossner and Ian Simpson, eds., Correspondence of Adam Smith (Oxford: Oxford University Press, 1977), 271.

${ }^{2}$ See, Peter A. Coclanis, ed., The Atlantic Economy During the Seventeenth and Eighteenth Centuries: Organization, Operation, Practice, and Personnel (Columbia, SC: University of South Carolina Press, 2005); John J. McCusker and Kenneth Morgan, eds., The Early Modern Atlantic Economy (Cambridge: Cambridge University Press, 2000); Susan Socolow, ed., The Atlantic Staple Trade, 2 vols., (Aldershot, U.K.: Variorum, 1996); David Hancock, Citizens of the World: London Merchants and the Integration of the British Atlantic Community, 17351785 (Cambridge: Cambridge University Press, 1995); Alan K. Smith, Creating a World Economy: Merchant Capital, Colonialism, and World Trade, 1400-1825 (Boulder, CO.: Westview Press, 1991); Jacob M. Price, "The Transatlantic Economy,” in Jack P. Greene and J.R. Pole, eds., Colonial British America: Essays in the New History of the Early Modern Era (Baltimore: Johns Hopkins University Press, 1984), 18-42; Immanuel Wallerstein, The Modern World-System I: Capitalist Agriculture and the Origins of the European World-Economy in the Sixteenth Century (New York: Academic Press, 1974); and Ralph Davis, The Rise of the Atlantic Economies (Ithaca, New York: Cornell University Press, 1973).

${ }^{3}$ Ian K. Steele, The English Atlantic 1675-1740: An Exploration of Communication and Community (Oxford: Oxford University Press, 1986), esp. Part II, “Commanding Time,” 113-209, and 213-228.
} 
Certain commodities have been privileged in economic histories of the Atlantic world. Sugar, especially, has been viewed as a catalyst for global economic expansion. ${ }^{4}$ As European entrepreneurs sought new and more fertile lands to produce this sweet confection and its byproducts, western territories off the coast of Africa and across the Atlantic Ocean into the Western Hemisphere were conquered. Native peoples were either killed or enslaved, and sugar plantations sent out shipments bound for European markets. Other consumer goods such as wine and tobacco have also been revealed as playing a role in connecting diverse regions and peoples around the Atlantic world in an ever-tighter global web. ${ }^{5}$ The role that the commercial cod fishing industry played in this process has been understudied. ${ }^{6}$

Only two works have systematically treated the connections between commercial cod fishing and the Atlantic economy. In 1940, Harold Adams Innis published his broad-sweeping classic overview, The Codfisheries: The History of an International Economy. ${ }^{7}$ Innis examined the historically competitive nature of the fishing industry and argued that the production of dried cod benefited the economies of different regions. Through extensive research in Spanish,

\footnotetext{
${ }^{4}$ Stuart B. Schwartz, ed., Tropical Babylons: Sugar and the Making of the Atlantic World before the 'Sugar Revolution' (Chapel Hill: The University of North Carolina Press, 2004); Stuart B. Schwartz, Sugar Plantations in the Formation of Brazilian Society: Bahia, 1550-1835 (Cambridge: Cambridge University Press, 1985); Sidney W. Mintz, Sweetness and Power: The Place of Sugar In Modern History (New York: Viking Press, 1985); Richard S. Dunn, Sugar and Slaves: The Rise of the Planter Class in the English West Indies, 1624-1713, $2^{\text {nd }}$ ed., (New York: W.W. Norton \& Company, Inc., 1973); and Richard B. Sheridan, Sugar and Slavery: An Economic History of the British West Indies, 1623-1775 (Baltimore: The Johns Hopkins University Press, 1973).

${ }^{5}$ For wine, see David Hancock, “'A Revolution in the Trade': Wine Distribution and the Development of the Infrastructure of the Atlantic Market Economy, 1703-1807,” in McCusker and Morgan, eds., The Early Modern Atlantic Economy. For tobacco, see Jacob M. Price, Tobacco in Atlantic Trade: The Chesapeake, London and Glasgow, 1675-1775 (Brookfield, VT: Variorum, 1995); and Paul G. E. Clemens, The Atlantic Economy and Colonial Maryland's Eastern Shore: From Tobacco to Grain (Ithaca, NY: Cornell University Press, 1980).

${ }^{6}$ Coclanis edited chapters on wine, cloth, tobacco, rice, and indigo, but not cod. Similarly, McCusker and Morgan brought together historians who focused on wine, sugar, rum, and tobacco, but not cod. Socolow edited chapters focusing on all of these staples, in addition to chocolate, spermaceti, and cochineal, but not cod. David Hancock does not even mention the fisheries. Price admits "I have had to neglect some important subjects, including fishing and fish exports.” Price, "The Transatlantic Economy,” 39. Immanuel Wallerstein only mentions the industry once. Wallerstein, The Modern World-System I, 281. Ralph Davis does not discuss the commercial fishing industry in any systematic way.

${ }^{7}$ Harold Adams Innis, The Codfisheries: The History of an International Economy (New Haven: Yale University Press, 1940).
} 
French, and English archives, he demonstrated that from the sixteenth century to the twentieth century various European powers fought for access to the same fishing grounds. Much more recently, Peter Pope has argued that the trade in cod for Madeira wine effectively established a North Atlantic triangular trade as early as the seventeenth century. ${ }^{8}$ The focus of both these excellent works, however, is on Newfoundland.

This chapter will situate the colonial New England fishing industry within the broader framework of an Atlantic economy. First, the role that cod played in the rise of an integrated, multi-regional economic system will be examined. Then, the chapter will investigate the expansion of the New England fisheries within this system and discuss change and continuity in the Atlantic cod trade. It will be demonstrated that cod was the basis of an organized Atlantic economy from at least as early as 1600 . The primary function of this valuable commodity in a supra-imperial system of supply and demand shifted between the seventeenth and the eighteenth centuries as a result of a variety of factors that will be examined in detail. Such a shift weakened English capital's financial control over its periphery in New England and expanded colonial maritime commerce. To be sure, cod was never the most lucrative of Atlantic commodities. ${ }^{9}$ However, its importance as a source of food for slave labor and as New England's primary means of exchange in the Atlantic marketplace cannot be ignored.

\footnotetext{
${ }^{8}$ Peter E. Pope, Fish Into Wine: The Newfoundland Plantation in the Seventeenth Century (Chapel Hill: The University of North Carolina Press, 2004). In his early discussion of "the Atlantic basin" Charles McLean Andrews noted that "fish" was one of five major "groups of economic commodities." Charles M. Andrews, "Anglo-French Commercial Rivalry, 1700-1750: The Western Phase, I,” The American Historical Review, Vol. 20, No. 3 (April, 1915), 546. The other four commodity "groups" he mentioned were slaves, tropical and semi-tropical products (including sugar, tobacco, and indigo), furs, and naval stores.

${ }^{9}$ New England fish ranked sixth in terms of the value of British North American and Caribbean exports, 17641775, behind sugar products, tobacco, Newfoundland fish, bread and flour, and rice, in that order. See, Stephen J. Hornsby, British Atlantic, American Frontier: Spaces of Power In Early Modern British America (Hanover: University Press of New England, 2005), 26-28, esp. Figure 2.1.
} 


\subsection{WESTWARD EXPANSION AND THE RISE OF THE ATLANTIC COMMERCIAL COD FISHING INDUSTRY}

Cod used to flourish in the North Sea and Atlantic waters between Norway and Massachusetts. Gadus morhua are characterized by five fins, a protruding upper jaw on a head that takes up one fourth of its body length, a heavy body and a square tail. They are demersal fish that feed on crustaceans and other smaller forms of sea-life that eat plankton on the bottom of the ocean, usually along continental shelves near upwellings of cold water. Cod migrate to inshore waters to spawn, as the food is more abundant there and they generally reproduce more efficiently in warmer waters than cold. They can grow to weigh over 200 pounds, but are usually found less than 50 pounds. Their flesh is almost purely white, and it is an unusually rich protein source. Taken wet, right out of the ocean, cod contain $18 \%$ protein. Dried cod filets with the water weight evaporated can contain $80 \%$ protein. ${ }^{10}$ Such protein has made dried cod highly desirable in the marketplace.

Early modern commercial fishing operations took in cod and, after processing, transported the catch to markets around the Atlantic world. The earliest recorded commercial cod fishing ventures in the Atlantic Ocean were conducted off the coast of Ireland around 1200 AD. ${ }^{11}$ To be sure, ancient European peoples had been fishing in the Atlantic Ocean for

${ }^{10}$ Pope, Fish Into Wine, 24; Mark Kurlansky, Cod: A Biography of the Fish that Changed the World (Canada: Alfred A. Knopf, 1997), 32-45; Innis, The Codfisheries, 1-6; and Raymond McFarland, A History of the New England Fisheries (New York: D. Appleton \& Company, publishers for the University of Pennsylvania, 1911), 4.

${ }^{11}$ Todd Gray, "Fisheries to the East and West," in "The Distant-Water Fisheries of South West England in the Early Modern Period,” in David J. Starkey, Chris Reid, and Neil Ashcroft, eds., England's Sea Fisheries: The Commercial Sea Fisheries of England and Wales since 1300 (London: Chatham Publishing, 2000), 97; and Robb Robinson and David J. Starkey, "The Sea Fisheries of the British Isles, 1376-1976," in Poul Holm, David J. Starkey and Jón Thór, eds., The North Atlantic Fisheries, 1100-1976 (Esbjerg: Fiskeri- og Søfartsmuseets, 1996), 121-143. It is important to note that Gray sees the origins of the medieval commercial English fishing operations to the west, in the Atlantic Ocean, in earlier ventures in the eastern Channel and the North Sea. Commercial cod fishing was 
subsistence for thousands of years. ${ }^{12}$ Yet, sustained efforts to harvest the fruits of the Atlantic and convert surplus cod into a saleable commodity for consumption in the marketplace began only in the medieval period. ${ }^{13}$ It is probably no coincidence that Venetian merchants were establishing slave-run sugar plantations in the Mediterranean just prior to the initial westward expansion of European commercial fishing activities in the Atlantic. The addition of slave plantations may have established markets for lesser grades of cod fish. ${ }^{14}$

Irish fish merchants traded directly with France, Spain and Portugal as early as the thirteenth century. Warmer waters provided a comparative advantage here, as opposed to the colder North Sea, enabling longer fishing seasons and the catch of additional species. Once the season had ended, Irish fishermen and fishing vessels transported catches and hides to ports in these regions to exchange for salt, iron, and wine. ${ }^{15}$ Commercial cod fishing around Ireland developed slowly until the turn of the fifteenth century. ${ }^{16}$ Ireland's maritime resources were increasingly exploited from abroad, and in 1430 Irish chieftains complained about the expanded activities of fishermen from England, Wales, Scotland, Brittany, Gascony, the Netherlands, and

active in the North Sea from the fourteenth century. See, Wendy R. Childs, "The Eastern Fisheries," in "Fishing and Fisheries in the Middle Ages,” in Starkey, Reid, and Ashcroft, eds., England's Sea Fisheries, 22.

${ }^{12}$ According to Barry Cunliffe, Mesolithic period settlers along the south-west coast of Scotland hand-lined for fish in the Atlantic Ocean between 7,000 and 5,000 B.C. Barry Cunliffe, Facing the Ocean: The Atlantic and its Peoples, 8000BC-AD1500 (Oxford: Oxford University Press, 2001), 124-127, 156-158.

${ }^{13}$ Mark Kurlansky believes Vikings were taking Atlantic cod, processing catches, and selling surplus in European markets as early as the ninth century. Kurlansky, Cod, 21. There is, however, no evidence for these early commercial ventures.

${ }^{14}$ Cunliffe, Facing the Ocean, 529-530; Philip D. Curtin, The rise and fall of the plantation complex, $2^{\text {nd }}$ ed., (Cambridge University Press, 1998), 4-5. Venice and Genoa, major financial centers for Mediterranean sugar production, were trading with English ports from the thirteenth century, and cod may have been involved. The historical relationship between commercial fishing and slavery needs more scholarly attention.

${ }^{15}$ Cunliffe, Facing the Ocean, 537.

${ }^{16}$ Maryanne Kowaleski, "The Western Fisheries," in "Fishing and Fisheries in the Middle Ages," in Starkey, Reid, and Ashcroft, eds., England's Sea Fisheries, 23. Kowaleski attributes this initial slow growth "to the later settlement of much of western Britain which, in turn, led to lower population, income and wealth levels. Such factors, together with the distance of the west from continental markets, and the volatile political scene (notably in Wales), conjoined to stymie investment.” Ibid. 
Iberia. ${ }^{17}$ Maryanne Kowaleski notes that "by the second half of the sixteenth century, some 600 Spanish ships were reputedly sailing to Ireland to fish each year. ${ }^{18}$ Herring, hake, cod, ling, and salmon were all taken around Ireland and sold commercially throughout Europe and the Mediterranean. As early as the fifteenth century, English fishermen operated on a share system in which they received an agreed upon portion of the profits from the sale of the catch. ${ }^{19}$ The share system would dominate England's fishing industry until well into the eighteenth century.

The principal demand for fish in Europe during the medieval period stemmed from those unable to afford meat, and from pious Catholics unwilling to violate feast day and Lenten prohibitions. $^{20}$ These markets were supplied with small amounts of fresh fish. According to Wendy R. Childs, in the fourteenth century "the bulk of the international market was in the preserved variety, whether salted, dried, or smoked. Herring and cod were the most commonly preserved species, though others such as hake were also dried and salted.”21

Some of this dried fish was processed using an innovative cure developed in the Netherlands during the late fourteenth century. This practice involved partially gutting, salting, and packing the catch in barrels at sea, then repacking the fish on shore to adjust for moisture loss. The entire process enabled fishermen to work at sea for longer periods and haul in more

\footnotetext{
${ }^{17}$ While some Basque, Portuguese, and Spanish fishermen were able to reach these waters, contrary trade winds and ocean currents prevented Iberians from penetrating the Atlantic in any substantive way until well into the fifteenth century. John Thornton, Africa and Africans in the Making of the Atlantic World, 1400-1800, $2^{\text {nd }}$ ed., (New York: Cambridge University Press, 1998), 13-17, 21-24; and Ralph Davis, The Rise of the Atlantic Economies (Cornell University Press, 1973), 5-7. Moreover, as Barry Cunliffe has noted, until the Muslim control of the Straits of Gibraltar was broken in the thirteenth century, Spain "turned its back firmly on the opportunities offered by the Atlantic.” Cunliffe, Facing the Ocean, 527.

${ }^{18}$ Ibid., 27.

${ }^{19}$ See, Kowaleski, “The Western Fisheries,” 28.

${ }^{20}$ Maryanne Kowaleski, "The Internal Fish Trade," in "The Internal and International Fish Trades of Medieval England and Wales," in Starkey, Reid, and Ashcroft, eds., England's Sea Fisheries, 29. For more on the important role fish played in the diet of many medieval Europeans, see C.M. Woolgar, “'Take This Penance Now, and Afterwards the Fare will Improve': Seafood and Late Medieval Diet,” in Starkey, Reid, and Ashcroft, eds., England's Sea Fisheries, 36-44.

${ }^{21}$ Wendy R. Childs, "Control, Conflict and International Trade," in “The Internal and International Fish Trades of Medieval England and Wales,” in Starkey, Reid, and Ashcroft, eds., England’s Sea Fisheries, 33.
} 
fish. Overall, the Dutch cure provided a durable commodity for overseas transport. ${ }^{22}$ At this time, salt for the cure was purchased from Germanic, English, Dutch, French, and Italian suppliers. ${ }^{23}$ New vessel designs, such as the fifteenth century development of the Dutch buss and the lateen-rigged caravel, together with new navigational equipment such as the quadrant for determining latitude, further encouraged the prosecution of the Atlantic fishing industry. ${ }^{24}$

Commercial cod fishing expanded westward to the shores of Iceland as maritime technology was being revolutionized. By the fifteenth century, Scandinavian, English, and perhaps some Portuguese were working the artic waters off Iceland. ${ }^{25}$ From the late fourteenth and early fifteenth centuries the united kingdoms of Denmark and Norway controlled the region first explored by Thorwald and his unruly son Eirik the Red. The Norwegian monarchical state attempted to regulate the Icelandic cod fish trade, making Bergen a port through which all such fish had to pass and be taxed. The Danes were particularly unwilling to abide foreign

${ }^{22}$ For more on the Dutch cure, see R.W. Unger, "The Netherlands Herring Fishery in the late Middle Ages: the False Legend of Willem Beukels of Biervliet," Viator, Vol. 9, (1978), 335-356. Although the cure was developed for use in Dutch North Sea herring fisheries, it was extended to other types of fish and used in the taking of cod in Atlantic waters around medieval Ireland. See, Kowaleski, “The Western Fisheries,” 27.

${ }^{23}$ Robert P. Multhauf writes that in the fourteenth century, "in the Low Countries salt was extracted from saltrich coastal peat, and in England by boiling down sea water all along the coast. Both of these sources declined in the fifteenth century: the Low Countries because of the exhaustion of peat and England because of the loss of labor to the growing textile industries. These sources were succeeded by 'bay salt,' a product of solar evaporation of sea water along the French Atlantic coast... where salt production began to flourish about 1370.” Robert P. Multhauf, Neptune's Gift: A History of Common Salt (Baltimore: The Johns Hopkins University Press, 1978), 9.

${ }^{24}$ According to Jan De Vries and Ad Van Der Woude, "the development of the herring buss, a veritable factory ship on which the herring were not only caught but processed on board, is undoubtedly one of the seminal innovations of the fifteenth century, and it played a leading role in the economic rise of the new [Dutch] Republic at the end of the sixteenth century." Jan De Vries and Ad Van Der Woude, The First Modern Economy: Success, Failure, and Perseverance of the Dutch Economy, 1500-1815 (Cambridge University Press, 1997), 243. For an exact description of a buss, see Simon Smith, Agent for the English Royal Fishing Company, The Herring Busse Trade, expressed in Sundry particulars (London, 1641). For more on the importance of the quadrant and lateen rigged caravel, which was also used for exploration and transporting slaves, see Davis, The Rise of the Atlantic Economies, 6, 12; A. J. R. Russell-Wood, The Portuguese Empire, 1415-1808: A World On The Move, $2^{\text {nd }}$ ed., (Baltimore: The Johns Hopkins University Press, 1998), 28-29; and C.R. Boxer, The Portuguese Seaborne Empire: 1415-1825 (New York: Alfred A. Knopf, 1969), 21, 27-28.

${ }^{25}$ For evidence that Christopher Columbus, sailing a Portuguese-owned vessel, ventured to Iceland in 1477, see Samuel Eliot Morison, Admiral of the Ocean Sea: A Life of Christopher Columbus, $2^{\text {nd }}$ ed., (New York: Time Incorporated, 1962), 21-23. It is not known what type of vessel this was, or why the Portuguese were there. 
encroachments. They initially forbid foreigners to over-winter on the Island, and in 1426 attempted to ban foreign fishing vessels from working Icelandic waters. The Danes were hoping to promote their own trade in stockfish, cod that was wind-dried on Icelandic shores. When their prohibitions failed, the Danes tried to sell and enforce fishing licenses. Denmark and Norway were also members of the Hanseatic League, a mercantile confederacy uniting more than two hundred towns from the Rhine to the Gulf of Finland that dominated the North Sea and Baltic trades. The League reduced Bergen's access to foreign shipping, further restricting Icelandic cod. Despite these attempts to keep Iceland as a Hanseatic preserve, fifteenth century English fishermen continued to take in cod all around the island, and even erected temporary fishing stations on its shores to salt and barrel catches. ${ }^{26}$

The influx of Icelandic cod transformed England's economy. ${ }^{27}$ According to Kowaleski, cod increased English foreign trade with Catholic regions in France and the Mediterranean, and turned the ports of Devon and Cornwall into "the biggest fish exporters in fifteenth-century England." ${ }^{28}$ Icelandic cod may have been responsible for opening up trade networks in Spain, as well, for it was around the turn of the fifteenth century that English merchants became active in Seville and Bilbao, where the demand for fish would have given the English cod merchants

\footnotetext{
${ }^{26}$ Wendy Childs, “England's Icelandic Trade in the Fifteenth Century: The Role of Hull," in Poul Holm, Olaf Janzen, and Jón Thór, eds., Northern Seas Yearbook 1995, Association for the History of the Northern Seas, (Esbjerg, Denmark: Fiskeri- og Søfartsmuseet, 1995), 11-31; Cunliffe, Facing the Ocean, 539-541.

${ }^{27}$ There is a debate among English scholars as to which part of England was most responsible for conducting fishing operations off Iceland in the fifteenth century. James A. Williamson maintains Bristol merchants were the driving force behind these north Atlantic fisheries. James A. Williamson, A Short History of British Expansion: The Old Colonial Empire, $3^{\text {rd }}$ ed., (London: MacMillan and Co., limited, 1945), 68. More recently, Wendy Childs has promoted Hull as the commercial leader in these artic enterprises. Childs, "England's Icelandic Trade in the Fifteenth Century: The Role of Hull.” For his part, Evan Jones has shown a shift in the center of this commerce from the West Country to East Anglia in the sixteenth century. Evan Jones, "England's Icelandic Fishery in the Early Modern Period,” in Starkey, Reid, and Ashcroft, eds., England's Sea Fisheries, 106.

${ }^{28}$ Kowaleski, “The Western Fisheries,” 28.
} 
leverage. ${ }^{29}$ The economic costs of fishing around Iceland remained, however, and merchants began seeking waters further west beyond the reach of the Hanseatic League. ${ }^{30}$

Merchants in Bristol, England took the lead in this search and financed at least one major expedition to explore the seas west of Iceland in $1497 .^{31}$ They sponsored Venetian explorer John Cabot's discovery of Newfoundland, "the new found land," "terre neuve," or "terra do bacalhau," Portuguese for the land of cod. ${ }^{32}$ Bristol is located in South-Western England in a region known as the West Country.

The West Country has had a long and well-documented relationship with the Atlantic cod fishing industry. ${ }^{33}$ Ports such as Bristol, Plymouth, Barnstaple, Dartmouth, Poole, and Teignmouth were ideally located to prosecute the fisheries to the westward. On a small scale, fishermen from these ports had previously worked waters off Ireland and Iceland. It was not until the late sixteenth and early seventeenth centuries that West Country ports came to dominate

${ }^{29}$ Cunliffe, Facing the Ocean, 533-534.

${ }^{30}$ Stephen J. Hornsby argues that "the stimulus" behind England's westward Atlantic expansion was the search for additional trade goods for use in Spanish markets in exchange for East Asian spices. Hornsby, British Atlantic, American Frontier, 13-14. Hornsby largely ignores other factors, such as Hanseatic pressures.

${ }^{31}$ David Harris Sacks, The Widening Gate: Bristol and the Atlantic Economy, 1450-1700 (Berkeley: University of California Press, 1991), 34-36. For more on speculations about pre-Cabotian Bristol voyages to Newfoundland, see K. R. Andrews, Trade, Plunder and Settlement: Maritime Enterprise and the Genesis of the British Empire, 1480-1630 (Cambridge: Cambridge University Press, 1984), 44-47. Kurlansky feels very strongly that the Basques were working Newfoundland waters long before Cabot's voyage. Kurlansky, Cod, 17-29. Yet, in the most recent scholarly work on early Newfoundland, Peter Pope dismisses these early voyages, particularly the Basque ventures: "The notion of pre-Columbian Basque fishers in Newfoundland waters is a recurring fantasy of writers with more interest in a good story than in the evidence.” Pope, Fish Into Wine, 17, fn. 7.

${ }^{32}$ For the various sixteenth century names for Newfoundland, see Pope, Fish Into Wine, 15.

${ }^{33}$ For a concise overview of the role West Country ports played in the medieval and early modern cod fishing industry, see Todd Gray and David J. Starkey, "The Distant-Water Fisheries of South West England in the Early Modern Period,” in Starkey, Reid, and Ashcroft, eds., England's Sea Fisheries, 96-104. There is a vast literature on the role West Country merchants played in the cod fisheries around Newfoundland. For a concise overview, see Hornsby, British Atlantic, American Frontier, ch. 2. For the seventeenth century in particular, see Pope, Fish Into Wine, esp., 144-149. For the eighteenth and nineteenth centuries, see W. Gordon Handcock, Soe longe as there comes noe women: Origins of English Settlement in Newfoundland (St. Johns, Newfoundland: Breakwater Books, 1989), esp. 53-69, and Table 3.1. For more on the role West Country fish merchants played in the settlement of New England, see Phyllis Whitman Hunter, Purchasing Identity in the Atlantic World: Massachusetts Merchants, 1670-1780 (Ithaca, NY: Cornell University Press, 2001), 33-70; Sacks, The Widening Gate, 50, 101-103; and Bernard Bailyn, The New England Merchants in the Seventeenth Century, 3rd ed., (Cambridge, Mass.: Harvard University Press, 1982). 
the English industry. ${ }^{34}$ Once Cabot's discoveries were made known throughout Europe an international race for waters teeming with cod began. ${ }^{35}$ Dried cod was the first staple the English developed in North America. Yet, the West Country merchants initially could not compete with the French in the Northwest Atlantic.

French fishermen were fastest out of the gate, and they took the lead in catching cod off Newfoundland. French fish merchants' sophisticated financial organization and local supplies of salt may have given them an edge over the competition in terms of prosecuting the Newfoundland fishing waters. Indeed, in 1545 France was even exporting a portion of their annual catch to England. ${ }^{36}$ The French would not relinquish this commanding position until the end of the Seven Years' War. ${ }^{37}$

Despite the discovery of Newfoundland and Hanseatic claims to Icelandic waters the majority of English cod fishing operations remained off Iceland throughout the sixteenth century. ${ }^{38}$ England and Portugal sent joint fishing ventures to the land of cod early in the 1500s, and a syndicate, “The Company Adventurers to the New Found Lands," formed in Bristol in

\footnotetext{
${ }^{34}$ Throughout the medieval period England's eastern fisheries in the North Sea represented the primary sector of economic activity. The western fisheries did not expand significantly until the fifteenth century. Wendy R. Childs and Maryanne Kowalski, "Fishing and Fisheries in the Middle Ages," in Starkey, Reid, and Ashcroft, eds., England's Sea Fisheries, 19-28.

${ }^{35}$ Raimondo de Soncino reported to the duke of Milan in a letter dated December 18, 1497 that he overheard Cabot state with regard to Newfoundland, "The sea there is swarming with fish.” Cited in Innis, The Codfisheries, 11. Also, see Sacks, The Widening Gate, 36. In this often cited letter, Cabot was reported to have found cod so plentiful he could take them by lowering a basket into the sea.

${ }^{36}$ Innis, The Codfisheries, 13, fn.13, and 40-41.

${ }^{37}$ Pope, Fish Into Wine, 19-20; Innis, The Codfisheries, 15-23, 49. According to Innis, 93 of the 128 recorded expeditions to Newfoundland prior to 1550 were French-owned vessels. Ibid., 19, fn. 35.

38 Jones, "England's Icelandic Fishery in the Early Modern Period," 105-110. It is Jones' primary contention that "although England's Icelandic fishery did disappear in the end, this did not happen until the late seventeenth century.” Ibid., 105. For more on England's lethargic involvement in the Newfoundland fisheries, see Pope, Fish Into Wine, 15-16; and Handcock, Soe longe as there comes noe women, 24.
} 
1501. ${ }^{39}$ Yet, the English struggled for market share in the international economy that formed around commercial cod fishing.

Cod caught off Newfoundland connected peoples and markets around the Atlantic world as early as the sixteenth century. According to Peter Pope:

By the later sixteenth century, European commercial activity in Atlantic Canada exceeded, in volume and value, European trade with the Gulf of Mexico, which is usually treated as the American center of gravity of early transatlantic commerce. The cod fishery was by far the most important component of European commercial activity in northern North America, and it would remain for centuries much more important than the trade in furs. ${ }^{40}$

Following their victory over Spain's armada, the English increased their attention on Newfoundland. Sixteenth-century English fishermen obtained salt from France or Portugal, caught cod off Ireland, Iceland, and Newfoundland, dry cured the catches, then sold the dried salted cod along Iberian and Mediterranean coasts in exchange for wine, oil, salt, and fruit. ${ }^{41}$ The Price Revolution and increased Catholic population levels helped lure merchantable grades of cod to Iberian ports. ${ }^{42}$ In 1578 there were an estimated 50 English fishing vessels working off the land of cod. By 1592 this figure had doubled. ${ }^{43}$

People from different nations met in the shipping lanes and fishing waters off the coast of Newfoundland. For their part, the French maintained a fishing fleet at Newfoundland that was

${ }^{39}$ Sacks, The Widening Gate, 49-50; Innis, The Codfisheries, 12.

${ }^{40}$ Pope, Fish Into Wine, 13-14. Also, see Sacks, The Widening Gate, 34-36, 48-50.

${ }^{41}$ Pope, Fish Into Wine, 14-15, 91. At the turn of the seventeenth century only ten percent of the fish taken by English hooks on an annual basis was consumed in England. See, Gray, "Fisheries to the East and West," 97.

${ }_{42}$ Andalusia remained one of the major markets for dried Atlantic cod, and between 1500-1520 and 1595-1605 the price of cod rose $929 \%$. During the same time periods, the general price index rose by $713 \%$. See, Earl J. Hamilton, "American Treasure and Andalusian Prices, 1503-1660: A Study in the Spanish Price Revolution," Journal of Economic and Business History, I (1928), 1-35, esp. 20-26; Innis, The Codfisheries, 51; and Davis, The Rise of the Atlantic Economies, 98-107. According to Davis, following the fourteenth century Black Plague that reduced the population of Western Europe by one third, the population of Europe doubled between 1460 and 1620 . Ibid., 16-17. The influx of New World gold and silver helped consumers meet these inflated prices.

${ }^{43}$ Gray, "Fisheries to the East and West," 97. 
at least twice the size of the English fleet at the end of the sixteenth century. ${ }^{44}$ Breton, Brittany, and Norman fishermen relied on their own salt supplies, and either lightly salted the Newfoundland catches, leaving them mostly wet, or "green," or they slightly air dried the cod before returning the fish to French fishmongers. The Basques also utilized the lightly salted airdried cure to process cod caught off Newfoundland, which they in turn sold to French and Iberian markets. $^{45}$ Portugal and Spain were primarily focused on exploiting the resources of Africa, the East Indies, the West Indies, and South America. Yet, these imperial powers did send fishing vessels to Newfoundland during the first half of the sixteenth century, possibly attempting to provision their expanding Atlantic empires in addition to meeting domestic consumption. The Iberian fishing fleets waned following political unification and the destruction of the Spanish armada. ${ }^{46}$ For their part, the Dutch consolidated their control over North Sea herring and the Atlantic carrying trade during the sixteenth century. ${ }^{47}$ They would invest capital and join in exploiting the waters around Newfoundland, but only later. ${ }^{48}$

\footnotetext{
${ }^{44}$ Pope, Fish Into Wine, 19-20. The French caught four times as much fish as the English off Newfoundland in 1664. See, David J. Starkey, "The Newfoundland Trade," in "The Distant-Water Fisheries of South West England in the Early Modern Period," in Starkey, Reid, and Ashcroft, eds., England's Sea Fisheries, 101, esp. Table 10.1.

${ }^{45}$ Pope, Fish Into Wine, 14.

${ }^{46}$ Innis, The Codfisheries, 19, fn. 35, and 38-39. It is Darlene Abreu-Ferreira's contention that the Portuguese presence was minimal throughout the sixteenth century. Abreu-Ferreira, "Notes and Comments: Terra Nova through the Iberian Looking Glass: The Portuguese-Newfoundland Cod Fishery in the Sixteenth Century," Canadian Historical Review 79, no.1 (1998): 100-115.

${ }^{47}$ Jonathan I. Israel, The Dutch Republic: Its Rise, Greatness, and Fall, 1477-1806, $4^{\text {th }}$ ed., (Oxford: Oxford University Press, 1998), 117, 325. By the 1620s, however, sizeable numbers of Dutch sack ships, freighters of 150300 tons that purchased direct from the fishermen on the open sea, were transporting cod caught and dried at Newfoundland to European and Mediterranean markets. See, Pope, Fish Into Wine, 96-97, 99.

${ }^{48}$ The Dutch expanded their maritime empire during first half of the seventeenth century. They carried European goods to East Asia, the Indian Ocean, Africa, South America, the West Indies, North America, and Newfoundland. Israel, The Dutch Republic: Its Rise, Greatness, and Fall, 1477-1806, esp. ch. 14. According to Russell-Wood, the Dutch were primarily responsible for displacing the Portuguese in the Indian Ocean and East Asia in the seventeenth century. Russell-Wood, The Portuguese Empire, 1415-1808, 128. Dunn maintains, "the Hollanders turned the Caribbean almost into a Dutch lake.” Dunn, Sugar and Slaves, 16. Large numbers of Dutch vessels frequented Newfoundland waters by the 1620s, not to fish for cod, but to trade. Their sack ships - large, armed vessels devoted solely to purchasing and freighting cargo - exchanged cash and credit for Newfoundland cod, which they then transported to Mediterranean, Iberian, and even French ports. For the derivation of the term "sack ship," see Pope, Fish Into Wine, 95. For more on the Dutch sack trade at Newfoundland, see Ibid., 98-103. Three
} 
The establishment of slave labor systems in the New World opened additional markets for dried cod. In England, plans had been made to ship North Atlantic dried cod to the slave plantations located on the Portuguese Atlantic islands (Madeira, the Canaries, and the Azores) in the sixteenth century, and the Portuguese may have conducted similar ventures at the end of the previous century. ${ }^{49}$ Yet, it was the emergence of large-scale plantations in the New World between the sixteenth and seventeenth centuries that generated more extensive markets for refuse grades of dried Atlantic cod fish. ${ }^{50}$ In their quest for the Spice Islands, Portugal, the Atlantic leader in producing slave labor and goods produced by slaves, turned increasingly away from fishing Northern waters themselves. By the end of the sixteenth century, Portugal and the Wine Islands were primarily importing dried cod from Newfoundland for domestic consumption and for re-export to the Brazilian plantations. ${ }^{51}$ In fact, this transatlantic re-export trade had become so lucrative that the Brazil Company was established in Lisbon in 1649 and awarded a monopoly

Anglo-Dutch wars in the second half of the seventeenth century eventually weakened Hollanders' maritime presence in western waters considerably.

${ }^{49}$ For sixteenth-century English plans, see Pope, Fish Into Wine, 91-92. It is not known precisely when lesser grades of dried cod began to be shipped to slave plantations, located in the Atlantic or the Mediterranean. However, there were sizeable slave populations on the Portuguese Atlantic islands during the 1500s. For the slave populations at sixteenth century Madeira and Grand Canary Island, see William D. Phillips, Jr., "The Old World background of slavery in the Americas," in Barbara L. Solow, ed., Slavery and the Rise of the Atlantic System (Cambridge:

Cambridge University Press, 1991), 50, 55. Europeans were certainly aware that these slaves generated demand for provisions. In the first half of the sixteenth century, João Lobato reported to the king of Portugal that slaves in São Tomé were running away due to food shortages on the island. See, John Thornton, Africa and Africans in the Making of the Atlantic World, 1400-1800, $2^{\text {nd }}$ ed., (New York: Cambridge University Press, 1998), 169. Moreover, Europeans were dry curing cod in the sixteenth century, and this process habitually yielded lesser grades of dried cod that could not be sold to free white Europeans.

${ }^{50}$ By all accounts, at the turn of the sixteenth century São Tomé contained the first modern, large-scale slave plantations. Even Robin Blackburn, who is at pains to link capitalism and modernity and stress the discontinuities between "Baroque" and "Modern" slave systems, acknowledges the early sugar plantations at São Tomé combined extensive capital investment with large-scale African gang slave labor. Robin Blackburn, The Making of New World Slavery (London: Verso Press, 1997), 111, 114. It is not known whether shipments of dried North Atlantic cod made it as far south as São Tomé. If they did, the cod would have found a ready market among the thousands of slaves there. In 1554, there were 2,000 slaves living and working on sugar plantations in São Tomé, in addition to 5-6,000 slaves awaiting the Middle Passage in baracoons. See, Schwartz, Sugar Plantations in the Formation of Brazilian Society, 13-14.

${ }^{51}$ Russell-Wood, The Portuguese Empire, 1415-1808, 125-126, 132; and T. Bentley Duncan, Atlantic Islands: Madeira, the Azores, and the Cape Verdes in Seventeenth-Century Commerce and Navigation (Chicago: University of Chicago Press, 1972), 127, 136, 154-155. 
on codfish imported into the colony. ${ }^{52}$ For their part, in 1636 the Dutch vessel de Cooninck freighted a load of dried cod from Newfoundland to Pernambuco, Brazil. ${ }^{53}$ The French, who dominated the sixteenth century Newfoundland cod fisheries, were routinely trading with Brazilian ports at this time. ${ }^{54}$ Moreover, from their initial English settlement, plantations at Jamaica and Barbados were provisioned with salt cod from the New England colonies. ${ }^{55}$ Toward the north, as early as the 1610s, hungry Virginian planters relied on shipments of dried North Atlantic cod. ${ }^{56}$ Prior to 1650 , then, and before permanent New England settlement, international cod fishing operations had integrated various Atlantic regions into a single economy fluctuating in rhythm with the sea. ${ }^{57}$

${ }^{52}$ Schwartz, Sugar Plantations in the Formation of Brazilian Society, 181. In 1600 there were between 1215,000 African slaves in Brazil, and many more native American slaves. Between 1600 and 1650, 200,000 African slaves were forcibly removed to Brazil. Blackburn, The Making of New World Slavery, 168.

${ }^{53}$ Pope, Fish Into Wine, 96. More will be said about the Dutch sack trade in the following sections.

${ }^{54}$ W.J. Eccles, The French in North America, 1500-1783, rev. ed., (East Lansing, Michigan: Michigan State University Press, 1998), 2-3, 8-9. According to Eccles, "the ports of northwest France were as much concerned with the Brazil trade as with the fishery of the Grand Banks.” Ibid., 2-3.

${ }^{55}$ Dunn, Sugar and Slaves, 276. Subsequent sections will cover this West Indian trade in more detail.

${ }^{56}$ James Wharton, The Bounty of the Chesapeake: Fishing in Colonial Virginia, $2^{\text {nd }}$ ed., (Charlottesville: The University Press of Virginia, 1973), 14, 22, 27-28; John Scribner Jenness, The Isles of Shoals: An Historical Sketch, $3^{\text {rd }}$ ed., (Boston: Houghton, Mifflin and Company, 1884), 20-22.

${ }^{57}$ Pushing the origins of the Atlantic economy back to the turn of the seventeenth century forces us to reevaluate the role the English Civil War played in bringing about this world system. It has been theorized that the rise of a "modern" fiscal-military state in England was fundamentally necessary for the integration of the Atlantic economy. See, Wallerstein, The Modern World-System I, 232, 256-257. According to Wallerstein, England took a leading role in this world systems shift, becoming a core with its own periphery, because bourgeois yeomen were able to seize political authority in the 1640s and set the nation on a decidedly commercial course in which state power was used to enforce private property rights. More recent scholarship has focused attention on earlier TudorStuart centralizing, "modernizing” tendencies, further complicating Wallerstein's paradigm. See, for example, Steve Hindle, The State and Social Change in Early Modern England, c.1550-1640 (New York: St. Martin's Press, 2000); and Michael J. Braddick, State Formation in Early Modern England, 1550-1700 (Cambridge: Cambridge University Press, 2000). 


\subsection{NEW ENGLAND'S BIOGEOGRAPHIC COMPARATIVE ADVANTAGES}

Resident New England commercial cod fisheries were born into this Atlantic world during the first half of the seventeenth century. The New England region enjoyed certain biogeographic comparative advantages over other sections of the New World with access to cod. Its temperate climate and proximity to fertile lands stimulated the formation of a mixed agricultural/maritime economy. Warmer water temperatures yielded larger species and longer fishing seasons off the north eastern seaboard of North America as compared to the North Atlantic waters surrounding Newfoundland. ${ }^{58}$ Bartholomew Gosnold, who voyaged in search of sassafras to the coast of what would become New England in 1602, sighted numerous fish close to shore. Gosnold noted that "in the months of March, April, and May, there is upon this coast, better fishing, and in as great plenty, as in Newfoundland....And, besides, the places...were but in seven fathoms [of] water and within less than a league of the shore; where, in Newfoundland they fish in forty or fifty fathoms [of] water and far off." ${ }^{59}$ The following year Martin Ping, an agent of West Country merchants in Bristol sent to investigate the possibilities of establishing a fishery in New England, provided his expert opinion that the region was ripe for such development. Ping reported: "We found an excellent fishing for cod which are better than those of Newfoundland and withal we saw good and rocky ground fit to dry them upon." ${ }^{60}$ Even the adventurous

\footnotetext{
${ }^{58}$ Commercial fishing around Newfoundland was restricted to a short summer season. Gray, "Fisheries to the East and West," 98. For more on the longer fishing seasons off the New England coast, see Daniel Vickers, Farmers and Fishermen: Two Centuries of Work in Essex County, Massachusetts, 1630-1830 (Chapel Hill: The University of North Carolina Press, 1994), 116; and Innis, The Codfisheries, 80. Peter Pope, a scholar currently living and working in Newfoundland, whose historical subject is Newfoundland, writes: "New England was, from the beginning, far wealthier and far more populous than Newfoundland and enjoyed key resource advantages, not the least of which were the lumber and naval stores that permitted the rapid development of an efficient shipbuilding industry.” Pope, Fish Into Wine, 159.

${ }^{59}$ H.S. Burrage, ed., Early English and French Voyages, Chiefly from Hakluyt, 1534 - 1658 (New York: C. Scribner's Sons, 1906), 331-332.

${ }^{60}$ Ibid., 345.
} 
Captain John Smith noted the particular suitability of the New England area for the fishing industry. "New England's fishings," he wrote, "are near land where is help of wood, water, fruits, fowls, corn, or other refreshments needful." ${ }^{61}$ William Wood, an English traveler who visited New England in 1634 wrote:

There is no country known that yields more variety of fish winter and summer, and that not only for the present spending and sustenation of the plantations, but likewise for trade into other countries, so that those which have had stages and make fishing voyages into those parts have gained (it is thought) more than the Newfoundland fishermen. Codfish in these seas are larger than in Newfoundland, six or seven making a quintal [112 lbs. dry weight], whereas there they have fifteen to the same weight. ${ }^{62}$

More northern regions proved less conducive to permanent fishing settlements.

The land of cod, in particular, was a harsh environment. Peter Pope, the leading authority on early Newfoundland fishing, describes the island's seventeenth-century climate as "subarctic;" its soil as "glaciated...youthful and shallow;" and its ecosystem as "restricted” and "simple." He further notes that such "biogeographic instability" was responsible for the disappearance of two native populations prior to the 1600 s. $^{63}$ Living conditions in Newfoundland were so challenging, in fact, that migratory English fishermen sent to live and work temporarily there often escaped to New England aboard trade ships. New England was a constant drain on Newfoundland's labor supply throughout the colonial period. ${ }^{64}$

${ }^{61}$ Edward Arber, ed., Travels and Works of Captain John Smith, President of Virginia, and Admiral of New England, 1580-1631, Vol. II, (New York: Burt Franklin, 1910), 712.

${ }^{62}$ William Wood, New England's Prospect, edited by Alden T. Vaughan, (Amherst, Mass.: University of Massachusetts Press, 1977; orig. pub. London, 1634), 53.

${ }^{63}$ Pope, Fish Into Wine, 45-46. For more on the "Inhospitable Environment" in Newfoundland, written by a Newfoundland scholar, see C. Grant Head, Eighteenth Century Newfoundland (Toronto: McClelland and Stewart Limited, 1976), 41-48; quote taken from the section's sub-title on 41. Innis, another Canadian scholar, reminds us that because New England maintained "a more favorable climate and an extensive hinterland" people there grew less dependent on the sea in the long run, while Newfoundland grew increasingly dependent on the fishing industry between the colonial and modern periods. Innis, The Codfisheries, 2.

${ }^{64}$ Handcock, Soe longe as there comes noe women, 29-30. 
For their part, early English settlers in colonial Virginia made attempts to overcome their chronic food shortages through subsistence and commercial fishing in the Chesapeake Bay. However, fish seemed to be most prevalent during hurricane seasons. The warm climate also made spoilage an endemic problem and stymied the industry’s development there. ${ }^{65}$ New England's biogeographic comparative advantages help explain why the first permanent resident fishing station was established in this region.

\subsection{WHY ENGLAND WAS THE FIRST TO ESTABLISH A RESIDENT FISHING STATION}

England was first to settle permanent resident fishing stations on the New England coast for a variety of reasons. The French, who had now become England's chief rival in catching cod, focused commercial activity around Newfoundland, the St. Lawrence Bay, and the St. Lawrence River. The furs in this region occupied their settlement plans and capital investment, and they seem to have been satisfied with the production of temporary, migratory fishing activities. ${ }^{66}$ Moreover, most major European powers were deeply embroiled in the Thirty Years War at this time. The fact that the English remained largely aloof from continental conflict may have contributed to their ability to finance and conduct settlement plans in the first half of the

\footnotetext{
${ }^{65}$ Wharton, The Bounty of the Chesapeake, 3, 6-13, 27. Virginians continued to supplement their diet with river fish throughout the colonial period. In the 1620s colonists in Virginia even attempted to send vessels to Newfoundland to trade tobacco for dried cod. By the mid-1600s, when Virginian planters made the decisive transition to slave labor, New Englanders were providing a steady stream of dried refuse grades of cod to Virginia. At this point, planters focused on tobacco production and abandoned ventures to the north for their own shipments of dried cod. It was more efficient for planters to purchase cod from New England suppliers as opposed to outfitting a vessel, purchasing marine insurance, buying and transporting the fish themselves, in addition to cultivating tobacco.

${ }^{66}$ Eccles, The French in North America, 1500-1783.
} 
seventeenth century. It is also important the early Stuart period witnessed increasing levels of state involvement in the English fishing industry. ${ }^{67}$ Due in part to their Scottish heritage, James I and his son were particularly keen on promoting the English fisheries at home and to the westward. ${ }^{68}$ Mounting population pressures further encouraged the Stuarts to authorize, and in some cases fund, plans to settle resident fishing stations in various parts of the New World. This was urgent because 1.5 million hungry mouths had been added to England’s population between 1500 and 1620, crowding the island with “idle hands” in need of employment. ${ }^{69}$

The expansion of West Country ports also stimulated the development of England's fishing industry. Although these ports maintained extensive commercial dealings only from the sixteenth century, merchants and fishermen from the West Country had been working the waters around Ireland and Iceland for hundreds of years. The accumulation of knowledge regarding where and when to fish, the organization of trade networks, and the concentration of capital contributed to the West Country's rise as a core in a world system formed in no small part

\footnotetext{
${ }^{67}$ During his reign, James I banned foreign fishing operations off English shorelines, and, when the ban failed, he decreed that foreign fishermen had to pay for licenses to fish in English waters and he levied a tax on all foreign fishermen. His son, Charles I formed his own royal fishing company in 1632 and built-up the navy to preserve his maritime sovereignty. John R. Elder, The Royal Fishery Companies of the Seventeenth Century (Glasgow: Glasgow University Press, 1912), 7, 8, 9, 11, 33; and Charles Wilson, Profit and Power: A Study of England and the Dutch Wars (London: Longmans, Green and Co., 1957), 37.

${ }^{68}$ For Scotland's historic relationship with commercial fishing in general, and the impact this history had on James I in particular, see James R. Coull, The Sea Fisheries of Scotland: A Historical Geography (Edinburgh: John Donald Publishers Ltd., 1996). For the Stuarts' roles in providing royal charters and granting exclusive fishing rights to various groups of early seventeenth century settlers, see Bailyn, The New England Merchants in the Seventeenth Century, 2-15.

${ }^{69}$ Population in France, Spain, and the Netherlands, by contrast, had peaked in the sixteenth century and was declining by 1600. Davis, The Rise of the Atlantic Economies, 91. Also, see John Brooke, "Ecology,” in Daniel Vickers, ed., Companion to Colonial America (Malden, Mass.: Blackwell Publishers Ltd., 2003), 53. Brooke writes: "Of any colonizing country, England exported far and away the greatest share of its population: half a million people in the seventeenth century.” According to Wilson, early seventeenth century English pamphleteers proposed commercial fishing would "give employment to the multitudes of Englishmen who ('through lewd idleness') were reduced to 'cheat, rob, roar, hang, beg, cart, pine and perish.'” Wilson, Profit and Power, 35. For evidence of this, see Tobias Gentleman, England's Way to Win Wealth, and to Employ Ships and Mariners (London, 1614).
} 
through cod. ${ }^{70}$ In addition to pre-existing pressures from the Hanseatic League at Iceland and

Newfoundland's harsh climate, demographic concerns, Continental warfare and state sponsorship, the rise of West Country ports enabled early seventeenth century English merchants to attempt plans for settling fishing stations in New England.

\subsection{THE BIRTH OF RESIDENT NEW ENGLAND FISHING STATIONS}

Initially, these plans for settlement either failed utterly, or succeeded only in maintaining temporary, migratory commercial fishing operations. ${ }^{71}$ It was not until 1631 that the first

\footnotetext{
${ }^{70}$ According to Immanuel Wallerstein, "three things were essential to the establishment of such a capitalist world-economy: an expansion of the geographical size of the world in question, the development of variegated methods of labor control for different products and different zones of the world-economy, and the creation of relatively strong state machineries in what would become the core-states of this capitalist world-economy." Wallerstein, The Modern World-System I, 38. All of these qualifications had been met prior to the successful establishment of a permanent resident fishing station in New England.

${ }^{71}$ According to Vickers, earlier attempts, including "Sagadahoc at the mouth of the Kennebec River (16071608), Wessagusset on the Massachusetts Bay (1622-1624), the Dorchester Company plantation on Cape Ann (1623-1624), and Mount Wollaston to the north of Plymouth (1623)," had all failed. Vickers, Farmers and Fishermen, 90. For more on these unsuccessful attempts at settlement, and the West Country capital backing them, see Gray, "Fisheries to the East and to the West," 98-100; Faith Harrington, “'Wee Tooke Great Store of Cod-fish': Fishing Ships and First Settlements on the Coast of New England, 1600-1630," in Emerson W. Baker, et al., eds., American Beginnings: Exploration, Culture, and Cartography in the Land of Norumbega (Lincoln: University of Nebraska Press, 1994), 191-216; Sacks, The Widening Gate, 101-103; John Frederick Martin, Profits in the Wilderness: Entrepreneurship and the Founding of New England Towns in the Seventeenth Century (Chapel Hill: University of North Carolina Press, 1991); Alaric Faulkner, “Archeology of the Cod Fishery: Damariscove Island,” Historical Archeology, Vol. 19, No. 2 (1985), 57-86; Edwin A. Churchill, "Too Great the Challenge: The Birth and Death of Falmouth, Maine, 1624-1676,” (Ph.D. Dissertation, University of Maine, 1979); Charles E. Clark, The Eastern Frontier: The Settlement of Northern New England, 1610-1763 (New York: Alfred A Knopf, 1970), 13-35; Bailyn, The New England Merchants in the Seventeenth Century, 2-15; Richard A. Preston, "Fishing and Plantation: New England in the Parliament of 1621," The American Historical Review, Vol. 45, No. 1 (October, 1939), 29-43; and McFarland, A History of the New England Fisheries, 38-56. There was some migratory fishing activity and attempts at settlement at the Isles of Shoals during the early 1620s. Jenness, The Isles of Shoals, 46-57. However, there is no evidence of successful permanent settlement there. Indeed, Captain Christopher Levett, an early English traveler to New England, wrote of the Isle of Shoals in 1623: "Upon these islands I neither could see one good timber tree, nor so much ground as to make a garden. The place is found to be a good fishing place for six ships, but more cannot well be there, for want of convenient stage room, as this year's experience hath proved. The harbor is but indifferent good." Ibid., 46-47. According to Christine Leigh Heyrman, "the Shoals settlements simply broke up as the island camps declined in importance as suppliers of fish by the end of the seventeenth century."

Commerce and Culture: The Maritime Communities of Colonial Massachusetts, 1690-1750 (New York: W.W.
} 
permanent commercial fishing station in the New World was established in Marblehead, Massachusetts. $^{72}$ Soon, Marblehead had company.

By the middle of the seventeenth century permanent resident fishing stations had been established all along the New England coastline. There were stations at Pemaquid, Portland, and Falmouth in the Maine province; Richmond Island and Monhegan Island off the coast of Maine; at the Isles of Shoals off the coast of Maine and New Hampshire; at Portsmouth in New Hampshire; at Cape Anne, Salem, Marblehead, and Ipswich in Massachusetts; and at Nantasket (renamed Hull), Scituate, and Cape Cod in Plymouth. ${ }^{73}$

These colonial fishing ports were firmly embedded in a transatlantic economic system with West Country ports situated at the core. West Country merchants responsible for moving

Norton \& Company, 1984), 229-230. Also, Port Royal, Acadia, has been called "France’s first permanent outpost in North America." Leslie Choquette, "Center and Periphery In French North America," in Christine Daniels and Michael V. Kennedy, eds., Negotiated Empires: Centers and Peripheries in the Americas, 1500-1820 (New York: Routledge, 2002), 195. However, Port Royal was abandoned between 1607 and 1610 . When it was resettled, the port functioned as much or more as a fur trading entrepot and agricultural settlement than as a fishing station.

${ }^{72}$ Christopher P. Magra, “'Soldiers...Bred to the Sea’: Maritime Marblehead, Massachusetts and the Origins and Progress of the American Revolution," New England Quarterly, Vol. LXXVIII, No. 4, (December 2004), 534; Vickers, Farmers and Fishermen, 90-92; Heyrman, Commerce and Culture, 207. Bernard Bailyn restricts his discussion to Salem, of which Marblehead was politically subservient to until 1649. Bailyn, The New England Merchants in the Seventeenth Century, 17-18. Robert G. Albion, William A. Baker, and Benjamin W. Labaree mistakenly refer to Marblehead as a "new settlement" in 1640. Robert G. Albion, William A. Baker and Benjamin W. Labaree, New England and the Sea (Mystic, Connecticut: Mystic Seaport Museum, Inc., 1972), 19. Raymond McFarland wrongly attributes "the first permanent settlement" to "Pemaquid in 1625," and mistakenly puts the date of "the first fishing station" in Marblehead at 1633. McFarland, A History of the New England Fisheries, 51, 52-53. Peter Pope makes a strong case that the Calvert experiment at Newfoundland between 1610 and 1629 did not fail utterly, as it left behind a certain amount of infrastructure for subsequent settlement. Pope, Fish Into Wine, esp. 4578. Yet, even Pope is forced to acknowledge the fact that Calvert and his servants decamped for warmer climes in Maryland. The number of resident fishermen in Newfoundland did not outnumber the migratory fishermen until the 1790s. Handcock, Soe longe as there comes noe women, 74-85, esp. Figure 4.2. In this chapter, a permanent resident fishing station is defined as an unbroken line of human settlement annually processing surplus cod for sale in markets.

${ }^{73}$ Vickers, Farmers and Fishermen, 92-100; Heyrman, Commerce and Culture, 34, 209-210; Bailyn, The New England Merchants in the Seventeenth Century, 78; Innis, The Codfisheries, 75, 116; McFarland, A History of the New England Fisheries, 38-64. Gloucester turned toward farming after 1660, and did not come back to fishing in a systematic way until the first half of the eighteenth century. Plymouth was united with Massachusetts in 1691. The New England commercial fisheries were located primarily north of Cape Cod. Time and energy necessary for travel around the Cape seems to have restricted commercial fishing in colonial Rhode Island. 
the Atlantic cod fisheries westward provided the capital necessary for all of these stations. ${ }^{74}$ Salem developed as an outfitter for fishermen while Boston acted as a central depot taking in catches from all the New England fishing stations. ${ }^{75}$ Bostonians and English agents living in Boston then negotiated the sale with ship captains, super cargoes, or the overseas merchants themselves. Finally, hogsheads of dried, salted cod were loaded onto West Country-Londonand-Boston-owned vessels and shipped overseas to foreign markets. ${ }^{76}$

Colonists were initially totally dependent on the capital and vessels associated with West Country merchants. A visitor to the province of Maine in the mid-seventeenth century recorded: “The fishermen take yearly on the coast many hundred quintals of cod, hake, haddock, pollock, etc., and dry them on their stages, making three voyages a year. They make merchantable and refuse fish, which they sell to Massachusetts merchants," who typically worked for West Country firms. ${ }^{77}$ The dependent status of colonial fishing stations lasted for some time. When Reverend John Barnard first came to Marblehead in 1714, he observed "the people contented themselves to be the slaves that digged in the mines and left the merchants of Boston, Salem, and Europe to carry away the gains."78 Merchants in outports commonly had coasters and fishermen transport the catches to Boston, where additional middlemen had merely been filling orders for,

\footnotetext{
${ }^{74}$ Gray, "Fisheries to the East and to the West," 98-100.

${ }^{75}$ Daniel Vickers, Young Men and the Sea: Yankee Seafarers In the Age of Sail (New Haven, Conn.: Yale University Press, 2005), 34-35.

${ }^{76}$ Vickers, Young Men and the Sea, 34, 42-43; Heyrman, Commerce and Culture, 227, 330; Innis, The Codfisheries, 79. By the end of the century, Boston was the third largest port in the British Empire. Bernard and Lotte Bailyn, Massachusetts Shipping, 1697-1714: A Statistical Study (Cambridge: Harvard University Press, 1959), 20-22.

${ }^{77}$ This quote can be found in McFarland, A History of the New England Fisheries, 58.

${ }^{78}$ Samuel Roads, Jr., The History and Traditions of Marblehead, Third ed. (Marblehead: N. Allen Lindsay \& Co., 1897). 42.
} 
and loading the ships of, West Country merchants. ${ }^{79}$ West Country control did not remain static or constant, however.

The first crack in the core's control over the New England periphery occurred during the English Civil War. Crisis at home disrupted England's maritime economy in general and its commercial fishing industry in particular, as fishing vessels were converted to warships and fishermen were pressed into naval service. Bristol, the largest port in the West Country, became a battleground and changed hands twice, in 1642 and 1644, between Parliamentarians and Royalists. The West Country fleets that traveled to Newfoundland grew smaller and smaller, and then stopped traveling to New England altogether. ${ }^{80}$ As a result, European markets became hungry for new suppliers and cod prices rose in several key European markets. ${ }^{81}$

New England merchants in the 1640s lacked the shipping, capital and overseas connections necessary to fill this vacuum on their own. However, London merchants eager to break the West Country's stranglehold on the fish trade had all of the commercial necessaries, and they began shipping manufactured goods, mostly textiles, to Boston on the first leg of what would become a regular triangular trade. In Boston, manufactured goods were exchanged with wholesalers for pre-arranged loads of dried cod, which were then shipped to ports in Iberia or the Portuguese Atlantic islands. The transatlantic shipments of cod primarily involved merchantable grades for domestic European consumption, but some refuse grade cod was also sold in Iberia, presumably for re-export to slave plantations given the small European slave populations. Once

\footnotetext{
${ }^{79}$ According to Vickers, "coasters were, by definition, professional seamen who had mastered the handling of smaller sailing vessels and now made their business freighting cargo up and down the coast where they lived." Vickers, Young Men and the Sea, 18.

${ }^{80}$ Vickers, Farmers and Fishermen, 98; and Bailyn, The New England Merchants in the Seventeenth Century, 77-78. According to Vickers, the West Country fleet working Newfoundland waters "fell from 340 vessels in 1634, to 270 in 1644, to fewer than 200 by 1652.” Ibid. For more on the Civil War's impact on Newfoundland, see Pope, Fish Into Wine, 132-44.

${ }^{81}$ Cod prices climbed by 25\% in Seville between 1637-1642 and 1644-1648, and rose 50\% in Madeira over the same periods. See, Vickers, Farmers and Fishermen, 98.
} 
the cod had been exchanged for fruits, solid specie, or lines of credit, the final leg of the triangle traversed to London. Fortunately for New Englanders, many London merchants were so eager to get in on this trade that they were willing to enter into partnerships with colonists, who increasingly built their own fishing vessels. Londoners' helped New Englanders gradually to gain control of the trade circuit. ${ }^{82}$

The bulk of New England exports of dried Atlantic cod in the seventeenth century were shipped to Spain, Portugal, and the Wine Islands, where this type of fish has always been highly valued for a variety of reasons: it could stay dried for extended periods; it proved exceptionally resilient to warm climates; it was extraordinarily durable during inland transport from coastal communities; and it was high in protein. Iberian ports were also attractive markets for fish because of the amount of solid specie that fish merchants could get in return. The principal economic function of the seventeenth-century colonial New England cod fisheries within the Atlantic economy was the transference of New World gold and silver into London coffers. ${ }^{83}$ In 1641, John Winthrop reported that 300,000 dried cod filets, or 6,000 quintals, were exported from Boston, the primary distribution center for New England, and almost all of it went to Iberian ports. ${ }^{84}$ In $1699,75 \%$ of the 50,000 quintals of dried cod exported from Boston went to

\footnotetext{
${ }^{82}$ John J. McCusker and Russell R. Menard, The Economy of British America, 1607-1789 (Chapel Hill, North Carolina: The University of North Carolina Press, 1985), 99-101; Bailyn, The New England Merchants in the Seventeenth Century, 78-82.

${ }^{83}$ Innis, The Codfisheries, 52, 74, 78. Captain John Smith famously stated: "Let not the meanness of the word fish distaste you, for it will afford us good gold as the mines of Guiana or Tumbata, with less hazard and charge, and more certainty and facility.” Cited in Wharton, The Bounty of the Chesapeake, 13. Also, a seventeenth-century French traveler had this to say on cod fishing at Newfoundland: "One can truly say that the best trade in Europe is to go and fish cod....you make good Spanish coin out of it and a million men live on it in France.” Cited in Fernand Braudel, The Structures of Everyday Life: Civilization \& Capitalism, $15^{\text {th }}-18^{\text {th }}$ Century, Volume 1, translated by Siân Reynolds, (New York: Harper \& Row, Publishers, 1979), 217-218.

${ }^{84}$ Vickers, Farmers and Fishermen, 99; and Bailyn, The New England Merchants in the Seventeenth Century, 78. It is important to note that Salem emerged as another distribution center, and primarily involved itself in the West Indian trade. This will be discussed in subsequent sections.
} 
Bilboa, Spain alone. ${ }^{85}$ These regions commanded the best prices for dried cod, or bacalao in Spanish. In 1642, bacalao fetched 14 shillings per quintal in Iberia and 8 shillings in the West Indies. And for the period between 1662 and 1685, for which price records are particularly good, cod was worth $27-44 \%$ more in Iberian ports than in West Indian ports. ${ }^{86}$ At no point during the colonial period did Southwestern Europe lose this comparative price advantage. The fact that New England cod could be winter-cured also gave it a small but important comparative advantage over Newfoundland cod, which was not typically dried during the winter months. ${ }^{87}$ Iberian markets for Atlantic cod were not new to the seventeenth century. This trade had been in existence since the Irish fisheries were established in the thirteenth century. The principal development here was that New Englanders were beginning to emerge as Iberian suppliers in place of West Country merchants.

Furthermore, New Englanders started to seize some market share around Newfoundland at the expense of West Country fish interests. As a result of Civil War in England, West Country migratory fishing fleets at Newfoundland witnessed a decrease in output from 250,000 quintals in 1615 to 170,000 quintals in $1675 .^{88}$ This decrease in production can be attributed primarily to

${ }^{85}$ Innis, The Codfisheries, 118; and McFarland, A History of the New England Fisheries, 69.

${ }^{86}$ Daniel Vickers, "'A Knowen and Staple Commoditie': Codfish Prices in Essex County, Massachusetts, 16401775," Essex Institute, Historical Collections, Vol. CXXIV, (Salem, MA: Newcomb and Gauss, 1988), 198-202, Table 1. In interpreting the data in this table I assume, following Vickers, that most of the merchantable grades of dried cod were shipped to Iberian ports, while most of the refuse grades were shipped to the West Indies. For Vickers on this score, see Ibid., 190.

${ }^{87}$ Innis, The Codfisheries, 118; and McFarland, A History of the New England Fisheries, 69. Cod cured in the winter months tended to be fresher at the point when it was dried, as opposed to the warmer months of the year. Thus, New England cod sold in the spring was supposed to taste better than cod caught at Newfoundland over the summer and cured in the fall. Yet, due to Newfoundland's proximity to Europe, the price of Newfoundland merchantable cod caught in the summer tended to be a shade higher throughout the seventeenth century. See, Pope, Fish Into Wine, 37-38, esp. Table 2.

${ }^{88}$ Starkey, "The Newfoundland Trade," 101-102. It is important to note that measurable output in the commercial fishing industry has always fluctuated from year-to-year. Yet, the West Country fishing ports did experience what Starkey refers to as "a prolonged depression" in mid-century as a result of the Civil War. It is also significant that production in New England was still in its infancy at this point, while fishing operations had been conducted around Newfoundland for over 150 years. As a result, the fact that the migratory Newfoundland output 
the fact that English migratory fishing fleets were dwindling. In 1605, the migratory fleet numbered some 250 vessels. By 1670, there were only 80 vessels in the transient fleet. ${ }^{89}$ The number of English sack ships declined during this period as well. Sacks had been responsible for supplying those hardy souls willing to overwinter on the island and the migratory fishing fleets that established temporary base camps in the region. New Englanders were able to capitalize on this weakened position of the West Country merchants, and expanded trade with Newfoundland during the second-half of the seventeenth century. They traveled in small but growing numbers to the northern island and exchanged provisions, lumber, rum, sugar, molasses, and tobacco for specie, lines of credit, fishing equipment, and various European goods. ${ }^{90}$

European expansion in the West Indies during mid-seventeenth century further stimulated the maritime commercial expansion of the New England cod fisheries. Europeans quickly conquered and divided the tropical islands. Between 1625 and 1650, England had settled Providence Island, Barbados, Nevis, Antigua, Montserrat, and part of St. Christopher’s Island. The French inhabited Guadeloupe, Martinique, the Tortugas, St. Martin, St. Lucia, St. Croix, Grenada, and the rest of St. Christopher, while the Dutch planted colonies at Curaçao, St. Eustatius, and Tobago. After destroying the ability of the native population to resist, or utterly

was almost three times the resident New England output in1675 should not be as poignant as the fact that a nascent New England expanded while an established Newfoundland contracted in the mid-seventeenth century.

${ }^{89}$ McFarland, A History of the New England Fisheries, 70.

${ }^{90}$ Pope, Fish Into Wine, 155-157; Bailyn, The New England Merchants in the Seventeenth Century, 129-130; Innis, The Codfisheries, 79-80; and McFarland, A History of the New England Fisheries, 70. Also, see Ralph Greenlee Lounsbury, "Yankee Trade at Newfoundland," New England Quarterly, Vol. 3, No. 4 (October, 1930), 607-626. The number of vessels entered at Boston's customs house as bound to Newfoundland increased from three in 1687 to eight in 1718, and then to twenty-four in 1730. Steele, English Atlantic, 297, Table 4.6.

England had recovered from its Civil War by the end of the seventeenth century, and expanded its naval power and its commercial presence in terra do bacalhau. Resilient West Country migratory fishermen began working the deeper waters of the Grand Bank off the land of cod around the turn of the eighteenth century. These bankers, along with bye-boat fishermen, men who left their vessels moored at Newfoundland only to hitch a ride as passengers back the following season, increased English production from 125,000 quintals in 1684 to 347,000 quintals in 1692. See, Starkey, “The Newfoundland Trade," 102-103. 
eliminating the natives altogether, Europeans began converting the land to the production of tradable commodities and bringing workers to the islands.

These workers needed to be fed, and cheaply so as not to reduce profit margins. After experimenting with various forms of white servitude, West Indian planters came to rely on a steady supply of black African slave laborers. Slave importation into Barbados exploded during the 1640 s as the island experienced what Richard Dunn has coined a "sugar revolution."91 In 1640 there were relatively few black African slaves on the island. Within ten years, 30,000 whites owned an estimated 12,800 such slaves and the island had become the leading sugar producer in the British Empire. In another ten years the number of slaves had more than doubled, and they outnumbered whites on the island. By 1690, there were nearly 48,000 slaves living and working on Barbadian sugar plantations, a figure representing $75 \%$ of the island's total population. ${ }^{92}$ Although no island converted to sugar production and slave labor as quickly as Barbados, Dunn writes, "all of the English and French islands inexorably followed the Barbadian example."93 In 1650 there were 15,000 black African slaves on all of the British West Indian islands, or $25 \%$ of the total population. Ten years later, there were 34,000 slaves, or $42 \%$ of the total population. By the end of the century 98,000 slaves lived and worked in the British West Indies. This figure represented $73 \%$ of the total population. ${ }^{94}$ The French sugar plantations expanded at a slower pace, which was to be expected given their capital commitment to Newfoundland fishing operations and New France exploration, fur extraction, and settlement. Yet, in 1664 the French West India Company was formed and given a monopoly for forty years, and by 1683 there were 19,346 slaves living and working on the French islands, including 2,102

\footnotetext{
${ }^{91}$ Dunn, Sugar and Slaves, 19.

${ }^{92}$ McCusker and Menard, The Economy of British America, 1607-1789, 150-153, esp. Table 7.1.

${ }^{93}$ Dunn, Sugar and Slaves, 20.

${ }^{94}$ McCusker and Menard, The Economy of British America, 1607-1789, 154, Table 7.2.
} 
slaves on the newly planted St. Domingue. ${ }^{95}$ Domestic food production could not meet the needs of the increasing numbers of slaves on these West Indian plantations.

As planters increasingly stopped developing land for domestic food production a sugar monoculture developed. West Indian planters consequently relied more and more on New Englanders for lumber and provisions. The protein found even in near-rotten refuse grades of dried cod, which could not be marketed in Europe, provided an inexpensive fuel source for growing numbers of slave laborers. ${ }^{96}$ West Indian masters could have mobilized slave labor for fishing in addition to field work, thereby reducing their dependency on imported provisions. In at least one instance, slave fishermen did produce cheap food for local field hands. However, the decision to move coerced laborers away from sugar cane was not a popular one, and planters remained content to bring in most of the food for the islands from abroad. ${ }^{97}$ New Englanders were keenly aware of this dependency.

Yankee merchants exploited the tropical markets from the beginning of settlement in the northern colonies. In 1636, Marblehead, Massachusetts, the first resident fishing station in New England, built its first vessel, the Desire, a one hundred and twenty ton ship initially employed in the local fishing industry. In 1637, she went on one of the earliest recorded New England trading voyage to the West Indies. At Providence Island, dried cod and seventeen Native

${ }^{95}$ K.G. Davies, The North Atlantic World in the Seventeenth Century (Minneapolis: University of Minnesota Press, 1974), 80; Innis, The Codfisheries, 120.

${ }^{96}$ Dunn, Sugar and Slaves, 276; McCusker and Menard, The Economy of British America, 1607-1789, 101, 155-156; and Bailyn, The New England Merchants in the Seventeenth Century, 84-85. According to McCusker and Menard, the price of land in Barbados increased by "ten times" between the 1630s and 1640s as a result of sugar production. Such real estate inflation, they argue, virtually forced smaller landholders responsible for local food production to sell their estates to sugar planters. As a result, Barbados' white population actually decreased through the seventeenth century. Ibid., 152.

${ }^{97}$ Richard Price found "several dozen references to Negro fishing slaves" in the West Indies during the colonial period. However, the use of slave fishermen to produce cheap food for field hands "is mentioned only once." For the most part, according to Price, "plantation fishing was never fully exploited." Richard Price, "Caribbean Fishing and Fishermen: A Historical Sketch,” American Anthropologist, Vol. 68, No. 6 (December, 1966), 1370. 
American captives were exchanged for a cargo of cotton, tobacco and black African slaves. The Desire returned to Boston, the commercial hub, on February 26, $1638 .{ }^{98}$ Over the next few years, Providence Island converted quickly to a slave labor system, making it one of the earliest West Indian islands to abandon servant labor. Given the impact that this conversion had throughout the region, it is significant that just as the Puritan-controlled island shifted to slaves, dried cod was forthcoming from the Puritan Commonwealth to the north. The supply of an inexpensive food source was probably critical for this labor conversion. Providence Island was not alone in this regard.

Barbados, the greatest sugar producer and slave consumer in the seventeenth century, quickly developed commercial ties to New England. Richard Vines, a Barbadian planter, wrote to John Winthrop in 1647 to inform the leader of the Puritan Commonwealth that West Indian planters were "so intent upon planting sugar that they had rather buy food at very dear rates than produce it by labor, so infinite is the profit of sugar works after once accomplished." ${ }^{99}$ Throughout the second half of the seventeenth century New Englanders built-up their own deep sea fleets to supply dried cod to these hungry West Indian markets. By 1687, 76\% of vessels clearing customs in Boston were locally registered. Salem and Boston, in particular, became centers of transatlantic shipping. Boston still took in most of the fish caught in New England shallops, and it still dominated the export trade through a mixture of its own shipping and London-owned vessels. Salem at this point had its own fleet of fishing vessels, which it outfitted

\footnotetext{
${ }^{98}$ Karen Ordahl Kupperman, Providence Island, 1640-1641: The Other Puritan Colony (Cambridge: Cambridge University Press, 1993), 172; George Francis Dow, Slave Ships and Slaving (New York: Dover Publications, Inc., 1970; first published in 1927), 267; and Roads, Jr., The History and Traditions of Marblehead, 12.

${ }^{99}$ Richard Vines to John Winthrop, July 19, 1647, Winthrop Papers, Vol. 5, (Boston: Massachusetts Historical Society, 1929), 172.
} 
along with fishing vessels from most of the New England outports, and it traded directly with the West Indies, primarily Barbados. ${ }^{100}$

The proliferation of African slave labor in the Chesapeake Bay region contributed to a lesser degree to the early expansion of the New England cod fisheries. To be sure, as early as 1619, Virginian planters were sending ships to Newfoundland to purchase dried cod, and similar ventures to New England were conducted on an irregular basis throughout the first half of the seventeenth century. ${ }^{101}$ Yet, these small scale efforts seem to have been conducted with the sole purpose of preventing English settlers from starving. The trade between New England and the Southern colonies took on new importance as Southern planters converted from a servant to a slave labor system in the second half of the century. ${ }^{102}$ It was at this point that Northern shipments of dried cod to Southern plantations took place on a regular basis. Cod was exchanged for tobacco, pork, and naval stores such as tar and turpentine. Following its own curing process, tobacco was ready for oceanic shipment around November and December each year, just in time to be sold to New England trade vessels that habitually traveled south to warmer waters in the winter months. ${ }^{103}$ This branch of New England's trade, however, was always subsidiary to the European and West Indian trades. Having said this, the trade was important enough to Southern planters that during the 1740s William Byrd II, a Virginia tobacco

${ }^{100}$ Vickers, Young Men and the Sea, 45-47.

${ }^{101}$ Edmund S. Morgan, American Slavery, American Freedom: The Ordeal of Colonial Virginia (New York: W.W. Norton \& Company, 1975), 102, 104; McFarland, A History of the New England Fisheries, 58; and Wharton, The Bounty of the Chesapeake, 22, 27.

${ }^{102}$ For more on this transition, see Morgan, American Slavery, American Freedom, 295-315.

${ }^{103}$ Hornsby, British Atlantic, American Frontier, 96-97. 
planter and slave owner, came to advocate using the British military to forcibly take control of French fishing stations in the North Atlantic. ${ }^{104}$

Mid-century New Englanders were not establishing entirely new markets for Atlantic cod among slave plantations. Rather, they were following trade patterns that had been established in the Atlantic economy at least as early as the turn of the seventeenth century. Thus, John Winthrop could write with confidence before departing England in 1629 that dried cod was “a known and staple Commodity."105 Even the Puritan divine understood which markets demanded cod, and why.

Throughout the 1600s the economic ties between New England and the West Indies multiplied. As demand for tobacco and sugar in the British Empire raised production levels in the South and in the West Indies, increased production levels stimulated slave importation. More slaves meant more demand for cheaper grades of dried cod. Heightened demand for this refuse cod generated higher production levels in New England. In order to meet these elevated production levels, more workers, salt supplies, hooks, lines, vessels, and constant maintenance from numerous waterfront artisans were necessary. In short, there was a symbiotic relationship between cod and consumer goods produced through slave labor throughout the seventeenth century and into the eighteenth century that directly influenced the expansion of New England's maritime economy. ${ }^{106}$

\footnotetext{
${ }^{104}$ Byrd justified this military conquest by stating: ““'The fishery is certainly one of the most beneficial trades that belongs to England.” Marion Tinling, ed., The Correspondence of the three William Byrds of Westover, Virginia, 1684-1776, Vol. 2, (Charlottesville: University Press of Virginia, 1977), 582.

${ }^{105}$ Winthrop Papers, Vol. 2, (Boston: Massachusetts Historical Society, 1929), 145-146.

${ }^{106}$ Vickers, "`A Knowen and Staple Commoditie'," 186-203, esp. Figure 1. For more on the ties between New England and the West Indies during the colonial period, see Andrew Jackson O'Shaughnessy, An Empire Divided: The American Revolution and the British Caribbean (Philadelphia: University of Pennsylvania Press, 2000), esp. 5877, 109-134; and Richard Pares, Yankees and Creoles: The Trade between North America and the West Indies before the American Revolution (London: Longmans, Green and Co., 1956). For more on the formative role slave labor played in bringing about the transition to capitalism, see Barbara L. Solow, "Capitalism and Slavery in the
} 
The English Civil War and the weakening position of the West Country, combined with the sugar revolution in the West Indies, contributed to the expansion of the New England cod fishing industry in the seventeenth century. Between 1641 and 1645 the annual export revenue cod brought into Massachusetts doubled from $£ 5,000$ to $£ 10,000$. In 1646, Marblehead alone drew £4,000 from its cod exports. Populations of colonial New England fishing ports grew, and between 1645 and 1675 the combined output of these fisheries expanded by 5-6\% annually, from 12,000 to 60,000 quintals per year. ${ }^{107}$

Early New Englanders typically worked along the coast between Cape Cod and the province of Maine in three-man shallops, which were open-decked, double-ended, single or double-masted vessels averaging twenty-five feet in length and six tons burden. Most of the labor force along the New England coast initially consisted of servants who were recruited in West Country ports to work for a specified amount of time under a master. ${ }^{108}$ These mobile workers were almost exclusively young men who typically left colonial fishing stations for home after their labor contract expired. ${ }^{109}$ While their British brethren were being disciplined through the use of the wage, seventeenth-century New England fishermen operated under a system of clientage, which can be understood as the maritime equivalent of the putting-out system. Due to

Exceedingly Long Run,” Journal of Interdisciplinary History, Vol. 17, No. 4 (Spring, 1987), 711-737; and Eric Williams, Capitalism \& Slavery (Chapel Hill: The University of North Carolina Press, 1944).

${ }^{107}$ Vickers, Farmers and Fishermen, 99-100. An economic analysis of early Essex County, the region with the highest concentration of fishing ports in North America in the seventeenth century, found "a $300 \%$ - 500\% increase in the size of the economy between 1640-1682." William I. Davisson, "Essex County Wealth Trends: Wealth and Economic Growth in $17^{\text {th }}$ Century Massachusetts," Essex Institute Historical Collections, Vol. 103, (Salem, MA: Newcomb \& Gauss, Co., 1967), 341.

${ }^{108}$ This was the case on a longer-lasting and more extensive scale in Newfoundland. For the ubiquitous use of servants in the seventeenth century Newfoundland fisheries, see Pope, Fish Into Wine, 63, 64, 168-175. Pope maintains that it was not until 1677 that Newfoundland's resident fishing population became comparable to the resident stations on New England's coast. Ibid., 40.

${ }^{109}$ Vickers, Farmers and Fishermen, 91-92; Heyrman, Commerce and Culture, 212-213; and Clark, The Eastern Frontier, 24. The key difference between the migratory labor force at New England and Newfoundland was that after 1631 permanent resident fishing stations had been established in the former. This settlement contributed to the earlier expansion in local labor supplies in New England. 
chronic labor scarcity in the region, workers were extended ample credit and allowed access to some productive means. Merchants contracted with vessel-owning companies of men for catches. The merchants supplied provisions and equipment, and in return the fishermen agreed to turn-over the product of their labor. ${ }^{110}$ The system of clientage changed around the turn of the eighteenth century as the New England fishing industry matured.

\subsection{THE MATURATION OF RESIDENT NEW ENGLAND FISHING STATIONS}

The second fissure in the core's economic control over the New England colonists came with the weakening of Boston's position at the turn of the eighteenth century. Boston had acted as a focal point for West Country and London interests. Capital and shipping were sent from the mother country to pick up pre-arranged loads of cod on a regular schedule. But, during the first half of the eighteenth century smaller fishing outports began eliminating middlemen altogether and marketing their catches overseas themselves. ${ }^{111}$ In 1744 Boston selectmen bemoaned the fact in town meetings. They complained that "both Fish and Supply is Confined to the Fishing towns who generally Send it abroad in their own Vessels, Especially Marblehead, Salem, and Plymouth, which has rendered them much Abler and Us much less to Support Our Usual proportion of the Province Tax.” Ten years later, Bostonians further lamented the fact that "the very men in Boston who heretofore supply'd the Fishery and Traders at Marblehead and

${ }^{110}$ Vickers, Farmers and Fishermen, 103, 108-116, 121n, 122-123, 153; Vickers, Young Men and the Sea, 15, 35. The West Country merchants responsible for financing these colonial operations had organized the cloth industry through the putting-out system since the mid-fifteenth century. Hornsby, British Atlantic, American Frontier, 10. Also, merchants in Bristol got involved in the fishing industry once the cloth trade moved decisively to London in the fifteenth century. Sacks, The Widening Gate, 34-35. It is therefore possible that the medieval West Country cloth industry provided an early business model for the colonial fisheries.

${ }^{111}$ Vickers, Young Men and the Sea, 70-71; and Heyrman, Commerce and Culture, 330-365. 
elsewhere, now buy great part of their Supply of English goods from those, to whom, but a very few Years since they used to Furnish all the English or European Goods those persons had.”112 Robert Hooper and Jeremiah Lee, two of the wealthiest fish exporters in Marblehead, informed Lieutenant Governor Thomas Hutchinson in 1764: "We are not only largely concerned in the owning of Vessels, \& employing the People in the Fishery, but annually ship large Quantities both to Europe and the West Indies on our own Accounts." ${ }^{113}$ The expansion of commercial fishing ports such as Marblehead adversely affected Salem, in addition to Boston. Salem's fishing fleet declined from 60 vessels in 1689 to 30 in $1765 .{ }^{114}$ The expansion of smaller fishing ports hurt Salem's position as a market town and outfitter for colonial fishing operations. ${ }^{115}$

While economic control over the fisheries fanned out from Boston and Salem during the eighteenth century, it did not stray too far from these traditional commercial centers. Much of the labor and capital involved in the New England fisheries was concentrated in the North Shore coastal communities of Essex County, Massachusetts, including Marblehead, Gloucester, Beverly and Ipswich. ${ }^{116}$ These ports became commercial centers for the production of dried cod for shipment to overseas markets.

Marblehead expanded at this time to become the foremost fishing port in colonial New England, and its own outfitter. By 1750, it surpassed its neighbor Salem in terms of the size of

${ }^{112}$ Phillip Chadwick Foster Smith, ed., The Journals of Ashley Bowen (1728-1813), Vol.1, (Portland, Maine: The Colonial Society of Massachusetts, 1973), 138-139.

${ }^{113}$ Hooper Fisheries Statement, 10 January 1764, MHS, Misc. Bd. Manuscripts, 1761-1765.

${ }^{114}$ For the 1689 figure, see Vickers, Farmers and Fishermen, 146. For the 1765 statistic, see Thomas Jefferson, Secretary of State, Report on the State of the Cod Fisheries, 1791, American State Papers: Commerce and Navigation, I:13, Table 2.

${ }_{115}$ Vickers, Young Men and the Sea, 70-71.

${ }^{116}$ Due to sparse settlement, New Hampshire and Maine remained politically subordinate to Massachusetts until 1679 and 1820, respectively. Indeed, despite its early independent legal status, Parliament did not consider New Hampshire worthy of a separate royal governor until 1741. Although commercial cod fishing played an important role in settlement in these regions, and remained a subsidiary sector of these provincial economies, the lumber and shipbuilding industry dominated economic affairs around the Piscataqua River between colonial New Hampshire and Maine. Portsmouth controlled the pine mast trade until the 1720s, when Falmouth (Portland) developed into a commercial port. Clark, The Eastern Frontier, 54-58, 64-65, 97-102, 115-116. 
its fishing fleet, the number of its fishermen, and the amount of fish caught on an annual basis. ${ }^{117}$ At this time, Marbleheaders maintained 150 fishing vessels amounting to 1/3 the total tonnage of the entire Massachusetts fleet, and caught 50\% of the fish exported from Massachusetts to Spain. ${ }^{118}$ The same Reverend John Barnard who in 1714 had referred to Marbleheaders as "slaves” recorded in mid-century that his adopted hometown had its own fleet of "between thirty and forty ships, brigs, snows, and topsail schooners engaged in foreign trade.”119 Dr. Alexander Hamilton, a Scottish émigré who visited Marblehead in 1744, wrote "they deal for 34,000 Pounds sterling prime cost value in fish yearly, bringing in 30,000 quintals, - a quintal being one hundred-weight dried fish, which is 3,000,000 pounds' weight, a great quantity of that commodity.”120 During the 1720s, Gloucester returned to fishing after more than forty years of attention to farming, sending out from Cape Anne 49 vessels and 245 fishermen. By 1741, the number of vessels had increased to 70, and by 1775 the port boasted 150 vessels and 900 fishermen. This sudden and extensive growth made Gloucester the fastest growing fishing port in New England. ${ }^{121}$ Ipswich, located northwest of Gloucester, also expanded quickly, but could not sustain the growth. In the early 1720s the town had 29 vessels and 149 fishermen, but only 14 vessels were added over the next fifty years. Beverly, northeast of Salem, launched its fishing fleet around mid-century. In 1762, there were only 9 fishing vessels in the port, but by 1775 Beverly’s fleet numbered 35 and employed 300 fishermen. ${ }^{122}$

\footnotetext{
${ }^{117}$ Vickers, Young Men and the Sea, 71; Vickers, Farmers and Fishermen, 100, 152; Heyrman, Commerce and Culture, 330-332, 343; and McFarland, A History of the New England Fisheries, 96.

${ }^{118}$ Vickers, Young Men and the Sea, 70; and Heyrman, Commerce and Culture, 331.

119 John Barnard, “Autobiography of the Reverend John Barnard,” Collections of the Massachusetts Historical Society, $3^{\text {rd }}$ ser., Vol. 5 (Boston: Little, Brown, and Company, 1836), 240.

${ }^{120}$ Carl Bridenbaugh, ed., Gentleman's Progress, The Itinerarium of Dr. Alexander Hamilton (Chapel Hill, N.C.: University of North Carolina Press, 1948), 5.

${ }_{121}$ Vickers, Farmers and Fishermen, 192; Heyrman, Commerce and Culture, 149-154.

${ }^{122}$ Vickers, Farmers and Fishermen, 193.
} 
Commercial fishing expanded in these small-scale eighteenth century fishing stations for several reasons. British victories in various colonial wars stimulated the New England fishing industry. The Treaty of Utrecht ended eleven years of war between France and Great Britain that had stunted the growth of the New England fishing industry. French warships and privateers had scoured the New England coast, slowing the traffic in cod considerably. The treaty restricted French cod fisheries in the North Atlantic, thereby opening commercial possibilities to British interests, particularly in supplying the French West Indian islands with dried cod. Likewise, English wars with France and Spain between 1743 and 1763 set back the colonial fishing industry. Yet the treaty signed at the end of the Seven Years' War, in 1763, transferred most of French Canada, including Newfoundland, into British hands. ${ }^{123}$ Taken as a whole, the eighteenth century colonial wars destroyed France's position in the North Atlantic fishing industry and gave Great Britain a virtual monopoly over the cod trade. ${ }^{124}$ The exclusion of French warships and most of their fishermen expanded New England's access to North Atlantic cod. Brook Watson, an eyewitness called before the House of Commons in 1775 to testify on behalf of the North American merchants regarding Parliament's recent passage of the Fisheries Bill that closed the New England cod fisheries, gave his opinion on the positive effect of the 1763 treaty on the cod trade to the West Indies. He testified:

That the most inferior fish is exported to the neutral or French islands, and exchanged for molasses on VERY ADVANTAGEOUS TERMS, as the French are PROHIBITED from fishing. These molasses are sent to New-England, and manufactured into rum, which is sold for about fourteen pence per gallon, and used in the fisheries of New England and Newfoundland, and also exported to

\footnotetext{
${ }^{123}$ The French retained St. Pierre and Miquelon, and rights to fishing on Newfoundland's western shore. For copies of this peace treaty, see The Providence Gazette; And Country Journal, May 21, 1763; The Newport Mercury, May 23, 1763; and The New-Hampshire Gazette, May 27, 1763.

${ }^{124}$ Innis, The Codfisheries, 138, 160-161, 171, 179-180; and McFarland, A History of the New England Fisheries, 78-81, 94-101.
} 
Guinea, and there exchanged for slaves, many of whom are sold to the French, and therefore eat the fish procured by the NEW ENGLANDERS. ${ }^{125}$

To be sure, the French continued to work North Atlantic waters, as the exclusionary articles in the peace treaties proved difficult to enforce. However, the British Navy forcibly removed French settlers and arrested French fishermen who violated these articles. By the end of the Seven Years’ War, New Englanders enjoyed greater access to cod and additional markets for this commodity as a result of wars and peace terms.

Expansion of the fishing industry did not automatically occur as quickly as the ink dried on these treaties, however. Merchants in provincial fishing stations had to be convinced doing more in the Atlantic trade themselves was worth the additional efforts and financial risk. In the case of Marblehead, Reverend John Bernard, a fixture in the community from 1715 to 1770 , became an outspoken advocate for locally-operated overseas trade. Barnard utilized his ecclesiastical position as pastor of Marblehead's First Congregational church to bring about economic changes in the fishing industry. First, he traveled to Boston Harbor in order to meet with "English masters of vessels." Barnard educated himself on the finer points of transatlantic commerce - in his own words, "that I might by them be let into the mystery of the fish trade." After a time, Barnard felt that he had gained "a pretty thorough understanding” of what it meant to establish European connections, broker deals, and transport goods directly to a buyer instead of relying on a colonial middleman. "When I saw the advantages of it," Barnard wrote of transatlantic trade, "I thought it my duty to stir up my people, such as I thought would hearken to me, and were capable of practicing upon the advice, to send the fish to market themselves, that they might reap the benefit of it, to the enriching themselves, and serving the town.” Once

${ }^{125}$ The Massachusetts Spy: Or, American Oracle of Liberty, May 3, 1775. 
Barnard had acquired "a pretty thorough understanding of the business," the parson began disseminating his ideas about local economic development, especially among the younger men of his congregation. ${ }^{126}$

Joseph Swett, Jr., for example, had been a merchant and a member of First Church. Barnard described him as "a young man of strict justice, great industry, enterprising genius, quick apprehension and firm resolution, but of small fortune.” The pastor of First Church took the young Swett under his wing and informed him of a plan to establish transatlantic business connections in order to send their own fish to market, eliminating the middlemen in Salem and Boston. "To [Swett] I opened myself fully," Barnard wrote, "laid the scheme clearly before him, and he hearkened unto me, and was wise enough to put it in practice." Soon, Swett fitted out a small schooner, hired a captain, and "sent a small cargo [of fish] to Barbados." The venture proved so successful that Swett was able to fit out several trading vessels for additional voyages to Spain. In Barnard's words, Swett "soon found he increased his stock, built vessels, and sent fish to Europe, and prospered in the trade, to the enriching of himself; and some of his family, by carrying on the trade, have arrived at large estates." ${ }^{\text {127 }}$ Eventually, Swett brokered several deals with ports in Spain, and a triangular trade was established in which fish from Marblehead was traded for lemons and raisins in Spain, which were traded for rum in the West Indies, which was then sold throughout Massachusetts. ${ }^{128}$ According to Barnard, "the more promising young men of the town soon followed [Swett's] example.” The result of the pastor's effort was that in 1766, Marblehead had "between thirty and forty ships, brigs, snows, and topsail schooners engaged in

\footnotetext{
${ }^{126}$ Barnard, “Autobiography of the Reverend John Barnard,” 239-40.

${ }^{127}$ Ibid.

${ }^{128}$ Roads, Jr., The History and Traditions of Marblehead, 46-47.
} 
foreign trade." ${ }^{\prime 29}$ In short, while tobacco planters in the Chesapeake region continued to rely on British bottoms to freight their staple to European markets, New England fish merchants were becoming self-sufficient. ${ }^{130}$

Local population booms in the eighteenth century also stimulated economic expansion in the fishing industry by contributing to increased productivity. Between 1650 and 1725, fishing ports in Essex County, Massachusetts realized a ten-fold increase in population. ${ }^{131}$ By comparison, the total population in New England grew from 22,900 in 1650 to 170,900 in 1720, realizing a 7.7-fold increase. ${ }^{132}$ Salem, Beverly, Manchester, and Gloucester grew from a combined population of 3,500 in 1690 to 16,000 in $1765 .{ }^{133}$ Within this county-wide expansion, Marblehead grew fastest. Some 1,200 people lived there in 1700, one-third the number in nearby Salem. As early as 1720 , the two ports housed 2,000 people apiece. ${ }^{134}$ By 1744 , one observer estimated that 5,000 people lived and worked in Marblehead. ${ }^{135}$ By comparison, Boston's population expanded from 6,000 in 1690 to 17,000 in $1740 .^{136}$ Expanding employment opportunities in the fisheries may explain some of the faster rate of population increase in Essex County as compared to greater New England. Fishing servants continued to abandon the migratory fisheries at Newfoundland, and through sundry means they filed into New England maritime communities. ${ }^{137}$ However, in 1715 two-thirds of Essex County's labor force was

\footnotetext{
${ }^{129}$ Barnard, “Autobiography of the Reverend John Barnard,” 240.

${ }^{130}$ For the tobacco planters' reliance on British shipping well into the eighteenth century, see Price, Tobacco in Atlantic Trade.

${ }^{131}$ Vickers, Farmers and Fishermen, 156.

${ }^{132}$ McCusker and Menard, The Economy of British America, 1607-1789, 103, Table 5.1.

${ }^{133}$ Vickers, Farmers and Fishermen, 211.

${ }^{134}$ Heyrman, Commerce and Culture, 245.

${ }^{135}$ Bridenbaugh, ed., Gentleman's Progress, The Itinerarium of Dr. Alexander Hamilton, 5.

${ }^{136}$ Gary B. Nash, The Urban Crucible: Social Change, Political Consciousness, and the Origins of the American Revolution (Cambridge: Harvard University Press, 1979), 54-55.

${ }^{137}$ Pope, Fish Into Wine, 241-248; and Handcock, Soe longe as there comes noe women, 27-30.
} 
generated by local families and by 1750 that proportion reached three-quarters. ${ }^{138}$ Whereas Newfoundland did not realize a demographically self-sufficient labor force until the 1790s, Massachusetts did so in the first quarter of the century. ${ }^{139}$ Migration into Marblehead tapered off through the 1730s and 1740s, and by 1750, $80 \%$ of Marblehead's adult males were born into families that had lived in the town for at least thirty years. ${ }^{140}$ Between 1760 and 1774 , 89\% of all fishermen sailing out of Marblehead were born in that port. In Gloucester and Beverly, the corresponding percentages were $73 \%$ and $85 \%$, respectively. ${ }^{141}$ Natural increase, then, more than employment-driven immigration, explains the demographic expansion in eighteenth century Essex County.

More workers, ready at hand, enabled New England fishing ports to send larger fleets to sea and to catch and process greater quantities of cod. In 1675, 1,320 New Englanders in 440 vessels of 2,640 tons caught 60,000 quintals of cod. One hundred years later, an estimated 4,405 New Englanders in 3,000 vessels of 25,630 tons caught 350,000 quintals. ${ }^{142}$ By 1768, dried cod

${ }^{138}$ Vickers, Farmers and Fishermen, 155-157.

${ }^{139}$ Handcock, Soe longe as there comes noe women, 73-90, 91, esp. Figure 4.1. Another contrast between the two centers of cod fishing was the fact that the Massachusetts labor force was almost exclusively male. Vickers, Farmers and Fishermen, 175. More comparative work needs to be done to get at the reasons for these gender disparities.

${ }^{140}$ Heyrman, Commerce and Culture, 336.

${ }^{141}$ Vickers, Farmers and Fishermen, 157n.

${ }^{142}$ Vickers, Farmers and Fishermen, 100, 154, esp. Table 4. By comparison, Newfoundland cod fishing interests extracted 600,000 quintals in 1770 . Roughly an equal percentage of this catch was brought in by the West Country migratory sector of the Newfoundland fisheries and the permanent inhabitants living on the land of cod. Handcock, Soe longe as there comes noe women, 75-76, Figure 4.1. Thus, on the eve of the Revolutionary War the New England resident fishing stations were slightly out-producing both of the Newfoundland cod fishing interests. The two Newfoundland interests are conflated in Hornsby's assessment that "the Newfoundland fishery remained the most significant producer" of dried cod in eighteenth century British North America. Hornsby, British Atlantic, American Frontier, 28, emphasis my own. The value of the eighteenth century New England fisheries may have been hidden from contemporary Parliamentarians, who similarly tended to view the Newfoundland fisheries as a single productive unit. 
was the most valuable export commodity in all of New England, bringing in £152,155 every year, or $35 \%$ of the total export revenue for the entire region. ${ }^{143}$

New England merchants shipped cod all over the Atlantic world in the eighteenth century, but the greatest emphasis was placed on trade with the West Indies. The amount of cod shipped overseas fluctuated in rhythm with cod stock levels and the effectiveness of the curing process each year, making it difficult to determine exactly what percentage of New England dried cod was shipped to certain destinations over an extended period of time. At the end of the seventeenth century it was estimated that $75 \%$ of New England's dried cod was exported to Portugal, Spain, and the Atlantic Wine Islands. ${ }^{144}$ Based on the $1752-53$ customs records for Salem, only $26.4 \%$ of the 121 vessels from Salem, Gloucester and Marblehead cleared for Southern Europe and the Wine Islands in the year prior to the outbreak of the Seven Years' War that disrupted trade in the region. The remaining $73.6 \%$ cleared for the Southern Colonies and the West Indies. An overwhelming majority of the vessels from Salem and Gloucester cleared for the West Indies, while Marblehead sent roughly the same number to both destinations. ${ }^{145}$ In

${ }^{143}$ McCusker and Menard, The Economy of British America, 1607-1789, 108, Table 5.2. By comparison, settlers in Atlantic Canada (Quebec, Nova Scotia, and Newfoundland) exported fish, their leading commodity, worth $£ 133,932$ in 1768 , or $73 \%$ of the total export revenue for the region. Ibid., 115, Table 5.4. At the same time, Middle Colonies (New York and Pennsylvania) exported grains worth £379,380, or 72\% of the total export revenue. Ibid., 199, Table 9.3. The Upper South (Maryland and Virginia) exported tobacco worth £756,128, or 72\%. Ibid., 130, Table 6.1. The Lower South (North Carolina, South Carolina, and Georgia) exported rice worth £305,533, or 55\%. Ibid., 174, Table 8.2. The West Indies exported muscovado sugar worth £2,762,250, or 71\%. Ibid., 160, Table 7.3. Colonial New England maintained a smaller, more diversified economy than most of the other regions. Yet, even in this diversified sector, fish brought in 15\% more annual revenue than its nearest competitor, livestock.

In 1793, despite the declension of the fisheries that resulted from the American Revolutionary War and the complete prohibition against the importation of American salted fish anywhere in the British Empire, our foremost trading partner at the time, dried cod was the fifth leading export in the entire United States (behind breadstuffs, tobacco, rice, and wood, in that order). The industry had rebounded from the disruption of the Revolutionary War somewhat by the 1790s, and trade with France, Spain, and Portugal remained lucrative, although there was an import tax on American salted fish in place in France. See, Thomas Jefferson, Secretary of State, "Report on the Privileges and Restrictions on the Commerce of the United States in Foreign Countries,” December 16, 1793, American State Papers: Foreign Relations, I:300-301.

144 See footnote \#85 above.

${ }^{145}$ Heyrman, Commerce and Culture, 332n. According to David Hancock, the foremost authority on the role Madeira wine played in the Atlantic economy, Massachusetts was only able to control 25\% of the market for dried 
1763, as news of international peace spread around the Atlantic world, Edward Payne, a Boston merchant and member of the Society for the Encouragement of Trade and Commerce, estimated that $60 \%$ of New England's annual catch was being shipped to sugar plantations in the Caribbean. ${ }^{146}$ One year later, Robert Hooper and Jeremiah Lee, two of the wealthiest fish exporters in Marblehead, informed Lieutenant Governor Thomas Hutchinson "the fish caught in the several fishing Towns in the Province of the Massachusetts Bay is annually from 220 to 240 Thousand Quintals, about 2/5 whereof is made merchantable \& shipped to Spain, Portugal, \& Italy; the other 3/5 is shipped for the West Indies, not being fit for the European Markets.”147 The figure of 3/5 was later corroborated by "Mr. Kelly," who "lived in New York and was bred a merchant;" and two merchants whose "knowledge is principally confined to New England, Nova Scotia and Newfoundland: "Mr. Wentworth," and "Brook Watson.” Each of these men testified before Parliament in 1766 regarding the impact of Parliamentary acts on colonial trade. ${ }^{148}$ In his capacity as Secretary of State under President George Washington, Thomas Jefferson retrospectively calculated a rough balance of trade to the West Indies and Southern Europe between 1765-75. In Jefferson's report, 50.9\% of New England's dried cod was being exported to Europe, which in this case refers specifically the ports in Iberia and among the Wine Islands, while $49.1 \%$ of the cod was exported to the West Indies. ${ }^{149}$ However, there is reason to suspect that Jefferson may have overestimated the trade to Europe, given Salem's customs records,

cod in Madeira at any time. Moreover, between 1755 and 1774, the amount of dried cod cleared out of Salem and Boston for Madeira declined from 163,000 quintals to 122,000 quintals per year. David Hancock, "Markets, Merchants, and the Wider World of Boston Wine, 1700-1775," in Conrad Edick Wright and Katheryn P. Viens, eds., Entrepreneurs: The Boston Business Community, 1700-1850 (Boston: Northeastern University Press, 1997), 85.

${ }^{146}$ Testimony of Edward Payne of Boston, Merchant, dated Boston, December, 1763, Ezekiel Price Papers, 1754-1785, MHS.

${ }^{147}$ Hooper Fisheries Statement, 10 January 1764, MHS, Misc. Bd. Manuscripts, 1761-1765.

${ }^{148}$ PDBP, Vol. 2, 359-365, 571-572.

${ }^{149}$ Thomas Jefferson, Secretary of State, "Report on the State of the Cod Fisheries, 1791,” American State Papers: Commerce and Navigation, I:13. 
Hooper and Lee's report, and the Parliamentary testimonies of three additional merchants. Taken together, the trade data indicates eighteenth century New Englander's placed a greater emphasis on shipping dried cod to slave plantations in the West Indies than they did during the seventeenth century. ${ }^{150}$ On average, $60.7 \%$ of the cod processed on Yankee flakeyards was shipped to the West Indies between 1752-1775. Between 1771-73, New England fish merchants controlled $81.7 \%$ of the West Indian market. ${ }^{151}$ Other New England commodities followed this trade pattern. From 1768 to 1772, Yankee merchants shipped 79\% of their grain and flour, 88\% of their lumber, and 99\% of their cattle and horses to the West Indies. In all, $63.5 \%$ of New England's exports went to the West Indies during this time period. ${ }^{152}$ Indeed, such was the commercial connection between Massachusetts and the West Indies that the region southwest of Boston became known as "Jamaica Plain," and a body of water there was called "Jamaica Pond.”153

A substantial New England sack trade had even emerged by the mid-eighteenth century that further tied Yankee traders to West Indian markets. Instead of taking the trouble and expense to fish and cure the catch themselves, an unspecified number of New England merchants sent trade ships with their own manufactured rum, together with West Indian sugar, molasses, and rum, to exchange with fishermen around Newfoundland for refuse grade dried cod. These

\footnotetext{
150 The evidence in this paragraph largely contradicts modern scholarly interpretations. James G. Lydon estimates "the West Indies and southern Europe were of nearly equal importance as market areas" in the eighteenth century. James G. Lydon, "Fish for Gold: The Massachusetts Fish Trade with Iberia, 1700-1773,” The New England Quarterly, Vol.54, No.4 (December, 1981), 539. Also, see Innis, The Codfisheries, 162.

${ }^{151}$ Selwyn H.H. Carrington, The British West Indies During the American Revolution (Providence, RI: Foris Publications, 1988), 44, Table 30. I arrived at the figure of $81.7 \%$ by first adding the barrels, quintals, and kegs of fish imported into the West Indies between 1771-73 from America, Nova Scotia and Canada, and Newfoundland. I then divided the sub-total for America by the total. Here, I assume that "America" refers to the New England cod fisheries. In 1771 alone, New England fish merchants shipped 91.9\% of all fish exported from British North America to the "British \& Foreign West Indies." "Exports to the British \& Foreign West Indies between the $5^{\text {th }}$ day of January 1771 \& the $5^{\text {th }}$ day of January 1772," British North American Customs Papers, 1765-1774, MHS.

${ }^{152}$ Hornsby, British Atlantic, American Frontier, 135-136, Figure 4.6.

153 "Plan of Boston and vicinity, 1775," NDAR, Vol. 1, 197.
} 
New England merchants then traded the refuse for more sugar and molasses in the West Indies. ${ }^{154}$ The value of the "West-India Cod-Fish," or the refuse grade dried cod, involved in this sack trade was estimated at $£ 10,000$ in $1764 .{ }^{155}$

The trend toward greater commercial ties between New England fish merchants and West Indian markets during the eighteenth-century was primarily the result of four factors: the nature of the curing technique used by New Englanders; the proliferation of distilleries in New England; increased West Indian slave populations; and Newfoundland's domination of the Southern European markets. Prior to the development of an off-shore banks fishery, New England fishermen caught fish and headed for land as fast as possible, where they dressed, salted, and spread cod on fish flakes for drying. ${ }^{156}$ This process usually resulted in high yields of merchantable grade dried cod capable of being marketed in Europe. Because of the distance involved, banks fishing required a different curing process. New Englanders began utilizing the combination cure first developed by the Dutch in the late fourteenth century. ${ }^{157}$ Schooners would travel several days to offshore banks, take in cod, and fishermen would salt the catch wet, right out of the ocean. The lightly salted cod would then be stacked in the holds of the schooner for a prolonged time. Later, the crew would return to their home port, where shoremen would air-dry the damp, salty catch. ${ }^{158}$ Invariably, the combination of a wet-salt cure and an air-dry

${ }^{154}$ Boston Evening Post, January 20, 1766.

155 "A Calculation of the State of the Cod and Whale Fisheries, belonging to the Province of the MassachusettsBay, the Year past.” New London Gazette, February 2, 1764.

${ }^{156}$ Vickers, Farmers and Fishermen, 149.

${ }^{157}$ See footnote \#22 above.

${ }^{158}$ Pope, Fish Into Wine, 27; and Vickers, Farmers and Fishermen, 150. Vickers refers to the combination cure as "a new cure." Ibid., 149. However, Pope notes that "similar processes had long been in use on the other side of the Atlantic." Ibid. For the employment of the combination cure among eighteenth century English settlers in Newfoundland, see Head, Eighteenth Century Newfoundland, 72-73. Head suggests that British fishermen learned the cure from French fishermen in the Newfoundland region. The combination cure was not dominant in Newfoundland in the eighteenth century, which partly accounts for the predominance of Newfoundland cod in European markets. 
cure produced a greater percentage of refuse grade dried cod, defined by Edward Payne, a Boston fish merchant, as "that being only such as is over Salted, Sun Burned, and broken, \& thereby rendered unfit for any Market in Europe.”159 One New England fish merchant testified before Parliament in 1766 that colonial fishermen worked "at a great distance from the shore” and their catch was "kept in ships where it grows soft and becomes therefore soft and refuse.”"160 In short, the use of the schooners to work off shore banks and the employment of the combination cure produced a grade of dried cod that could only be sold to slave plantations. In Payne’s words, “as we can’t cure Fish for the European Market separate from the other sort sent to the W. Indies, \& as we have no other Market for what is made by the Bankers [i.e. the refuse grade dried cod], it will be lost if not sent to the foreign Islands in the W. Indies.” It was Payne's considered opinion that without West Indian markets, and the slave populations therein, "the whole Bank Fishery” would have been “destroy[ed].”161

The proliferation of New England distilleries in the eighteenth century provided additional stimulus for the eighteenth century shift in Atlantic trade patterns. There were a handful of distilleries in operation throughout New England at the turn of the eighteenth century. By 1770 there were 140 rum distilleries in the thirteen North American colonies, 97 of which were located in New England. At this time, colonists imported over 6.5 million gallons of molasses from the West Indies. Lumber and dried cod were the two primary commodities New Englanders exchanged for the enormous quantity of molasses they needed to feed their

159 "In the Preamble to a late Act of Parliament," 1764, attributed to Edward Payne, Ezekiel Price Papers, 17541785, MHS.

${ }^{160}$ PDBP, Vol. 2, 364. MHS.

161 "State of the Trade \& Observations on the Late Revenue Acts," 1767, Ezekiel Price Papers, 1754-1785, 
expanding distilleries, which could not be gotten from Iberia or the Wine Islands. ${ }^{162}$ Rum production in New England increased throughout the eighteenth century as supplies of West Indian molasses expanded. Greater sugar production in the West Indies was made possible by the use of greater numbers of slave laborers.

The plantation complexes in the West Indian islands imported huge numbers of black African slaves throughout the eighteenth-century, which generated greater demand in that region for shipments of dried cod from New England. Jamaica became the largest slave society in the British West Indies, expanding its slave population twenty-five times over between 1673 and 1774. ${ }^{163}$ In 1700, there were 115,000 slaves in the British West Indian islands, and 54,000 in the French islands. Forty years later, these numbers expanded to 250,000 and 228,000, respectively. By 1770, there were 434,000 slaves living, working, and dying on the British islands, and 393,000 in the French islands. ${ }^{164}$ In short, British planters had to feed 319,000 more mouths in 1770 than they did at the beginning of the century, while French planters had 339,000 more.

Feeding these slaves well, and providing for their living conditions in general, were not issues plantation managers and owners spent a great deal of time worrying about in the West Indies. To be sure, black slaves did not live or eat as well as their white masters. Yet, slaves were consumers of food. They produced some of the protein for their dietary needs. In part, slaves planted and grew their own vegetables in gardens and on the edges of cultivated sugar

${ }^{162}$ McCusker and Menard, The Economy of British America, 1607-1789, 290-291, esp. Figure 13.1; William B. Weeden, Economic and Social History of New England, 1620-1789, Vol. 2, (New York: Hillary House Publishers, Ltd., 1963), 502, 641; and Pares, Yankees and Creoles, 31-33.

${ }_{163}$ O'Shaughnessy, An Empire Divided, 8, 27.

${ }^{164}$ Stanley L. Engerman, "Economic growth of colonial North America," in McCusker and Morgan, eds., The Early Modern Atlantic Economy, 236, Table 9.1A. The table lists only "black" populations. Here, it is assumed a majority of this West Indian black population were slaves. According to O'Shaughnessy, "free people of color represented less than 2 percent of the total population of the islands" during the mid-to-late eighteenth century. O'Shaughnessy, An Empire Divided, 29. For more on the expansion of the French West Indian islands, see Eccles, The French in North America, 1500-1783, esp. ch. 6, “The Slave Colonies, 1683-1748;” and Blackburn, The Making of New World Slavery, 277-306, 431-456. 
plantations. A few raised poultry instead of planting food. Slaves were also given fishing hooks to help supplement their diets, and they became proficient fishermen. Yet, such cost-saving measures were not enough to make these coerced laborers self-sufficient. Slave provision grounds tended to be small, most of the fresh fish that was caught supplied master's tables, and hurricanes frequently devastated food crops on the islands. As a result, the majority of West Indian slave diets comprised imported provisions. Some salted beef was brought in from Ireland, although most of it went to fuel the remaining white indentured servant populations on the islands. Fish merchants in England, Scotland, and in the Netherlands shipped dried and pickled herring to the West Indies, and a portion went to the slaves. Flour, corn, and beans were imported from North America. And dried, salted refuse grade cod from New England remained an inexpensive source of protein with which to fuel slave labor. ${ }^{165}$ On average, individual slaves on the British islands consumed thirty pounds of fish each on an annual basis during the second

\footnotetext{
${ }^{165}$ Sherry Johnson, "El Niño, Environmental Crisis, and the Emergence of Alternative Markets in the Hispanic Caribbean, 1760s-70s," William and Mary Quarterly, $3^{\text {rd }}$ Series, Vol. LXII, No. 3 (July, 2005), 365-410; J.R. Ward, British West Indian Slavery, 1750-1834 (Oxford: Clarendon Press, 1988), 19-24; R.C. Nash, "Irish Atlantic Trade in the Seventeenth and Eighteenth Centuries," The William and Mary Quarterly, $3^{\text {rd }}$ Series, Vol. 42, No. 3 (July, 1985), 334-336; Richard N. Bean, "Food Imports into the British West Indies: 1680-1845,” in Vera Rubin and Arthur Tuden, eds., Comparative Perspectives on Slavery in New World Plantation Societies (New York: New York Academy of Sciences, 1977), 581-590; Carrington, The British West Indies During the American Revolution, 53-56, 110-114; Richard B. Sheridan, "The Crisis of Slave Subsistence in the British West Indies during and after the American Revolution,” William and Mary Quarterly, $3^{\text {rd }}$ Series, Vol. 33, No. 4 (October, 1976), 620-621; Pares, Yankees and Creoles, 24-27; Richard Price, "Caribbean Fishing and Fishermen: A Historical Sketch," American Anthropologist, Vol. 68, No. 6 (December, 1966), 1363-1383, esp. 1370; Eccles, The French in North America, 1500-1783, 90, 193-194; and Innis, The Codfisheries, 162-163. Blackburn maintains that the French islands were less dependent on imported provisions than the British islands. Blackburn, The Making of New World Slavery, 438439. O'Shaughnessy argues that Barbados and the British Leeward Islands were more dependent on external food supplies than Jamaica and the British Windward Islands. O'Shaughnessy, An Empire Divided, 70-72. For more on the importance of slave provision-grounds to Jamaica's domestic economy, see Beth Fowkes Tobin, " "And there raise yams': Slaves' Gardens in the Writings of West Indian Plantocrats," Eighteenth-Century Life, Vol. 23, No. 2 (May, 1999), 164-176; Sydney W. Mintz and Douglas Hall, "The Origins of the Jamaican Internal Marketing System," in Hilary Beckles and Verene Sheperd, eds., Caribbean Slave Society and Economy (New York: New Press, 1991), 319-334; Orlando Patterson, The Sociology of Slavery: An Analysis of the Origins, Development and Structure of Negro Slave Society in Jamaica (London: MacGibbon \& Kee, 1967), 216-230; and John H. Parry, "Plantation and Provision Ground: An Historical Sketch of the Introduction of Food Crops into Jamaica," Revista de historia de America, Vol. 39 (1955), 1-20. More comparative work needs to be done to determine the exact extent to which British and French islands depended on supplies of New England dried cod. New England fish merchants certainly exchanged dried cod in both British and French markets throughout the eighteenth century.
} 
half of the eighteenth century. This figure varied depending on the availability of provisions and the plantation involved. Slaves could each be given as little as twelve pounds of fish per year or as much as seventy pounds. The most common daily allowance for a slave at this time was one pint of corn and one-seventh of a pound of fish. ${ }^{166}$

New England maritime commercial expansions was further stimulated by the fact that warfare and peace negotiations had gone a long way toward establishing Great Britain's hegemony around Newfoundland. British cod production increased exponentially throughout the eighteenth century as a result, which motivated New Englanders to concentrate their efforts on the West Indies. In 1710, the British cod fishing interests at Newfoundland, understood as both the resident fishery and the West Country migratory fisheries, produced 100,000 quintals. Production then increased to over 300,000 quintals in 1730; over 400,000 quintals in 1750; over 600,000 quintals in 1770; and over 700,000 quintals in $1790 .{ }^{167}$ Much of this Newfoundland cod went to ports in Iberia and the Wine Islands. During the eighteenth century, the English West Country migratory fishermen and Newfoundland planters consistently produced a majority of the British cod exported to Spain, Portugal, the Madeiras, Azores, and Canaries. Assuming the Newfoundland interests and the New England fisheries accounted for the total annual British cod production, the Newfoundland interests controlled an average of 78.6\% of all Southern European markets throughout the entire eighteenth century. ${ }^{168}$ By contrast, these same Newfoundland

\footnotetext{
${ }^{166}$ Ward, British West Indian Slavery, 20-21, 105-107, esp. Table 7. I am grateful to Ken Morgan for bringing this reference to my attention.

${ }^{167}$ Handcock, Soe longe as there comes noe women, 76, Figure 4.1. Following a dip during the Napoleonic Wars, Newfoundland production topped 800,000 quintals. Again, it should be noted that such things as wars and weather patterns caused production rates to fluctuate. At no time did cod production continue at an unbroken advance.

${ }^{168}$ Lydon, "Fish for Gold," 544-545, Table 2. Steele has pointed out that as early as 1698, 64\% of the West Country fishing fleet $(\mathrm{N}=135 / 210)$ traveled to ports in Spain and Portugal before returning to England. Steele, English Atlantic, 84. Portugal and Spain remained the largest consumers of "English cod" from Newfoundland well into the twentieth century. Álvaro Garrido, "Political Economy and International Trade: The Portuguese Market for
} 
interests controlled only $13.5 \%$ of the West Indian markets between $1771-73 .{ }^{169}$ The proximity of Newfoundland and West Country merchants gave them an edge over New Englanders in terms of getting their fish to market. And whenever the Newfoundland interests glutted the European markets, such as they did during the 1720s and early 1770s, these markets lost their comparative price advantage over the markets in the West Indies. A combination of Newfoundland's control, the New Englander's choice of curing techniques, the proliferation of distilleries, and the expansion of the slave plantations explains why the principal economic function of the New England cod fisheries in the Atlantic economy involved provisioning the expanding number of Southern and, more especially, West Indian slave plantations in the eighteenth century.

Cod's role in the Atlantic economy was not created with the expansion of distilleries and plantations. Certain essential continuities over several centuries existed in the Atlantic cod fishing industry. A traditional curing process was still used and dried cod was still shipped to Southern European Catholics and slaves on sugar plantations, just as it had been in the Middle Ages. But North Atlantic cod fishing had shifted westward to the coastline of New England and Newfoundland. Expanding New England fisheries increasingly took on the role of West Indian supplier, while the Newfoundland fisheries shipped to markets in Iberia and the Wine Islands. As the New England cod fishing industry expanded, colonists took greater control over their maritime commerce. West Country merchants still commanded the Newfoundland fisheries

Salt Cod and Its Institutions in the Interwar Period,” International Journal of Maritime History, Vol. 17, No. 2 (December, 2005), 61-85, esp. 67, and Figure 1: "Percentage Distribution of World Dried Salted Cod Imports by Country, 1920-1947.” Portugal's historic dependence on foreign cod, “the cod problem,” had become so pronounced by the twentieth century that, on average, $89.8 \%$ of the dried cod consumed in the region between 1900 and 1933 had been imported. Even during this modern period, much of this cod trade was controlled by businessmen in England. Ibid., 63n, 69n. In short, fish merchants in England dominated Iberian markets over an extended period of time.

${ }^{169}$ Carrington, The British West Indies During the American Revolution, 44, Table 30. 
throughout the eighteenth century. And London financiers still floated credit to the New England merchants to cover costs of manufactured goods not covered through sales. Yet, the colonies no longer depended on supplies of transient laborers from England and catches were transported on local shipping. Also, Yankee traders brokered overseas deals without Englandbased middlemen. Such expansion and autonomy came with political costs, however. The political ramifications of New England's expanding role in the Atlantic economy will be dealt with in the following chapter. 


\subsection{COD AND ATLANTIC ORIGINS OF THE AMERICAN REVOLUTION}

"A reformation [in trade regulations] is become necessary....But should such restraints take place as to discourage the trade, and destroy the fishery of the northern colonies; Great Britain, instead of benefiting itself by its conquests [i.e. Canada and Newfoundland, which were taken in the Seven Years' War], has only added a load which it must at length sink under." "Montesquieu," Boston Evening Post, November 21, 1763.

"A small Weight added to a Burthen a Man staggers under, will crush and sink him.” Essex Gazette, September 13-September 20, 1768, in an article on Parliamentary taxation.

The origins of the American Revolution cannot be adequately explained without investigating why merchants and workers in the New England cod fishing industry decided to resist British authority. First and foremost, it is widely recognized that the Revolution began in New England, especially in Massachusetts. Riots against Parliamentary authority were particularly prevalent in the region throughout the 1760s and early 1770s. In these mob activities, effigies and customs vessels were burned; customs officials and royal governors were forced to watch their property being destroyed; monopolized tea became flotsam and jetsam; and British soldiers were harassed to the point at which they were willing to shoot into a crowd of unarmed colonists. ${ }^{1}$ Moreover,

\footnotetext{
${ }^{1}$ Alfred F. Young, The Shoemaker and the Tea Party: Memory and the American Revolution (Boston: Beacon Press, 1999); Andrew S. Walmsley, Thomas Hutchinson and the Origins of the American Revolution (New York: New York University Press, 1999); Edmund S. Morgan and Helen M. Morgan, The Stamp Act Crisis: Prologue to Revolution, $3^{\text {rd }}$ ed., (Chapel Hill: The University of North Carolina Press, 1995); Gary B. Nash, The Urban Crucible: Social Change, Political Consciousness, and the Origins of the American Revolution (Cambridge: Harvard University Press, 1979); Dirk Hoerder, Crowd Action in Revolutionary Massachusetts, 1765-1780 (New
} 
the idea to boycott British manufactured goods and use consumer power as a political weapon began in New England; militia units were formed here with the intention of resisting British authority at a minute's notice; elites in this region first established committees of correspondence to unite colonists in opposition; and the "shot heard around the world" came at Concord, Massachusetts. ${ }^{2}$ Additionally, according to the most-cited military historian of the American Revolutionary War, "Massachusetts put a larger percentage of her population in the field [during the war] than any other state.”3

Massachusetts was the foremost fishing colony, yet the commercial cod fishing industry played an important role throughout New England's economic life. Dried cod represented the most lucrative export in the entire region. Revenue from commercial fishing and the production of dried cod brought in trade goods from the West Indies and Southern Europe, foodstuffs from Connecticut and colonies in the Mid-Atlantic and Southern regions, along with manufactured goods from Great Britain. The returns made in molasses from the West Indies alone were crucial in terms of fueling distilleries across the New England colonies. And the fishing industry had an economic spread effect that benefited secondary industries in the region such as lumbering, shipbuilding, and farming. ${ }^{4}$ Coming to terms with why New England fishermen and fish

York: Academic Press, 1977); Eric Foner, Tom Paine and Revolutionary America (New York: Oxford University Press, 1976); Bernard Bailyn, The Ordeal of Thomas Hutchinson (Cambridge: Harvard University Press, 1974); and Thomas C. Barrow, Trade and Empire: The British Customs Service in Colonial America, 1660-1775 (Cambridge, Mass., 1967).

${ }^{2}$ T.H. Breen, The Marketplace of Revolution: How Consumer Politics Shaped American Independence (Oxford: Oxford University Press, 2004); Robert A. Gross, The Minutemen and Their World (New York: Hill and Wang, 1976); Pauline Maier, From Resistance to Revolution: Colonial radicals and the development of American opposition to Britain, 1765-1776 (New York: Vintage Books, 1972); and John Shy, Toward Lexington: The Role of the British Army in the Coming of the American Revolution (Princeton: Princeton University Press, 1965).

${ }^{3}$ Don Higginbothom, The War of American Independence: Military Attitudes, Policies, and Practice, 17631789, $2^{\text {nd }}$ ed., (Boston: Northeastern University Press, 1983), 389.

${ }^{4}$ See the preceding two chapters. 
merchants were among the first to resist British authority will therefore go a long way toward explaining the very origins of the American Revolution.

For nearly a century, much ink has been spilled in various attempts to clarify why the thirteen North American colonies fought a war against their own government. For the most part, historians have waded into two contested pools: the debate over ideological and material causations; and the contest over local and global factors behind the Revolution. ${ }^{5}$ The former debate is the most long-standing. Over the course of the nineteenth century, scholars collectively known as the "Whig" school developed a rationalization for the Revolution that emphasized ideological motivations. ${ }^{6}$ These scholars tended to celebrate the Founding Fathers, who heroically united disparate colonies to defend freedom and liberty against a tyrannical monarch and his corrupt friends in Parliament. The Whigs blamed George III for causing the imperial rupture, and they lauded the colonial leaders for their righteous cause. The "Progressive" school then rose in reaction against this celebratory interpretation. ${ }^{7}$ They emphasized internal conflict over consensus and economic determinants over ideological origins. Moreover, the Progressives tended to view the Revolution as a social movement more than a march of ideas. By the middle

\footnotetext{
${ }^{5}$ In 1957, Edmund S. Morgan believed "three ideas" dominated the historiography on the origins of the American Revolution: that the thirteen North American colonies must be seen as part of the wider British Empire; social and economic divisions in the colonies influenced the course of colonial history; and that local forces mattered as much or more than "national" decisions. Edmund S. Morgan, "The American Revolution: Revisions in Need of Revising,” The William and Mary Quarterly, $3^{\text {rd }}$ Series, Vol. 14, No. 1 (January, 1957), 3-15, esp. 3-4. As late as 1988, Marc Egnal maintained there were "three schools of thought" on the origins of the Revolution: "the Imperial, Progressive, and Neo-Whig" schools. Marc Egnal, A Mighty Empire: The Origins of the American Revolution (Ithaca, New York: Cornell University Press, 1988), 1-2. Each of these ideas, or schools of thought, will be addressed here, along with a fourth concept that has emerged recently - the Atlantic approach.

${ }^{6}$ George Bancroft, History of the American Revolution, 7 vols., (Boston: Little, Brown \& Company, 18521874); and George Otto Trevelyan, The American Revolution, 3 vols., (New York: Longmans, Green, and Co., 1899-1907). The British historian Herbert Butterfield coined the phrase "Whig history" in order to describe an interpretation that emphasizes the constant, inevitable march of history, and which presents past political figures in stark terms as heroes or villains. Butterfield, The Whig Interpretation of History (London: G. Bell and Sons, 1931).

${ }^{7}$ J. Franklin Jameson, The American Revolution Considered As A Social Movement (Princeton: Princeton University Press, 1926); Arthur Meier Schlesinger, The Colonial Merchants and the American Revolution, 17631776 (New York: Columbia University, 1918); Charles A. Beard, An Economic Interpretation of the Constitution of the United States (New York: The Macmillan Company, 1913); and Carl Lotus Becker, The History of Political Parties In the Province of New York, 1760-1776 (Madison: University of Wisconsin Press, 1909).
} 
of the century, a group of scholars labeled "neo-Whigs" swung the pendulum back toward the ideological end of the spectrum. While the Cold War got hotter, these scholars saw Revolutionary America as a bastion of liberty helping to save, and then spread, democracy in the world. ${ }^{8}$ Unsatisfied with Progressives' emphasis on conflict at home and economic stimuli, yet disaffected with the Whigs' focus on George III, the neo-Whigs located the British conspiracy to strip colonists of their political liberties in a corrupt Parliamentary faction headed by Lord North. In this interpretation, educated, wealthy colonial elites were once again lauded for creating a consensus in the colonies regarding the righteousness of revolution. The neo-Whigs, however, unlike their predecessors, provided a more detailed analysis of the Founding Father's political ideas that explored concern for traditional constitutional rights and fears associated with tyranny. Around the same time, "New Left” historians took the Progressive’s interest in material concerns and began to explore more deeply why those outside educated, wealthy elite circles decided to resist British authority during the imperial crisis. ${ }^{9}$ Through their work, it became clear that

\footnotetext{
${ }^{8}$ See, Bernard Bailyn, The Ideological Origins of the American Revolution (Cambridge: Harvard University Press, 1967); and R.R. Palmer, The Age of the Democratic Revolution, 2 vols., (Princeton: Princeton University Press, 1959-1964). For studies less influenced by the Cold War, but no less focused on ideology, see Trevor Colbourn, The Lamp of Experience: Whig History and the Intellectual Origins of the American Revolution (Cambridge: Harvard University Press, 1967); and Caroline Robbins, The Eighteenth-Century Commonwealthman: Studies in the Transmission, Development and Circumstance of English Liberal Thought from the Restoration of Charles II until the War with the Thirteen Colonies (Cambridge: Harvard University Press, 1959). One sympathetic scholar has recently referred to the Neo-Whig ideological interpretation as "the most appealing explanation" for why the Revolution took place. Breen, The Marketplace of Revolution, 8. Breen does critique Bailyn's interpretation. However, the former believes "studies of the material experience of everyday life in colonial America have yielded even less insight into the dynamics of political mobilization." He goes on to explain: "No doubt, various free, white Americans believed that they had in some measure been wronged by economic practices that paid them less than they thought they deserved for their labor or crops. But however irritating these issues may have been, they do not appear to have shaped significantly either the character or intensity of political commitment beyond the boundaries of the local community." Ibid., 9. For his part, Egnal has referred to "the neo-Whig paradigm" as "the accepted explanation" for the origins of the Revolution. Egnal, A Mighty Empire, 3.

${ }^{9}$ Edward Countryman, A People In Revolution: The American Revolution and Political Society in New York, 1760-1790 (Baltimore: Johns Hopkins University Press, 1981); Nash, The Urban Crucible; Philip S. Foner, Labor and the American Revolution (Westport, Conn.: Greenwood Press, 1976); Jesse Lemisch, "The American Revolution Seen From the Bottom Up," in Barton J. Bernstein, ed., Towards a New Past: Dissenting Essays in American History (New York: Pantheon Books, 1968), 3-45; Alfred F. Young, The Democratic Republicans of New York: The Origins, 1763-1797 (Chapel Hill: The University of North Carolina Press, 1967); and Staunton Lynd,
} 
laborers were less concerned with constitutional rights and more alarmed at the widening disparity between rich and poor in the colonies. Colonial elites were successful at linking this alarm to what they perceived as a corrupt imperial political system, thus mobilizing the masses. Naval impressment in colonial port cities and the increasing inability of working men and women in the colonies to purchase their own land further inflamed public sentiment against the British Empire. Currently, this debate has not shown signs of deceleration or resolution. ${ }^{10}$

Studies emphasizing micro and macro level causations have further intensified and broadened our understanding of the Revolution's genesis. Shortly after World War I, the renowned British historian Sir Lewis Namier probed Parliamentary records for evidence that political parties had formed in early modern England and influenced the course of colonial policy on the eve of the American Revolution. ${ }^{11}$ Namier demonstrated that factions within Parliament, as opposed to organized political parties, formed around personal interests. Internal rivalries, he believed, contributed to the vacillations in state policy between salutary neglect and intervention, ultimately leading to the imperial rupture. Any study of the origins of the Revolution, Namier believed, had to start and end in Whitehall. American scholars, on the other hand, came to believe that colonial rebellion could only be explained by investigating colonial town life. The

Anti-Federalism in Dutchess County, New York: A Study of Democracy and Class Conflict in the Revolutionary Era (Chicago: Loyola University Press, 1962).

${ }^{10}$ Recent arguments in favor of the material origins of the American Revolution include Alfred F. Young, Liberty Tree: Ordinary People and the American Revolution (New York: New York University Press, 2006); Gary B. Nash, The Unknown American Revolution: The Unruly Birth of Democracy and the Struggle to Create America (New York: Viking, 2005); and Nancy L. Rhoden and Ian K. Steele, eds., The Human Tradition In the American Revolution (Wilmington, DE: Scholarly Resources Inc., 2000). For newer arguments on the ideological side, see Bernard Bailyn, To Begin the World Anew: the Genius and Ambiguities of the American Founders (New York: Knopf, 2003); Jack P. Greene, Understanding the American Revolution: Issues and Actors (Charlottesville: University Press of Virginia, 1995); and Robert M. Calhoon, Dominion and Liberty: Ideology in the AngloAmerican World, 1660-1801 (Arlington Heights, IL: Harlan Davidson, 1994). Breen’s latest work probes political culture and material culture in the colonies in order to get at the origins of the American Revolution. Breen, The Marketplace of Revolution.

${ }^{11}$ See, Sir Lewis Namier, England in the Age of the American Revolution (London: MacMillan and Co., Limited, 1930); and idem., The Structure of Politics at the Accession of George III, 2 Vols., (London: MacMillan and Co., Limited, 1929). 
town study emerged in the 1970 s as a separate genre of colonial American history. ${ }^{12}$ These investigations primarily looked at the transition to capitalism and the impact this had on communal life. The town studies then inspired inquires into the origins of the Revolution that focused on specific communities. ${ }^{13}$ It was found that overpopulation and underemployment in some towns generated large numbers of disaffected, listless youths in search of a cause. In other areas, we are told, deferential politics reigned supreme and townsfolk simply acquiesced to men they viewed as their social-betters. As a result of this emphasis on more localized causations, some historians have adopted the position that each colonial region maintained different and distinct justifications for revolting against the Empire that must be understood on their own terms. $^{14}$

The emphasis on localized causations has not satisfied everyone. The "Imperial school" of scholars were the first to react against the Whigs' tendency to examine the colonies in

\footnotetext{
${ }^{12}$ See, Christine Leigh Heyrman, Commerce and Culture: The Maritime Communities of Colonial Massachusetts, 1690-1750 (New York: W.W. Norton \& Company, 1984); Edward M. Cook, Jr., The Fathers of the Towns: Leadership and Community Structure in Eighteenth-Century New England (Baltimore: The Johns Hopkins University Press, 1976); Kenneth Lockridge, A New England Town, The First Hundred Years, Dedham, Massachusetts, 1636-1736 (New York: W.W. Norton \& Company, 1970); John Demos, A Little Commonwealth: Family Life in Plymouth Colony (New York: Oxford University Press, 1970); Philip J. Greven, Jr., Four Generations: Population, Land, and Family in Colonial Andover, Massachusetts (Ithaca: Cornell University Press, 1970); and Michael Zuckerman, Peaceable Kingdoms: New England Towns in the Eighteenth Century (New York: W. W. Norton and Company, Inc., 1970).

${ }^{13}$ See, Richard L. Bushman, King and People in Provincial Massachusetts (Chapel Hill: North Carolina University Press, 1985); William Pencak, War, Politics, \& Revolution in Provincial Massachusetts (Boston: Northeastern University Press, 1981); Richard Buel, Jr., Dear Liberty: Connecticut's Mobilization for the Revolutionary War (Middletown, Conn.: Wesleyan University Press, 1980); Gross, The Minutemen and Their World; Benjamin W. Labaree, Patriots and Partisans: The Merchants of Newburyport, 1764-1815 (New York: W.W. Norton \& Company, Inc., 1975). More recently, scholars who have rooted the origins of the American Revolution in localized colonial concerns include Phyllis Whitman Hunter, Purchasing Identity in the Atlantic World: Massachusetts Merchants, 1670-1780 (Ithaca, NY: Cornell University Press, 2001); and Gordon S. Wood, The Radicalism of the American Revolution (New York: Alfred A. Knopf, 1992).

${ }^{14}$ See, for example, Stephen J. Hornsby, British Atlantic, American Frontier: Spaces of Power In Early Modern British America (Hanover: University Press of New England, 2005); and Jack P. Greene, Pursuits of Happiness: The Social Development of Early Modern British Colonies and the Formation of American Culture (Chapel Hill: The University of North Carolina Press, 1988). On the other hand, Breen maintains that "unless an interpretation of the coming of the American Revolution comprehends the political mobilization of that 'huge massy body,' [i.e. colonists in all of the colonies] it does not tell us very much at all.” Breen, The Marketplace of Revolution, 8.
} 
isolation, and they further rejected Namier's focus on personal politics in Whitehall. This school

has emphasized the impact Parliamentary decisions had on political and economic development

throughout the colonies, and in so doing they shifted our perspective of the causes of the Revolution from the micro to the macro level. ${ }^{15}$ Collectively, these scholars firmly situated the thirteen North American colonies within a distinctly British political and economic world system. They argued that the British state did a fair and benevolent job of running the empire prior to the Revolution, as evidenced by the economic expansion that took place in the colonies between the seventeenth and eighteenth centuries, and the fact that the imperial rupture did not take place until $1776 .{ }^{16}$ The cause of the Revolution in this interpretation is laid solely on the doorstep of colonists who unnecessarily grumbled about paying taxes, rioted, and boycotted British manufactured goods all because they had been used to a system of salutary neglect and were now being forced to take seriously their status as British subjects. This interpretation

\footnotetext{
${ }^{15}$ Ian R. Christie and Benjamin W. Labaree, Empire or Independence, 1760-1776 (New York: W. W. Norton \& Company, Inc., 1976); James A. Henretta, "Salutary Neglect": Colonial Administration Under the Duke of Newcastle (Princeton: Princeton University Press, 1972); Lawrence Henry Gibson, The British Empire Before the American Revolution, Vols. 1-15, (New York: Alfred A. Knopf, 1939-1970); Jack M. Sosin, Agents and Merchants: British Colonial Policy and the Origins of the American Revolution, 1763-1775 (Lincoln, Nebraska: University of Nebraska Press, 1965); Charles M. Andrews, The Colonial Background of the American Revolution (New Haven: Yale University Press, 1931); Leonard Labaree, Royal Government in America: A Study of the British Colonial System Before 1783 (New Haven, CT: Yale University Press, 1930); George Louis Beer, The Old Colonial System, 1660-1754 (New York: The MacMillan Company, 1912). More recent work that maintains the Imperial school's focus on causations within the British Empire include Eliga H. Gould and Peter S. Onuf, eds., Empire and Nation: The American Revolution in the Atlantic World (Baltimore: Johns Hopkins University Press, 2005); Hornsby, British Atlantic, American Frontier; Bailyn, To Begin the World Anew; David Armitage and Michael Braddick, eds., The British Atlantic World, 1500-1800 (London: Palgrave, 2002); Elizabeth Mancke and Carole Shammas, eds., The Creation of the British Atlantic World (Baltimore: The Johns Hopkins University Press, 2005); Andrew Jackson O'Shaughnessy, An Empire Divided: The American Revolution and the British Caribbean (Philadelphia: University of Pennsylvania Press, 2000); Alison Gilbert Olson, Making the Empire Work: London and American Interest Groups, 1690-1790 (Cambridge: Harvard University Press, 1992); Selwyn H.H. Carrington, The British West Indies During the American Revolution (Providence, RI: Foris Publications, 1988); and Egnal, A Mighty Empire.

${ }^{16}$ Recently, Olson has discussed Andrews' work and she has taken it on faith that "for over a hundred a fifty years before they rebelled, American colonists were loyal subjects of the British monarch" because the empire worked for them. Olson also states that colonists "generally obeyed the Navigation Acts" and "submitted with relatively little complaint to a government overseas.” Olson, Making the Empire Work, xi-xii, 1.
} 
further privileged the concept of mercantilism. ${ }^{17}$ That is to say, the Imperial school took for granted the fact that the colonies were supposed to be producing goods and wealth to be exchanged for items manufactured in England. Colonists that violated this economic system were, in a way that would have made Lord North smile, deemed smugglers and unworthy subjects.

Over the last thirty years, the Imperial school's analytical framework has been widened and deepened through studies that have seriously considered the origins of the Revolution from a supra-imperial perspective. J.G.A. Pocock first began to factor into causation forces beyond the boundaries of empire. ${ }^{18}$ By examining the impact of Italian classical republican discourse on English political theory, Pocock traces the long duré of ideologies surrounding liberty and virtue that American revolutionaries employed in their critique of the British state. In effect, he has taken the Whigs and neo-Whigs' ideological emphasis to new limits in terms of space and time. Peter Linebaugh and Marcus Rediker, on the other hand, have recently expanded on the Progressive and New Left focus on material life and history from below. They observe the ways in which dissatisfaction among African slaves and multiethnic maritime workers contributed to demands for systemic change in the late eighteenth century. ${ }^{19}$ In addition, recent work on the Atlantic economy has challenged the dominant wisdom that mercantilism defined a majority of

\footnotetext{
${ }^{17}$ For more on mercantilism, see Immanuel Wallerstein, Mercantilism and the consolidation of the European world-economy (New York: Academic Press, 1980). World systems theory, which maintains a rigid focus on the interaction between the core and the periphery, is in fact more representative of imperial history than Atlantic history. Also, see Michael G. Kammen, Empire and Interest: The American Colonies and the Politics of Mercantilism (Philadelphia, PA: Lippincott, 1970). Kammen focuses on the ways in which mercantilist policies were shaped to benefit British economic interests. He does not look at the commercial fishing industry, nor does his examination go beyond the boundaries of the British Empire. According to Charles M. Andrews, mercantilist economic policies originated in the commercial rivalry between England, France, and the Netherlands during the seventeenth century. Charles M. Andrews, “Anglo-French Commercial Rivalry, 1700-1750: The Western Phase, I," The American Historical Review, Vol. 20, No. 3 (April, 1915), 539-556.

${ }^{18}$ J.G.A. Pocock, The Machiavellian Moment: Florentine Political Thought and the Atlantic Republican Tradition (Princeton: Princeton University Press, 1975).

${ }^{19}$ Peter Linebaugh and Marcus Rediker, The Many-Headed Hydra: Sailors, Slaves, Commoners, and the Hidden History of the Revolutionary Atlantic (Boston: Beacon Press, 2000).
} 


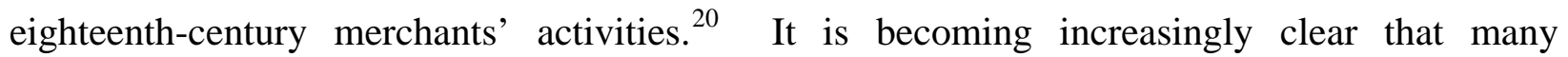
entrepreneurs acted in their individual self-interests and pursued their own agendas irregardless of political boundaries and commercial regulations. ${ }^{21}$

Despite this plethora of excellent scholarship, to date no work has simultaneously situated New England in a wider Atlantic context and discussed the roles the fishing industry played in precipitating the American Revolution. This chapter will demonstrate that the commercial expansion of New England's cod fishing industry and trade along the Northwest Atlantic littoral and in the West Indies bears directly on the study of those material factors responsible for the American Revolution. Economic pressure from outside the British Empire, chiefly from French Atlantic possessions, generated divisions within the Empire, particularly between New England and West Indian merchants. At the same time, a greater New England presence in the North Atlantic posed a direct threat to the commercial interests of West Country fish merchants, driving a wedge between these groups. The fact that the British state sided with West Indian and West Country interests exasperated these internal divisions and ultimately fractured colonial loyalty to the Empire.

\footnotetext{
${ }^{20}$ Peter A. Coclanis, ed., The Atlantic Economy During the Seventeenth and Eighteenth Centuries: Organization, Operation, Practice, and Personnel (Columbia, SC: University of South Carolina Press, 2005). Several different essays in this volume specifically address the limits of mercantilism in the eighteenth century. Especially see David Hancock, "Self-Organized Complexity and the Emergence of an Atlantic Market Economy, 1651-1815," in ibid., 30-71. Also, see Simon D. Smith, "Gedney Clarke of Salem and Barbados's Transatlantic Super-Merchant,” New England Quarterly, Vol. 76, No. 4 (December 2003), 499-549, esp. 543-544; A. J. R. Russell-Wood, "Centers and Peripheries in the Luso-Brazilian World, 1500-1808," and Leslie Choquette, "Center and Periphery In French North America," in Christine Daniels and Michael V. Kennedy, eds., Negotiated Empires: Centers and Peripheries in the Americas, 1500-1820 (New York: Routledge, 2002), 105-142, 193-206; and Stanley J. Stein and Barbara H. Stein, Silver, Trade, and War: Spain and America in the Making of Early Modern Europe (Baltimore: Johns Hopkins University Press, 2000).

${ }^{21}$ Indeed, Bernard Bailyn has gone so far as to recently assert "mercantilist theories, national rivalries, and nationalist historiography obscure the degree to which a stable pan-Euro-Afro-American economy developed....Despite all the commercial hostilities between rival nations and competitive interests, the pan-oceanic commercial webs that developed as the Atlantic world matured were interwoven, complex, and multitudinous." Bernard Bailyn, Atlantic History: Concept and Contours (Cambridge, MA: Harvard University Press, 2005), 83-84.
} 


\subsection{NEW ENGLAND'S ECONOMIC EXPANSION IN THE WEST INDIES}

Chapter three demonstrated that New England increasingly took on the role of supplier for West Indian markets in the eighteenth century. In particular, the principal role of the New England cod fisheries in the Atlantic economy became provisioning slave plantations. The development of a sugar monoculture in the West Indies and the explosion of slave populations in the region generated greater and greater demand for imported food-stuffs. The protein found in inexpensive, refuse grades of dried cod helped fuel coerced laborers and thereby contributed to the production of sugar and its byproducts. Cod fishermen responded to this demand by producing even more refuse cod then the British islands could absorb.

Most of New England's most lucrative export commodity, therefore, had to be shipped outside the bounds of the British Empire. This point was made by Edward Payne, a Boston fish merchant and member of the Society for the Encouragement of Trade and Commerce in the 1760s. His "Own Vessels caught more Fish than the generality of the Vessels in that Town did." 22 He therefore understood that, "This valuable branch of our Trade, the Fishery almost, if not wholly, depends on our Trade to the Foreign Islands in the West Indies."23 "In return," Payne wrote on a separate occasion, "we receive Molasses \& a small proportion of ordinary Sugars.”24

People who worked in the New England fishing industry consumed West Indian sugar products. According to one expert witness called to testify before Parliament in 1766, "the poorer sort of people in North America,” which included a majority of those who worked in the

\footnotetext{
${ }^{22}$ Sworn testimony of Edward Payne of Boston, merchant, dated Boston, December, 1763, Ezekiel Price Papers, 1754-1785, MHS.

${ }^{23}$ Letter from Edward Payne, Ezekiel Price Papers, 1754-1785, MHS.

24 "In the Preamble to a late Act of Parliament," 1764, attributed to Edward Payne, Ezekiel Price Papers, 17541785, MHS.
} 
cod fishing industry, "use the [imported West Indian] molasses in making small beer."25 Maritime laborers in the industry also had a reputation for drinking large quantities of rum. The same witness testified in 1766 that West Indian molasses “imported into North America” was "principally to be distilled into rum which is employed in carrying on the fishery and the Guinea trade.”26 According to Daniel Vickers, “fishing crews departing on four-to-eight-week voyages normally carried about 12 gallons of rum and at least 60 gallons of cider (Imperial measure). Among a crew of seven or eight members (including two to four boys), this would amount to roughly a quart of cider and six ounces of rum per fishermen per day.” ${ }^{27}$ By this conservative estimate, the average seven-man schooner could consume up to 2,352 ounces, or 14.7 gallons, of rum (Imperial measure) per voyage. Fish merchants counted 301 schooners in Massachusetts in 1763. Therefore, the off-shore fishing fleet from this single colony would have consumed 4,410 gallons of rum per voyage. ${ }^{28}$ Typically, these types of fishing vessels made three fares each year. Assuming each vessel stayed at sea for eight weeks, Massachusetts’ deep sea fishing fleet, the largest fleet in all of the colonies, would have consumed 13,230 gallons annually. ${ }^{29}$ This rum was both imported directly from the West Indies and distilled from imported molasses in the colonies. Moreover, rum was consumed domestically and it was shipped to Newfoundland to

${ }^{25}$ PDBP, Vol. 2, 362.

${ }^{26}$ PDBP, Vol. 2, 360. The same colonial merchant later testified "that the fisheries would take off more rum than the Guinea trade, but that both will take off great quantity.” Ibid., 364.

${ }^{27}$ Daniel Vickers, Farmers and Fishermen: Two Centuries of Work in Essex County, Massachusetts, 1630-1830 (Chapel Hill: The University of North Carolina Press, 1994), 182, footnote 61. Vickers cautions, "This must be regarded as a minimal estimate since crew members sometimes purchased more in ports closer to the grounds."

${ }^{28}$ Benjamin Pickman and Samuel Gardner of Salem, to John Rowe, Esq., and others Committee of the Society for Encouraging Trade \& Commerce located in Boston, letter dated Salem, December 24, 1763, Ezekiel Price Papers, 1754-1785, MHS.

${ }^{29}$ This estimate does not take into account smaller, inshore vessels, such as shallops, nor does it include fishing fleets from other colonies. Though none of these numbers would have been as large as Massachusetts' off shore fishing fleet in the 1760s, they would substantially increase the amount of rum consumed in the entire New England fishing industry. 
supply fishermen there. ${ }^{30}$ A writer concerned with the Newfoundland fishery explained in 1807 that without access to "strong drink" "it would be impossible to continue the [fishing] trade [i.e. industry], for ten hours in the boats every day in the summer and the intolerable cold of the winter makes living hard." ${ }^{31}$ New England was thus an importer and an exporter of an alcoholic beverage that eased the plight of the working man.

When the rum and molasses was imported from the West Indies, more often than not these sugary goods came from French islands. Yankees developed strong commercial relations with French islands in the West Indies despite their religious differences and severe French penalties. $^{32}$ Opportunistic businessmen saw certain economic advantages to trade with the principal competitors of British West Indian planters, especially because French planters offered the lowest prices for sugar and its by-products. Throughout the eighteenth century the price differential between British and French West Indian sugar ranged between 25-33\% in favor of

\footnotetext{
${ }^{30}$ In 1763 alone, 49,140 gallons of rum were shipped out of Boston to Newfoundland. This figure represents 85.6\% of all rum exported from the colonies to Newfoundland. See, C. Grant Head, Eighteenth Century Newfoundland (Toronto: McClelland and Stewart Limited, 1976), 120, Table 6.10. Ralph Greenlee Lounsbury dates the genesis of New England's rum shipments to Newfoundland at 1675. Ralph Greenlee Lounsbury, The British Fishery at Newfoundland 1634-1763 (New Haven, CT: Yale University Press, 1934; reprinted New York: Archon, 1969), 191-192. However, Peter Pope, C. Grant Head, and Bernard Bailyn maintain that Boston merchants were trading general supplies, of which rum may have been involved, as early as 1640 . Peter E. Pope, Fish Into Wine: The Newfoundland Plantation in the Seventeenth Century (Chapel Hill: The University of North Carolina Press, 2004), 151; Head, Eighteenth Century Newfoundland, 111; and Bernard Bailyn, The New England Merchants in the Seventeenth Century, 3rd ed., (Cambridge, Mass.: Harvard University Press, 1982), 129.

${ }^{31}$ Quote taken from Harold Adams Innis, The Codfisheries: The History of an International Economy (New Haven: Yale University Press, 1940), 103. According to Innis, as a result of fishermen's great consumption of alcohol there were 74 taverns in Newfoundland in 1723, 50 in St. John's alone. The figure for Newfoundland increased to 122 in 1750. Ibid., 153-154. For an excellent discussion of seventeenth century fishermen and their consumption of alcohol, see Pope, Fish Into Wine, 393-401.

${ }^{32}$ In an effort to restrict the sale of sugar to the Mother Country, France prohibited foreign trade with its West Indies in 1717. Foreign merchants who violated this general prohibition were liable, after a set of laws passed in 1727, to have their vessels and cargoes confiscated. French merchants who engaged in illicit trade risked being sentenced to labor on galleys. Trade with foreign merchants was made legal in 1764, however French planters were strictly forbidden to import dried cod from New England. Dorothy Burne Goebel, "The 'New England Trade' and the French West Indies, 1763-1774: A Study in Trade Policies,” The William and Mary Quarterly, $3^{\text {rd }}$ Series, Vol. 20, No. 3 (July, 1963), 332, 335-336. The focus of this article is on French attempts to maintain a mercantilist economic policy.
} 
the French. ${ }^{33}$ This comparative price advantage was the result of several factors. France's possessions enjoyed certain natural advantages, including fertile soil and better access to water resources with which to power mills and irrigate fields. The French islands also maintained a more elaborate tax system that financed roads, canals, port facilities, and scientific research pertaining to improving plant variety and processing techniques. As a result, the French islands became increasingly productive throughout the eighteenth century. By 1770, the combined output of French sugar plantations had exceeded that of rival British plantations. ${ }^{34}$ By 1775, the plantations on St. Domingue (Haiti) alone surpassed the production of all the British islands combined. $^{35}$ Increased production made French West Indian sugar readily available and relatively inexpensive.

French molasses could also be easily had and for low prices. Molasses was a by-product of the process of converting raw cane into commercial grade sugar. ${ }^{36}$ French planters were able to produce a high grade sugar by draining-off more of the molasses through the production process. ${ }^{37}$ They therefore had more molasses to sell than their British counterparts. Moreover, French planters were somewhat desperate to vend this particular by-product, as their choice of markets became greatly restricted over the course of the eighteenth century. At the beginning of the century the French government prohibited the importation of molasses into France, an enormous market with one of the largest populations in all of Europe. This prohibition was

\footnotetext{
${ }^{33}$ O'Shaughnessy, An Empire Divided, 60-65; Richard S. Dunn, Sugar and Slaves: The Rise of the Planter Class in the English West Indies, 1624-1713, ${ }^{\text {nd }}$ ed., (New York: W.W. Norton \& Company, Inc., 1973), 205; and Charles M. Andrews, “Anglo-French Commercial Rivalry, 1700-1750: The Western Phase, II,” The American Historical Review, Vol. 20, No. 4 (July, 1915), 763.

${ }^{34}$ Robin Blackburn, The Making of New World Slavery (London: Verso Press, 1997), 432, 438; Andrews, “Anglo-French Commercial Rivalry, 1700-1750: The Western Phase, I,” 550-551.

${ }_{35}$ O’Shaughnessy, An Empire Divided, 60-61.

${ }^{36}$ The most comprehensive description of the process involved in early modern sugar production that led to molasses can be found in Stuart B. Schwartz, Sugar Plantations in the Formation of Brazilian Society: Bahia, 15501835 (Cambridge: Cambridge University Press, 1985), 98-131, esp. 119-121.

${ }^{37}$ Blackburn, The Making of New World Slavery, 434.
} 
meant to protect the domestic brandy industry from competition. ${ }^{38}$ Prior to the Seven Years' War, the French Islands could sell molasses to Canadian markets. However, as Payne wrote in 1764: "Molasses is a Commodity the French have no Market to vend it at since the Reduction of Canada. Therefore, they allow us to bring our Fish \& lumber to their Islands to purchase it. We want this Article to support our Fishery \& carry on our other Trade.”39 The shrinkage of available markets made French planters very willing to sell to New England buyers, and such pressures continually drove down the price of French West Indian molasses.

The French comparative price advantage contributed to cod's extended purchasing power in their ports. Between 1700-75, the price of New England refuse cod ranged between 3.9-11.3 shillings per quintal. ${ }^{40}$ Between $1720-75$, the price of West Indian muscovado sugar, for which there are the most extensive price records, ranged between 10-45 shillings per hundredweight in the islands. ${ }^{41}$ All things being equal, then, 100 quintals of refuse grade dried cod, at a median rate of 7.6 shillings per quintal, would have been worth 760 shillings in the West Indies for much of the eighteenth century. However, because of the price differential that existed between British and French sugar at this time, New England fish merchants could buy

${ }^{38}$ O’Shaughnessy, An Empire Divided, 62; and Innis, The Codfisheries, 175-176. According to Andrews, neither molasses nor rum was in great demand in eighteenth-century France. "Molasses was not palatable to the French taste, and the French people would not use it as food, so that the French island planters were compelled to give it to their horses or pigs or to throw it away, while rum was not wanted, because it was too raw a liquor for drinking purposes, and was discouraged because it competed when used with wines and brandies, which ranked high among French staples.” Andrews, “Anglo-French Commercial Rivalry, 1700-1750: The Western Phase, I,” 556.

39 "In the Preamble to a late Act of Parliament," 1764, attributed to Edward Payne, Ezekiel Price Papers, 17541785, MHS.

${ }^{40}$ Daniel Vickers, "`A Knowen and Staple Commoditie': Codfish Prices in Essex County, Massachusetts, 16401775," Essex Institute, Historical Collections, Vol. CXXIV, (Salem, MA: Newcomb and Gauss, 1988), 198-202, Table 1. John J. McCusker has recently reminded us that we must take these cod prices with a grain of salt, as weights and measurements were not standardized around the Atlantic world, and as there were variations in coinage in use throughout the early modern period. See, John J. McCusker's remarks in "Roundtable Reviews of Peter E. Pope, Fish into Wine: The Newfoundland Plantation in the Seventeenth Century with a Response by Peter E. Pope," in International Journal of Maritime History, Vol. 17, No. 1 (June, 2005), 251-261.

${ }^{41}$ John J. McCusker and Russell R. Menard, The Economy of British America, 1607-1789 (Chapel Hill, North Carolina: The University of North Carolina Press, 1985), 157-159, esp. Figure 7.1. 
more sugar in the French islands. Assuming a median price differential of $29 \%$ and a median sugar rate of 27.5 shillings per hundredweight, 100 quintals of refuse grade dried cod could be exchanged for slightly more than 21 hundredweights of sugar in the British islands, while the same amount of cod could fetch almost 28 hundredweights in the French islands. In this example, New England merchants could purchase 33\% more sugar with the French planters than they could otherwise have done with the British planters using the same amount of fish in exchange. Such purchasing power would have then carried over to by-products manufactured from sugar such as molasses.

French West Indian markets for refuse grade dried cod were also expanding at a faster pace than rival British markets during the eighteenth century. To be sure, Great Britain gained control over French territory in the West Indies through the course of several wars and British planters owned more slaves than their French counterparts prior to the American Revolution (434,000 compared to 393,000 in 1770). However, the slave population on French islands expanded 4.2 times between 1700 and 1740, and then again by 1.7 times between 1740 and 1770. By comparison, the slave population on British islands only increased 2.2 times and 1.7 times, respectively. ${ }^{42}$ In other words, between 1700 and 1770, the slave population of the French islands grew 7.3 times (from 54,000 to 393,000), while the same population of the British islands only increased 3.8 times (from 115,000 to 434,000). For New England fish merchants, these slaves represented prospective consumers while their owners were potential buyers. Moreover,

\footnotetext{
${ }^{42}$ Stanley L. Engerman, "Economic growth of colonial North America," in John J. McCusker and Kenneth Morgan, eds., The Early Modern Atlantic Economy (Cambridge: Cambridge University Press, 2000), 236, Table 9.1A. The table lists only "black" populations. Here, it is assumed a majority of this West Indian black population were slaves. According to O'Shaughnessy, "free people of color represented less than 2 percent of the total population of the islands” during the mid-to-late eighteenth century. O’Shaughnessy, An Empire Divided, 29. For more on the expansion of the French West Indian islands, see W.J. Eccles, The French in North America, 15001783, revised edition, (East Lansing, Michigan: Michigan State University Press, 1998), esp. ch. 6, "The Slave Colonies, 1683-1748;” and Blackburn, The Making of New World Slavery, 277-306, 431-456.
} 
in terms of total land mass, the surface area on French islands available for agricultural production and settlement was twice that of the British islands. ${ }^{43}$ For New England sellers, these factors meant French markets had the potential to produce even more sugar and import additional slaves above and beyond Great Britain’s capacity. Entrepreneurial Yankees able to secure connections and establish networks of trust early on would be all but guaranteed attractive future returns from such burgeoning French markets.

In addition to these comparative advantages, fish was a perishable commodity that required a buyer willing to purchase an entire shipment, or several different buyers near one another so as to avoid additional transportation and time in the ship’s hold. It was a fundamental fact that the British islands could not purchase all of New England's annual fish exports. In 1763, Payne and the Society for the Encouragement of Trade and Commerce collected trade data from New England fishing ports in order to lobby against passage of the Sugar Act in Parliament. Payne and the Society calculated that British plantations could only purchase 1/3 of New England's dried cod exports to the West Indies. ${ }^{44}$ Whether a merchant purchased dried cod from other merchants and paid shippers to freight the haul to the West Indies, or he outfitted his own schooner, hired a crew, dried the catch, and then paid the men to transport the fish south, in

${ }^{43}$ Blackburn, The Making of New World Slavery, 432, 438-439.

44 "In the Preamble to a late Act of Parliament," 1764, attributed to Edward Payne, Ezekiel Price Papers, 17541785, MHS. Payne estimated that $60 \%$ of all the fish exported from New England went to the West Indies. The other $40 \%$ "is sent to Spain, Portugal \& Italy, \& the net proceeds of the Fish \& Freight, deducting the cost of a load of Salt, is remitted to G[reat] B[ritain].” Of the $60 \%$, Payne calculated $20 \%$ was sold to British Islands and $40 \%$ was sold outside the empire. Also, see the sworn testimonies of Marblehead fish merchants Robert Hooper and Jeremiah Lee, given before Lieutenant Governor Thomas Hutchinson in 1764. Hooper and Lee testified: "We are not only largely concerned in the owning of Vessels, \& employing the People in the Fishery, but annually ship large Quantities both to Europe and the West Indies on our own Accounts; and we have supplied Barbados, Antigua, St. Kitts, and all the English Windward Islands, as well as Jamaica with large Quantities whereby we have a considerable knowledge of the Quantities these Islands consume; and according to our best Judgment all the English West India Islands do not consume more than 1/3 the Quantity of West India Fish we catch or take, and were it not for the Advantage of supplying the foreign Islands with said Fish we could not have a Market for more than 1/3 of it, and the other 2/3 must perish on our Hands, and the Fishery entirely drop.” Hooper Fisheries Statement, 10 January 1764, Misc. Bd. Manuscripts, 1761-1765, MHS. 
either case slowly rotting cargoes of cod represented considerable, and risky, investments. Fish merchants would have taken a large loss on every shipment to the West Indies in the second half of the eighteenth century if they restricted their sales to $1 / 3$ of their dried cod and then allowed the rest of the cargo to spoil. Because even dried, salted cod went bad given enough time, a full 2/3 of New England's cod exports to the West Indies had to be sold to British competitors or else rot. This fish, Payne wrote, was vended "to the French \& other Foreign Islands.” ${ }^{5}$ St. Eustatius, the "Golden Rock" of the West Indies, was a popular Dutch free port, and the Dutch welcomed additional business. $^{46}$ But, for their part, wealthy British planters were not content to sit quietly and watch New Englanders sail away with fish and credit to "French \& other Foreign Islands.”

\subsection{THE POLITICAL RAMIFICATIONS OF NEW ENGLAND'S WEST INDIAN EXPANSION}

Those concerned in British West Indian sugar production were well positioned to defend their economic interests at the imperial level. British sugar planters were counted among the wealthiest subjects in the empire. Many were absentee landlords who chose to live in England. They purchased real estate in many different parts of England, building townhouses in cites and great houses with formal gardens in the countryside. Such land ownership and extreme wealth provided planters with direct access to political power. They also sought - and won - election to

${ }^{45}$ Ibid.

${ }^{46}$ Benjamin W. Labaree, William M. Fowler, Edward W. Sloan, John B. Hattendorf, Jeffrey J. Safford, and Andrew W. German, America and the Sea: A Maritime History (Mystic, Conn.: Mystic Seaport Museum Publications, 1998), 134-135; Ronald Hurst, The Golden Rock: An Episode of the American War of Independence, 1775-1783 (Annapolis, MD: Naval Institute Press, 1996); Barbara W. Tuchman, The First Salute: A View of the American Revolution (New York: Alfred A. Knopf, 1988); and J. Franklin Jameson, "St. Eustatius in the American Revolution,” The American Historical Review, Vol. 8, No. 4 (July, 1903), 683-708. 
the House of Commons. Planters were also three times as likely as anyone from North America to be given a title to nobility between 1701-1776, and they frequently intermarried with traditional English peers. This meant that they gained considerable power in the House of Lords. Over the course of the eighteenth century, there were between 40-60 members of Parliament at any given time who were either sugar planters themselves, or who were financially involved in the West Indian plantations. William Beckford, for example, was born in Jamaica, the largest source of sugar in the eighteenth century British Empire, and he inherited his father's sugar plantation. Beckford grew up and lived in London, where he was twice lord mayor, in 1762-63 and 1769-70. He was a member of the House of Commons between 1747 and 1770, and he was a close personal friend of William Pitt the Elder. Among the seventy-five members of the Board of Trade, a group that advised the crown on colonial affairs, only five had ties to the Western Hemisphere between its genesis in 1696 and the beginning of the American Revolution, but four of these five were commercially connected to the West Indies. ${ }^{47}$ Simply put, the sugar industry had powerful advocates at the helm of the British ship of state. Indeed, Lord North, Great Britain's prime minister during the imperial crisis and a man not easily controlled, referred to the West Indian sugar planters as "the only masters he ever had.”48

Wealthy sugar planters could also afford to hire a group of full-time professional advocates, or agents, to lobby Parliament on their behalf. By 1774, the small islands in the West

\footnotetext{
${ }^{47}$ Hornsby, British Atlantic, American Frontier, 46-47, 60; O’Shaughnessy, An Empire Divided, 14-17, esp. Table 1; and Jacob M. Price, "Who Cared about the Colonies? The Impact of the Thirteen Colonies on British Society and Politics, circa 1714-1775," in Bernard Bailyn and Philip D. Morgan, eds., Strangers Within the Realm: Cultural Margins of the First British Empire (Chapel Hill: The University of North Carolina Press, 1991), 399-400. For an alternative view of colonial-core relations that stresses the role informal voluntary associations such as churches and coffee houses played in bringing the interests of colonial merchants in line with imperial policy, see Olson, Making the Empire Work. Olson does not investigate the colonial fishing industry.

${ }^{48}$ Herald: A Gazette for the Country, August 23, 1797, cited in Alice B. Keith, "Relaxations in the British Restrictions on the American Trade with the British West Indies, 1783-1802," Journal of Modern History, Vol. 20, No. 1 (March, 1948), 16.
} 
Atlantic maintained ten permanent agents in London whose sole purpose was to promote and defend the interests of the British sugar industry. One of these men, Stephen Fuller, worked in this capacity for thirty years between 1764-94. The agents were supported in their work by the London-based Society of West India Merchants. Because most of the sugar produced in the British West Indies was consumed in England during the eighteenth century, London sugar buyers such as Richard Neave and Beeston Long, chairmen of the Society and governors of the Bank of England, were very interested in any effort to lobby Parliament on behalf of the sugar industry. ${ }^{49}$

New England fish merchants did not have the resources of the planters or equal access to political power. Yankee merchants by and large did not own real estate in England. They did not control many seats in Parliament. Nor did they have ties to the Bank of England. Of the hundreds of men who were members of the House of Commons between 1754 and 1774, only two individuals, John Tomlinson and Barlow Trecothick received money to represent New England. They were paid to act for New Hampshire. Five merchants who were members of the Commons maintained casual commercial ties to New England. ${ }^{50}$ None of these men were willing to sacrifice their political positions for the colonial fishing industry. Therefore, New England fish merchants were forced by necessity to rely upon a small number of agents to lobby in favor of their interests. By 1774, there were just three active North American agents, compared to ten from the West Indies. Only two of these three, William Bollan and Arthur Lee, were full-time advocates for New England interests. Ben Franklin, the third colonial agent,

\footnotetext{
${ }^{49}$ O'Shaughnessy, An Empire Divided, 15-16, 60-62.

${ }^{50}$ Price, "Who Cared about the Colonies?” 403-405.
} 
represented Pennsylvania, Georgia, New Jersey, and Massachusetts, and could not be expected to devote much time to the fishing industry. ${ }^{51}$

Fish was also not as valuable as sugar to the British Empire, which further restricted colonial fish merchants' ability to effectively lobby Parliament. The total value of British West Indian sugar, rum, and molasses exported between 1768-72 was £3,910,600. The equivalent figure for New England fish was $£ 152,155 .^{52}$ William Bollan, the agent for Massachusetts for more than twenty-five years leading up to the Revolution, referred to lobbying Parliament as driving "about the wheels of Business,” which took “a considerable Expense.” Indeed, at one point Massachusetts merchants paid Bollan £2,585 for four years of "attending the negotiation of Business here” in London. Rotating the "wheels of Business” in the eighteenth century, it seems, required considerable sums of money in order to grease "negotiations" with members of Parliament. ${ }^{53}$ The fact that sugar elites had more grease, and more mechanics to lubricate the system, meant the New England fish lobby was at a decided disadvantage in any attempt to rotate commercial wheels in a favorable direction.

British West Indian planters thus operated from a position of great strength in the imperial contest for Parliamentary affection in the eighteenth century, and whenever their interests opposed those of the New England fish merchants, they usually came out on top. To be

\footnotetext{
${ }^{51}$ Sosin, Agents and Merchants, 176-177. Sosin acknowledges the fact that technically there were five colonial agents, including Edmund Burke (New York) and Charles Garth (South Carolina). However, Sosin maintains that both of these men put their duties as MPs above their roles as agents. The number of colonial North American agents in London seems to have remained constant over the course of the eighteenth century. For example, there were five of these agents in 1731: Francis Wilks served as agent for Massachusetts and Connecticut; Richard Partridge served as agent for New Jersey; Samuel Wragg served as agents for South Carolina; Ferdinando John Paris served as agent for Pennsylvania; and Isham Randolph served as agent for Virginia. See, PDBP, Vol. 4, 103-120. For an argument that the American colonies were able to influence colonial policy until the end of the Seven Years' War, see Olson, Making the Empire Work. Olson does not systematically investigate the fishing industry and the Molasses Act, however.

${ }^{52}$ McCusker and Menard, The Economy of British America, 1607-1789, 160, Table 7.3,

${ }^{53}$ Letter from William Bollan to the Secretary of the Massachusetts General Court, dated Pall-mall, April 19, 1754, Ezekiel Price Papers, 1754-1785, MHS.
} 
sure, over the course of the century the British state ratified certain treaties that benefited the New England fishing industry, such as the Treaty of Utrecht in 1713 and the Treaty of Paris in 1763. These settlements severely limited the ability of the French to compete in the Atlantic cod trade, and effectively expanded the operations of colonial British fishermen, both in terms of fishing waters and Atlantic markets. ${ }^{54}$ Nevertheless, the West Indies enjoyed a longer and stronger tradition of support from the British state. In the Treaty of Breda in 1667, Charles II ceded Nova Scotia to the French in exchange for Antigua, Montserrat, and the rest of St. Christopher's Island. Colonists in Massachusetts protested, citing the threat nearby French competitors posed to their fishing operations. Yet, in the end a premium was placed on sugar production because of the wealth it generated. ${ }^{55}$ Between the Treaty of Breda and the American Revolution, the British state established a series of prohibitive duties on foreign sugars, guaranteeing planters a permanent monopoly in the home market. In 1739, Parliament granted sugar, an enumerated article, an exemption from the seventeenth century Navigation Acts and allowed it to be traded directly to foreign ports in vessels built in and sailing from Great Britain. $^{56}$ In 1742, this trade privilege was extended to colonial-built vessels. ${ }^{57}$ Six years later, an act exempted the British West Indies from naval impressment. The same act did not mention the New England colonies despite their appeals for formal renewal of the $6^{\text {th }}$ of Anne prohibition against impressment in the colonies. ${ }^{58}$ In this manner, the British state supported the sugar planters and encouraged the sugar industry.

\footnotetext{
${ }^{54}$ For more on the impact the two treaties had on cod fishing around Newfoundland, see Innis, The Codfisheries, 138, 179-180.

${ }^{55}$ Bailyn, The New England Merchants in the Seventeenth Century, 128.

${ }^{56}$ McCusker and Menard, The Economy of British America, 1607-1789, 162; and Andrews, “Anglo-French Commercial Rivalry, 1700-1750: The Western Phase, II,” 777.

${ }^{57}$ Andrews, “Anglo-French Commercial Rivalry, 1700-1750: The Western Phase, II,” 778.

${ }^{58}$ Richard B. Morris, Government and Labor In Early America (New York: Harper \& Row, Publishers, 1946), 276.
} 
In the first half of the eighteenth century, when French sugar prices first gained their comparative advantage, the British planters were upset that New England fish merchants were vending their goods among the French islands and purchasing their chief competitor's sugar products. In 1701, Governor Codrington of the Leeward Islands recommended a Parliamentary act prohibiting New Englanders from shipping fish to the French West Indies. ${ }^{59}$ Henry Worsley, the governor of Barbados, one of the most productive sugar islands, complained to the Board of Trade in 1723 that Yankees were exchanging fish for French molasses to feed their expanding number of distilleries. ${ }^{60}$ Governors such as Worsley and Codrington even attempted to seize and condemn colonial vessels found to be trading with French islands. ${ }^{61}$ It did not matter that such trade was perfectly legal as long as it was conducted in British vessels. ${ }^{62}$

Partly because of the kinship and business ties between the planters and Parliamentarians, and because West Indian exports were worth more on a balance sheet than all of the North American mainland colonies' exports combined, the British state passed the Molasses Act in 1733 despite opposition from the New England fishing interests. ${ }^{63}$ The "act for

${ }^{59}$ Andrews, “Anglo-French Commercial Rivalry, 1700-1750: The Western Phase, I,” 549-550.

${ }^{60}$ Governor Worsley to the Board of Trade, March 26, 1723, Calendar of State Papers, Colonial Series, America and the West Indies, 1721-23, No. 486.

${ }^{61}$ Andrews, “Anglo-French Commercial Rivalry, 1700-1750: The Western Phase, II,” 764.

${ }^{62}$ Oliver M. Dickerson, The Navigation Acts and the American Revolution (Philadelphia: University of Pennsylvania Press, 1954), 83.

${ }^{63}$ PDBP, Vol. 4, 162-163, esp. footnotes 82-86. Yankee merchants and their agent protested that the markets among the British islands were too small to consume all of the fish sent south, and that these same markets could not provide enough supplies to fill holds on the return trip north. For more arguments against the Act, see The Case of the Provinces of the Massachusetts Bay and New Hampshire and the Colonies of Rhode Island with Providence Plantations, and Connecticut in New England, and the Province of New Jersey, with respect to the Bill now depending in the Honourable House of Commons, entitled a Bill for the better securing and encouraging the Trade of His Majesty's Sugar Colonies in America (London: 1731); and The Case of the British Northern Colonies (London: 1731). For arguments in favor of the Act, see Observations on the Case of the British Northern Colonies (London: 1731); and The Importance of the British Sugar Plantations in America to this Kingdom, with the State of their Trade and Methods for Improving it (London: 1731). For more on the Molasses Act, see Richard B. Sheridan, "The Molasses Act and the Market Strategy of the British Sugar Planters," Journal of Economic History, Vol. 17, No. 1 (March, 1957), 62-83. The West Indian sugar interests had actually gotten a similar bill through the House of Commons in 1731, only to have it rejected by the Lords. Charles McLean Andrews has argued that because British planters and their friends failed to get their protective legislation passed on the first attempt, Parliament did not favor 
the better securing and encouraging the trade of his Majesty's sugar colonies in America” set prohibitive duties on foreign sugar (“Five Shillings per Hundred weight”), molasses (“Six pence per Gallon”), and rum (“Nine pence a Gallon”), which, if enforced and obeyed, would have effectively stopped New England trade with the French West Indies. ${ }^{64}$ In the preamble to the Act, Parliament justified its passage in the following manner: "Whereas the welfare \& prosperity of your Majesty's sugar colonies in America are of the greatest consequence and importance to the trade, navigation and strength of this kingdom; and whereas the planters of the said sugar colonies, have of late years, fallen under such great discouragements that they are unable to improve or carry on the Sugar Trade, upon an equal footing with the Foreign Sugar colonies, without some advantage and relief given to them from Great Britain.”65 The Act could have given British planters a second monopoly, this time on the colonial North American markets. It was not enforced, however, and fish merchants found various ways around the letter of the law. ${ }^{66}$ Yet, the law effectively turned legitimate colonial merchants into smugglers, and continual pressure from the sugar interests resulted in the renewal of the Act every five years until 1764.

New England fish merchants and sugar planters continued to lobby against one another after 1733. Not satisfied with the Molasses Act, the sugar lobby demanded stricter enforcement almost from the moment it was enacted. The Yankees, in contrast, did not want any restriction on their ability to sell fish. In 1754, Bollan wrote to the Massachusetts General Court to inform

their interests. He also cites the return of Guadeloupe to France in 1763 as further evidence of Parliament's disfavor. Andrews, “Anglo-French Commercial Rivalry, 1700-1750: The Western Phase, II,” 772-773. I argue that comparatively, Parliament greatly favored the sugar interests over the New England fishing interests.

${ }^{64}$ For a copy of the act, see New England Weekly Journal, December 31, 1733.

65 The 1733 Act was republished in The New-Hampshire Gazette, and Historical Chronicle, January $29,1768$.

${ }^{66}$ For more on the extent to which the Act was evaded, see Barrow, Trade and Empire, 134-143; and Dickerson, The Navigation Acts and the American Revolution, 66-69, 82-87. In 1763, a Boston newspaper writer stated: "The sugar act [a.k.a. the Molasses Act] has from its first publication been adjudged so unnatural, that hardly any attempts have been made to carry it into execution.” Boston Evening Post, November 21, 1763. Dickerson has gone too far in arguing that, because of the widespread colonial evasion, neither the Molasses Act nor the Sugar Act had much of an impact in terms of motivating colonists to resist British authority. 
its merchant members that the "the West Indians," whom he referred to as "the adversaries of the Province," were "indefatigable, sparing no pains or Expense of any kind, but use their utmost Endeavor in every shape to carry their point.” The representative of the colonial fishing industry was optimistic at this time and expected a resolution to the Act that would at last result in New England's favor: "we have thus far been able to defeat all their late Attempts, and as we have from time to time gained Ground of them, there is in my humble opinion, the greatest reason to go on, and prepare for the approaching and final Trial and Determination of this Matter.”67 However, renewed conflict with the French and the ensuing Seven Years' War delayed the "final Trial” Bollan anxiously anticipated. The war also altered the outcome Bollan expected in ways he could not have foreseen.

The Seven Years' War was one of the first truly global conflicts, and it stretched the limits of Great Britain’s military and fiscal abilities. ${ }^{68}$ The war embroiled European powers in combat in the Atlantic, Indian, and Pacific Oceans. The British government borrowed enormous sums of money to equip and provision troops, to purchase and maintain weaponry, and to build and outfit warships. Britannia emerged victorious over seas as well as lands, but it cost the nation $£ 160$ million just to fight the war - twice the gross national product. Britain was just wealthy enough to pay its creditors $£ 14$ million at the end of the war, leaving a huge debt for the future. Maintaining garrisons in North America alone cost $£ 200,000$ a year during the 1760 s. $^{69}$

\footnotetext{
${ }^{67}$ Letter from William Bollan to the Secretary of the Massachusetts General Court, dated Pall-mall, April 19, 1754, Ezekiel Price Papers, 1754-1785, MHS.

${ }^{68}$ According to Jonathan Israel, the Second Anglo-Dutch War (1664-1667) was a global war. Jonathan I. Israel, The Dutch Republic: Its Rise, Greatness, and Fall, 1477-1806, $4^{\text {th }}$ ed., (Oxford, England: Oxford University Press, 1998), 766-774.

${ }^{69}$ Fred Anderson, Crucible of War: The Seven Years' War and the Face of Empire in British North America, 1754-1766 (New York: Vintage Books, 2000), 562; Nancy F. Koehn, The Power of Commerce: Economy and Governance in the First British Empire (Ithaca, NY: Cornell University Press, 1994), 5, 12; and Shy, Toward Lexington, 241.
} 
The immense war debt, coupled with additional military expenditures carried over from the war, left the heads of the British state looking for ways to raise additional revenue.

In 1763, Parliament debated whether or not to make the Molasses Act permanent, and what, if any, alterations needed to be made to the Act to give it teeth. In many ways, these Parliamentary debates represented a continuation of the commercial rivalry that existed between the New England fish merchants and the sugar interests, which included the planters themselves, their lobbyists, and the planters' friends and relatives in Parliament, since the French lowered their West Indian prices. Once more, those representing the fishing industry argued that British West Indian markets could not consume all of New England's fish, nor could British planters provide enough sugar products in exchange. The shrewd Yankees reminded Parliament that the profits from their trade with the French ended up being used in exchange for manufactured goods from Great Britain. Thus, restricting New Englanders' profits would ultimately hurt domestic industries in England. The fish merchants also tried to convince Parliamentarians that colonial fishing vessels and maritime workers contributed to the "nursery" for naval seamen, and therefore the encouragement of their fisheries was closely linked to matters of military preparedness and state power. ${ }^{70}$

Meanwhile, in Boston the Society for the Encouragement of Trade and Commerce had been busy preparing for the 1763 debate. Members of the Society corresponded with "Merchants of Salem, Marblehead, and Plymouth,” convened "diverse meetings of committees

\footnotetext{
70 "In the Preamble to a late Act of Parliament," 1764, attributed to Edward Payne, Ezekiel Price Papers, 17541785, MHS. Also see, Reasons Against the Renewal of the Sugar Act (Boston, 1764), Early American Imprints, Series I: Evans \#9812. As early as 1698, the English pamphlet writer Sir Josiah Child observed: "I must confess that though we [merchants in England] lose by their [New England merchants] unlimited trade with our foreign plantations, yet we are very great gainers by their direct trade to and from Old England. Our yearly exportations of English manufactures, malt and other goods from hence thither amounting in my opinion to ten times the value of what is imported from thence." Sir Josiah Child, A new discourse of trade wherein is recommended several weighty points relating to companies of merchants... (London, 1698).
} 
from the several Towns," and designed "Reasons against the Renewal of the Sugar Act," which were "presented to the General Court...were adopted by them, and transmitted to their agent" in London. In this manner, the Society played an important role in facilitating the colony's lobby efforts. At great expense, the Society "also sent copies [of their "Reasons"], fairly wrote, to the Merchants of six of the Neighboring Governments, and afterwards 250 printed copies to the Principal Merchants in London., ${ }^{71}$

The fish merchants also made public their grievances in a Boston newspaper. In a series of letters, a colonial dissenter writing under the pseudonym "Baron de Montesquieu," the French Enlightenment figure, laid out all of the arguments that the Massachusetts' colonial agent had been putting before Parliament. In addition, "Montesquieu" reminded colonists that "The seasons for curing fish are some years so unfavorable, that the greatest part of what is caught is only fit for the West India market....The chief part of this fish we depend on the foreign sugar colonies to take off our hands. The only pay they have to give therefore is sugar and molasses; an article of great use to fishermen.” The dissenter who dared not publish his real name believed “A reformation [in trade regulations] is become necessary. But should such restraints take place as to discourage the trade, and destroy the fishery of the northern colonies; Great Britain, instead of benefiting itself by its conquests [i.e. the Seven Years' War], has only added a load which it must at length sink under." In short, "Montesquieu” argued that a permanent tax on foreign sugars would disrupt the trade in refuse grades of dried cod that were shipped to the West Indies. If this trade was disrupted, he reasoned, then the conquest of Canada and Newfoundland had been for naught. "Montesquieu" attributed the existence of taxes on foreign sugars, and the plans to make them permanent and more rigidly enforced, to the powerful British sugar interests,

\footnotetext{
${ }^{71}$ Letter from Thomas Gray and Edward Payne “To the Members of the Society for Encouraging Trade \& Commerce,” dated Boston, January, 1766, Ezekiel Price Papers, 1754-1785, MHS.
} 
or "To the aggrandizement of the planters of our sugar colonies; who, notwithstanding they have become so opulent, that upwards of forty of them have seats in the House of Commons, and numbers have formed alliances with some of the noblest families in the kingdom, do yet complain for want of further encouragement. Oh fatal Policy! Error irretrievable!”72

Despite fish merchants' best efforts to publicize their arguments at home and abroad, Parliament ultimately found in favor of the sugar interests, just as they had done in 1733 and on other occasions. The Sugar Act, also known as the Revenue Act, became the law of the empire in 1764. It levied a tax of "One pound, two shillings, over and above all other duties imposed by any former act of parliament" on foreign white sugars imported into the colonies. The importation of foreign rum was forbidden, giving West Indian planters a monopoly on the rum trade with North American. To be sure, Parliament reduced the incentive to smuggle by lowering the duty on foreign molasses to "three pence." Such a move can be construed as a concession to the New England fishing interests. Yet, New Englanders were not satisfied as they desired no tax whatsoever. Moreover, the duties on sugar and molasses were made "perpetual" starting in September, $1764 .^{73}$

The Sugar Act did not simply restrict North American trade to the West Indies. In order to prevent direct trade with French possessions anywhere in the Atlantic, and thereby restrict North American access to inexpensive sugar products, the Sugar Act expressly forbade colonial trade with French territories in the North Atlantic. As part of the 1763 peace treaty ending the Seven Years' War, France retained only a few islands off the south coast of Newfoundland (St.

\footnotetext{
72 Boston Evening Post, November 21, 1763; and Boston Evening Post, November 28, 1763.

${ }^{73}$ PDBP, Vol. 1, 492-494; Anno regni Georgi III... (London, 1764), Early American Imprints, Series I: Evans \#41449; and Boston Evening Post, June 25, 1764.
} 
Pierre and Miquelon) and fishing rights to the western shoreline of the land of cod. ${ }^{74}$ However, these islands were important to New England commerce, and they had been for some time. As early as 1684 New Englanders were supplying French fishermen and traders at St. Pierre with dried cod, rum, and molasses in exchange for West Indian goods, European manufactured products, and lines of credit. ${ }^{75}$ Thus, it was no small matter that the 1764 act prohibited direct trade with "the subjects of the crown of France in the islands of Saint Pierre and Miquelon.”76

In order to give the act teeth, Parliament restructured custom collection and gave new orders to the Royal Navy. Absentee customs collectors, who had been collecting nothing but their stipends, were ordered to return to their posts. Officials who did not comply were removed. Informants who aided custom collection were given greater rewards. Customs officials who cooperated with smugglers were threatened with greater punishment. More customs offices were created and additional manpower was added. New certificates signed by justices of the peace designating the origin and quantity of all sugar products on board were required of traders at the port of departure and at the port of entry. Shippers were required to post additional bonds as assurance their goods would be landed only in British ports. Ships leaving colonial ports also had to have a "cocket," or cargo list. This list could only be obtained from the customs house, and it catalogued which goods were subject to import and export duties, and which duties had

\footnotetext{
${ }^{74}$ In article four of the treaty, France ceded Canada, Acadia, and Nova Scotia to Britain. Article five stipulated that "the subjects of France shall have the liberty of fishing and drying on a part of the coasts of the island of Newfoundland, such as is specified in the XIIIth Article of the Treaty of Utrecht [i.e., from Bonavista to Point Riche]." Article six of the treaty stipulated "the King of Great Britain cedes the Island of St. Pierre and Miquelon, in full right, to his Most Christian Majesty, to serve as a shelter for the French fishermen. And his said Most Christian Majesty engages not to fortify the said islands; to erect no buildings upon them, but merely for the convenience of the fishery; and to keep upon them a guard of fifty men only for the police.” For copies of this peace treaty, see The Providence Gazette; And Country Journal, May 21, 1763; The Newport Mercury, May 23, 1763; and The New-Hampshire Gazette, May 27, 1763.

${ }^{75}$ Innis, The Codfisheries, 122.

${ }^{76}$ Anno regni Georgi III... (London, 1764), Early American Imprints, Series I: Evans \#41449, 17. Lord Grenville, the head of the Treasury Department and the driving force behind efforts to reform colonial revenue collection, argued in 1764 that such a prohibition was necessary "to take care that all illicit commerce be stopped with St. Pierre and Miquelon.” PDBP, Vol. 1, 492.
} 
been paid. Even sailor's private ventures were required by law to be included on the cocket, and were subject to duties. Royal governors were directly ordered to be more vigilant in the collection of His Majesty's customs. The patrols of the Royal Navy were more active and more numerous. Naval officers viewed themselves as enforcers of martial law on the high seas. For example, any vessel caught within two leagues of a British port without a cocket was subject to seizure by the Navy. These seizures were prosecuted in a special Vice-Admiralty court established in Halifax, Nova Scotia for the express purpose of trying violators of the Sugar Act. ${ }^{77}$

The Navy placed special emphasis on enforcing the Sugar Act in the North Atlantic, and most of its warships were positioned along the Northwest Atlantic littoral between Massachusetts and Newfoundland. Neil R. Stout, the foremost authority on the naval enforcement of British colonial policy, maintains that the concentration of military force was primarily due to two factors: Halifax represented "the principal naval base" and "the only royal dockyard" in North America, and the British wanted to "overawe the Canadians and impress France."78 Certainly, these factors cannot be ignored. However, New England merchants were the principal violators of the Sugar Act and cod was the principal commodity used in exchange for French contraband. Thus, the British Navy positioned their forces to cut-off illicit trade at its source as well as to intimidate the French. Commodore Hugh Palliser, the naval officer in charge of a portion of the British North Atlantic fleet and the royal governor of Newfoundland between 1764-1769, ordered his squadron to seize "all New England Vessels" found prosecuting such "Illicit

\footnotetext{
${ }^{77}$ Neil R. Stout, The Royal Navy In America, 1760-1775: A Study of Enforcement of British Colonial Policy in the Era of the American Revolution (Annapolis, Maryland: The United States Naval Institute, 1973), 25-38, 55, 5690, 166; Leonard Woods Labaree, ed., Royal Instructions to British Governors, 1670-1776, 2 Vols., (New York: Octagon Books, Inc., 1967), Vol. 2, 766-767, 780; and Carl Ubbelohde, The Vice-Admiralty Courts and the American Revolution (Chapel Hill, University of North Carolina Press, 1960), 49-54, 101-103.

${ }^{78}$ Stout, The Royal Navy In America, 1760-1775, 57.
} 
Trade.,"79 In 1765, Palliser reported to the Board of Trade: "Great Numbers of New England Vessels are also become Fishers for the French at those Islands, and Engaged in Trade with them for French Goods and Manufactories; however, I believe they will not pursue it so Eagerly as they had begun, for we have taken \& Confiscated Five of them.." ${ }^{, 0}$ According to contemporary estimates, the cost for purchasing a single deep sea fishing schooner and outfitting a crew for one year was $£ 1,135 .^{81}$ In $1755, £ 1,135$ sterling was equivalent to $\$ 131,528.34$ in year 2000 U.S. dollars. ${ }^{82}$ Thus, Palliser's capture of five of these vessels in 1765 corresponds to a financial loss of over $\$ 657,000$ in 2000 U.S. dollars. That same year, Boston fish merchant John Rowe recorded in his diary: "Mr. [Elbridge] Gerry [a Marblehead fish merchant] came to Town \& brought an account of the Niger, Man of War, taking three Schooners out of the Harbor of St. Pierre's, one belonging to his Father \& two of Epps Sargent [a Gloucester merchant]." ${ }^{83}$ One year later, a colonial newspaper reported: "They write from Newfoundland, that several New England sloops have been seized by his Majesty's ships of war at Cape Breton, for smuggling with the French, and selling them large quantities of ready cured fish....by means of which several fishermen from Rochelle and Bordeaux got loaded in a few days, and had actually sailed home with cargoes of fish ready cured for the Mediterranean markets.” ${ }^{84}$ In this manner, the

\footnotetext{
${ }^{79}$ Palliser's Order “to Mr. Nicholas Gill, Naval Officer at St. Johns, authorizing him to seize Illicit Traders,” St. Johns, November 4, 1764, Colonial Secretary Letterbooks, 1752-1765, MUMHA, 276-277.

${ }^{80}$ Letter from Palliser to the Board of Trade \& Plantations in London, dated St. John's, Newfoundland, October 30, 1765, NA CO 194/16/170-174. MHS.

81 “Calculations respecting outfits of a Fishing vessel,” December 1763, Ezekiel Price Papers, 1754-1785,

${ }^{82}$ John J. McCusker, How Much Is That In Real Money? A Historical Commodity Price Index for Use as a Deflator of Money Values in the Economy of the United States, $2^{\text {nd }}$ ed., (Worcester, Massachusetts: American Antiquarian Society, 2001), 35-36.

${ }^{83}$ Anne Rowe Cunningham, ed., Letters and diary of John Rowe: Boston merchant, 1759-1762, 1764-1779 (Boston: W.B. Clarke Co., 1903), 87.

${ }^{84}$ Georgia Gazette, September 3, 1766.
} 
Sugar Act, which was meant to encourage the British West Indian islands, came at the expense of New England commerce.

The British state justified the new act and the stricter enforcement measures around the Atlantic Ocean in two ways. First, Parliament stated that the "Act for the better securing and encouraging the trade of his Majesty's sugar colonies...should be altered, enforced, and made more effectual.” This justification indicated Parliamentary preference for the sugar industry, as making the Molasses Act "more effectual" could only restrict trade to the British West Indian islands. Second, Parliament stated that the Sugar Act was meant to raise revenue "towards defraying the necessary expenses of defending, protecting, and securing the British colonies and plantations in America." ${ }^{85}$ Since 1733, New Englanders had made customs avoidance an art form, and government revenue streams from this sector had slowed to a trickle as a result. Once Seven Years' War debts began coming due, even those Parliamentarians who had given Bollan a glimmer of hope before the outbreak of the global conflict were now less inclined to remove the taxes on foreign sugar products. After the war, Parliament was even more resolved to defend the sugar industry and draw revenue from the colonies.

Royal governors and elected assemblies in the British West Indies responded to the Sugar Act in various ways. Antiguans punished anyone caught smuggling French sugar into the British Empire with exile in $1764 .{ }^{86}$ At this time, the governor of Guadeloupe prohibited "all ships from coming to this Colony unless they are furnished with a written permission of the Intendant” in order "to put a stop to Contraband Dealings which become every Day more frequent and more

\footnotetext{
${ }^{85}$ Boston Evening Post, June 25, 1764.

${ }^{86}$ O’Shaughnessy, An Empire Divided, 61.
} 
easy." Punishment for violating this regulation was "Confiscation of the Ship and Cargo, of a Fine of 3000 Livres to the Kings Use, and of a Years Imprisonment.”87

Colonists in New England considered the Sugar Act the latest in a long series of examples of favoring sugar over fish. They reacted to the legislation with bitterness and frustration. One colonial critic published his grievances under the nom de plume "Americanus." This writer denounced the Act, as its prohibitive duties on foreign sugar and molasses and its ban on foreign rum effectively denied merchants in "the New England fishery" the "disposal of [refuse, or Jamaican, grades] to the French and Dutch.” Because of the loss of these markets, "difficulties fell upon the New England fishery, [and] in the chief fishing town (Marblehead) the vessels were reduced one half in their number." “All the merchants” in New England, he wrote, believed "that the continuance of the duty on molasses, with other duties imposed by the said act [the Sugar Act], will inevitably destroy" the "fishing trade." “Americanus" further estimated that New Englanders only imported “one eight part” of their molasses from the British West Indies because of high prices. Thus, another result of the Act was to limit the amount of West India goods "had by the fishermen." 88

Colonists blamed the British West Indian planters for the restrictions placed on the fishing industry, trade, and regional consumption. In a "Statement of the Trade and Fisheries of Massachusetts,” written in 1764, fish merchants in Boston stated their belief that the planters had, "with no other view than to enrich themselves," forced "the northern Colonies to take their whole supply from them; and they still endeavor the continuance of it under a pretence, that they can supply Great Britain and all her Colonies with West India goods, which is perfectly

\footnotetext{
87 "Regulations published by the Governor of Guadeloupe \& other Islands relative to trade,” August 18, 1763, MSA Collections, Vol. 66, Maritime, 1759-1775, 237-240.

${ }^{88}$ Boston Evening Post, January 20, 1766.
} 
chimerical." ${ }^{89}$ A newspaper in Providence, Rhode Island mourned the fact that "the Continent must henceforth move in the wake of the sugar planters of the British Empire.”90

Whiggish Parliamentarians in London agreed with colonists that the sugar interests had won the day. Edmund Burke, the foremost opposition member of Parliament in the 1760s, stated his belief that the Sugar Act was a deliberate attempt by corrupt heads of state to generate revenue; to provide planters with a monopoly on North American trade; and to enforce this monopoly with the Royal Navy. The Act, in Burke's words, represented "a revenue not substantiated in place of, but superadded to a monopoly, which monopoly was enforced at the same time with additional strictness, and the execution put into military hands.”91

Some frustrated colonists continued to work within the system to promote change. In 1765, Massachusetts petitioned Parliament "for the repeal of the Sugar Act." This petition maintained "that the importation of foreign molasses into this province in particular, is of the greatest importance.” The colonists believed the tax on sugar and molasses constituted a "prohibition" on the trade. They noted that the importance of their ability to import West Indian sugar products "does not arise merely nor principally from the necessity of foreign molasses, in order to its being consumed or distilled within this province." Rather, they maintained "that if the trade for many years carried on for foreign molasses can no longer be continued, a vent cannot be found for more than one half the fish of inferior quality [i.e. refuse grade dried cod], which is caught and cured by the inhabitants of this province; the French permitting no fish to be carried by foreigners to any of their islands, unless it be bartered or exchanged for molasses.” The colonists further argued "that if there be no sale of fish of inferior quality, it will be

${ }^{89}$ Cited in O’Shaughnessy, An Empire Divided, 66.

${ }^{90}$ Providence Gazette and Country Journal, October 27, 1764.

${ }^{91}$ Edmund Burke, "Speech on American Taxation," April 19, 1774, in Edmund Burke on Government Politics and Society, edited by B.W. Hill, (London: Harvester Press, 1975), 125. 
impossible to continue the fishery." The combination cure adopted throughout New England in the eighteenth century made it impossible to catch and cure cod without producing a certain percentage of fish that was not saleable in European markets. If New Englanders could only sell to European markets, then they would have to raise their prices to make up for the loss of the West Indian markets. As a result, "the fish usually sent to Europe will then cost so dear, that the French will be able to undersell the English at all the European markets, and by this means one of the most valuable returns to Great Britain will be utterly lost, \& that great nursery of seamen destroyed." ${ }^{92}$

There is some evidence to suggest that the reaction of the fishing interests changed Parliament's sentiment regarding the Sugar Act. Eventually, the tax on molasses was lowered. In 1766, the duty was lowered to a single penny per gallon, and the fishing industry must get some credit for the reduction. However, as Oliver M. Dickerson points out, the change was the result of the slave traders saying in 1766 that the tax was preventing provisions from reaching the West Indian plantations and restricting the markets for slaves. ${ }^{93}$ This powerful lobby was the main force in reducing the tax on molasses.

Despite the fact that the duty had been lowered to a level at which trade could still continue with French West Indian markets, the tax remained and grated on Yankee sensibilities. New England had grown used to a policy of "salutary neglect" that gave them a degree of free trade. Indeed, this is precisely why Adam Smith supported the colonists in their grievances with the Empire. ${ }^{94}$ Some in the fishing industry thought raising of revenue through taxes without colonists' consent was evidence of a corrupt state attempting to turn its subjects into slaves.

\footnotetext{
${ }^{92}$ Boston Evening Post, March 11, 1765.

${ }_{93}$ Dickerson, The Navigation Acts and the American Revolution, 85-87.

${ }^{94}$ Adam Smith, An Inquiry Into the Nature and Causes of The Wealth of Nations, Max Lerner, ed., (New York: The Modern Library, 1937; orig, pub. in 1776), 616-617.
} 
Benjamin Bangs, a Massachusetts fisherman who had become a wealthy merchant and slave owner through the West Indian trade, recorded his anger and frustration in his personal diary. Following news that the Sugar Act had passed both houses of Parliament, Bangs wrote on October 1, 1764, “Now we may date our slavery. Boston is all in uproar about it. But can’t help it.” A few months later, on December 15, Bangs noted that colonists were beginning to feel more and more like un-free men, constantly policed and watched. In his words, there were "men [of] war in every port guarding us more in peace than in war." ${ }^{95}$ For a slave owner with commercial ties to the West Indies, Parliament seemed to be turning the world upside down by forcing a prosperous merchant into bondage.

Even those colonists predisposed to look on the British state with favor did not like the Sugar Act. John Powell provisioned the British Naval vessels patrolling the New England coast for smugglers in the 1760s. His business ties eventually led him to distance himself from the revolutionary movement. Yet even this Boston merchant wrote in a letter to a friend that news of the Act was "very Alarming To the Colonies." "The [Sugar] Act will prove an unformed monster,” he wrote, “That will Devour all before It \& its makers In The End. The principals of a Commercial Nation is subverted." He further considered the Act "An Unconstitutional Force Laid on the American subjects That must finally End in Riot \& Discord \& be more severely felt In Great Britain Then Even The present Generation can suffer.” Like Bangs, Powell believed Parliament had sent the Royal Navy in greater numbers to their coasts, "Doubling the Cutters," and had added "an Army of Excisemen" in an attempt to restrict colonial freedoms and police trade. Unlike Bangs, who thought the act would convert colonists into slaves, Powell believed it

${ }^{95}$ Benjamin Bangs Diary, 1742-1765, MHS. 
"will oblige us all To hold the plough, the scythe, and Reaping Hook."96 In short, the Bostonian who supplied British Naval vessels saw the act as an attempt to cut-off colonists' access to the sea and maritime ways of life. John Rowe was born in England in 1715 and immigrated to Boston. Like Bangs, he became a very successful merchant and slave owner who dealt in part in fish and the West India trade. Unlike Bangs, Rowe became a Loyalist during the Revolution. On September 29, 1764, the day the provisions of the Sugar Act were to take effect in the colonies, Rowe recorded in his diary "The Black Act takes place this day."97

While Loyalists like Rowe and Powell remained content operating within the British imperial political system, the Sugar Act went a long way toward convincing other colonists who sided more with Bangs that the British imperial political system itself was corrupt and in need of drastic change. At the most basic level, the act restricted colonial fish merchants' access to foreign markets through a prohibitive tax. This meant that a majority of the dried fish processed in New England could not be sold. It also meant that Yankee trade vessels would have to return from the West Indies with only partially filled holds, as the British islands could not produce enough sugar products to meet the needs of England and the colonies. Thus, in the short run, the Act meant increased costs and labor costs for fish merchants. In the long run, these lower profits would have meant greater unemployment in the fishing industry as suggested above.

The act further raised issues of taxation without representation. In 1764, the elected members of the lower house of Massachusetts' colonial legislature concluded with regard to the Sugar Act that "the Power of Taxing" should be "exercised with great Moderation" when applied to "the Dominions who are not represented in Parliament." "For this last is the grand Barrier of British Liberty; which if once broken down, all is lost....a People may be free and tolerably

\footnotetext{
96 “Letter dated Boston, April 9, 1764,” John Powell Letters, 1764-1773, MHS.

${ }^{97}$ Cunningham, ed., Letters and diary of John Rowe, 64-65.
} 
happy without a particular Branch of Trade, but without the Privilege of assessing their own Taxes, they can be neither."98

The Act also brought into stark relief the political corruption that seemed to come from the influence and money of the sugar interests. Some believed that traditional efforts to work within the system and lobby Parliament through colonial agents had failed to bring about real, lasting change because of this corruption. In 1764, the elected members of the lower house of Massachusetts' colonial legislature collectively queried: "If a West-Indian, or any other bye Influence is to govern and supersede our most essential Rights as British Subjects, what will it avail us to make Remonstrances, or the most demonstrable Representations of our Rights and Privileges?",99 Extra-legal protests were coming.

Chief among the early colonial efforts to change the system by operating outside its boundaries was non-importation. Having failed to halt the "embarrassment" of the fishing trade, the Boston-based Society for the Encouragement of Trade and Commerce voted on a nonimportation agreement in 1768. Without legal sanction, this commercial consortium agreed to boycott British manufactured goods for one year, excepting only those items, chiefly salt, deemed necessary for the prosecution of the fishing industry. The Society succeeded in getting other commercial ports to join in the boycott. The agreement was extended for another year, and in 1769 they formed a committee of inspection to enforce the trade embargo in Boston. ${ }^{100}$ Colonists were beginning to assume the authority of regulating their own trade.

${ }^{98}$ JHRM, Vol. 41, 77.

${ }^{99}$ JHRM, Vol. 41, 72.

${ }^{100}$ See, the non-importation agreement, signed by Gloucester fish merchants Epes Sargent, Nathaniel Allen, Daniel Sargent, Winthrop Sargent, William Ellery, Jr., dated Gloucester, May 2, 1768; the list of Boston merchants in violation of the non-importation agreement, dated Boston, April 27, 1769; and the memorandum of Joseph Pierce, dated Boston, June 10, 1769, Ezekiel Price Papers, 1754-1785, MHS. 
Colonists also engaged in a number of illegal mob activities aimed specifically at His Majesty's customs collection during the 1760s. Those customs agents who seriously attempted to enforce revenue acts such as the Sugar Act were especially targeted in colonial fishing ports. Thomas Row, the tidewaiter for Salem and Marblehead responsible for checking vessels' manifests as they entered and cleared off, was brutalized for informing his superiors that the schooner Neptune was bringing foreign molasses into Salem in 1768. Row was "surrounded by a large Mob with a flag flying." Once captured, he wrote that one of the mob "waxed the hair of my head with Balls of Shoemaker's Wax, and some amongst them (I cannot say which) cut part of it off from behind." Row was then taken "to the Commons, striped of my Coat, Waistcoat, handkerchief \& hat.” According to an eyewitness, "They had tarred his Clothes all over, and then covered him with feathers, \& pinioned him into the Cart, and were carrying him through the Town as a Spectacle of Infamy; Stopping at all the Public Offices.” Row testified that the crowd "fixed two boughs with spun yarn on each side of my head." They also "put a cross made with sticks into my hand, struck me several violent blows on my head, and swore they would murder me if I did not carry it upright." When the crowd finished with Row, they took him "to the extreme part of the town," let him go, and told "him he must not show his face again in this port." ${ }^{101}$ Similar tarring and feathering went on in other colonial ports. ${ }^{102}$

Colonial mobs also specifically targeted customs vessels in an effort the thwart and change the direction of imperial policy. The customs officers for Salem and Marblehead regretfully informed the Naval Board established in Boston to facilitate customs collection "of the loss of the Custom house Boat, which was maliciously and in the most secret and private

\footnotetext{
101 "Copy of Thomas Row's Affidavit concerning the insult he received from the Mob at Salem," dated Castle William, Boston Harbor, September 9, 1768; and "Copy of a Letter from the Collector \& Comptroller of Salem and Marblehead to the Commissioners of the Customs at Boston,” NA T 1/465/259-260, 265-266.

${ }^{102}$ Hoerder, Crowd Action in Revolutionary Massachusetts, 1765-1780, 185-190.
} 
manner set on fire about twelve o'Clock last night, and was entirely consumed by four this morning." The "Perpetrators of this act" took "the Boat from the Wharf to a considerable distance in the harbor." There, they "moored her with the Chain so that no assistance from the shore could possibly be given to save her.”103 In other colonial ports, mobs carried customs vessels to the commons, or in front of town meeting halls, before setting them on fire.

These extra-legal actions did not immediately precipitate armed revolt against the British Empire. After the Sugar Act, Parliament taxed other goods without colonists' consent and the Royal Navy continued to confiscate their property. Yet, the American Revolution did not begin in the 1760s. Additional events in the North Atlantic helped widen the gulf between the colonies and the metropole.

\subsection{NEW ENGLAND'S ECONOMIC EXPANSION IN THE NORTH ATLANTIC}

In the first two chapters, we saw that during the eighteenth century New England's economic activities expanded in the North Atlantic. The transition from shallops to schooners enabled commercial fishermen to develop deep-sea fishing operations along the Northwest Atlantic littoral. Expanded crews in these larger vessels were able to catch great numbers of cod from this region. In particular, more New Englanders and more of their schooners were working the Grand Bank off Newfoundland, the richest source of cod in the entire Atlantic. As a result, New England production levels reached 350,000 quintals of dried cod in 1765, which outpaced the

\footnotetext{
103 "Extract of a Letter from the Collector \& Comptroller of Salem \& Marblehead, dated the $20^{\text {th }}$ June 1768," NA T 1/465/257.
} 
300,000 quintals produced by the resident fishing stations at Newfoundland and the 300,000 quintals produced by the West Country migratory fishing interests. ${ }^{104}$

By the middle of the eighteenth century Yankee trade vessels were also transporting greater amounts of supplies, including lumber, fishing gear, and provisions of all sorts, to British settlers in Newfoundland. In exchange, the New Englanders received mainly dried cod, manufactured goods from Europe, and bills of exchange. ${ }^{105}$ The number of New England trade vessels operating around Newfoundland increased from 31 in 1716 to 103 in $1751 .^{106}$ In part, this expanded trade was due to increased permanent population levels at Newfoundland. Settlement at the land of cod began to expand rapidly in the middle part of the century. ${ }^{107}$ More people meant more mouths to feed, and Newfoundland's topography was not conducive to largescale commercial agriculture. As a result, there was a heightened need for imported foodstuffs on the island and shrewd Yankee traders sailed into the North Atlantic with full vessels to meet this growing demand.

Through a combination of fishing and trading New Englanders were thus very active in and around Newfoundland by the middle of the eighteenth century. Slowly but surely, Yankees were seizing market share in the provision trade. By $1763,12 \%$ of the total quintals of cod caught at Conception Bay, Newfoundland, were being exchanged with colonial trade vessels for provisions. At the same time, $32 \%$ of the quintals of cod caught at Ferryland and $6.5 \%$ of the quintals caught at Old Perlican and Trinity were exchanged thus. In all, 13,697 quintals were

${ }^{104}$ Compare Vickers, Farmers and Fishermen, 154, Table 4 to Handcock, Soe longe as there comes noe women, 76, Figure 4.1.

${ }^{105}$ Head, Eighteenth Century Newfoundland, 100-132; Lounsbury, The British Fishery at Newfoundland 16341763, 190-203; and Innis, The Codfisheries, 145, 146-147.

${ }^{106}$ Innis, The Codfisheries, 145.

${ }^{107}$ Handcock, Soe longe as there comes noe women, 73-120. 
sold to colonial merchants, mostly from New England, in exchange for lumber and provisions. ${ }^{108}$ In 1764, Commodore Hugh Palliser, the British Naval officer and acting royal governor in charge of the island, calculated "A General Scheme of the Great Fishery.” While he did not distinguish between fishing and trading vessels, nor did he provide the port of origin, he observed that there were 105 "Ships from America" of 6,337 tons burden operating around Newfoundland. Given New England's historic association with the fishing industry and trade with Newfoundland, it is very likely that a large majority of these vessels were from New England ports. Moreover, the average of 60 tons per vessel fits well within the range for schooners, the Yankee vessel of choice in the eighteenth century. The largest number of "Ships from America,” 51, operated around St. John’s. By comparison, there were 141 "British Fishing Ships," which included those belonging to settlers and "all ships arriving from England and Ireland whether for Fishing, with Supplies, or Passengers, or for Cargoes,” of 14,819 tons burden. There were also 97 "British Sack Ships," representing only "those arriving from Foreign Ports, whether with Salt or for Cargoes of Fish,” of 11,924 tons burden. ${ }^{109}$ Given the fact that in 1764 there was a total of 238 British vessels operating around Newfoundland, the principal locus of cod fishing operations in the eighteenth century Atlantic world, the "American," or New England, presence was equal to $44 \%$ of this total. Or, to put this figure another way, New England's commercial activity around the land of cod represented almost half the level of activity attained by a combination of resident fishing stations in Newfoundland and West Country migratory interests.

New Englanders also did business transporting passengers from Newfoundland to the mainland colonies. In between 1713 and 1718, it was estimated that 1,000 migratory fish

\footnotetext{
${ }^{108}$ Innis, The Codfisheries, 146.

${ }^{109}$ NA CO 194/16/109.
} 
servants booked passage on Yankee vessels bound for New England ports every year. ${ }^{110}$ In 1764, Commodore Palliser observed "a constant current of seamen, artificers and fishermen through this country into America."111 In 1771, it was reported "New England vessels last year carried out of Conception Bay [Newfoundland] upwards of 500 men, some of which were headed up in casks because they should not be discovered."112 Push factors such as harsh working conditions and low wages motivated eighteenth-century workers to leave the land of cod. ${ }^{113}$ Higher wages and more temperate climes pulled these men into New England. One Newfoundlander wrote in 1700, "there being great wages given to men in New England makes men desirous to go there, and frequently attempts it." ${ }^{114}$ Of course, not every worker who left Newfoundland ended-up financially better-off. In 1763, Thomas Clark, an Irish fishing servant, fled Newfoundland only to end up "representing his distressed Circumstances, and praying Relief" from the Massachusetts General Court in Boston. ${ }^{115}$ The fact that New England was not the best poor man's country did not discourage Yankees from taking passengers' money. The immediate profits from these passages reinforced earnings from trade missions and fishing expeditions. This transportation, however, yielded severe political costs over the long run.

New England's North Atlantic commercial expansion generated conflict with powerful fish merchants in England's West Country. These merchants were primarily opposed to New England trade with Newfoundland. They opposed this trade for two reasons: it provided an encouragement to permanent settlement on the island, and it posed a threat to their flow of

\footnotetext{
${ }^{110}$ Handcock, Soe longe as there comes noe women, 29-30; and Innis, The Codfisheries, 147. Also see Pope, Fish Into Wine, 243-248.

${ }^{111}$ Cited in Innis, The Codfisheries, 147.

${ }^{112}$ Cited in Innis, The Codfisheries, 104. The date is provided by Handcock, Soe longe as there comes noe women, 29, footnote \#23.

${ }^{113}$ Handcock, Soe longe as there comes noe women, 85.

${ }_{114}$ Cited in Vickers, Farmers and Fishermen, 109. Also, see Pope, Fish Into Wine, 159-160, 183.

115 JHRM, Vol. 39, 146.
} 
supplies from England. Throughout the seventeenth and eighteenth century, merchants from the West Country fought against permanent settlement at Newfoundland as it challenged their hegemony in the region, and they viewed anyone who supported such colonization as a threat. ${ }^{116}$ In the first half of the seventeenth century, these merchants organized the Western Adventurers, a commercial consortium, to lobby Parliament against authorizing plans for permanent plantations at Newfoundland. ${ }^{117}$ In 1668 , they proposed forcibly removing settlers from the area. ${ }^{118}$ They had helped to finance settlement in New England, and the later generations of settlers were building a rival industry. West Country merchants were thus wary of plans to establish additional resident fishing stations in North America, particularly on Newfoundland, the land of cod. Yet, despite their best efforts, Newfoundland's permanent population slowly but surely continued to increase.

As a result, savvy West Country merchants tacked a different course, and by the turn of the eighteenth century they focused their energies on stopping supplies going from New England to Newfoundland. In 1696, West Country merchants complained that New Englanders were enabling settlers to stay at Newfoundland by providing them with supplies. ${ }^{119}$ In 1715 , West Country merchants again petitioned Parliament for redress of their grievances, chiefly that

\footnotetext{
${ }^{116}$ There is a debate over the extent of conflict between English fish merchants and Newfoundland settlers. Gillian Cell, Ralph Lounsbury, Harold Innis, and Bernard Bailyn have all maintained that there existed very high levels of conflict between these two parties. See, Gillian T. Cell, English Enterprise in Newfoundland, 1577-1660 (Toronto: University of Toronto Press, 1969); Lounsbury, The British Fishery at Newfoundland 1634-1763; Bailyn, The New England Merchants in the Seventeenth Century; and Innis, The Codfisheries. For their part, Peter Pope and Keith Matthews have argued that there was more symbiosis than conflict between the merchants and settlers. See, Pope, Fish Into Wine; and Keith Matthews, “A History of the West of England - Newfoundland Fisheries,” (Ph.D. Dissertation, Oxford University, 1968). W. Gordon Handcock and Grant Head can be pressed into this later crew, as they downplay the role that conflict between the two groups played in retarding permanent settlement at Newfoundland. See, W. Gordon Handcock, Soe longe as there comes noe women: Origins of English Settlement in Newfoundland (St. Johns, Newfoundland: Breakwater Books, 1989); and Head, Eighteenth Century Newfoundland. Despite this spirited and long-standing debate, none of these scholars disputes the fact that there was competition between the two groups.

${ }^{117}$ Hornsby, British Atlantic, American Frontier, 33.

${ }^{118}$ Lounsbury, The British Fishery at Newfoundland 1634-1763, 190.

${ }^{119}$ Lounsbury, The British Fishery at Newfoundland 1634-1763, 193.
} 
Newfoundland "inhabitants are supplied with provisions, tobacco, rum, sugar, rice, etc., from New England and the colonies of America." ${ }^{120}$ At this time, tobacco, sugar, and rice were enumerated articles, restricted by Navigations Acts and prohibited from direct trade with foreigners. But because there was no customs office in Newfoundland, New England trade vessels could vend these goods in open marts around the land of cod to sack ships from Europe. $^{121}$ The West Country merchants, in short, tried to show that New England's trade violated Navigation Acts and must therefore be stopped. In another petition that same year, the West Country fish merchants referred to New England as "a nest of little peddlers," and they asked that direct trade between New England and Newfoundland be prohibited. ${ }^{122}$

The English fish merchants had other grievances against New Englanders. West Country merchants wanted to monopolize the sale of supplies and provisions to fishermen operating around Newfoundland. They believed that year-round settlers living in the land of cod would procure these goods at a better price from nearby New England, so they did all they could to prevent this. ${ }^{123}$ As early as their 1668 proposal for forcibly removing settlers, West Country fish merchants argued that such removal would provide encouragement for their exports of food and supplies to the region. ${ }^{124}$ Over the next century, New Englanders continued to supply the Newfoundland region. ${ }^{125}$ It was not until 1764, when customs collection and naval enforcement were reformed, that this trade was seriously disrupted. ${ }^{126}$ In addition, the fact that New Englanders transported workers as passengers away from Newfoundland further angered

${ }^{120}$ NA CO 194/5. Cited in Innis, The Codfisheries, 144.

${ }^{121}$ Head, Eighteenth Century Newfoundland, 111-112.

122 NA CO 194/7. Cited in Innis, The Codfisheries, 145.

${ }^{123}$ Hornsby, British Atlantic, American Frontier, 33, 37.

${ }^{124}$ Lounsbury, The British Fishery at Newfoundland 1634-1763, 190.

${ }^{125}$ Head, Eighteenth Century Newfoundland, 111-126.

${ }^{126}$ The disruption of this trade will be discussed further in subsequent sections. 
merchants in England's West Country. ${ }^{127}$ At the end of the seventeenth century, the West Country fish merchants complained: "the worst thing is that the New England men carry away many of the fishermen and seamen, who marry in New England and make it their home.”128 By this means, the migratory fishing industry suffered a loss of manpower.

The British state favored West Country merchants in the eighteenth century for several reasons. West Country commercial fishing interests played a significant role in early modern England's economic development. Merchants from this region provided much of the capital behind England's westward expansion into the Atlantic. ${ }^{129}$ England's chief wool producers also resided in the West Country. ${ }^{130}$ Moreover, the eighteenth century marked the heyday of the English migratory cod fisheries around Newfoundland. During this period, cod caught off Newfoundland and sold in Southern European markets represented one of British North America's strongest export revenue streams. ${ }^{131}$

West Country merchants had influential political connections. Like West Indian planters, they tended to be absentee landlords. The wealth generated through the Newfoundland cod fisheries, like sugar capital, enabled a genteel lifestyle in England. ${ }^{132}$ Just as their tropical counterparts had done, the West Country merchants used their wealth and land-ownership in England to control seats in Parliament. ${ }^{133}$ Benjamin Lester, for example, was one of the

\footnotetext{
${ }^{127}$ Hornsby, British Atlantic, American Frontier, 33; Handcock, Soe longe as there comes noe women, 29-30; Lounsbury, The British Fishery at Newfoundland 1634-1763, 194, 223-224; and Bailyn, The New England Merchants in the Seventeenth Century, 130.

${ }^{128}$ Cited in Innis, The Codfisheries, 103.

${ }^{129}$ See chapter three.

${ }^{130}$ Hornsby, British Atlantic, American Frontier, 10.

${ }^{131}$ Newfoundland fish ranked third in terms of the value of British North American and Caribbean exports, 1764-1775, behind only sugar products and tobacco. Hornsby, British Atlantic, American Frontier, 26-28, esp. Figure 2.1.

${ }^{132}$ Hornsby, British Atlantic, American Frontier, 38, 40-41, Figure 2.8.

${ }^{133}$ For more on the involvement of West Country fish merchants in Parliament during the seventeenth century, see Lounsbury, The British Fishery at Newfoundland 1634-1763, 210, 213. For the eighteenth century, see Hornsby, British Atlantic, American Frontier, 30.
} 
wealthiest fish merchants in Poole, England. He controlled a resident fishing station in Trinity, Newfoundland, with its own wharf space, warehouse, shop, flake yard, shipyard, sail loft, forge, cookroom, and vessels. Lester also owned real estate in Poole, served as the town mayor, and as a member of the House of Commons. In his mansion house in Poole, Lester had two dried cod fillets carved in marble on his fireplace mantelpiece to symbolize the source of his wealth and political power. ${ }^{134}$ They also hired professional lobbyists to protect their interests throughout the colonial era. $^{135}$

Parliament also responded to the claim of West Country merchant that the migratory fishing industry was a "nursery" for naval seamen. ${ }^{136}$ Men such as Adam Smith equated "the extension of the fisheries of our colonies" with an "increase [in] the shipping and naval power of Great Britain.”137 The assumption among English elites was that commercial fishing trained men to handle wooden sailing vessels, gave them knowledge of trade winds and ocean currents, and familiarized them with life at sea. Such training, it was believed, made commercial fishermen ideal labor pools from which to draw manpower for the navy in wartimes. Moreover, the fishing industry stimulated growth in shipbuilding and other maritime trades that could support naval power during periods of conflict. The expansion of the Royal Navy around the turn of the eighteenth century, the near-constant wars with France, and the huge demands for

\footnotetext{
${ }^{134}$ Hornsby, British Atlantic, American Frontier, 30, 34, 38-39, 40-41, Figures 2.5, 2.7, 2.8; and Jerry Bannister, The Rule of the Admirals: Law, Custom, and Naval Government in Newfoundland, 1699-1832 (Toronto: University of Toronto Press; for the Osgoode Society for Canadian Legal History, 2003), 156-158. Members of the "codfish aristocracy" in eighteenth century Salem, Massachusetts placed carved and gilded images of cod throughout their mansions. Indeed, following the American Revolution one of these carved images was prominently displayed in the hall of the Massachusetts House of Representatives. Hunter, Purchasing Identity in the Atlantic World, 145, 146.

${ }^{135}$ Pope, Fish Into Wine, 188; and Hornsby, British Atlantic, American Frontier, 33.

${ }^{136}$ Handcock, Soe longe as there comes noe women, 25; Lounsbury, The British Fishery at Newfoundland 16341763, 329-330; and Innis, The Codfisheries, 131, esp. footnote \#126.

${ }^{137}$ Smith, An Inquiry into the Nature and Causes of the Wealth of Nations, 544. For an early seventeenth century argument that the way to increase maritime commerce and naval strength was to follow the Dutch model and encourage a commercial fishing industry, see Tobias Gentleman, England's Way to Win Wealth, and to Employ Ships and Mariners (London, 1614).
} 
maritime labor that resulted, only served to deepened the importance of training English sailors. $^{138}$ The 1699 Newfoundland Act required North American colonial vessels traveling to Newfoundland to post a bond guaranteeing they would not bring back any passengers from the island. The purpose of this bond was expressly to preserve England's "nursery of seamen," or the West Country migratory fishing industry. In addition, the act required migratory fishing vessels to carry a certain percentage of landsmen on board in order to train them in the maritime nursery. The act remained in effect until $1867 .^{139}$

The influence of West Country fish merchants and the importance of the migratory fishing industry bore fruit in 1764, as the British Navy under Commodore Hugh Palliser began forcibly removing New England fishing and trading vessels from Newfoundland waters. After the Newfoundland Act, British naval officers governed the land of cod through the summer fishing season. ${ }^{140}$ Palliser ruled the region with an iron fist between 1764 and 1769 . Instructed to enforce the Sugar Act and prevent clandestine trade between New England colonists and the French North Atlantic islands, Palliser actively supported West Country fishing interests and upheld the 1699 Act. ${ }^{141}$ He issued orders during his first year as governor expressly forbidding anyone to transport passengers from Newfoundland to the North American colonies without first entering on board his personal flagship and asking for his written permission. Violators risked

\footnotetext{
${ }^{138}$ For more on the turn-of-the-century naval expansion and the demands for maritime labor, see Linebaugh and Rediker, The Many-Headed Hydra, 143-173; and Lounsbury, The British Fishery at Newfoundland 1634-1763, 223.

${ }^{139}$ For more on the Newfoundland Act, see Handcock, Soe longe as there comes noe women, 27, 29, 85; Lounsbury, The British Fishery at Newfoundland 1634-1763, 213-244; and Innis, The Codfisheries, 108. To date, no work has systematically examined the historic relationship between commercial fishing and early modern naval warfare.

${ }^{140}$ Bannister, The Rule of the Admirals, 27, 148-149, 158-162.

${ }^{141}$ See Palliser's commission as governor, which was read in the fort at St. John's on June 19, 1764, Colonial Secretary Letterbooks, 1752-1765, MUMHA, 218. In a personal letter from Lord Egremont to Palliser, dated Whitehall, July 9, 1763, the British naval officer was formally warned "that the King will not Pass over unnoticed any Negligence or Relaxations on the Part of any Persons employed in his Service in a matter on which His Majesty lays so much Stress and in which the fair Trade of all His faithful subjects is so Essentially interested.” Ibid., 225.
} 
having their vessels impounded paying a stiff penalty. ${ }^{142}$ In 1765 , George III strengthened the instructions, ordering Palliser to prevent "the great Prejudice \& discouragement of the Ship Fishery,” or the West Country migratory fishing industry. ${ }^{143}$ Eager to please, Palliser interpreted these royal instructions to include New England fishing vessels in addition to trade ships. He ordered the warships under his command patrolling Newfoundland waters to confiscate any fish found on New England vessels operating in the region. Palliser further authorized the seizure of these vessels, and the use of corporal punishment on repeat Yankee offenders. ${ }^{144}$ New England fish merchants complained through their agent in London. ${ }^{145}$ Palliser, however, successfully explained his actions to the Board of Trade. He justified these measures by stating that he wanted Newfoundland and the surrounding area to be a British, "not American,” fishery. He added that allowing the "Americans," by which he meant colonists in general, but New Englanders in particular, to fish in Newfoundland waters, was "ruinous" to the "British" fishing industry. ${ }^{146}$ In short, Palliser, like the West Country fishing interests, saw the colonists not as fellow British subjects entitled to equal rights, but as mere interlopers. ${ }^{147}$ And Palliser's actions did have a cumulative negative effect on colonial New England commerce. The number of "Ships from America” operating around Newfoundland declined from 105 in 1764 to 83 in

\footnotetext{
${ }^{142}$ See, Palliser's Orders "for Vessels Trading to America not to carry Passengers $\&$ to sail by the $5^{\text {th }}$ of next Month,” St. Johns, October 4, 1764; Palliser's "Order to American Vessels not to convey Passengers,” St. Johns, November 1, 1764; and Palliser's "Decree upon Thomas Stout, Master of the Brig Good Intent," St. Johns, September 16, 1765, Colonial Secretary Letterbooks, 1752-1765, MUMHA, 251-252, 278, 340.

${ }^{143}$ George III's instructions to his royal governor, Hugh Palliser, St. James, May 10, 1765, Colonial Secretary Letterbooks, 1752-1765, MUMHA, 285.

${ }^{144}$ See, the Ezekiel Price Papers, 1754-1785, MHS; and Letter from Gov. Palliser to Gov. Barnard at Boston, “Great St. Lawrence Harbor,” July 15, 1765, Colonial Secretary Letterbooks, 1752-1765, MUMHA, 290. Also, see Jonathan Millet, deposition, September 13, 1766; and Samuel Masury, deposition, September 13, 1766, Misc. Bound Manuscripts, 1766-1769, MHS.

${ }^{145}$ See, Letter from Dennys DeBerdt, MA colonial agent, in London to the Boston committee for the encouragement of trade and commerce, dated London, March 14, 1767, Ezekiel Price Papers, 1754-1785, MHS.

${ }^{146}$ Letter from Palliser to the Board of Trade \& Plantations in London, dated St. John's, Newfoundland, October 30, 1765, NA CO 194/16/170-174.

${ }^{147}$ Indeed, Palliser went so far as to publicly accuse New England fishermen of "piracy.” JHRM, Vol. 43, Part II, 257.
} 
1766. ${ }^{148}$ Because he was effective in defending the West Country interests around Newfoundland he retained Parliamentary support - he was, after all, following instructions.

By themselves, the incidents in the North Atlantic that increased operating costs associated with the colonial fishing industry and trade did not immediately lead to demands for independence. Instead, the cumulative effect of efforts to restrict and regulate New England's commercial expansion along the Northwest Atlantic littoral and in the West Indies contributed to rising sentiment among colonists that the British state violated their economic interests. Moreover, the state's decisions placed additional burdens on colonial merchants and workers struggling to eke out an existence in a fiercely competitive industry. The load on colonists' backs was increasingly insupportable.

\subsection{THE FISHERIES BILL}

New Englanders did not have the best reputation in London during the late 1760s and early 1770s. To members of Parliament who understood the economic importance of the British West Indian sugar islands and the West Country migratory fishing industry, it seemed as though aggressive New Englanders were damaging imperial interests. Moreover, the riots and nonimportation agreements in New England made it appear that the region was lawless, and in a state of rebellion. As early as 1766, Lord Grenville, the head of the Treasury Department,

declared the behavior of the colonists "highly criminal." 149 In February 1775, prior to the shot heard around the world, Lord North, the prime minister, stated that the New Englanders were "in

\footnotetext{
${ }^{148}$ NA CO 194/16/109, 194/16/317.

${ }^{149}$ PDBP, Vol. 2, 149.
} 
a state of actual rebellion." ${ }^{150}$ In order to bring the colonists to heel, then, and in order to strike against the source of colonial smuggling and the threat to the migratory fishing industry, some members of Parliament proposed a moratorium on the New England fishing industry in 1775.

Lord North fought hard in Parliament to get a bill passed that would simultaneously "restrain the Trade and Commerce" of the North American colonies "to Great Britain, Ireland, and the British Islands in the West Indies," and "prohibit such Provinces and Colonies from carrying on any Fishery on the Banks of Newfoundland, or other Places therein to be mentioned, under certain Conditions, and for a Time to be limited.” The time limitation North had in mind was initially "till the New Englanders should return to a sense of their duty to the mother country, and submit to her supreme authority.” Eventually, he agreed to limit the moratorium to one year, and he allowed colonists to apply for fishing licenses, having first given evidence of "their good behavior" to royal governors, "or upon their taking a test of acknowledgment of the rights of Parliament." He justified the moratorium by stating "the Fishery on the Banks of Newfoundland, and the other Banks, and all the others in America, was the undoubted right of Great Britain. Therefore we might dispose of them as we pleased.” He acknowledged that Massachusetts was the foremost fishing colony, producing the largest quantity of fish for use in trade for foreign contraband, and that rebellion was chiefly to be found in this region. Yet New Hampshire, Rhode Island, and Connecticut were included in the moratorium because of their "vicinity" to Massachusetts (which he believed made them more susceptible to treason) and because the other colonies afforded Massachusetts' inhabitants "an opportunity of carrying on the fishery." In a supplementary bill, North further proposed "that an augmentation of 2,000 seamen should be made," and "a proper number of frigates" be stationed "in the most beneficial

${ }^{150}$ PDBP, Vol. 5, 352. 
manner for commanding the whole coast of North America.” He justified this naval augmentation by stating that without proper military force, "the people of New England could not be restrained from the fishery.”"151

On March 21, 1775, Lord North’s Restraining Act was passed in the House of Lords by an overwhelming vote of 73 to $21 .^{152}$ The Act was published in newspapers throughout the colonies. The clause pertaining to the fisheries formally stated:

And it is hereby further enacted by the authority aforesaid, that if any ship or vessel being the property of the subjects of Great Britain, not belonging to and fitted out from Great Britain or Ireland, or the islands of Guernsey or Jersey, shall be and, after the twentieth day of July, one thousand, seven hundred and seventyfive, carrying on any fishery, of what nature or kind so ever, upon the banks of Newfoundland, the coast of Labrador, or within the river or gulfs of Saint Lawrence, or upon the coast of Cape Breton, or Nova Scotia, or any other part of the coast of North America, or having on board materials for carrying on any such fishery, every such ship or vessel, with her guns, ammunition, tackle, apparel, and furniture, together with the fish, if any shall be found on board, shall be forfeited, unless the master or other person having the charge of such ship or vessel, do produce to the commander of any of His Majesty's ships of war, stationed for the protection and superintendence of the British fishery in America a certificate, under the hand and seal of the Governor or commander in chief of any of the colonies or plantations of Quebec, Newfoundland, Saint John, Nova Scotia, New York, New Jersey, Pennsylvania, Maryland, Virginia, North Carolina, South Carolina, Georgia, East Florida, or West Florida, setting forth, that such ship or vessel, exercising her name, and the name of her master, and describing her built and burthen, both fitted and cleared out from some one of the said colonies or plantations, in order to proceed upon the said fishery, and that the actuality and bona fide belongs to, and is the whole and entire property of His Majesty's subjects, inhabitants of the said colony or plantation; which certificates such Governors or commanders in chief respectively are hereby authorized to grant. ${ }^{153}$

${ }^{151}$ PDBP, Vol. 5, 410, 411, 412-413, 418. By June 30, 1775, there were 29 British warships stationed off the coast of North America between Florida and Nova Scotia. These warships carried a total of 584 guns and 3,915 men. NDAR, Vol. 1, 785. For evidence that these warships enforced North's restraining act, see ibid., 1081-1082.

${ }^{152}$ PDBP, Vol. 5, 584. The twenty-one dissenters included four dukes, a marquess, seven earls, three viscounts, and six barons. Ibid., 589. The Act was previously approved by the Commons on February 28, 1775, by a vote of 97 to 24 . Ibid., 480.

153 The Newport Mercury, 5-8-1775; and Virginia Gazette, 18 May 1775. 
The entire British Navy operating in the Atlantic was "required and enjoined to examine, search, and visit, all ships and vessels carrying on the said fisheries," and to "seize, arrest, and prosecute" those vessels "which shall not have on board the certificate herein before required." The Fisheries Bill mandated that any persons providing customs agents or naval personnel with a "false certificate, cocket, or clearance, for any of the purposes required or directed by this act, such persons shall forfeit the sum of five hundred pounds, and be rendered incapable of serving his Majesty, his heirs, and successors, in any office whatsoever.” The loss of $£ 500$ was also mandated for every offence of "counterfeiting, erasing, altering, or falsifying, any certificate, cocket, or clearance." ${ }^{154}$ By November, all of the thirteen North American colonies were considered in open rebellion, and the Restraining Act was extended to include even North American colonists outside of New England. ${ }^{155}$

In April 1775, Lord North convened a special fisheries committee that specifically aimed to use state power to supplant the New England cod fishing industry. In particular, the committee resolved to use state funds to sponsor certain bounties. The first twenty-five fishing vessels above 50 tons burden to return from Newfoundland with at least 10,000 cod caught on the banks, and then make a second fishing expedition, would earn $£ 40$. The next 100 vessels to make these two trips would earn $£ 20$ each, while the following 100 vessels to do likewise were to earn $£ 10$ each. North maintained that "the design" of these bounties "was to encourage the going out early enough to make two voyages a year.” He explained that "it would be infinitely

\footnotetext{
${ }^{154}$ The Newport Mercury, 5-8-1775. As a result of the effective lobby of fellow Quakers in London, Nantucket whalemen were eventually given a special exemption from the general moratorium on fishing. For the exemption, see ibid. For evidence of this lobbying, see PDBP, Vol. 5, 479-480. Jacob M. Price notes that the economic interests of North American Quakers were exceptionally well represented in Parliament during the eighteenth century. He attributes this exceptional representation to the fact that Quakers lived and worked throughout England, in addition to North America. Transatlantic Quaker merchants communicated regularly, and they held a yearly gathering in London. Price, "Who Cared about the Colonies?" 423. Also, see Olson, Making the Empire Work.

${ }^{155}$ PDBP, Vol. 6, 277-278, 290-291.
} 
for the advantage of this country [i.e. England], to make Newfoundland as much as possible an English island, rather than an American colony.” He further noted that these bounties would encourage "the bank ship fishery," or the West Country migratory fishing industry, which he personally considered "the great nursery of seamen." Thus, the British state was willing to spend $£ 4,000$, “a sum not great enough to alarm anyone," in North’s words, in order to encourage West Country fishing interests to catch more fish while the New England commercial fishing industry was closed. ${ }^{156}$ North pushed this program at the suggestion of the West Country merchants, who had made such a proposal during the Parliamentary debates over the Restraining Act in February. ${ }^{157}$

Opposition to the Restraining Act was immediate and fierce, both in England and in the colonies. On the same day the Act passed the House of Lords, sixteen of the twenty-one dissenting peers signed a public declaration, using a mixture of Lockean and classical republican language to elucidate seven reasons for their opposition. First, they believed "that government which attempts to preserve its authority by destroying the trade of its subjects, and by involving the innocent and guilty in a common ruin...admits itself wholly incompetent to the end of its institution." Second, the dissenters maintained that without the ability to fish, colonial debtors could not reimburse their creditors in England. "Without their fishery," which drew in the most export revenue into New England, they explained, "that is impossible.” "Eight hundred thousand pounds of English property," the peers warned, "belonging to London alone, is not to be trifled

\footnotetext{
${ }^{156}$ PDBP, Vol. 6, 24. A Boston newspaper reported on July 3, 1775 news "from Newfoundland...that a greater Number of Vessels had arrived from Europe for the Fishery than usual, as the Colonies were not permitted to Fish on the Banks there.” Boston Gazette, July 3, 1775.

${ }^{157}$ PDBP, Vol. 5, 480. Merchants from Poole, the foremost port in England involved in the migratory fishing industry at Newfoundland, maintained "the said Bill, if carried into a Law, will not by any Means be injurious to Commerce... because the Foreign Markets [i.e. ports in Iberia, Italy, and the Wine Islands] can be amply supplied by extending the Newfoundland Fishery of Subjects resident in England....and that the Newfoundland Fishery of the Mother Country is a constant Nursery of Seamen for the Navy, that great Bulwark of the Nation, every Fifth Man employed being, by the $10^{\text {th }}$ of William the Third [the 1699 Newfoundland Act], obliged to be a Landsman."
} 
with.” Third, the dissenters objected to the violation of colonial New England charters, which made them "especially entitled to the fishery," and "which have never been declared forfeited." Fourth, they considered the offer to allow Yankees to fish again once all boycotts ceased nothing less than an effort "to bribe the nation into an acquiescence" by holding out "the spoils of the New England fishery, worth upwards of Three hundred thousand Pounds a year.” The dissenters considered this "scheme" and "arbitrary act" an "indecency." Fifth, they maintained that Lord North's belief in "the cowardice of his Majesty's American subjects," or the idea that colonists would not oppose the Act, did not "have any weight itself." Moreover, they stated "nothing can tend more effectually to defeat the purposes of all our coercive measures than to let the people, against whom they are intended, know, that we think our authority founded in their baseness; that their resistance will give them some credit, even in our own eyes....This is to call for resistance, and to provoke rebellion." Sixth, the dissenting peers objected to the fact that "the interdict from fishing and commerce” could only be terminated once royal governors and customs officials confirmed the non-importation agreements had stopped. The peers believed giving governmental "subordinates" the power to "deliver over several hundred thousands of our fellow-creatures to be starved...without any rule to guide their discretion, with [out] any penalty to deter from an abuse of it," was "a strain of such tyranny, oppression, and absurdity, as we believe never was deliberately entertained by any grave assembly.” The peers believed North's terms mandated that the colonies "submit to be the slaves, instead of the subjects, of Great Britain.” Last, those signing the public declaration objected to the fact that the Fisheries Bill was presented as "a measure of retaliation" for colonial disobedience, "upon a supposition that the colonies have been the first aggressors.” For the dissenters, the colonial non-importation associations were "no more than a natural consequence of antecedent and repeated injuries." 
They viewed the Act, therefore, not as "a measure of retaliation," but as "a most cruel enforcement of former oppressions.” In their prophetic opinion, the "consequence” of the Act would not be colonial submission, but "a civil war, which may probably end in the total separation of the colonies from the mother country."158 The peers' protest was published in colonial newspapers. ${ }^{159}$

Individual peers also gave speeches in Parliament, protesting the Restraining Act. Charles Prat, Earl of Camden, a Whig member of the House of Lords and the judge who acquitted John Wilkes, compared the Act to other Parliamentary legislation and found it to be the most objectionable. It was his belief "that this was at once declaring war, and beginning hostilities in Great Britain.” After emphasizing the word “war” several times, Camden stated he "knew no other name to give it, for that it carried famine, the worst engine of war, into the bowels of the [American colonies], and consequently demanded resistance from the tamest and most servile of mankind.”160 Charles Watson-Wentworth, better known as Lord Rockingham, a Whig leader during the imperial crisis, believed the Act to be one of the foremost causes of the American Revolution. In a speech in the House of Lords on November 5, 1776, he explained to MPs such as Lord North, who were shocked at the level of colonial resistance to that point, that Yankee "seamen and fishermen being indiscriminately prohibited from the peaceable exercise of their occupations, and declared open enemies, must be expected, with a certain assurance, to betake themselves to plunder, and to wreak their revenge on the commerce of Great-Britain.”161

${ }^{158}$ PDBP, Vol. 5, 584-585.

${ }^{159}$ The Providence Gazette, May 20, 1775; The Pennsylvania Evening Post, May 11, 1775; and Protest of the Lords... (New York: no publisher given, 1775), Early American Imprints, Series I: Evans \#14091.

${ }^{160}$ Lord Camden's Speech on the New-England Fishing Bill (Newport, R.I.: S. Southwick, 1775), Early American Imprints, Series I: Evans \#42788.

${ }^{161}$ The Norwich Packet and the Connecticut, Massachusetts, New-Hampshire, and Rhode-Island Weekly Advertiser, April 7-14, 1776. 
Rockingham was right. Colonial fishermen responded to the Restraining Act with direct action. They helped lay siege to British forces at Boston; converted their fishing vessels into warships, manned privateers; enlisted in state navies and in the U.S. Navy. They ultimately were able to "wreak their revenge on the commerce of Great-Britain."162 Colonists interpreted the Restraining Act as a state sanction of the Navy's earlier actions, and the clause pertaining to the fishing industry was known unofficially and un-affectionately in the colonies as "Palliser's Act.” ${ }^{\prime 63}$ The Act affected - and outraged - workers and merchants alike. Workers already hungry for employment because of underemployment and the increasingly exploitative nature of work in the industry lost the engine of maritime employment in New England. Increasingly wealthy merchants had much to lose in having their schooners sit idle in the harbors and their overseas orders sit unfilled, waiting for competitors to step in and fill the void the way New Englanders did during the English Civil War.

Ultimately, a combination of the Sugar Act and the Fisheries Bill convinced those involved with the New England cod fishing industry that the British state no longer supported their interests. The formal break between periphery and core took place in 1776. Parliament did not begin with the goal of destroying the colonial fishing industry. The moratorium imposed on the New England fisheries was certainly not inevitable. But it did have economic roots in a series of state decisions to back West Indian and West Country interests. Did the British state realize the nature of New England's economic expansion in the Atlantic in the eighteenth century and its concomitant political ramifications? In the final analysis, taxation and interventionist state commercial regulation of the colonial commercial fishing industry fed the fires of colonial animosity toward the British State and help explain why more New Englanders participated in

\footnotetext{
162 These military actions will be explored in detail in the following chapter.

${ }^{163}$ Bannister, The Rule of the Admirals, 162.
} 
the Revolutionary War than any other regional group. The following chapter will explore the ways in which New England's most lucrative peace time industry was converted into an effective military machine. 


\subsection{THE SINEWS OF WAR: PROFIT AND THE MILITARY MOBILIZATION OF A PEACE TIME INDUSTRY}

"The New England fishery in particular was, before the late disturbances, one of the most important, perhaps, in the world." - Adam Smith, An Inquiry Into the Nature and Causes of The Wealth of Nations, $1776 .{ }^{1}$

"The stagnation of the Fishery furnished us with means for cruising against the enemy's property.” - Resolve of a Boston town meeting at Faneuil Hall, December $11,1781 .^{2}$

As Adam Smith observed, “disturbances" such as an interventionist British state and the coming of the American Revolutionary War spoiled the lucrative commercial fishing industry in New England. Fishermen were no longer allowed to ply their trade. Fish merchants could not invest their capital in customary ways. Fleets of fishing vessels remained moored in their colonial harbors. One can see in the large gaps in fish merchant's ledger books between 1775 and 1783 that the war caused a decline in dried cod production. ${ }^{3}$ In April 1776, merchants in Cape Ann, Massachusetts petitioned for financial recompense and estimated that their fleet of " 80 fishing

\footnotetext{
${ }^{1}$ Adam Smith, An Inquiry Into the Nature and Causes of The Wealth of Nations, Max Lerner, ed., (New York: The Modern Library, 1937; orig, pub. in 1776), 544-545.

${ }^{2}$ Gentlemen, the inhabitants of the town of Boston... (Boston: Benjamin Edes and Sons, 1781), Early American Imprints, Series I: Evans \#17105.

${ }^{3}$ For evidence that merchants stopped hiring fishermen to produce dried cod during the Revolution, see Thomas Pedrick Account Book, 1760-1790, MDHS; Richard Pedrick Account book, 1767-1784, MDHS; Joshua Burnham Papers, 1758-1817, JDPL; William Knight Account Book, 1767-1781, JDPL; Daniel Rogers Account Book, 1770 1790, JDPL; John Stevens Account Book, 1769-75, JDPL; Richard Derby Ledger, 1757-1776, JDPL; and Thomas Davis Account Book, 1771-78, JDPL.
} 
Schooners” had declined in value from "£300” to “£150 Each,” because they had been idled as a result of conflict. The merchants claimed a loss of $£ 12,000$ for this redundancy, in addition to $£ 6,000$ for "Materials for Curing fish; Lost Wholly;" and £8,000 "Loss on the Income [read profit] of 80 Sail fishing Vessels a[t] £100 Each.” At the same time, Salem merchants reported that their fleet of fifty "Fishing Vessels" were worth half as much as a result of the war, and they claimed a loss of $£ 7,500$ for this depreciation. Salemites further claimed losses of $£ 2,500$ for "Materials for curing \& Drying fish" that were "Totally Destroyed;" and £5,000 for "the Loss of the Fishing 1 Year.” ${ }^{4}$ Merchants in Chatham, Massachusetts, took stock after the war and calculated that they lost twenty-three of their twenty-seven fishing vessels as a direct result of the Revolution. ${ }^{5}$ The coastal commercial cod fishing industry proved no more resistant to the vicissitudes of war than the inland production of colonial grain, flour, and rice. ${ }^{6}$ Yet, this maritime industry did not simply fade into oblivion. As the Boston merchants who attended the town meeting in 1781 recognized, the disruption of the fishing industry actually contributed in significant ways to the American war effort. In short, the commercial cod fishing industry was converted from the peace-time production of dried cod into a military machine.

Over the past thirty years, scholars interested in the American Revolutionary War have reconceptualized the nature of the armed conflict. For the most part, military historians have

\footnotetext{
${ }^{4}$ See, "Estimate of the Loss on Income \& the Trade of Cape Ann from April 1775 to April 1776," and "Estimate of the Loss on Income and Trade for the Town of Salem," April 30, 1776, NDAR, Vol. 4, 1323-1325.

5 "Description of Chatham, In The County of Barnstable, September, 1802," in Massachusetts Historical Society Collections, First Series, Vol. 8, (New York: Johnson’s Reprint Corporation, 1968), 153.

${ }^{6}$ For more on the adverse impact the Revolution had on inland agricultural sectors of the colonial economy, see Brooke Hunter, "Wheat, War, and the American Economy during the Age of Revolution," William and Mary Quarterly, $3^{\text {rd }}$ Series, Vol. LXII, No. 3 (July, 2005), 505-526; and Richard Buel, Jr., In Irons: Britain's Naval Supremacy and the American Revolutionary Economy (New Haven: Yale University Press, 1998), esp. ch. 1, "The Grain Economy of the Revolution.”
} 
moved away from a narrow focus on leadership, strategy, logistics, and battlefield tactics. ${ }^{7}$ Increasingly, practitioners of "new” military history have examined the social composition of the rank and file along with the various relationships between the Continental Army and the societies that created and perpetuated it. ${ }^{8}$ It is now widely accepted that class, ideology, and gender norms informed the processes by which men and resources were mobilized for the Army. Yet, to date, scholars have not considered the conversion of peace-time industries as crucial to the war effort.

This chapter will focus on how the New England cod fishing industry was transformed through the crucible of war. To be sure, scholars who have explored the history of the U.S. Navy

\footnotetext{
${ }^{7}$ Examples of more traditional military history include, George Athan Billias, ed., George Washington's Generals and Opponents: Their Exploits and Leadership (New York: Da Capo Press, 1994); Piers Mackesy, The War for America, 1775-1783, 3rd ed., (Lincoln: University of Nebraska Press, 1992); James A. Huston, Logistics of Liberty: American Services of Supply in the Revolutionary War and After (Newark: University of Delaware Press, 1991); Don Higginbothom, The War of American Independence: Military Attitudes, Policies, and Practice, 17631789, $2^{\text {nd }}$ ed., (Boston: Northeastern University Press, 1983); John Shy, Toward Lexington: The Role of the British Army in the Coming of the American Revolution (Princeton: Princeton University Press, 1965); and George Athan Billias, General John Glover and His Marblehead Mariners (New York: Henry Holt and Company, 1960).

${ }^{8}$ Examples of “new” military history include, Buel, Jr., In Irons; Holly A. Mayer, Belonging to the Army: Camp Followers and Community during the American Revolution (Columbia, S.C.: University of South Carolina Press, 1996); Charles Patrick Neimeyer, America Goes to War: A Social History of the Continental Army (New York University Press, 1996); Harold E. Selesky, War and Society in Colonial Connecticut (New Haven: Yale University Press, 1990); Don Higginbotham, War and Society in Revolutionary America: The Wider Dimensions of Conflict (Columbia, S.C.: University of South Carolina Press, 1988); E. Wayne Carp, To Starve the Army at Pleasure: Continental Army Administration and American Political Culture, 1775-1783 (Chapel Hill: University of North Carolina Press, 1984); Fred Anderson, A People's Army: Massachusetts Soldiers \& Society in the Seven Year's War (Chapel Hill: University of North Carolina Press, 1984); Richard Buel, Jr., Dear Liberty: Connecticut's Mobilization for the Revolutionary War (Middletown, Conn.: Wesleyan University Press, 1980); Charles Royster, A Revolutionary People at War: The Continental Army and American Character, 1775-1783 (Chapel Hill: The University of North Carolina Press, 1979); Robert A. Gross, The Minutemen and Their World (New York: Hill and Wang, 1976); and John Shy, A People Numerous and Armed: Reflections on the Military Struggle for American Independence (Oxford: Oxford University Press, 1976). Also, see Walter Leslie Sargent, "Answering the Call to Arms: The Social Composition of the Revolutionary Soldiers of Massachusetts, 1775-1783.” (Ph.D. Dissertation, University of Minnesota, 2004); and William Arthur Baller, "Military mobilization during the American Revolution in Marblehead and Worcester, Massachusetts.” (Ph.D. Dissertation, Clark University, 1994). Neither Sargent nor Baller examine the occupational identities of Revolutionary soldiers. Nor do they look at how the nature of work in the commercial fishing industry shaped military experience. And they do not fully probe the wartime mobilization of labor and capital in the fishing industry.
} 
have widely recognized the formidable role fishing vessels played in the Revolution. ${ }^{9}$ But, even historians mindful of maritime matters have not explored the use of these vessels in the wider context of the military conversion of the commercial fishing industry. Similarly, scholars investigating the colonial New England fisheries have observed the war-time transformation of this industry only in passing. ${ }^{10}$ Yet the Revolutionary War itself cannot be adequately explained without examining how the New England fishing industry contributed to the war effort for two fundamental reasons. First, colonies from this region contributed more manpower to the war effort on a consistent yearly basis for the duration of the conflict than any other region. ${ }^{11}$ Moreover, in any given year no state ever provided more men for service in the Continental

\footnotetext{
${ }^{9}$ Robert Gardiner, ed., Navies and the American Revolution, 1775-1783 (London: Chatham Publishing, in association with the National Maritime Museum, 1996), 67; Chester G. Hearn, George Washington's Schooners: The First American Navy (Annapolis: Naval Institute Press, 1995); David Syrett, "Defeat at Sea: The Impact of American Naval Operations upon the British, 1775-1778," in Maritime Dimensions of the American Revolution (Washington, D.C.: Naval History Division, Department of the Navy, 1977), 13-22; William M. Fowler, Jr., Rebels Under Sail: The American Navy During the Revolution (New York: Charles Scribner’s Sons, 1976); Nathan Miller, Sea of Glory: A Naval History of the American Revolution (Charleston, South Carolina: The Nautical \& Aviation Publishing Company of America, 1974); Donald W. Beattie and J. Richard Collins, Washington's New England Fleet, (Boston: Newcomb and Gauss Co., 1964); William Bell Clark, George Washington's Navy: Being An Account of his Excellency's Fleet in New England (Baton Rouge: Louisiana State University Press, 1960); Samuel Eliot Morison, John Paul Jones, A Sailor's Biography (Boston: Little, Brown and Company, 1959), 35; Dudley W. Knox, The Naval Genius of George Washington (Boston: Houghton Mifflin, 1932); and Octavius Thorndike Howe, Beverly Privateers In The American Revolution (Cambridge, Mass.: John Wilson and Son, 1922). Several prominent naval historians, however, have not mentioned the use of fishing vessels: Raymond G. O'Connor, Origins of the American Navy: Sea Power in the Colonies and the New Nation (Lanham, MD: University Press of America, 1994); and Alfred T. Mahan, The Major Operations of the Navies in the War of American Independence (Boston: Little, Brown, and Company, 1913).

${ }^{10}$ See, Daniel Vickers, Farmers and Fishermen: Two Centuries of Work in Essex County, Massachusetts, 16301830 (Chapel Hill: The University of North Carolina Press, 1994), 264; Harold Adams Innis, The Codfisheries: The History of an International Economy (New Haven: Yale University Press, 1940), 206; and Raymond McFarland, A History of the New England Fisheries (New York: D. Appleton \& Company, publishers for the University of Pennsylvania, 1911), 121-123.

${ }^{11}$ In 1775, New England provided 91\% of the manpower for the Continental Army, while the Mid-Atlantic region provided the remainder. In 1776, New England provided 50\% of the same type of manpower; $28 \%$ for the Mid-Atlantic region; and 22\% for the Southern region. In 1777, the equivalent figures were $40 \%$; $25 \%$; and 35\%. In 1778, 39\%; 24\%; and 37\%. In 1779, 41\%; 26\%; and 33\%. In 1780, 45\%; 33\%; and 22\%. In 1781, 55\%; 26\%; and 19\%. In 1782, 52\%; 23\%; and 25\%. In 1783, 54\%; 27\%; and 19\%. Thomas L. Purvis, Revolutionary America, 1763-1800 (New York: Facts on File, 1995), 234-240, Table 8.53. These figures are based on the number of men actually furnished, not the quotas required. In addition, at the start of the war, three of the four major generals under George Washington were from New England, and seven of the eight brigadier generals were from this region. Higginbothom, The War of American Independence, 89-90. Also, four of the seven members of the first Naval Committee appointed by the Continental Congress in 1775 were New Englanders. Morison, John Paul Jones, A Sailor's Biography, 36.
} 
Army than Massachusetts, which had been the foremost fishing colony. ${ }^{12}$ Second, New England fishermen and fish merchants made a variety of important contributions to the war effort. Trade routes and networks of trust were converted into supply lines for munitions. ${ }^{13}$ Colonial fishing vessels were transformed into armed warships. Fish that had been used to provision free and slave laborers around the Atlantic world now helped to feed fighting men in the armed forces. And fishermen themselves mobilized for war in a variety of ways.

The classical Roman statesman Cicero famously recognized the age-old connection between the world of commerce and the way of war in his Orationes Philippicae: "the sinews of War are infinite money." That is to say, the military force with the best ability to fund soldiers, supplies, and technology will have more of these things, and in the end usually prevail. Revolutionary America generated an endless monetary supply through the power of the printing press. The Continental Congress began printing paper currency in June 1775, and by the end of the year it had issued \$6 million. The following year, \$15 million dollars were printed. After just three years, a total of $\$ 72$ million had been put into circulation. ${ }^{14}$ Although highly inflationary, these efforts helped enable Congress to mobilize an increasingly market-oriented society that experienced the closure of an entire industry and the economic displacement of a cross-section of merchants and laborers. This is not to say that individuals decided to resist British authority solely out of economic self-interest. ${ }^{15}$ Rather, in addition to political grievances

\footnotetext{
12 Purvis, Revolutionary America, 1763-1800, 234-240, Table 8.53.

${ }^{13}$ For more on the important role networks of trust played in circumnavigating mercantilist boundaries in eighteenth century Atlantic commerce, see David Hancock, Citizens of the World: London Merchants and the Integration of the British Atlantic Community, 1735-1785 (Cambridge: Cambridge University Press, 1995).

${ }^{14}$ Buel, Jr., In Irons, 43-45.

15 There is a debate among military historians of the American Revolution as to why men fought against British authority. Some, including Selesky, have argued "the people" fought "to protect the political rights they already possessed.” Selesky, War and Society in Colonial Connecticut, 228. Others, such as Gross, hold up as decisive material factors such as overpopulation, underemployment, and the British Army's assault on colonial property. Gross, The Minutemen and Their World. For a good historiographic overview of this debate, see Peter Karsten,
} 
surrounding representative government and cultural friction regarding the ideals of the Protestant

Reformation, the promise of seemingly endless earnings held an added appeal for both entrepreneurial merchants and unemployed workers. ${ }^{16}$ If, as has been suggested, the Revolution gave birth to such a thing as an "American” way of war, then surely its sinews included profits. ${ }^{17}$

\subsection{CONVERTING TRADE ROUTES INTO SUPPLY LINES}

To understand the conversion of the fishing industry, we must begin with the meeting of the Continental Congress convened in Philadelphia first in September 1774, and then again in May $1775{ }^{18}$ This governing body consisted of the educated, wealthy colonial elite, who were elected to represent the interests of the thirteen North American colonies. Congress created the Continental Army on June 15, 1775. At this time, Congress officially adopted the Massachusetts forces surrounding Boston and chose a Virginian planter and slave owner as commander in chief

“The 'New' American Military History: A Map of the Territory, Explored and Unexplored," American Quarterly, Vol. 36, No. 3 (1984), 389-418. To date, no one has systematically examined this issue from commercial fishermen's perspectives.

${ }^{16}$ For arguments resting more in the realm of ideas, see Nathan O. Hatch, The Sacred Cause of Liberty: Republican Thought and the Millennium in Revolutionary New England (New Haven: Yale University Press, 1977); Bernard Bailyn, The Ideological Origins of the American Revolution (Cambridge: Harvard University Press, 1967); and Carl Bridenbaugh, Mitre and Sceptre: Transatlantic Faiths, Ideas, Personalities, and Politics, 1689-1775 (New York: Oxford University Press, 1962).

${ }^{17}$ For a good overview of the military scholarship devoted to studying the "American" way of war, see Don Higginbothom, "The Early American Way of War: Reconnaissance and Appraisal,” The William and Mary Quarterly, $3^{\text {rd }}$ Ser., Vol. 44, No. 2 (April, 1987), 230-273. For studies of the sinews of war within the context of early modern England, see John Brewer, Sinews of Power: War, Money and the English State, 1688-1788 (Cambridge: Harvard University Press, 1990); and Charles Wilson, Profit and Power: A Study of England and the Dutch Wars (London: Longmans, Green and Co., 1957). In an American context, E. James Ferguson examined the ways in which concerns over the size and cost of government during the war later impacted the political debates over the Constitution. Ferguson, The Power of the Purse: A History of American Public Finance, 1776-1790 (Chapel Hill: University of North Carolina Press, 1961). However, his focus was on state expenditures and not on commerce and military mobilization. For an argument that classical republican disdain for monetary incentives pervaded the administrative history of the American Revolutionary War, see Carp, To Starve the Army at Pleasure.

${ }^{18}$ To date, the most comprehensive work done on the Continental Congress remains Edmund Cody Burnett, The Continental Congress (New York: MacMillan Company, 1941). 
in order to assuage fears that the war would be fought solely to promote New England's interests. The Army was not effectively established, however, until George Washington arrived at Boston on July 2. ${ }^{19}$ Thus, for the first half of 1775 the Massachusetts Provincial Congress financed and organized military resistance to British authority.

Massachusetts’ bicameral legislature went through drastic changes between 1774 and 1775. In 1774 councilors appointed by royal writ of mandamus displaced the upper house of the General Court in order to reinforce the authority of the royal governor. In response, the popularly elected lower house, the House of Representatives, separated itself and met variously and illegally in Salem, Concord, and Cambridge, under the title Provincial Congress. In 1775 the Provincial Congress set up permanent shop "at the Meeting-House in Watertown," the epicenter of the Massachusetts forces laying siege to Boston and later General Washington's headquarters. ${ }^{20}$ Following the first military engagements of the war in April at Lexington and Concord, alarms were given and minutemen from the surrounding countryside gathered and bottled up the British forces quartered in Boston. Over the next month, the Massachusetts men dug in and fortified positions around the port city, including Breed's Hill to the north. The creation of the minutemen, their military service at the sound of alarms, and their gathering around Boston all occurred under the direction of the Massachusetts Provincial Congress. On June 20, three days after the battle of Bunker Hill, this political body called on nearby towns to choose representatives for a special election. These representatives then selected men to serve

\footnotetext{
${ }^{19}$ Higginbothom, The War of American Independence, 85, 98.
}

${ }^{20}$ JHRM, Vol. 51, Part I, 271; and JEPCM, i-iii. 
on a Council that was to re-establish Massachusetts' bicameral government. Following the election, the House maintained 236 members and the Council 28 members. $^{21}$

The Massachusetts Provincial Congress formed many sub-committees in order to manage the revolutionary movement that had exploded throughout the region. The Committee of Supplies, for example, was formed in 1774 in order to gather military stores and provisions in the event that armed conflict should erupt between the colonists and the British military. ${ }^{22}$ Wealthy, politically powerful fish merchants such as Jeremiah Lee (1721-1775) and Elbridge Gerry (17441814) served on this committee. ${ }^{23}$ Lee was the son of a wealthy judge and fish merchant. He served as Justice of the Peace, continued his father's business as a fish exporter, and was commissioned Colonel of Marblehead's militia in 1751, a post he would not relinquish until his death. He sat on the Marblehead committee of correspondence; he represented the port town at the Massachusetts Provincial Congress; and he was elected to represent Massachusetts at the Continental Congress. Lee owned, at one time or another, 45 ships, brigs, snows, sloops, and schooners. At his death, he left an estate valued at £24,583.18.10. ${ }^{24}$ He also built and owned

\footnotetext{
${ }^{21}$ See, Cornelius Dalton, John Wirkkala, and Anne Thomas, Leading the Way: A History of the Massachusetts General Court, 1629-1980 (Boston: The Office of the Massachusetts Secretary of State, 1984), 41-48; and JHRM, Vol. 51, Part I, x-xii.

${ }^{22}$ The term "military stores" is used here and throughout the chapter to refer to ammunition, chiefly gunpowder, for use in making cartridges and for cannon fodder; flints, for flintlocks; lead, for making musket balls and artillery shot; and arms, including artillery pieces and hand weapons. "Provisions," on the other hand, is used to signify food supplies such as fish, beef, pork, flour, corn, etc.

${ }^{23}$ For evidence that Lee had been chosen for this particular committee, see the entry for May 14, 1775 in JEPCM, 224; and "Elbridge Gerry, For the Massachusetts Committee of Supplies, to Joseph Gardoqui and Sons, Bilbao, Spain, Watertown, July 5, 1775,” in NDAR, Vol. 1, 818. For Gerry, see the entry for February 9, 1775 in JEPCM, 91; and the "Contract between the Massachusetts Committee of Supplies and Jacob Boardman and others of Newburyport,” June 14, 1775, NDAR, Vol. 1, 678-679, and the abovementioned 818.

${ }^{24}$ For biographical accounts of Lee, see Thomas Amory Lee, “The Lee Family of Marblehead,” Essex Institute Historical Collections, Vol. LII-LIII, (Salem, MA: Newcomb and Gauss, 1916, 1917), 33-48, 145-160, 225-240, 329-344; 65-80, 153-168, 257-287; and the sketch in Phillip Chadwick Foster Smith, ed., The Journals of Ashley Bowen (1728-1813), Vol. 2, (Portland, Maine: The Colonial Society of Massachusetts, 1973), 665.
} 
one of the largest mansions in all of the North American colonies. ${ }^{25}$ He died suddenly on May $10,1775 .^{26}$

Gerry, a Harvard graduate, was, like Lee, a proprietor of a fish exporting merchant house inherited from his father. Dr. Benjamin Rush referred to Elbridge Gerry as “a respectable young merchant, of a liberal education and considerable knowledge. He was slow in his perceptions and in his manner of doing business, and stammering in his speech, but he knew and embraced truth when he saw it."27 Elbridge served as a selectman in Marblehead; a member of the port's committee of correspondence; and a representative to the Massachusetts Provincial Congress. He also signed the Declaration of Independence as a representative to the Continental Congress. $^{28}$ Fish merchants such as Lee and Gerry would use their overseas commercial

\footnotetext{
${ }^{25}$ The mansion "was designed by English architects, and cost more than 10,000 Pounds Sterling. It was stated in the Boston papers of the time that this was 'the most elegant and costly furnished home in the Bay State Colony.' Four Presidents of the United States, including Washington, and also the Marquis de Lafayette, have been among its many guests.” Lee, “The Lee Family of Marblehead,” Vol. LII, 331. The English poet Longfellow dedicated a poem to the mansion upon one of his visits.

${ }^{26}$ Smith describes the extraordinary circumstances surrounding Jeremiah’s death: "on the night of April 19, 1775 he, Azor Orne, and Elbridge Gerry, who had met on committee [the Provincial Congress's Committee of Safety and Supplies] business, passed the night at Wetherby's Black Horse Tavern on the road to Concord. During the night British troops entered the tavern to make a search, and the Marbleheaders were forced to flee in their nightshirts for sanctuary in an adjacent cornfield. As a result of his exposure, Lee contracted a fever and died three weeks later on May 10, 1775.” Smith, ed., The Journals of Ashley Bowen (1728-1813), Vol. 2, 665. Thus, the fishing industry lost a powerful advocate, and the Patriot cause lost a wealthy financier.

${ }^{27}$ See, "Sketches of the signers of the Declaration of Independence by Benjamin Rush, c. 1800," in Henry Steele Commager and Richard B. Morris, eds., The Spirit of Seventy-Six: The Story of the American Revolution As Told By Participants, 4th ed., (New York: Da Capo Press, 1995), 275.

${ }^{28}$ Biographies of Elbridge Gerry, who eventually became Vice President of the United States under James Madison, include George Athan Billias, Elbridge Gerry: Founding Father and Republican Statesman (New York: McGraw Hill Book Co., 1976); Samuel E. Morrison, “Elbridge Gerry, Gentleman-Democrat,” New England Quarterly, II (1929), 6-33; and James T. Austin, The Life of Elbridge Gerry, With Contemporary Letters, To The Close of the American Revolution (Boston: Wells and Lilly, 1828). Also, see the short biographical sketches in Clifford K. Shipton, Sibley's Harvard Graduates (Cambridge: Harvard University Press, 1970), 239-259; and Smith, ed., The Journals of Ashley Bowen (1728-1813), Vol. 2, 654. The editors of George Washington's papers maintain that Gerry "was appointed to the committee of supplies on 9 Feb. 1775." PGW, Vol. 1, 212n. However, according to Gerry, he acted in that capacity from at least as early as December, 1774. Compare "Joseph Gardoqui \& Sons to Jeremiah Lee, Bilbao, February 15, 1775," NDAR, Vol. 1, 401; with "Elbridge Gerry, for the Massachusetts Committee of Supplies, to Joseph Gardoqui and Sons, Bilbao, Spain,” Watertown, July 5, 1775, NDAR, Vol. 1, 818.
} 
connections to facilitate the transfer of much needed military stores to the North American colonies.

Gunpowder was one of the most sought-after military stores. Even prior to the outbreak of war both the colonists and British officials realized that armed resistance of any sort could not succeed without gunpowder. Parliamentarians directly ordered General Thomas Gage to send companies of British regulars into the countryside surrounding Boston in order to remove caches of colonial powder. ${ }^{29}$ At the same time, the British state directed its Navy under Vice Admiral Samuel Graves to stop vessels on the high seas and confiscate any powder thought to be headed into colonial hands. ${ }^{30}$ One colonial merchant later wrote "the Ministry in Britain have been endeavoring to keep a Supply of powder from the Colonies, well knowing that they cannot enslave them by any other Means.”31 For their part, the colonists attempted to get their hands on as much powder as they could despite the efforts of the British state.

As early as December 1774 the Committee of Supplies began negotiating the purchase of military stores through Spain. Initially, the Spanish monarchy was unwilling to support the colonies openly and thereby risk war with Great Britain. There was, however, no love lost between the two European powers. After all, the British were largely responsible for defeating Spain's ambitions in Florida in 1763, a British settlement in the Falkland Islands seemed to threaten Spanish South America in 1770, and there was no small amount of religious animosity between the Protestant and Catholic empires. ${ }^{32}$ Thus, the Spanish government did not take steps

\footnotetext{
${ }^{29}$ Higginbothom, The War of American Independence, 29-53.

${ }^{30}$ Buel, Jr., In Irons, 31-32.

31 "Elbridge Gerry, for the Massachusetts Committee of Supplies, to Joseph Gardoqui and Sons, Bilbao, Spain," Watertown, July 5, 1775, NDAR, Vol. 1, 818.

${ }^{32}$ Jonathan R. Dull, A Diplomatic History of the American Revolution (New Haven, Conn.: Yale University Press, 1985), esp. 28-30.
} 
to forcibly prohibit trade with the North American colonies at the start of war. ${ }^{33}$ This tacit support opened the door to entrepreneurial merchants who were willing to take the risks of wartime trade and to sell covertly all sorts of goods at inflated prices. ${ }^{34}$ Fish merchants played leading roles in importing and exporting military stores during the American Revolution.

The most important Spanish merchant house involved in the Atlantic fish trade with New England belonged to the Gardoqui family. ${ }^{35}$ Joseph Gardoqui and his sons operated out of Bilbao, Spain. While most Iberian merchants maintained commercial ties to West Country businessmen in England who controlled the Newfoundland fisheries, the Gardoquis developed a transatlantic commercial network, exchanging salt, fruits, wine, and lines of credit for shipments of merchantable grades of dried cod from Massachusetts. Bills of exchange were then deposited in accounts with English merchants, mostly in London. Finally, manufactured goods were purchased in England and brought back to the colonies. ${ }^{36}$ The Gardoquis also provided colonial merchants with much needed information regarding the prices of various goods, including the demand for dried cod. Indeed, commercial ties between colonial fish merchants and the Gardoqui house were so strong that in 1763 Jeremiah Lee named a ship of 110 tons burden that

33 “Brigadier General Nathanael Greene to Nicholas Cooke,” Rhode Island Camp, Jamaica Plains, June 28, 1775, NDAR, Vol. 1, 769.

${ }^{34}$ Spanish merchants on the eve of the American Revolution may have also held out hopes for lucrative war time contracts in the event colonial Americans rebelled against Britain. At the beginning of 1775, one colonial fish merchant and member of the Massachusetts Provincial Congress had this response to a Spanish merchant's offer of providing military stores in trade: "The Friendship of foreign Factors in this Matter cannot fail of making them respectable \& securing to themselves the Interest of these Colonies." The Provincial Congressman further noted that the colonists would "cheerfully allow such a Compensation for your Services as You shall think reasonable." "Elbridge Gerry, for the Massachusetts Committee of Supplies, to Joseph Gardoqui and Sons, Bilbao, Spain," Watertown, July 5, 1775, NDAR, Vol. 1, 818.

${ }^{35}$ Reyes Calderón Cuadrado, Empresarios españoles en el proceso de independencia norteamericana: La casa Gardoqui e hijos de Bilbao (Madrid: Unión Editorial, 2004). Thomas E. Chávez discusses the Gardoquis only briefly in a more accessible study. Thomas E. Chávez, Spain and the Independence of the United States: An Intrinsic Gift (Albuquerque, NM: University of New Mexico Press, 2002), 15, 61, 68, 85, 220.

${ }^{36}$ See, Joseph Swett Jr. and Robert Hooper Jr. fonds, 1740-1747, MUMHA; Richard Derby Ledger, 1757-1776, JDPL; William Knight Account Book, 1767-1781, JDPL; Richard Pedrick Account Book, 1767-1784, MDHS; and Daniel Rogers Account Book, 1770-1790, JDPL. 
he used to transport dried cod to Bilbao the Gardoqui, in honor of his esteemed trading partners. $^{37}$

Early on, the Gardoquis sympathized with the colonials in their grievances with the British state. On February 15, 1775, months prior to the outbreak of armed hostilities, the Spanish merchants expressed their support in a letter to Jeremiah Lee and the Massachusetts Committee of Supplies. The Gardoquis were "determined at all events to assist you accordingly.” They explained: "We see with the utmost concern the difficulties You labor under by an unpolitical Minister's wrong direction of Affairs, But hope the Present Parliament will look into them with clearer light, \& will find proper means to accommodate Matters, without going any further, allowing you your just Rights \& Liberties, which we do assure you we long to see it settled with all our hearts; but should it be otherwise (God forbid) command freely and you will find us at your service." The Gardoquis closed with "We hourly look out for the London Post, should it bring any thing Worth y[ou]r notice, you may depend on being advised.”38 Thus, the Spanish merchants committed themselves to aiding the colonial cause even before the outbreak of war. Indeed, in 1777 Lord Grantham, the British Minister at Madrid, observed "the House of Gardoqui is very active. They have long had connection with Great Britain and America, but in the present contest, though they pretend to wish it was ended, they have adhered to the latter with great partiality.”39

The “partiality” that Grantham observed included the Gardoquis sending military stores to the colonies along with news of British troop movements. On December 16, 1774, four

\footnotetext{
37 "A List of Vessels that have cleared outwards in the ports of Salem \& Marblehead between the 10th of October 1763 \& the 5th of January following being the quarter ending at Christmas..." Massachusetts Shipping Records, 1686-1765, Part III, pp. 916-1143, Box 3, MHS.

38 “Joseph Gardoqui \& Sons to Jeremiah Lee, Bilbao, February 15, 1775,” NDAR, Vol. 1, 401.

${ }^{39}$ Quote cited in Cuadrado, Empresarios españoles en el proceso de independencia norteamericana, 188.
} 
months before the shot heard around the world, Jeremiah Lee wrote to the Gardoquis to explicitly suggest the Spanish merchants help the colonists acquire military stores from Europe. While Lee's letter has not survived, the Gardoquis responded that they had looked into "the method of complying with your orders...to procure as many Muskets \& pistols as were ready made...for the King’s Army.” The Spanish merchants had been able to acquire "300 Muskets \& Bayonets, \& about double the number of Pair of Pistols.” They further agreed to do "our utmost to get as many more as was to be found in order to serve you, \& shall whenever you should command." Lee and the committee must have also requested access to gunpowder, as the Gardoquis wrote: "The Powder is an Article which we cannot ship unless we have timely advice, for whatever there is made in this Kingdom is for the Government." ${ }^{40}$ Gerry and the Committee of Supplies then sent "the Rockingham [Gerry's vessel], Capt[ain] Johnson w[i]th $£ 1000$ Ster[lin]g in Cash, \& six Hundred \& fifty pounds Bills of Exch[ang]e on your House to be invested in good pistol \& Cannon powder - half each.”" ${ }^{11}$ On March 27, 1776, “Joseph Gardoqui and sons” sent a letter by ship to Massachusetts (it took twenty-nine days), to Newburyport, Salem, and finally Watertown, where it ended up in the hands of the General Court. The letter stated: "No other news from England, but that 17,300 German troops were going to Boston and Canada, some of which embarking about 3 weeks ago.”42 In this manner, a preexisting transatlantic trade network involving the exchange of commercial information and merchantable grade dried cod was converted to the transfer of arms, ammunition, and military intelligence.

40 “Joseph Gardoqui \& Sons to Jeremiah Lee, Bilbao, February 15, 1775,” NDAR, Vol. 1, 401.

41 "Elbridge Gerry, for the Massachusetts Committee of Supplies, to Joseph Gardoqui and Sons, Bilbao, Spain," Watertown, July 5, 1775, NDAR, Vol. 1, 818. The Rockingham was eventually seized by the British Navy and its goods confiscated. See, Elbridge to Samuel Gerry, May 21, 1776, Elbridge Gerry Papers to 1780, MHS.

${ }^{42}$ Quote cited in Cuadrado, Empresarios españoles en el proceso de independencia norteamericana, 187. 
Similarly, the more active South Atlantic commercial networks involving the exchange of refuse grade dried cod were also transformed for war.

Prominent fish merchants were able to convert well-worn trade routes to the West Indies into military supply lines. ${ }^{43}$ In June, 1775, Elbridge Gerry and the other members of the Committee of Supplies signed a legal contract with “Jacob Boardman Merchant, John Harbert Blockmaker, and Joseph Stanwood Mariner all of Newbury Port in the County of Essex.” The contract was to hire "the good Schooner, nam'd the Britaniae of the Portlage or Burthen of Eighty-Eight Tons, now laying in the Harbor of said Newbury Port, whereof Abel Coffin is at present Master." The schooner was hired "for a Voyage or Voyages...to all or any of the West India Islands, and directly back to any Part of New England.” A provision was added to the contract formally acknowledging "the said Vessel shall be liable or subject to any Seizure, Detention or Confiscation.” In order to mitigate the Newport merchants' war-time shipping risks, the committee agreed that the Massachusetts Provincial Congress would be legally responsible for "the Sum of Four Hundred Pounds in full for the Value and worth of the said Schooner, and also the Freight money," which amounted to "the Rate of Twenty three Pounds nine shillings and four Pence, for each and every Calendar Month.”44 Moreover, in the following month Gerry and the committee arranged for "One hundred \& twenty hogsheads Fish, besides Boards, Shingles" to be shipped on board an unnamed brig from Newburyport to the Windward islands in the West Indies. Merchants from Marblehead, Gloucester, and Beverly delivered the fish to Newburyport "free of Charge." There, Captain Michael Corbet, who had

\footnotetext{
${ }^{43}$ Richard Pares has studied the conversion of trade routes between British North America and the British West Indies into military supply lines for an earlier period. See, Richard Pares, War and Trade in the West Indies, 17391769 (Oxford: Oxford University Press, 1936). To date, there has been no book-length study of a similar conversion during the Revolution.

${ }_{44}$ "Contract between the Massachusetts Committee of Supplies and Jacob Boardman and others of Newburyport, June 14, 1775,” NDAR, Vol. 1, 678-679.
} 
gained fame for resisting British Naval impressment in Marblehead's harbor during the Pitt

Packet affair in 1769, was ordered to sell this cargo and obtain as much gunpowder, "an Article, so immediately necessary," as he could among the tropical islands. Gerry and the other members of the Committee felt that "the Prosecution of the Scheme in all its Parts, might lay a Foundation for some eminent Services in future." ${ }^{45}$ In October, 1775, the Continental Congress recommended each colony/state export provisions to the West Indies in order to trade for military stores. ${ }^{46}$ But this was after the fact that colonies such as Massachusetts were already conducting such trade.

Fish merchants were not the only ones to send trade ships to the Caribbean for military stores. Flour and rice merchants, in Pennsylvania and South Carolina, also had commercial ties to the West Indies, and they too drew upon their connections to gather military supplies. ${ }^{47}$ Shippers hid gunpowder in hogsheads topped with sugar, coffee, or some other West Indian trade good. $^{48}$ In this way, those vessels the British Navy stopped and inspected stood a chance of

\footnotetext{
45 “Tristam Dalton to Elbridge Gerry,” Newburyport, July 23, 1775, NDAR, Vol. 1, 953-954. For more on Corbet and the Pitt Packet affair, see Christopher P. Magra, “'Soldiers...Bred to the Sea': Maritime Marblehead, Massachusetts and the Origins and Progress of the American Revolution,” New England Quarterly, Vol. LXXVIII, No. 4, (December 2004), 531-562. By August, Gerry reported to Washington: "We are in daily Expectation of some Powder from the West Indies, but cannot say what Success our plans will meet with.” Elbridge Gerry and the Massachusetts Committee of Supplies to George Washington, Chamber of Supplies, Watertown, August 1, 1775, PGW, Vol. 1, 211.

${ }^{46}$ JCC, Vol. 1, 158.

${ }^{47}$ See, for example, NDAR, Vol. 1, 949, 1013. More work needs to be done on the relationship between these industries and the war effort.

${ }^{48}$ NDAR, Vol. 1, 1265-1266. Also, on July 21, 1775, Patrick Tonyn, Governor of British Florida, wrote from St. Augustine to Lord Dartmouth that an informer "Gave this moment this intelligence: That he saw delivered at Charleston in [South] Carolina, a number of Sugar Hogsheads, that actually came from Jamaica, that, the Hogsheads were filled all with Gunpowder, that he actually saw the Hogshead open, and the Gunpowder....that it has been constantly run from Jamaica to Charleston, in that way, and from many other of the West India Islands.” Ibid., 949. Similarly, Lord William Cambell, Governor of South Carolina, wrote from Charleston to Lord Dartmouth on July 19, 1775 to say "Every hour I have the Mortification of hearing of Vessels from the Dutch and French Settlements arriving, and smuggling their Cargoes in the neighboring Creeks; and three Schooners that were loaded with Rice a few days before my Arrival, and sent to Hispaniola for the professed purpose of bringing back Military Stores, are every moment expected.” Ibid., 929. J. F. Jameson observed that Dutch merchants smuggled military stores to the West Indies "disguised in tea-chests, rice barrels, and the like." J.F. Jameson, "St. Eustatius in the American Revolution,” The American Historical Review, Vol. 8, No. 4 (July, 1903), 688.
} 
evading capture. Throughout much of the war, South Carolina was able to supply the New England colonies with provisions, mostly rice, and imported military stores. ${ }^{49}$

Both overseas merchants and colonial entrepreneurs grew wealthier in trading for military stores. At the end of July, the Continental Congress allocated fifty thousand dollars to "be paid by the continental treasurers," to merchants in New York and Philadelphia, "to be by them applied to the purpose of importing gunpowder for the continental armies.” The exporters were allowed a "five per Cent" commission rate "for their trouble and expenses therein."50 Congress allowed the same five percent commission to purchasing agents in the West Indies. ${ }^{51}$ The aggressive pursuit of profits that pervaded in the Atlantic world was bent to the way of war.

Such incentives successfully encouraged merchants to export trade goods and motivated purchasing agents to negotiate deals abroad. In July alone, it was estimated that between five and six-and-a-half tons of powder entered Philadelphia from St. Eustatia. ${ }^{52}$ At the same time, another seven thousand pounds of powder entered Philadelphia, and five thousand pounds entered New Jersey. ${ }^{53}$ Washington himself believed "there are few Colonies who have not some Vessel out on this Errand [i.e. trading for gunpowder], and will probably bring all that is at Market."54 In 1776 alone, 69,000 pounds of gunpowder left the West Indies for the mainland

${ }^{49}$ Buel, Jr., In Irons, 25-26.

${ }^{50}$ JCC, Vol. 2, 210-211.

${ }^{51}$ Robert Greenhalgh Albion and Jennie Barnes Pope, Sea Lanes In Wartime: The American Experience, 17751942 (New York: W.W. Norton and Company, Inc., 1942), 51-52.

${ }^{52}$ For the estimate of five tons, which was provided by an unnamed British colonial official to Philip Stevens, the Secretary of the British Admiralty Board, dated Philadelphia, July 30, 1775, see NDAR, Vol. 1, 1013. For the higher estimate, which was recorded in the official journal of the Continental Congress, see JCC, Vol. 2, (Washington, D.C.: U.S. Government Printing Office, 1905), 204. Richard Henry Lee, one of Virginia’s delegates to the Constitutional Convention, wrote to Washington to report the shipment of "six Tons" of powder to Boston. Richard Henry Lee to George Washington, Philadelphia, August 1, 1775, PGW, Vol. 1, 209.

${ }^{53}$ See the letters from John Adams to James Warren, dated July 24 and July 27, 1775, NDAR, Vol. 1, 964-965, 992; JCC, Vol. 2, 238; and Richard Henry Lee to George Washington, Philadelphia, August 1, 1775, PGW, Vol. 1, 209.

54 “George Washington to Nicholas Cooke, Deputy Governor of Rhode Island,” Camp at Cambridge, August 14, 1775, NDAR, Vol. 1, 1138. 
colonies. ${ }^{55}$ By the end of 1777, 1,454,210 pounds of gunpowder had been imported into the colonies for the Continental Army’s use from overseas. ${ }^{56}$

Building on the successes of these voyages, a plan was laid for sending a fleet of trade vessels laden with dried cod from Massachusetts to the West Indies in order to obtain military stores. In December, 1775, the General Court ordered the Committee of Supplies: "to engage and fix out with all possible dispatch, on the Account and Risk of this Colony, Ten Vessels, to be laden with as much Provision [i.e., dried cod], Horses, or any other produce of this Colony, except horned Cattle, Sheep, Hogs and Poultry, as they may deem necessary for the importation of Ammunition, Sulfur, Salt-Peter, Arms and German-Steel, for the manufacturing Gun-Locks, \&c. And that the said Committee be empowered to give Orders to the Commander of every such Vessel to export the said Cargo to the foreign West-Indies, for the Purposes aforesaid."57 The Court then "put into the Hands of the Committee...the Sum of Eight Thousand Pounds."58 Some of this enormous investment was surely meant to compensate the committee members for their efforts. This investment, like so many others, allowed colonial fish merchants to utilize their commercial connections around the Atlantic to obtain much needed military stores. Without the fish, the preexisting networks of trust, and the promise of profits, obtaining these stores and prosecuting the war effort would have been much more difficult.

The British Navy went to great lengths to stop colonists from importing military stores, particularly gunpowder. On July 5, 1775, General Gage communicated to Vice Admiral Graves his concern regarding "the Endeavors of the Rebels to procure Powder." Gage informed the

\footnotetext{
55 Jameson, "St. Eustatius in the American Revolution," 688.

${ }^{56}$ O. W. Stephenson, "The Supply of Gunpowder in 1776," American Historical Review, Vol. 30, No. 2 (January, 1925), 271-281.

57 JHRM, Vol. 51, Part II, 45-46.

${ }^{58}$ JHRM, Vol. 51, Part II, 121.
} 
admiral that "within these few Days they have received 37 half Barrels which was brought from New Haven in Connecticut, where it was imported from St. Eustatia.”59 The genial Graves attempted to put a positive spin on matters, responding immediately: "I am happy to find they are in want of Ammunition.” In order to explain the situation to the General, the Admiral listed the number of ships under his command and their location. He then wrote: "I anxiously hope to hear that some of them are successful in seizing the Rebel's Supplies, as their Captains are under the strictest Orders to be vigilant, and I omit no occasion of sending Them every information I can procure for their Guidance.”60 For example, on July 5, 1775, Graves ordered Captain William C. Burnaby, commander of the H.M.S. Merlin, to cruise "between Cape Anne and Cape Cod [the location of the principal fishing ports in New England], anchoring occasionally at Marblehead or Salem," and also at times "to extend your Cruise to the Isle of Shoals or Piscataqua River." He was especially to "Examine the Bay of Salem and the Harbors therein, in order if possible to prevent every Kind of Supply getting to the Rebels by Sea." ${ }^{61}$ The British Navy did stop some of the trade in fish for military stores. On August 9, 1775, "two schooners from the West-Indies" attempted to steal into Salem. The H.M.S. Falcon, John Lindsay, Captain, captured one of the schooners and chased the second into Salem's harbor, where he was forced to retreat by colonial forces. ${ }^{62}$ But, for the most part the fish colonists caught and processed at the beginning of 1775 was successfully exchanged for military stores. Even Graves had to admit that "On this extensive Coast some Supplies will get in, but I hope in no great Quantities.”63

\footnotetext{
59 “General Thomas Gage to Vice Admiral Samuel Graves,” Boston, July 5, 1775, NDAR, Vol. 1, 819.

60 "Vice Admiral Samuel Graves to General Thomas Gage," Boston, July 5, 1775, NDAR, Vol. 1, 819-820.

61 "Vice Admiral Samuel Graves to Captain William C. Burnaby, R.N.,” July 5, 1775, NDAR, Vol. 1, 820.

62 "A Letter from Gloucester, Cape Ann, to Isaiah Thomas, Worcester," Gloucester, August 13, 1775, NDAR, Vol. 1, 1132-1133.

63 "Vice Admiral Samuel Graves to General Thomas Gage," Boston, July 5, 1775, NDAR, Vol. 1, 819. As late as 1777, John Montagu, the Earl of Sandwich and Lord of the Admiralty during the Revolution, echoed Graves' earlier sentiments in a letter to Lord North. Montagu wrote: "It must not, however, be imagined that any force will
} 
In the West Indies, Vice Admiral James Young, commander of the British Naval Squadron positioned to police the region, knew that New England fish merchants were obtaining military stores on his watch. On August 30, 1775, Young wrote to Philip Stevens, the Secretary of the British Admiralty Board, "that a Schooner from North America arrived at the Island [of] St. Croix, in Order to procure Gunpowder for America; and offering any Money for the Purchase \&c, and it having since then been intimated to me by Persons of Credit, at this place, that it is believed The North American Traders do procure Gunpowder and other Warlike Stores from this Island, and His Majesty's other Charibbee Islands, in these Seas, as well as from the French, Dutch, and Danish Islands.”64 The Vice Admiral ordered the vessels under his command to watch for vessels "bound to North America” laden with “Gunpowder or other Warlike Stores.”65 He then wrote to "the President and Members of the Council at Antigua" to warn them that “sundry Vessels belonging to North America go to the French, Dutch \& Danish Islands in these Seas, \& offer unlimited prices for Gunpowder \& other Warlike Stores.” Young was “fearful the vast price offered may tempt the Proprietors to run risks \& dispose of it, which must prove of the utmost disservice to His Majesty by thus assisting the North Americans, who are now declared to be in open Rebellion."66 ${ }^{6}$ Yet despite the tentative measures he took, Young remained fearful. In his own words, he stated, "During the present Hurricane Season I can do little more with the

be sufficient entirely to execute the purpose of blocking up all the rebels' ports and putting a total stop to their privateering; for along so extensive a coast, full of harbors and inlets, many ships will, in spite of all our efforts, get in and out by taking advantage of their knowledge of the coast, of dark and long nights, and events of wind and weather favorable to their purposes.” Quoted in Albion and Pope, Sea Lanes In Wartime, 37.

64 "Vice Admiral James Young to Philip Stevens, Secretary of the British Admiralty," Portland, English Harbor, Antigua, August 30, 1775, NDAR, Vol. 1, 1267.

65 "Vice Admiral James Young to the Captains of His Majesty’s Sloops Lynx and Pomona," Portland, English Harbor, Antigua, August 14, 1775, NDAR, Vol. 1, 1148.

66 "Vice Admiral James Young to the President and Members of the Council at Antigua," Portland, English Harbor, Antigua, August 14, 1775, NDAR, Vol. 1, 1148-1149. 
King’s Ships under my Command, then sending them to the Southern Islands for Security., Such timid leadership, North America's expansive coastline and numerous harbors, and colonial merchants' commercial connections, made it possible for Patriots to secure military stores at the beginning of the war. ${ }^{68}$

\subsection{REGULATING FOOD SHIPMENTS}

The exportation of food stuffs of any kind, including dried cod, posed a dilemma for colonial leaders at the start of the war. On the one hand, they wanted to import military stores, and shipments of provisions had been traditionally used in trade with the West Indian slave plantations. One the other hand, colonial leaders were nervous about provisions being sold to intermediaries, who would then turn around and supply the British forces at Boston, whom they were attempting to starve into leaving. Moreover, colonial merchants hoped that cutting-off supplies to Newfoundland would put economic pressure on West Country merchants, who would in turn lobby Parliament to end the war. Because of these needs and concerns, dried cod

\footnotetext{
67 "Vice Admiral James Young to Philip Stevens, Secretary of the British Admiralty,” Portland, English Harbor, Antigua, August 30, 1775, NDAR, Vol. 1, 1268.

${ }^{68}$ For more on the inability of the British Navy to stop military supplies from entering colonial north American ports during the opening salvo of the Revolution, see Syrett, "Defeat at Sea," 13-22; Miller, Sea of Glory, 22-38; Albion and Pope, Sea Lanes In Wartime, 34-64; and Stephenson, “The Supply of Gunpowder in 1776,” 271-281. According to Syrett, a combination of factors, including the fact that the British reserved naval power to defend against possible French and Spanish invasion; the British Naval leadership derisively discounted the need for naval power in the American theater; the North American coast is enormously long and contains numerous inlets and harbors; and the distractions associated with assisting army operations and fending-off colonial attacks at sea occupied naval attention, all "made the maintenance of an effective blockade of the American coast impossible." Syrett, "Defeat at Sea," 13-15. More recently, Buel, Jr., has demonstrated the British Navy's increasing success in the later war years at stopping the flow of goods into and out of the colonies. In particular, he notes that the British Navy stationed in the West Indies became proficient at halting French vessels departing from and bound to colonial North American ports. In Irons, 288, footnote \#27.
} 
continued to flow out of Massachusetts during the Revolutionary War, but fish exports were heavily regulated.

On May 17, 1775, the Continental Congress resolved to prohibit the direct exportation of “provisions of any kind, or other necessaries” to Newfoundland, Nova Scotia, and other northern parts. This prohibition was explicitly meant to increase the cost of doing business for "the British fisheries on the American coasts."69 Yet, a loophole remained in Parliament's Fisheries Bill, by which the Quaker merchants on Nantucket had received a special exemption for their whaling industry. This meant that Nantucket whalemen operating off the coast of Newfoundland could sell provisions to English migratory fishing vessels in the region for inflated war time profits, thereby increasing the ability of the migratory fishing sector to thrive and expanding the likelihood that the New England fishing industry would be replaced by its inter-imperial commercial rival. Nantucket whalemen were also allowed to enter British-controlled ports in the North Atlantic, increasing the risk of colonial provisions ending up in the hands of intermediaries who would then supply the British military in Boston. As a result, Congress further resolved on May 29, 1775, “That no provisions or necessaries of any kind be exported to the island of Nantucket....The Congress deeming it of great importance to North America, that the British fishery should not be furnished with provisions from this continent through Nantucket, earnestly recommend a vigilant execution of this resolve to all committees.”70

These somewhat paranoid regulations made in Philadelphia were then transported to Watertown, Massachusetts, where the Provincial Congress reviewed them on June 9, $1775 .^{71}$ Immediately, the Provincial Congress ordered the printing of hand bills to be "dispersed in the

\footnotetext{
${ }^{69}$ JEPCM, 313.

${ }^{70}$ JEPCM, 313-314.

${ }^{71}$ JEPCM, 313.
} 
several sea port towns in this colony, that due obedience may be paid to the same."72 These bills stated: "Whereas the Enemies of America are multiplying their Cruelties towards the Inhabitants of the New-England Colonies by seizing Provision Vessels, either the Property of, or intended to supply them...Resolved, That it be, and it hereby is recommended to the Inhabitants of the Towns and Districts in this Colony, that they forthwith exert themselves to prevent the Exportation of Fish, and all other Kinds of Provision.,73 Even prior to this official prohibition, the committee of safety in Marblehead made it known in town meetings that supplying the enemy with provisions would not be tolerated. ${ }^{74}$

The Continental Congress did establish an exemption to their prohibition on shipments of provisions to Nantucket. No colony was allowed to supply the Quaker island "except from the colony of the Massachusetts Bay.” The Massachusetts Provincial Congress was "desired to take measures for effectually providing the said island, upon their application to purchase the same, with as much provision as shall be necessary for its internal use, and no more."75 Massachusetts was the only region the Continental Congress allowed to trade with Nantucket because it alone could be trusted. The center of British military operations was in Boston, and Massachusetts was the foremost fishing colony. Massachusetts merchants would sell only the provisions that Nantucket needed for local consumption.

Massachusetts's revolutionary government passed a series of resolves in order to ensure that any provisions shipped to Nantucket were "for the internal use of said island." The Provincial Congress further resolved that no one should be allowed to export provisions to

\footnotetext{
${ }^{72}$ JEPCM, 314.

${ }^{73}$ NDAR, Vol. 1, 608.

${ }^{74}$ Marblehead Town Records, Office of the Town Clerk, Abbot Hall, Marblehead, Massachusetts, 23 January, 14 February, 28 February 1775.

${ }^{75}$ JEPCM, 314.
} 
Nantucket "without a permit in writing from the committee of safety of this colony, or such person or persons as they shall appoint to give such permit."76 As soon as the people of Nantucket began "fitting out a large fleet of whaling vessels" to exploit the Fisheries Bill exemption, as they did in between June and July, the Provincial Congress felt that it was simply too risky to provide provisions. At this point, the Congress resolved on July 8, 1775, "that no provisions or necessaries of any kind be exported from any part of this colony to the island of Nantucket, until the inhabitants of said island shall have given full and sufficient satisfaction to this Congress, or some future house of representatives, that the provisions they have now by them, have not been, and shall not be, expended in foreign, but for domestic consumption.,77 Yet, even this restriction could not allay Congressional fears.

Over the course of the next month, Massachusetts's political leaders continued to fret over the Fisheries Bill exemption and shipping food to Nantucket. In the end, the members of the Provincial Congress resolved that only drastic measures would suffice. On August 10, 1775 they determined that "from and after the $15^{\text {th }}$ Day of August Instant, no Ship or Vessel shall sail out of any Port in this Colony, on any Whaling Voyage whatever, without Leave first had and obtained from the Great and General Court of this Colony." In effect, Massachusetts did to the Nantucket whalers what Parliament had done to the New England cod fishermen. The Massachusetts General Court, or Provincial Congress, communicated this declaration "to the several Assemblies of the other New England Colonies, advising them to pass a similar Resolve.” Then, in order to make sure the general public was aware of the regulation, the Congress ordered its resolve to "be printed in the several News-Papers of Cambridge and Watertown, and in Hand-Bills." They further established a special sub-committee "for getting

\footnotetext{
${ }^{76}$ JEPCM, 314.

${ }^{77}$ JEPCM, 470.
} 
the same Printed and Dispersed to the several Sea Ports in this Colony." Members of the Congress justified this moratorium on whaling and these attempts to raise public awareness by stating the need "to take all possible Precaution that none of the Inhabitants of this Colony supply those who are seeking our Ruin, with Provisions, or any Materials that shall enable them to execute their cruel Designs against us.”78 Colonial political leaders, including the Continental Congress and the Massachusetts Provincial Congress, closed one sector of the coastal trade involving shipments of fish and other provisions, and they shut down one maritime industry. Surely this was done in the interests of military security. Yet, these actions were also meant to prevent the West Country migratory fishing industry from profiting in the North Atlantic at New England's expense. The commercial competition that existed between the West Country and New England fish merchants prior to the war continued during the conflict.

Merchants who wanted to trade provisions for military stores were more fortunate than those who had supplied the whaling industry. To be sure, there were restrictions on colonial exports in general. On October 20, 1774 the Continental Congress adopted the Continental Association, a collective non-importation and non-exportation agreement that prohibited member colonies from receiving goods from areas Great Britain controlled after December 1, 1774. The Association further prevented members from shipping provisions to these areas after September 10, $1775 .^{79}$ Fish, however, was still shipped out of New England ports to overseas foreign markets.

In addition to the incidents of overseas fish exportation discussed above, there is evidence that private, non-governmental fish merchants petitioned the Massachusetts Provincial Congress for special dispensations to ship their particular provision during the war. On June 16,

\footnotetext{
${ }^{78}$ JHRM, Vol. 51, Part I, 60.

${ }^{79}$ NDAR, Vol. 1, 16n.
} 
1775, Ellis Gray and Richard Hinckley, two Massachusetts fish merchants, asked the Provincial Congress for permission to export "eighty hogsheads of Jamaica cod fish, laden on two vessels bound to the West Indies." The petitioners went on to explain that one of the vessels "would have sailed before the resolve of this honorable Congress forbidding the exportation of fish was published, had she not been detained by the elopement of her hands.” ${ }^{80}$

This shipment of fish was likely meant to be exchanged for military stores, as it was in June that Gerry, himself a Marblehead fish merchant, and the Committee of Supplies, had approved the plan to send ten vessels to the West Indies for such stores. Word must have spread among the merchant community that such a plan would receive government sanction. Moreover, merchants must have realized that the availability of foreign military stores among the islands, burgeoning demand in North America for military stores, and inflated prices for provisions in the West Indies meant that huge war-time profits could be made. ${ }^{81}$ According to Selwyn Carrington, the foremost authority on the American Revolution's economic impact on the West Indies, the price of dried cod, or "saltfish," increased by 86.7\% per quintal between 1774-1775 and 1776 in Barbados, one of the largest markets in the British West Indies. In smaller St. Vincent, the price of dried cod increased $300 \%$ between $1770-1774$ and $1778-1784{ }^{82}$ Such price inflation was a

${ }^{80}$ JEPCM, 343. Such mobile mariners recognized that to sign-on for a voyage on a vessel carrying an article Parliament had expressly forbidden meant an increased likelihood that the British Navy would stop and search their vessel, which in turn heightened the possibility of impressment, especially as it was war time.

${ }^{81}$ Dutch St. Eustatius, in particular, became a major free port at which different European powers could sell military stores to North Americans at inflated prices. Jameson, "St. Eustatius in the American Revolution," 683708.

${ }^{82}$ Selwyn H.H. Carrington, The British West Indies During the American Revolution (Providence, RI: Foris Publications, 1988), 111, Table 46b, 113, Table 49. Prices for corn, beef, flour, and pork were also inflated throughout the British West Indies. See, ibid.; and Richard B. Sheridan, "The Crisis of Slave Subsistence in the British West Indies during and after the American Revolution,” William and Mary Quarterly, $3^{\text {rd }}$ Series, Vol. 33, No. 4 (October, 1976), 615-641, esp. 621, Table I. There are no equivalent figures for the French, Spanish, or Dutch West Indies. However, it is very likely that some of the same pressures that drove up prices on all the British West Indian islands during the Revolutionary War, particularly the decline in dried cod production, fears of provision shortages, and the increasingly successful efforts of the British Navy to halt North American commerce, similarly raised the prices of all imported provisions on the other islands. 
direct result of the Revolutionary War, the Continental Association, and Parliamentary prohibitions. Of course, prices for military stores in the West Indies were inflated due to the exigencies of war as well, and this inflation cut into fish merchants' profit margins. ${ }^{83}$ Whether they intended, as the Committee of Supplies certainly did, to exchange their fish for military stores to sell to the Continental Army for a profit, the civilian fish merchants were successful in getting the Massachusetts government to approve their petitions.

On June 16, the Provincial Congress established a sub-committee "to consider what may be done with respect to such vessels as are now ready to sail, with fish on board, there being a resolve of this Congress against the exportation of fish, \&c.” This sub-committee on fish exports included two additional fish merchants from Marblehead: Azor Orne and Jonathan Glover. ${ }^{84}$ The committee members approved the petitions and went so far as to recommend certain measures to the Provincial Congress for establishing a system by which future merchants could export fish, earn inflated war-time prices, and bring in much-needed military stores despite the prohibitory sanctions.

The fish exports committee members had a very specific rationale for approving the petitions. They explained that "the fish those gentlemen were about to export, is of such a kind, being old Jamaica fish, as, if detained, cannot possibly be of any advantage to this colony, but must perish.” Orne and Glover, like other fish merchants, understood the already undesirable nature of refuse grade dried cod. The committee members maintained Massachusetts was, at that time, "plentifully supplied with new fish.” With stores of better grades of cod waiting in flakeyards, drying houses, and warehouses, there simply was no point in detaining a boatload of

\footnotetext{
83 Jameson noted that "it cost in Holland but forty or forty-two florins a hundredweight [for gunpowder], [yet it] brought 240 florins a hundredweight at the island [St. Eustatia].” Jameson, "St. Eustatius in the American Revolution,” 688.

${ }^{84}$ JEPCM, 341.
} 
fish fit only for slaves. And if this refuse fish could bring military stores back to the continent from the islands, then so much the better. Thus, the committee ruled "that permission be given by this Congress, to the owners of said vessels, for their proceeding on their voyages.” ${ }^{\text {. }}$

In order to pave the way for future petitions along these lines, the committee members recommended the establishment of certain guidelines for granting exemptions for fish exportation during the war. They suggested "that toleration be given to all other owners of vessels, for their departure, who shall convince this Congress, or a committee thereof, that their vessels and cargoes are in the same predicament, as no possible advantage can accrue from their detention.” ${ }^{86}$ The sub-committee’s recommendations were formally adopted, and one week later the Provincial Congress approved the petition of Winthrop Sergeant, a fish merchant from Gloucester, Massachusetts, who wanted "to ship off for the West Indies, a quantity of old Jamaica fish, not exceeding forty hogsheads.” The language the Provincial Congress used in their approval mirrored the sub-committee’s prior recommendation. The Provincial Congress stated that it appeared "to this Congress that the said fish, if stopped, will be of little or no service to this colony.”77 Thus, fish merchants from Marblehead wrote official government policy during the war and helped create an avenue by which the quest for profits could potentially benefit the colonial cause by bringing in military stores from the West Indies.

The Massachusetts exemption for allowing the exportation of refuse grade dried cod was linked explicitly to the importation of military stores in the Continental Congress. On July 15, 1775, Ben Franklin, himself a great supporter of Philadelphia's trade in bread and flour to the West Indies, got passed an exemption allowing all merchants, from any colony, "to load and

\footnotetext{
${ }^{85} \mathrm{JEPCM}, 343$.

${ }^{86}$ JEPCM, 343.

${ }^{87}$ JEPCM, 382-383.
} 
export the produce of these colonies [later stated "produce of any kind"], to the value of such powder and [military] stores aforesaid, the non-exportation agreement notwithstanding.” A copy of this resolution was then printed in the form of hand bills and sent to the West Indies in order to reassure buyers in the region that they could rely on North American shipments. ${ }^{88}$ This exemption made it acceptable for American merchants to ship provisions to all markets provided they trade for military stores. As early as 1774 Parliament had forbidden loyal members of the British Empire to import goods from the rebelling colonies. At the same time, the British state expressly prohibited anyone from exporting military stores to the colonies without "a License from his Majesty, or the Privy Council for the exportation thereof from Great Britain.”89 Franklin's exemption, however, effectively removed any legal/political obstacle from the American side, and the West Indian planters became increasingly desperate for provisions and ever more fearful of slave revolts as the war dragged on. ${ }^{90}$ Thus, dried cod, cattle, grain, and flour from North America continued to flow into the British, French, Dutch, and Spanish West Indian islands throughout the war, albeit at decreased and sporadic levels, despite Parliamentary sanctions and British Naval patrols. ${ }^{91}$

As a result of greater overseas demand, inflated wartime prices, and Franklin's exemption, the number of petitions to export fish out of Massachusetts increased during the

${ }^{88}$ JCC, Vol. 2, 184-185.

89 "Narrative of Vice Admiral Samuel Graves," Boston, December 4, 1774, NDAR, Vol. 1, 4; and Boston Evening Post, December 12, 1774.

${ }^{90}$ For more on the ways the threat to provision imports increased white's fears about slave revolts, see Andrew Jackson O'Shaughnessy, An Empire Divided: The American Revolution and the British Caribbean (Philadelphia: University of Pennsylvania Press, 2000), 92-100, 137-143. Fears of food shortages and slave rebellion led Jamaican and Barbadian whites to join with North Americans in protesting the Stamp Act in 1765, and such anxieties even compelled them to briefly protest against the King's decision to wage war against the colonies in 1775. Ibid., 92-96, 141. For more on the Revolution's adverse impact on the West Indian economy, see Carrington, The British West Indies During the American Revolution; and Sheridan, "The Crisis of Slave Subsistence in the British West Indies during and after the American Revolution."

${ }_{91}$ Albion and Pope estimate that "four vessels out of five reached their ports safely throughout the hostilities." Albion and Pope, Sea Lanes In Wartime, 35. 
initial years of the war. Prior to Franklin's indulgence, there were only six petitions to the Massachusetts Provincial Congress for permission to export fish, five of which were approved. ${ }^{92}$ After the exemption, up to France's formal alliance with America in 1778 (which eliminated the need for many petitions) there were eighteen such appeals. ${ }^{93}$

Why did the Provincial Congress approve or deny the petitions? Local, regional, and “American” identities helped some merchants secure permission to export fish out of the country. Joseph Lee of Marblehead, Nathaniel Tracey of Newburyport, John Stevens, Jr., of Gloucester, Captain George Dodge of Salem, and Prince Gorham of Barnstable (via Chatham) were all affiliated with the Massachusetts fishing industry, and their petitions were approved. “Messieurs” Pierre la Fitte [Lafitte], Frederick de la Porte, Domblider, and Hurel, on the other hand, were affiliated with the French West Indian plantations and their petitions were denied.

${ }^{92}$ For the other petitions not mentioned above, see JEPCM, 377, 413, 419.

${ }^{93}$ Six appeals were granted, three were denied, and the fate of the remainder is uncertain. For the six petitions that were approved, see the petition of Joseph Lee and Nathaniel Tracey, July 26, 1775, in JHRM, Vol. 51, Part I, 14, 19; the petition of John Stevens, Jr., July 26, 1775, in JHRM, Vol. 51, Part I, 14, 18; the petition of Captain George Dodge, sometime in late July, 1775, in JHRM, Vol. 51, Part I, 15; the petition of Prince Gorham, August 5, 1775, in JHRM, Vol. 51, Part I, 46, 47; the petition of "Viellon and Regnault," December 25, 1776, in JHRM, Vol. 52, Part II, 199; and the petition of Bartelemi Wasanis, April 3, 1776, in JHRM, Vol. 51, Part III, 73-74. For the three petitions whose "Liberty" to export fish was "repealed," see the petition of "Messieurs Pierre la Fitte [Lafitte] and Frederick de la Porte, French gentlemen,” April 1, 1777, in JHRM, Vol. 52, Part II, 289, and in JHRM, Vol. 54, 46; the petition of "Messieurs Domblider and Hurel," September 17, 1778, in JHRM, Vol. 54, 43, 46; and the petition of Isaac Smith, April 1, 1777, in JHRM, Vol. 54, 44, 46. For the remaining nine petitions, see JHRM, 1775, Vol. 51, Part I, 167; JHRM, 1775-1776, Vol. 51, Part III, 118, 122; JHRM, Vol. 52, Part I, 101; and JHRM, Vol. 52, Part II, 115, 199, 286, 288. 
Yet a few foreign merchants applied for and received permission to export fish. "Viellon and Regnault," two merchants from "St. Nicholas Mole, in the West-Indies," were allowed to sell "a large cargo of merchandize" and purchase "a quantity of dry and pickled fish, and lumber." ${ }^{94}$ Their petition differed from the others because they had asked for permission to ship fish out of the country in exchange for West Indian "merchandize."95 Yet Viellon and Regnault were still foreign merchants applying to, and receiving favor from, American politicians. It was likely that certain merchants had built up networks of trust prior to the Revolution, and were then the ones rewarded with government dispensations during the war. ${ }^{96}$

The cod trade thus continued despite Parliamentary prohibitions and the British Naval blockade. The trade was circumscribed, involving only those markets willing and able to return military stores. Merchants were further required by the Revolutionary government to seek permission to trade. And, for the most part, only refuse grade dried cod was allowed to leave the continent in civilian vessels. Some merchants, however, were able to trade at inflated prices and those in government positions were given extra funds to compensate them for their efforts. In this manner, the world of commerce was bent to the way of war.

${ }^{94}$ JHRM, Vol. 52, Part II, 199.

${ }^{95}$ By July 1775, the Continental Congress had "invited the French, Dutch, \& Danes inhabiting the West Indies to send the Produce of their Islands in their own Bottoms" to the North American colonies. In exchange, the foreign West Indian merchants were guaranteed "they should have the produce of this Country in Barter." "Copy of a Letter to Mr. [Philip] Stephens, Secretary of the Admiralty, Dated at Philadelphia, July 30, 1775,” NDAR, Vol. 1, 1013.

${ }_{96}$ More work needs to be done on the identities of the merchants, foreign and domestic, involved in supplying the American armed forces during the Revolutionary War. 


\subsection{PROVISIONING THE ARMED FORCES}

The overall cost of the conflict remained a concern throughout the Revolution, and the leadership constantly sought ways to reduce expenditures. ${ }^{97}$ As a result, the lifeblood of New England's colonial commerce itself was converted to military use during the American Revolution. Political and military leaders relied on dried, salted codfish in order to reduce expenses associated with prosecuting the war.

Fish had been typically less expensive than other primary sources of protein, such as pork and beef, before the war. In 1762, Salem merchants paid £3.0.0 and £2.4.0 per barrel for South Carolina pork and beef, respectively. ${ }^{98}$ At the same time, New England merchantable and refuse grade dried cod sold at $£ 0.13 .1$ and £0.7.2 per quintal. $^{99}$ Given that a quintal equaled 112 lbs., and assuming a barrel of pork or beef equaled a British hundredweight, also 112 lbs., then pork sold at 6.4 pence per pound; beef sold at 4.7 pence per pound; merchantable dried cod sold at 1.4 pence per pound; and refuse dried cod sold at 0.77 pence per pound. Pork was thus 4.6 times more expensive than merchantable dried cod and 8.3 times more costly than refuse dried cod, while the price of beef was 3.4 times higher than merchantable dried cod and 6.1 times higher than refuse dried cod. Dried cod had supplied free and slave workers with inexpensive amounts of protein for centuries, and it cheaply fueled fighting men during the Revolutionary War.

The Continental Army had more mouths to feed than even the largest urban centers in British North America between 1775-1783. Philadelphia was the largest city, with a population

\footnotetext{
${ }^{97}$ For more on these concerns, see Carp, To Starve the Army at Pleasure; and Ferguson, The Power of the Purse.

${ }^{98}$ Schooner Esther, 1760-68, Box 5, Folder 3, Timothy Orne Shipping Papers, JDPL.

${ }^{99}$ Daniel Vickers, "'A Knowen and Staple Commoditie': Codfish Prices in Essex County, Massachusetts, 16401775," Essex Institute, Historical Collections, Vol. CXXIV, (Salem, MA: Newcomb and Gauss, 1988), 202, Table 1.
} 
of 33,290 in 1775. New York City maintained a population of 21,863 in 1771. Boston supported around 16,000 people in 1775 . Throughout the war, the Army's total manpower on a yearly basis was: 32,625 in 1775; 78,425 in 1776; 51,175 in 1777 ; 39,225 in 1778 ; 36,700 in 1779 ; 33,825 in 1780 ; 25,600 in 1781; and 15,250 in 1782. On average, there were 39,103 men in the Army. Thus, there were typically more people in the Army than there were in the leading city of Philadelphia or the entire colony/state of Georgia. ${ }^{100}$

These fighting men required enormous amounts of food. In 1778, the commissary general for the Army estimated that a force of 81,000 would consume 203,000 barrels of flour each year. ${ }^{101}$ The demand for this flour contributed in part to the Continental Congress' decision in 1777 to form a permanent army, enlist smaller numbers of men for the duration of the war, and thereby preserve the agricultural workforce for sowing and reaping.

But, the fighting men did not live on bread alone. At the start of the war in June, 1775, the Massachusetts Committee of Supplies set down "the allowance for provisions for the soldiers of the Massachusetts army.” "Each soldier” was to receive the following daily rations:

One pound of bread. Half a pound of beef and half a pound of pork; and if pork cannot be had, one pound and a quarter of beef; and one day in seven they shall have one pound and one quarter of salt fish, instead of one day's allowance of meat. One pint of milk, or, if milk cannot be had, one gill of rice. One quart of

\footnotetext{
${ }^{100}$ For Philadelphia, see Billy G. Smith, The "Lower Sort”: Philadelphia's Laboring People, 1750-1800 (Ithaca, N.Y.: Cornell University Press, 1990), Table B.1, 206. For New York City, see Edward Countryman, A People In Revolution: The American Revolution and Political Society in New York, 1760-1790 (Baltimore: Johns Hopkins University Press, 1981), 331, footnote \#52. For Boston, see Gary B. Nash, The Urban Crucible: Social Change, Political Consciousness, and the Origins of the American Revolution (Cambridge: Harvard University Press, 1979), Figure 1, 409; and Carl Bridenbaugh, Cities In Revolt: Urban Life In America, 1743-1776 (New York: Alfred A. Knopf, 1955), 5. For the Army, see Buel, Jr., In Irons, Table 2.1, 49. The Army figures include all of the men raised for service "from North Carolina to present-day Maine." Georgia maintained a population of 15,000 in 1775. Robert V. Wells, The Population of the British Colonies in America before 1776: A Survey of Census Data (Princeton, New Jersey: Princeton University Press, 1975), Table VII-5, 284.

${ }^{101}$ Buel, Jr., In Irons, 27.
} 
good spruce or malt beer. One gill of peas or beans, or other sauce equivalent. Six ounces of good butter per week." 102

At the same time, the daily rations for troops from Connecticut included: $3 / 4$ of a pound of pork or one pound of beef; one pound of bread or flour; three pints of beer "or Spruce Sufficient;” and one pint of milk. Salt fish was to be substituted for the daily meat ration three times a week, and each man was to receive $1 / 2$ pint of rice or one pint of meal, six ounces of butter, and three pints of peas or beans each week. ${ }^{103}$ "The Ration of Provisions allowed by the Continental Congress unto each Soldier” included the following: either one pound of fresh beef, or $3 / 4$ of a pound of pork, or one pound of Salt Fish per day; one pound of bread or flour per day; three pints of Peas, or Beans, or "Vegetables equivalent," per week; one pint of milk per day "when to be had;" 1/2 pint of rice, or one pint of “Indian meal," per week; and one quart of “Spruce Beer," or nine gallons of molasses "per Company of 100 Men," per day. On Monday and Wednesday mornings, soldiers were to get a "ration" of salt and fresh meat, and two rations of bread. Every Friday was deemed a fish day, and soldiers were to get a ration of "salt Fish."104 Clearly, none of these soldiers were meant to live on dried cod, but Massachusetts, Connecticut, and the Continental Congress did recognize the added value in supplementing men's' diets with inexpensive fish.

The Continental Navy did not have nearly as many mouths to feed as the Army. Throughout the war, the Navy's manpower per year was: 550 in 1775; 1,910 in 1776; 4,023 in 1777 ; 2,840 in $1778 ; 2,428$ in $1779 ; 1,726$ in $1780 ; 1,724$ in 1781 ; and 640 in $1782 .^{105}$ On average, 1,980 men served in the Navy in any given year. And fish played an important role in

\footnotetext{
102 JEPCM, 317-318.

${ }^{103}$ PGW, Vol. 1, 233, footnote \#22.

${ }^{104}$ General Orders, Head Quarters, Cambridge, August 8, 1775, PGW, Vol. 1, 269; and JCC, Vol. 3 , 322.

105 Buel, Jr., In Irons, 293, footnote \#60.
} 
feeding them. The Continental Navy was formally established on October 30, 1775, when the Continental Congress appointed seven men to a Naval Committee. Four of the Committee members were New Englanders, including John Adams, who was familiar with the commercial fishing industry as he lived in the port community of Quincy, Massachusetts. ${ }^{106}$ He also represented fish merchants in legal cases, and became knowledgeable about the industry in order better to defend his clients. ${ }^{107}$ In his proud words, "My Practice as a Barrister in the Counties of Essex, Plymouth and Barnstable had introduced me to more Knowledge both of the Cod and whale fisheries and of their importance both to the commerce and Naval Power of this Country than any other Man possessed." ${ }^{108}$ Hyperbole aside, Adams' intimate knowledge and appreciation of the fishing industry, combined with a concern for the Continental Congress' expense account, led him to insert the following clause in the very first "Rules for the Regulation of the Navy of the United Colonies” on November 28, 1775:

${ }^{106}$ John Adams represented Massachusetts; Stephen Hopkins, Rhode Island; John Langdon, New Hampshire; and Silas Deane, Connecticut. The three non-New England committee members were: Christopher Gadsden, South Carolina; Joseph Hewes, North Carolina; and Richard Henry Lee, Virginia. O'Connor, Origins of the American Navy, 15; and Morison, John Paul Jones, 36. Adams later reflected that his time "in this naval Committee" represented "the pleasantest part of my Labors for the four Years I spent in Congress." L.H. Butterfield, ed., The Adams Papers: Diary \& Autobiography of John Adams, Volume III, Diary 1782-1804, and Autobiography through 1776 (New York: Atheneum, 1964), 350. Between 1775 and 1776, the Naval Committee was expanded to a thirteen member Marine Committee. By 1777, two Navy Boards, one in Philadelphia and another in Boston, and fourteen prize agents were established to assist the Marine Committee in naval matters. In 1779, a five member Board of Admiralty replaced the Marine Committee in Congress. The naval theater continually expanded as more European powers got involved in the war, and the Board of Admiralty proved an inefficient administrative tool for dealing with the changing realities of naval conflict. As a result, by 1781 Congress gave what amounted to full authority over the American naval theater to Robert Morris. Ben Franklin controlled the European theater of naval operations. William Bingham orchestrated naval action in the Caribbean. And Oliver Pollock directed naval policy in the Gulf of Mexico and on the Mississippi River. Mevers, "Naval Policy of the Continental Congress,” 3-11; Morris' introduction, The American Navies of the Revolutionary War, 15-16; and Charles Oscar Paullin, The Navy of the American Revolution: Its Administration, its Policy, and its Achievements (Cleveland: The Burrows Brothers Company, 1906).

${ }^{107}$ See, for example, L.H. Butterfield, ed., The Adams Papers: Diary \& Autobiography of John Adams, Volume I, Diary 1755-1770 (New York: Atheneum, 1964), 154-157.

${ }_{108}$ John Adams Autobiography, Part 2, "Travels, and Negotiations," 1777-1778, Sheet 1 of 37, in the Adams Family Papers, MHS. 
All ships furnished with fishing tackle, being in such places where fish is to be had, the Captain is to employ some of the company in fishing; the fish to be distributed daily to such persons as are sick or upon recovery, provided the surgeon recommend it, and the surplus, by turns amongst the messes of the officers and seamen, without favor or partiality and gratis, without any deduction of their allowance of provisions on that account. ${ }^{109}$

In addition to moral prohibitions forbidding naval seamen "to swear, curse, or blaspheme the name of God," and formal recognition of "the cat of nine tails" as a disciplinary tool, the fishing clause and other regulations were made to apply to "Commanders of all ships and vessels belonging to the thirteen United Colonies,” which retroactively included the armed schooners fitted out at Beverly and leased to the Continental Congress through Washington. ${ }^{110}$ Those serving on board former fishing vessels, and anyone else the Naval Regulations applied to, were encouraged to catch their food and thereby save the Continental Congress expense.

Fish was also used to feed coast guard units. On June 28, 1775, the Massachusetts Provincial Congress resolved to establish permanent "companies on the sea coast." Thirty-five companies, consisting of fifty men each, were raised and stationed in port communities from Plymouth county in southern Massachusetts to Cumberland county in what is today Maine. ${ }^{111}$ Then, between December 28 and January 4, 1775/1776, the Provincial Congress debated and resolved to expand the number of "Forces to guard the Sea Coast." A total of 2,650 men were recruited to guard coastal communities between Martha's Vineyard and Falmouth (now Portland, Maine) for the period of one year. ${ }^{112}$ Although the port communities themselves were

${ }^{109}$ JCC, Vol. 3, 380; and NDAR, Vol. 2, 1176, 1179. In addition to fish, naval seamen were given daily rations of rum, bread, beef, pork, peas, rice, butter, cheese, turnips, potatoes, and onions. For Adams' formative role in writing the Naval Regulations, see Frederick H. Hayes, "John Adams and American Sea Power," The American Neptune, XXV (1965), 36; and Butterfield, ed., The Adams Papers, Vol. III, 346, footnote \#2.

${ }^{110} \mathrm{~A}$ full discussion of these schooners can be found in subsequent sections of this chapter.

111 JEPCM, 412-413.

${ }^{112}$ JHRM, Vol. 51, Part II, 87-91, 96, 112. On April 9, 1776, the Provincial Congress raised another eight seacoast defense companies, 50-75 men each, 400-600 men total, to guard Boston. JHRM, Vol. 51, Part III, 100 
responsible for recruiting the men, the Provincial Congress established the organizational structure for these units. The Congress issued orders for these men; established commissary agents in certain regions to better provide for the men; and created a pay scale and a military hierarchy for what was, in effect, the first coast guard (albeit at the colony/state level) in American history. The Congress assigned the following daily rations to the coast guard units: one pound of wheat bread, or 11/4 pounds of "other Bread;" one pound of pork, or 11/4 pounds of beef; "and where Salt Fish can be had, they shall be allowed one Pound of Fish one Day in seven, instead of one Day's Allowance of Meat.”113 In this way, the Provincial Congress hoped to mitigate the costs associated with establishing a coast guard.

Fish also played an important role in supplying the dietary needs of privateers during the Revolution. In 1779, Richard and Knott Pedrick, Marblehead fish merchants, jointly owned, outfitted, and manned the brig General Glover. ${ }^{114}$ The vessel was provisioned in part with 50 "fresh fish." In addition, she was equipped with one cod line valued at £2.8.0. According to the "Bill of Fair" for the Salem privateer ship Porus in 1781, men ate beef three days a week; pork two days; and "salt fish" every Saturday. ${ }^{115}$ The cod line, like the Naval Regulation and the dietary supplements, was meant as a cost-saving measure. Like fish in general, it helped improve the bottom-line of fighting the war and enabled merchants and political leaders to allocate funds elsewhere.

${ }^{113}$ JHRM, Vol. 51, Part II, 88. The men were also given "one Shilling and eight Pence per Week to purchase Milk, Butter, Pease, or other Sauce, Soap, and Vinegar.”

${ }_{114}$ Richard Pedrick Account Book, 1767-1784, MDHS. John Glover had been promoted to Brigadier General in 1777. Billias, General John Glover and His Marblehead Mariners, 131.

${ }^{115}$ Logbook of the Porus, 1781, JDPL. 


\subsection{ARMING FISHING SCHOONERS}

In addition to transforming trade routes into supply lines and turning a saleable commodity into military provisions, fishing vessels themselves were converted into warships during the Revolution. During the first three years of war, 1775-1777, the U.S. Navy only had four frigates, which usually carried twenty-four to forty-four guns on a single gun deck, in operation. ${ }^{116}$ Most of the vessels engaged in combat at sea with the British during this period were much smaller in design, and among these fishing schooners featured prominently as both privateers and naval warships. ${ }^{117}$ Fish merchants did not transform their property from one kind of vessel to another solely out of ideological commitment, but they did demonstrate another way in which their industry was crucial to the war effort.

There is a long Atlantic tradition in which various regions and peoples have used fishing vessels for military/defense purposes during periods of war. As early as the fifteenth century, indigenous peoples on the West Coast of Africa carved vessels from the trunks of tropical trees and used them along the coastline and inland waterways for a variety of commercial purposes, including fishing. They also used these vessels for attempting to ward-off well-armed Portuguese slave ships. ${ }^{118}$ Similarly, Native Americans all along the Atlantic seaboard in North America constructed dugout canoes from fallen trees along with kayaks and umiaks from the

\footnotetext{
${ }^{116}$ See, Richard B. Morris’ introduction, The American Navies of the Revolutionary War (New York: G.P. Putnam's Sons, 1974), 17. For more on late-eighteenth-century frigates, see Fowler, Rebels Under Sail, 190-223; and Albion and Pope, Sea Lanes In Wartime, 22. Fowler places the lower limit of guns typically found on frigates at twenty-four, while Albion and Pope place the upper limit at forty-four. According to Fowler, "only nineteen" frigates actually made it into the U.S. Naval service over the course of the entire war. Ibid., 190.

${ }^{117}$ Between 1776 and 1783, the British Navy captured and sent to the naval base at Halifax, Nova Scotia 178 colonial vessels. Eighty-three of these vessels, $47 \%$, were schooners. Sloops were the next most captured vessel type. Fifty-three sloops, 30\% of the total, were captured during the war. Albion and Pope, Sea Lanes In Wartime, 41.

${ }^{118}$ John Thornton, Africa and Africans in the Making of the Atlantic World, 1400-1800, $2^{\text {nd }}$ ed., (New York: Cambridge University Press, 1998), 37.
} 
skins of walrus and seals. These vessels were utilized for a mixture of traveling, trading, fishing, hunting, and fighting-off European invaders. ${ }^{119}$ The Spanish Armada, which remains one of the most famous flotillas in all of recorded history, included Basque, Portuguese, and Spanish fishing vessels. ${ }^{120}$ One of the reasons England's Lord Baltimore moved from Newfoundland in the first half of the seventeenth century was the fact that he lost money by having to employ his fishing servants and vessels in war with the French instead of fishing and freighting cod to European markets. ${ }^{121}$ England's Rump Parliament relied upon "shallops and ketches,” vessels primarily used to catch fish, in addition to ships of the line, to defend its newfound sovereignty from Royalists at home and abroad. ${ }^{122}$ Dutch fishing vessels performed military service and many were lost during the first Anglo-Dutch war. ${ }^{123}$ Fishing shallops and schooners were also very valuable to the British Naval squadron patrolling Newfoundland waters during the 1760s and 70s for illicit traders, as they enabled Naval officers to get in and out of smuggler's coves. ${ }^{124}$ The British Navy likewise found schooners valuable in their efforts to curtail smuggling around Boston on the eve of the Revolutionary War, and some had been previously used as commercial

${ }^{119}$ Benjamin W. Labaree, William M. Fowler, Edward W. Sloan, John B. Hattendorf, Jeffrey J. Safford, and Andrew W. German, America and the Sea: A Maritime History (Mystic, Conn.: Mystic Seaport Museum Publications, 1998), 23-28; and Denys Delâge, Bitter Feast: Amerindians and Europeans in Northeastern North America, 1600-64, translated by Jane Brierley, (Vancouver: UBC Press, 1993), 51. Also, see Samuel E. Morison, The European Discovery of America: The Northern Voyages, A.D. 500-1600 (New York: Oxford University Press, 1971), frontispiece, "Frobisher’s fight with Eskimos at Frobisher Bay."

${ }^{120}$ Michael Barkham, "Spanish Ships and Shipping,” in M.J. Rodríguez-Salgedo, ed., Armada, 1588-1988 (London: Penguin Books in association with the National Maritime Museum, 1988), 151-163.

${ }^{121}$ Peter E. Pope, Fish Into Wine: The Newfoundland Plantation in the Seventeenth Century (Chapel Hill: The University of North Carolina Press, 2004), 126.

${ }^{122}$ Bernard Capp, Cromwell's Navy: The Fleet and the English Revolution, 1648-1660 (Oxford: Clarendon Press, 1989), 4.

${ }^{123}$ Jonathan I. Israel, The Dutch Republic: Its Rise, Greatness, and Fall, 1477-1806, $4^{\text {th }}$ ed., (Oxford, England: Oxford University Press, 1998), 715-717.

${ }^{124}$ See, for example, NA ADM 1/470/60. Commodore John Byron purchased “a Marblehead Schooner” for the Navy's use in late 1770. Also, for evidence that Commodore Hugh Palliser confiscated French fishing vessels in 1765 and converted them to British warships, see NA SP 78/269/289-291. 
fishing vessels. ${ }^{125}$ Virtually all maritime peoples around the Atlantic world relied on fishing fleets for more than catching fish. ${ }^{126}$ Thus, the decision to begin arming fishing vessels during the Revolutionary War cannot be seen as an innovation or a distinctly "American” way of war. It was in fact an old Atlantic tradition.

Colonial Americans desperately needed to establish a naval force in order to win the Revolution. By June 30, 1775, there were 29 British warships stationed off the coast of North America between Florida and Nova Scotia. These warships carried a total of 584 guns and 3,915 men. ${ }^{127}$ Vice Admiral Samuel Graves maintained eight warships under his command for patrolling the New England coastline alone. ${ }^{128}$ By October 9, 1775, thirty-five British Naval vessels, including twelve ships of the line, patrolled the coastline of North America. Fifteen of these warships, and no less than seven of the twelve rated warships, were positioned in New England waters at this time. ${ }^{129}$ These vessels could serve a variety of purposes: engage colonial positions on land, transport and evacuate troops, cut-off colonial exports, and prevent any supplies from entering the colonies from overseas. For their part, the colonists had no navy at the beginning of 1775. A fierce debate emerged suddenly on the subject of arming vessels for war.

${ }^{125}$ The H.M.S. Gaspee that was burned on the coast of Rhode Island while pursuing smugglers in Narragansett Bay in 1772 was a schooner. See, "Diary of Dr. Ezra Stiles," Newport, May 4, 1775, NDAR, Vol. 1, 279. Neil Stout has referred to the schooner's patrolling the North American coast-line for the British Navy as "the original coast guard cutters.” Neil R. Stout, The Royal Navy In America, 1760-1775: A Study of Enforcement of British Colonial Policy in the Era of the American Revolution (Annapolis, Maryland: The United States Naval Institute, 1973), 59.

${ }^{126}$ More work needs to be done on the historic relationship between fishing vessels and war. In particular, it is not known whether fishing vessels were duly factored into a region's naval power, by its own peoples or its enemies, or if these vessels were merely stop-gap measures pursued by desperate peoples in periods of crisis.

127 "Vice Admiral Samuel Graves to General Thomas Gage,” Boston, June 30, 1775, NDAR, Vol. 1, 785.

128 "Vice Admiral Samuel Graves to General Thomas Gage," Boston, July 5, 1775, NDAR, Vol. 1, 819-820.

${ }^{129}$ NA CO 5/122/35. 
Fitting-out vessels for war occupied the attention of political leaders in the colonies from the very beginning of the war in $1775 .^{130}$ The earliest recorded argument in favor of "some Armed Vessels" was made prior to June 4, 1775. "S.L." tried to convince the Massachusetts Provincial Congress that these "Armed Vessels" were necessary "to ward off the distressing Piratical blows that without doubt will be struck by [Vice] Admiral Samuel Graves’ small Men [of] war \& Tenders.” The British naval blockade of the colonial coastline posed a direct threat to “our inward bound Provisions, Molasses, \& Salt Vessels \&c.”131 Around this time, Christopher Gadsden, a former purser in the British Navy and a member of the Continental Congress from South Carolina, met John Adams, then acting as Massachusetts’ representative, at the Congress

\footnotetext{
${ }^{130}$ There is no scholarly consensus on the genesis of the American Navy. Fowler credits Massachusetts with the origins of organized naval resistance to British authority. Fowler, Rebels Under Sail, 25-43. Miller maintains Rhode Island drew up "the first formal movement in behalf of a Continental Navy" on August 26, 1775. Miller, Sea of Glory, 41. Also, see O'Connor, Origins of the American Navy, 15; and Frank C. Mevers, "Naval Policy of the Continental Congress," in Maritime Dimensions of the American Revolution, 3. O'Connor, Fowler, Miller, Billias, Clark, Morison, and Knox state in no uncertain terms that Washington developed the idea of arming commercial vessels for war. O'Connor, Origins of the American Navy, 14; Fowler, Rebels Under Sail, 29; Miller, Sea of Glory, 60-61; Billias, General John Glover and His Marblehead Mariners, 73; Clark, George Washington's Navy, 3; Morison, John Paul Jones, 35; and Knox, The Naval Genius of George Washington, 8. Morison goes so far as to refer to Washington as the "“Founder' of the United States Navy." Clark unequivocally states: "General Washington provided the idea." Hearn credits Washington and John Glover, a Marblehead fish merchant, with the idea. Hearn, George Washington's Schooners, 10. For his part, Vincent Dowdell, Jr., claims Marblehead merchants developed the idea. Vincent Dowdell, Jr., "The Birth of the American Navy,” U.S. Naval Institute Proceedings, LXXXI (November, 1955), 1251-1257. O’Connor, Mevers, and Miller acknowledge the commander-in-chief's role in fitting out vessels for war at Beverly, Massachusetts in 1775. However, they lean toward separating Washington's schooners from the American Navy. Mevers' dismissive view is typical on this score: "It is doubtful that Washington intended the squadron to do any more than harass, and it is probably that by this direct action he was demonstrating to Congress his belief in the possibilities of action at sea through a larger maritime force.” Mevers, “Naval Policy of the Continental Congress,” 3. Mevers credits Congress' Naval Committee and Marine Committee, established between 1775 and 1776, with the formation of the first American Navy.

It is clear that as late as August 11, 1775, Washington advised the Massachusetts Provincial Congress/General Court against arming vessels. In a letter to the Court, Washington discussed various issues, including dealing with a traitor and a planned invasion of Nova Scotia. Then, turning to the subject of "furnishing [i.e. outfitting] Vessels of Force,” Washington wrote, "You Gentlemen will Anticipate me in pointing out our Weakness \& the Enemy's Strength at Sea." His "Reasons against" arming vessels included his fear that smaller ships would "fall an easy Prey either to the Men of War on that Station or Some who would be Detached from Boston," and his concern regarding "our Situation as to Ammunition." "George Washington to a Committee of the General Court of Massachusetts Bay," Camp at Cambridge, August 11, 1775, NDAR, Vol. 1, 1114-1115. I am suggesting that the initial impetus behind arming vessels came from various quarters, not solely from Washington. The commander-in-chief's willingness to part with manpower and gunpowder from the Army came only in late August.

131 "S.L. to Joseph Warren, President of the Massachusetts Provincial Congress, Watertown,” June 4, 1775, NDAR, Vol. 1, 607-609.
} 
in Philadelphia. As Adams reported in a letter written to Elbridge Gerry on June 7, 1775, Gadsden was “confident that We may get a Fleet of our own, at a cheap Rate.” Gadsden believed that smaller commercial vessels, such as fishing vessels, could be converted into warships, and that the expense of building an entirely new naval fleet could be avoided. Such a “cheap” navy could “easily take their Sloops, schooners and Cutters [smaller vessels], on board of whom are all their best Seamen, and with these We can easily take their large Ships, on board of whom are all their impressed and discontented Men.”132 Gadsden believed that such pressed men would not put up much of a fight against their own countrymen.

When Adams transmitted Gadsden's thoughts to Gerry, the Massachusetts Provincial Congress went back and forth over the issue of arming vessels for war. On June 7, the Congress established a sub-committee of eight merchants "to consider the expediency of establishing a number of small armed Vessels to cruise on our sea-coasts for the protection of our trade and the annoyance of our enemies.” ${ }^{33}$ Provincial Congressmen debated the issue until shortly after the Battle of Bunker Hill, in which British forces were able to move troops at will and bombard colonial positions from the sea. On June 20, 1775, the Provincial Congress resolved "that a number of armed Vessels, not less than six, to mount from eight to fourteen carriage guns, and a proportionable number of swivels, \&c. \&c. be with all possible dispatch provided, fixed, and properly manned, to cruise as the Committee of Safety, or any other person or persons who shall be appointed by this Congress for that purpose, shall from time to time order and direct, for the protection of our trade and sea-coasts against the depredations and piracies of our enemies, and

\footnotetext{
132 “John Adams to Elbridge Gerry, Marblehead,” Philadelphia, June 7, 1775, NDAR, Vol. 1, 628-629.

133 “Journal of the Provincial Congress of Massachusetts,” Watertown, June 7, 1775, NDAR, Vol. 1, 621-622.
} 
for their annoyance, capture, or destruction." The matter was "ordered to subside for the present." ${ }^{134}$ This program of arming vessels would resume in Massachusetts later in August.

In the interim, other plans for arming vessels emerged. On June 27, 1775, Nicholas Cooke, the deputy Governor of Rhode Island, wrote to the Massachusetts Committee of Safety to suggest adding "a few Vessels properly armed and manned along the Coast in different parts" in order to protect "our own trade" and to capture "many of the provision Vessels that the Men of War take this way and send round to Boston; many of those Vessels are sent Round [Cape Cod] with but five or six hands in each and With nothing more that a Small arm a-piece to defend them." Cooke further observed that "as the Enemy think we have no force that dare put out of our harbors some of their Store Ships come Without Convoy and there is a possibility that we might pick up one of them if we had a Vessel or two to Cruise in their way.”"135 Josiah Quincy wrote to John Adams on July 11, 1775, and suggested "Row Gallies...navigated with many Men...armed with Swivels, and one large battering Cannon in the Bow of each" to "convoy 10 or a Dozen provision Vessels from Harbor to Harbor in the summer Season.” He also asked "why might not a Number of Vessels of War be fitted out, \& judiciously stationed, so as to intercept \& prevent any Supplies going to our Enemies; and consequently, unless they can make an Impression Inland they must leave the Country or starve.”136 All of these plans for arming vessels were forwarded to the Massachusetts Provincial Congress or to John Adams, Massachusetts' delegate at the Continental Congress, who then sent them on to the political leaders in his home colony.

134 “Journal of the Provincial Congress of Massachusetts,” Watertown, June 20, 1775, NDAR, Vol. 1, 724. Emphasis my own. O'Connor contends “this proposal was never implemented.” O'Connor, Origins of the American Navy, 14. But, he has not considered the conversion of fishing vessels.

135 "Nicholas Cooke, Deputy Governor of Rhode Island, to the Massachusetts Committee of Safety," Providence, June 27, 1775, NDAR, Vol. 1, 762.

136 “Josiah Quincy to John Adams, A Massachusetts Delegate to the Continental Congress,” Braintree, July 11, 1775, NDAR, Vol. 1, 859. 
The initial colonial naval strategy, then, was worked out between June and July, 1775, and transmitted to the seat of war in Massachusetts. The plan at this time involved arming and manning smaller commercial vessels, usually under 100 tons, which could be fitted out quickly and at low cost in order to capture successively larger warships, protect colonial shipping, and cut British military supply lines. Such a scheme should not be conflated, however, with the eighteenth-century way of war known as guerre de course, or cruiser warfare, in which merchant vessels were targeted in hit-and-run tactics in order to bring economic and political pressure to bear on a government through increased maritime insurance rates, price inflation, and shipping losses. ${ }^{137}$ The colonist's strategy involved these goals, to be sure, but they also hoped to reduce Britain's sea power. By cutting British supply lines and capturing increasingly larger warships it was hoped that British forces in Boston would run out of food and evacuate the port city. Colonists also believed they could carve a path through the British naval blockade in order to allow trade to continue unmolested.

On July 18, 1775, the Continental Congress officially sanctioned the conversion of commercial shipping into armed vessels. The members resolved "that each colony, at their own expense, make such provision by armed vessels or otherwise, as their respective assemblies, conventions, or committees of safety shall judge expedient and suitable to their circumstances and situation for the protection of their harbors and navigation on their sea coasts, against all

${ }^{137}$ Guerre de course is customarily equated with privateering. See, Gardiner, ed., Navies and the American Revolution, 1775-1783, 66-69; Fowler, Rebels Under Sail, 22-23; and Albion and Pope, Sea Lanes In Wartime, 2526. Mevers argues that the first American naval strategy "relied heavily on privateers to harass British vessels," rather than to capture or destroy British seapower. Mevers, "Naval Policy of the Continental Congress," 5. For a discussion of guerre de escadre, using large warships to fight fleet engagements against enemy fleets, see Kenneth J. Hagan, This People's Navy: The Making of American Sea Power (New York: Free Press, 1991), xi. Hagan counters Alfred T. Mahan's argument that American sea power was built on a strategy of guerre de escadre. For Hagan, American sea power has been predicated upon guerre de course, prosecuted first in the Revolutionary War. I agree with Hagan that smaller vessels have played an important, even formative, role in the history of American sea power. We part ways in defining the naval strategy Americans pursued in the Revolution as guerre de course. Commerce-raiding was only part of the strategy. 
unlawful invasions, attacks, and depredations, from cutters and ships of war.” ${ }^{238}$ This resolution paved the way for all future endeavors along these lines.

Over the course of July and much of August, the Massachusetts Provincial Congress searched for vessels suitable enough to be "fixed, and properly manned" for war. ${ }^{139}$ John Glover, a merchant from Marblehead involved in the fishing industry and the Colonel of the port town's regiment, had been assigned to guard Washington's headquarters and the Provincial Congress at Watertown early in $1775 .{ }^{140}$ He must have been involved in this search, although no official document has survived linking Glover to the assignment. The Provincial Congress was certainly aware of Glover and his position of authority in the foremost commercial fishing port in New England, and they had relied on him in the past. ${ }^{141}$ At some point in August, Glover succeeded in assembling five of the six vessels the Provincial Congress had resolved back in June to arm. The vessels were all fishing schooners; they all belonged to fish merchants in Marblehead; and they were all converted into warships in Beverly's harbor. The schooners were the Hannah, Franklin, Hancock, Lee, and Warren. ${ }^{142}$ Then, around August 24, Glover

${ }^{138}$ JCC, Vol. 2, 189.

139 “Journal of the Provincial Congress of Massachusetts,” Watertown, June 20, 1775, NDAR, Vol. 1, 724.

${ }^{140}$ For more on Glover, see Billias, General John Glover and His Marblehead Mariners. Also, see the biographical information compiled in Smith, ed., The Journals of Ashley Bowen (1728-1813), Vol. 2, 657.

${ }^{141}$ See, for example, "Minutes of the Massachusetts Committee of Safety," Cambridge, April 27, 1775, NDAR, Vol. 1, 229. The Committee, which was affiliated with the Provincial Congress, ordered "That Colonel John Glover" use his authority in Marblehead "for the prevention of Intelligence" leaking to the British patrol vessels in the port's harbor.

${ }^{142}$ The Hannah is described in subsequent sections. The Franklin, Hancock, Lee, and Warren were owned by, respectively, Archibald Selman, Thomas Grant, Thomas Stevens, and John Twisden, all Marblehead fish merchants. The Hancock was described during the Revolution as "Seventy two Tuns; Taken up for the Service of the united Colonies of America...worth Three Hundred Thirty one pounds Six Shillings \& Eight pence." "Appraisal of the Speedwell [renamed Hancock]," Beverly, October 10, 1775, NDAR, Vol. 2, 387. At the same time, the Franklin was described as "Sixty Tuns; Taken up for the Service of the united Colonies of America....worth three Hundred pounds three Shillings and Eight pence.” "Appraisal of the Eliza [renamed Franklin],” Beverly, October 10, 1775, in ibid. The Lee was described as "Seventy four Tuns; taken up for the Service of the united Colonies of America...worth three Hundred and fifteen pounds Eight Shillings.” “Appraisal of the Two Brothers [renamed Lee],” Beverly, October 12, 1775, in ibid., 412. The Warren was described as "Sixty four Tuns; taken up for the Service of the united Colonies in America... worth three Hundred \& forty pounds ten Shillings." "Appraisal of the Hawk [renamed Warren]," Beverly, October 12, 1775, in ibid., 412-413. According to the later testimony of a Revolutionary War 
"informed the General [Washington] that there are 5 Vessels at Beverly." The Marblehead Colonel stated that these vessels "were fitted out for another Purpose," presumably the resolve of the Provincial Congress. It was Glover's opinion, however, that they could support Benedict Arnold's planned invasion of Quebec "equally well.” Arnold required transport ships to carry his expeditionary force to the Kennebec River, from which point they would head toward Quebec. "It will be a saving both in Time \& Expense to make Use of these," Glover believed, as the vessels in Beverly were already prepared for war. ${ }^{143}$ Glover probably intended for the armed schooners to serve the Massachusetts Provincial Congress by preying upon vessels carrying military stores and provisions into Boston for the British military until Washington needed those

pensioner, the Franklin and the Hancock "were Fishing Schooners \& had no Bulwarks more than common vessels except Nettings with which they were accustomed to put their clothes in in time of Action.” Cited in Smith and Knight, “In Troubled Waters,” 27. All except the Hannah were re-named, in patriotic fervor, after revolutionary leaders. Washington and his military secretary, Colonel Joseph Reed, mistakenly referred to the Hancock as Lynch in late 1775. For a discussion of these clerical errors, see Billias, General John Glover and His Marblehead Mariners, 216, footnote \#19. Such errors led later historians to make the same mistake. See, Howe, Beverly Privateers In The American Revolution, 325.

It is not known precisely when the Franklin, Hancock, Lee, and Warren were armed and officially taken under Washington's command through Glover. Most scholars assume that the appraisal dates of October 10 and 12 represent the commission dates. See, Billias, General John Glover and His Marblehead Mariners, 78, 82. However, Reed's letter described below in footnote \#143 disputes these October dates. It is probable that the October appraisals were ordered after the vessels had already been secured in Beverly's harbor. Such was the case when the British Navy captured the ship Charming Peggy on July 15, 1775 and sent her into Boston, where the “Two Thousand one hundred \& seventy three Barrels of Flour” could be confiscated for the Army. British General Thomas Gage then hired four local merchants to appraise the flour on August 19, in order to reimburse the flour's owners. The four merchants submitted their appraisal two days later, more than a month after the ship's capture. “General Thomas Gage to Four Boston Merchants,” Boston, August 19, 1775, NDAR, Vol. 1, 1180.

143 “Colonel Joseph Reed to Nathaniel Tracy, Newburyport,” Camp at Cambridge, September 7, 1775, NDAR, Vol. 2, 38. This letter, written by Washington's military secretary, Reed, is crucial in terms of understanding Washington's role in converting fishing vessels into warships. Reed would have had access to any written communication between Glover and Washington, giving him intimate knowledge of what the Marblehead Colonel had observed on a prior occasion. Unfortunately, Reed did not state precisely when Glover informed Washington of the “5 Vessels at Beverly." However, this information must have passed prior to Reed's letter to Tracy on the $7^{\text {th }}$, and most likely occurred around August 24, when the Hannah was leased in Beverly to "the United Colonies of America,” or the Continental Congress, which Washington officially represented. John Glover's Colony Ledger, MDHS, item \#7291/2. At the very latest, the shift in the purpose of these armed fishing schooners occurred on September 2, when Washington issued the sailing orders for the Hannah. See, “George Washington's Instructions to Captain Nicholson Broughton,” September 2, 1775, NDAR, Vol. 1, 1287. In his "Instructions to Nathaniel Tracy" for gathering transport vessels to support Arnold, Washington referred to the invasion as "a secret Expedition.” Washington to Nathaniel Tracy, Cambridge, September 2, 1775, PGW, Vol. 1, 405. 
same schooners to support Arnold's expedition. ${ }^{144}$ After the expedition, the schooners would continue to attack British military supply lines, but they would do so under Washington's command.

On August 24, Glover leased his schooner Hannah, named after his wife, of “78 tons” burden. $^{145}$ The schooner was built in 1765 . Glover purchased her in 1769, and, in typical fashion, the Hannnah and her crew transported fish and lumber to Barbados in the winter months between 1770 and June 1775, probably having worked the offshore banks in the spring, summer, and fall. She returned bearing muscovado sugar and West Indian rum in her hold. ${ }^{146}$ Glover leased the fishing vessel to "the United Colonies of America," or, in other words, the Continental Congress. The Marblehead fish merchant did not lease the schooner to the Massachusetts Provincial Congress, nor did he lease her to Washington. Such a lease underscores the Hannah's role as the first “American” Naval vessel. And she was not given away freely. Glover charged the Continental Congress a rate of “one Dollar p[e]r Ton p[e]r Month,” or "6” shillings, which, “for two Months \& 21 days” amounted to “208 dollars,” or £32.8.0. ${ }^{147}$

\footnotetext{
${ }^{144}$ Eleven transport vessels freighted Arnold's expeditionary force from Newburyport to Gardiner, in the province of Maine. The fleet left on September 19, 1775 and had a sailing time of three days. Abbot and Twohig, eds., The Papers of George Washington, 405. The Hannah prowled the sea in early September, and then, with the other schooners in October.

${ }^{145}$ John Glover's Colony Ledger, MDHS, item \#7291/2. There has been a disagreement about the schooner's size. Fowler describes the Hannah as "a typical New England fishing schooner of about seventy tons." Fowler, Rebels Under Sail, 29. Hearn, Billias, and Clark follow Glover's Colony Ledger in listing her at "seventy-eight tons.” Hearn, George Washington's Schooners, 10; Billias, General John Glover and His Marblehead Mariners, 74; and Clark, George Washington's Navy, 3. Philip C. F. Smith and Russell W. Knight have questioned the use of seventy-eight tons, preferring the much smaller figure of forty-five tons. Philip C. F. Smith and Russell W. Knight, "In Troubled Waters: The Elusive Schooner Hannah,” The American Neptune, Vol. 30, No. 2, (April, 1970), 15, 22, Appendix II, 41. They base their argument for forty-five tons chiefly on the fact that the terms of Glover's lease add up to around £63, rather than his account of £32.8.0. Here, Glover's words pertaining to his own vessel in his own ledger are taken at face value, and his math skills are discounted.

${ }^{146}$ Smith and Knight, "In Troubled Waters,” Appendix II, 41-43.

${ }^{147}$ John Glover's Colony Ledger, MDHS, item \#7291/2. While the amount and the form of payment varied from vessel to vessel, and colony to colony, the rate "per ton per month" was standard. See, for example, "Minutes of the Connecticut Council of Safety," Lebanon, August 3, 1775, NDAR, Vol. 1, 1054; and "Stephen Moylan and Colonel John Glover to George Washington,” Salem, October 9, 1775, NDAR, Vol. 2, 368.
} 
Private Joseph Homan, a Marbleheader who described himself in pension records as "a boat fisherman," was one of the maritime laborers responsible for transforming the schooners into warships. Homan testified that in late 1775, “Col. Glover’s Regiment was stationed as Marine Corps at the Port of Beverly near Salem for the purpose of manning from time to time small vessels of War, fitted out and manned by the American troops, to intercept and capture British Ordinance vessels and transports bound to the British Army in Boston.”148 Ashley Bowen, a maritime denizen of Marblehead and close observer of town events and town members, recorded in his day book on August 24, 1775, that "a company of volunteers from the Camps at Cambridge" marched through town on their way to Beverly "in order for a cruise in Glover’s schooner." ${ }^{\text {149 }}$ Chester G. Hearn has detailed the work done on the Hannah at Beverly:

After tying her up at Glover's Wharf, they cut gunports, two to a side, in her bulwarks and strengthened her planking. For speed, sailmakers increased her usual main, fore, and jib sails by adding topsails and a flying jib. Workmen set a whaleboat amidships and expanded the large cookstove below to serve a larger crew. Glover owned his own cache of arms and provided fours [i.e. four pounders] with carriages, a dozen swivels, and an assortment of gunnery stores. ${ }^{150}$

Glover scrupulously documented the costs he incurred in this conversion process in his ledgerbook. On the same day in August that volunteers arrived in Beverly, he charged £151.4.0 to "the United Colonies of America” for provisioning and manning the Hannah. ${ }^{151}$ Four days later, Glover further billed the Continental Congress £11.9.1 for Ebenezer Foster’s blacksmith work on the schooner. ${ }^{152}$ Foster mounted swivel guns and did other sundry work on the vessel. In short,

\footnotetext{
${ }^{148}$ Pension Records of the American Revolution, “1818 Pensions,” \#1867, the David Library of the American Revolution, Washington Crossing, Pennsylvania.

${ }^{149}$ Smith, ed., The Journals of Ashley Bowen (1728-1813), Vol. 2, 453.

${ }^{150}$ Hearn, George Washington's Schooners, 10. Also, see Clark, George Washington's Navy, 5.

151 John Glover's Colony Ledger, MDHS, item \#7291/2.

${ }^{152}$ Ebenezer Foster’s blacksmith bill, MDHS, item \#5786. According to revolutionary leaders in Connecticut, the materials used to convert a trade ship to a warship in 1775 included "sails, rigging, and furniture, and also all
} 
Glover did not take a financial loss in converting his fishing vessel into a warship. Washington reminded Nicholson Broughton, the Hannah's captain, that it was Congress that had paid his salary, not Glover, in his official sailing orders. ${ }^{153}$ Because of his lease, Glover stood to gain from transforming his peacetime property into a military machine. ${ }^{154}$ Once she had been armed and manned, the Hannah set sail for fame and fortune on September $5 .{ }^{155}$

It might be argued that such former fishing vessels were now privateers. William Falconer, the author of a maritime dictionary in 1769, defined a privateer as a private vessel, fitted out and armed in wartime, "to cruise against and among the enemy, taking, sinking or burning their shipping” in exchange for shares of any captured prizes. ${ }^{156}$ During the Revolution,

proper and necessary ship-stores and provisions, and...the necessary cannon, swivels, small arms, pistols, shot, powder, \&c." "Minutes of the Connecticut Council of Safety,” Lebanon, August 3, 1775, NDAR, Vol. 1, 1053.

${ }^{153}$ Washington took the occasion to remind Captain Nicholson Broughton that, as "a Captain in the Army of the United Colonies of North America,” Broughton personally fell under the commander-in-chief's authority. Moreover, as "the schooner Hannah" had been "fitted out \& equipped with Arms, Ammunition and Provisions at the Continental Expense," Broughton was doubly beholden to Washington. See "George Washington's Instructions to Captain Nicholson Broughton,” September 2, 1775, NDAR, Vol. 1, 1287, emphasis my own. Broughton had been commissioned a captain in Colonel John Glover's regiment on May 19, 1775. Ibid., 1289n.

On October 4, 1775, Washington assigned Stephen Moylan, the Muster Master General, to assist Glover in arming vessels for war. Both men were to report either to Colonel Joseph Reed, Washington's military secretary, or to the commander-in-chief directly. "Colonel Joseph Reed to Colonel John Glover," Head Quarters, Cambridge, October 4, 1775, NDAR, Vol. 2, 289-290; and "Colonel Joseph Reed to Colonel John Glover and Stephen Moylan," Camp at Cambridge, October 4, 1775, in ibid., 290. The two men reported to Washington on October 9, 1775 that the terms of the contracts they had negotiated with vessel-owning merchants included the contentious fact that merchants were required "they shall put their vessels in the same good order \& Condition which they would be obliged to do, were they hired to take in a Cargo for the West Indies or elsewhere.” For their part, Glover and Moylan agreed "that what extra expense may accrue from the nature of their present employment must be a public Charge.” The vessel owners wanted any extra sails, over and above "three sails, Mainsail, foresail, \& jib...sufficient for the Voyages they usually Make," to be "a public Charge." "Stephen Moylan and Colonel John Glover to George Washington," Salem, October 9, 1775, in ibid., 368.

${ }^{154}$ The owners of Washington's schooners do not seem to have received prize shares. One-third of the value of the captured vessel and its cargo, whether it was a commercial or a military prize, went to the crew, while two-thirds went to the Continental Congress in order to repay the cost of outfitting and manning the schooners. Washington did not make the distinction between commercial and military prizes that the Continental Congress later did. “George Washington's Instructions to Captain Nicholson Broughton,” September 2, 1775, NDAR, Vol. 1, 1288.

${ }^{155}$ The Hannah is widely touted as the first armed vessel fitted out in the service of the United States. See, Hearn, George Washington's Schooners, 10; Billias, General John Glover and His Marblehead Mariners, 73; Clark, George Washington's Navy, 3; The American Navies of the Revolutionary War, 22; Smith and Knight, "In Troubled Waters," 29-30; and Knox, The Naval Genius of George Washington, 8. Fowler points to earlier "naval actions" off Cape Cod in Buzzards Bay as the genesis of America's naval history. Fowler, Rebels Under Sail, 26.

${ }^{156}$ William Falconer, A New Universal Dictionary of the Marine (London, 1769), 353. Gardiner defines privateers as "free-enterprise warships, armed, crewed and paid for by merchants who gambled on the dividend of a 
privateers were distinguished from pirates by the fact that the former carried government sanctioned commissions, or letters of marque. ${ }^{157}$ And there is evidence that contemporaries regarded the fleet of armed schooners fitted out at Beverly as a collection of privateers. For example, "Manly, A Favorite New Song in the American Fleet," composed in Salem, Massachusetts in March 1776, referred to the armed schooner Lee, John Manley, Captain, as a "Privateer." 158 Out of exasperation, Washington even went so far as to refer to the men on the schooners as "our rascally privateersmen" in a letter to his secretary Colonel Joseph Reed. ${ }^{159}$ Such evidence, combined with the facts that the fishing schooners remained privately owned and the crews (at least) earned prize shares, has led some naval historians to consider the vessels armed at Beverly to be mere privateers. ${ }^{160}$ Following this line of reasoning, the refitted ships were profit-driven business ventures.

valuable capture.” Gardiner, ed., Navies and the American Revolution, 1775-1783, 66. According to Albion and Pope: "profits were the raison d'être of privateers." Albion and Pope, Sea Lanes In Wartime, 23-24. Beverly merchants printed and made public the following handbill on September 7, 1776: "Now fitting for a Privateer, In the harbor of Beverly, the Brigantine Washington....Any Seaman or Landsman that has an inclination to make their Fortunes in a few months may have an opportunity by applying to John Dyson.” Cited in Howe, Beverly Privateers in the American Revolution, 338, footnote \#2. Boston merchants printed a similar advertisement in the local newspaper on November 13, 1780. "An Invitation to all brave Seamen and Marines, who have an inclination to serve their country and make their Fortunes" was the title of the ad. The Boston merchans shrewdly added that those who signed on for a cruise with the privateer would receive "that excellent Liquor called Grog, which is allowed by all true seamen to be the Liquor of Life.” Boston Gazette, November 13, 1780.

${ }^{157}$ Albion and Pope, Sea Lanes In Wartime, 23. British Naval officers and royal governors did not recognize the authority of colony/state governments or the Continental Congress. Thus, they considered most American warships to be "pirates." See, NDAR, Vol. 1, 607-609, 720-721, 961-962, 970, 1157.

${ }^{158}$ Manly. A favorite new song, in the American fleet. Most humbly addressed to all the jolly tars who are fighting for the rights and liberties of America. By a sailor. (Salem, MA: Printed and sold by E. Russell, upper end of Main-Street, 1776), Early American Imprints, $1^{\text {st }}$ Series, Evans \#43057. Captain Manley’s surname may have been deliberately misspelled in the song-title in order to rally men for war.

159 “George Washington to Colonel Joseph Reed,” Camp at Cambridge, November 20, 1775, NDAR, Vol. 2, 1082.

${ }^{160}$ Gardiner references the "handful of Marblehead fishing schooners, armed with four or six tine 4pdrs and 2 pdrs," in his discussion of "the privateering war," or guerre de course. He argues that these schooners do not represent "the beginnings of a national navy," as "it was conceived with a specific raiding purpose in mind." Gardiner, ed., Navies and the American Revolution, 1775-1783, 66-67. Thus, the schooners were nothing more than commerce raiders. Syrett similarly refers to Washington's schooner fleet as "the American cruiser offensive." Syrett, “Defeat at Sea,” 16. Also, see Howe, Beverly Privateers In The American Revolution. 
Yet the fishing schooners that were armed for war in late 1775 were not mere privateers, for they were leased to the Continental Congress. Indeed, on November 25, three days before the Naval Regulations were formally approved, Congress specifically referred in their debates over the Regulations to "the Captures heretofore made by Vessels fitted out at the Continental Charge," which at this time only pertained to the Beverly fleet. The American political leaders maintained that these captures were "justifiable." ${ }^{\prime 61}$ The prize money these schooners took went not to private investors, as it would have done with privateers, but rather to the government to recoup outfitting costs. Moreover, Washington, whether he developed the idea of arming the vessels or not, played a national role in the process as commander-in-chief of the United Colonies by giving out commissions and issuing sailing orders for the schooners. Additionally, the crews on the armed schooners were also given wages in addition to prize shares. The standard practice for privateers in the late eighteenth century, by contrast, involved giving crews food but not wages. ${ }^{162}$ Thus, there is strong evidence to support the claim that the collection of fishing vessels at Beverly represents the first American Navy.

This is not to say that fishing vessels were only used for what might be considered more dignified, official naval warfare, although the lines were very blurred during the war. Schooners were widely used as privateers. On November 1, 1775, the Massachusetts Provincial Congress passed an "Act Authorizing Privateers and Creating Courts of Admiralty.” The Privateering Act empowered the Provincial Congress "to Commission, with Letters of Marque and reprisal, any person or persons, within this Colony, who shall at his or their own Expense fix out \& equip for the defense of America any Vessel." The Act established a protocol for applying for and receiving letters of marque. This included paying the Provincial Congress's Treasurer a bond of

161 JCC, Vol. 3, 376; NDAR, Vol. 2, 1133; and Butterfield, ed., The Adams Papers, Vol. III, 349.

${ }^{162}$ Albion and Pope, Sea Lanes In Wartime, 23. 
$£ 5,000$. The Act also established laws governing the behavior for privateers. It set up Admiralty courts to adjudicate the legal seizure of prizes at sea, and the Act codified procedures for selling prize ships and their cargo. ${ }^{163}$ Such a system made it possible for fish merchants to apply for letters of marque, convert their fishing schooners, and earn prize money. ${ }^{164}$ In contrast to the Navy armed at Beverly, which had to give two thirds of all prize money to the state, privateers' owners and crew were allowed to keep $100 \%$ of their prizes. ${ }^{165}$ The owners of privateers also did not give their crews wages. Such owners were, however, responsible for paying the bond in addition to all of the costs associated with arming and maintaining their vessels.

The merchants' petitions to the Massachusetts Provincial Congress for letters of marque make it possible to discern which fishing vessels were transformed into privateers during the Revolution. Fish merchants in Marblehead, Massachusetts, for example, constantly petitioned the Congress throughout the war for these commissions. ${ }^{166}$ In all, the Congress granted nineteen letters of marque to Marblehead merchants. The largest number of these commissions by far was

\footnotetext{
163 "Massachusetts Act Authorizing Privateers and Creating Courts of Admiralty,” November 1, 1775, NDAR, Vol. 2, 834-839. Sidney G. Morse has examined the privateer bonds that were filed during the Revolution, and he contends that most bonds were paid not to individual states, but to the Continental Congress. Thus, "Revolutionary privateering" in general, "like the Revolutionary military and regular naval organization, was meant to be a 'Continental' - that is, a national - enterprise.” Sidney G. Morse, "State or Continental Privateers?” The American Historical Review, Vol. 52, No. 1 (October, 1946), 72.

${ }^{164}$ Albion and Pope define "letters of marque" as "armed merchantmen, licensed by the government to pick up prizes only as by-products of normal trading voyages.” They also refer to letters of marque as the official documents licensing these armed merchantmen to take prizes. Albion and Pope, Sea Lanes In Wartime, 24-25. The Provincial Congress seems to have broadly interpreted this second definition of letters of marque to mean licenses for armed commercial vessels to take prizes at any time at sea.

165 On November 25, 1775, the Continental Congress established formal rules regarding prize shares for privateers, colony/state naval vessels, and Continental Naval vessels. The owners of privateers were to get all of the prize money associated with their captures, military or commercial. The colony/state was to get two-thirds of the prize money, and the crew the remainder, for their vessels. This same distribution applied to Continental Naval vessels, with the Continental Congress getting two-thirds of the prize shares. If, on the other hand, "the Capture be a Vessel of War," then in the case of the colony/state or the Congress, the captors received one-half of the prizes. NDAR, Vol. 2, 1133.

${ }^{166}$ See, for example, a petition dated Boston, Nov. 28, 1777, signed by Samuel Trevett of Marblehead, asking that Captain John Conaway be commissioned as commander of the privateer schooner Terrible. MSSRW, Vol. 3, 898; and a petition dated Boston, March 29th, 1782, signed by Benjamin Stacey Glover of Marblehead, asking that Benjamin Ashton be commissioned as commander of the privateer schooner Montgomery. MSSRW, Vol. 1, 317.
} 
given to commanders of converted fishing schooners. Fourteen of the nineteen commissions, or 74\%, were granted for these vessels between 1776 and $1782 .{ }^{167}$ Thirteen schooners belonging to the nearby fishing port of Beverly, Massachusetts were similarly converted into privateers over the course of the war. ${ }^{168}$

A fishing schooner was also used in the first coast guard unit established in Massachusetts in 1775. By August 23, 1775, the people of Machias, in what is today Maine but was then part of Massachusetts' eastern district, had "the armed Schooner Diligent," and "the Sloop Machias Liberty...fixed for the Purpose of guarding the Sea-Coast.” The Provincial Congress put Jeremiah O'Brian in charge of the coast guard vessels, and allocated "the Sum of One Hundred and sixty Pounds, Lawful Money of this Colony, for supplying the Men with Provisions and Ammunition.” The Provincial Congress also "delivered to the said O’Brian, out of the Colony Store, one Hundred Cannon Balls, of three Pounds Weight each, and two Hundred Swivel Balls; for all which, and the Captures he shall make, he is to account with this Court."169

The same schooner Diligent was then used in Massachusetts's own navy. Unlike the schooners fitted out in Beverly that took orders from Washington and were leased to the Continental Congress, and unlike the privateers armed at private expense, the colony/state naval vessels were converted into warships at the colony/state government's expense. The Diligent remained the public property of the Provincial Congress, and the warship’s crew then took their

\footnotetext{
${ }^{167}$ Four letters of marque were given to commanders of brigantines, and one vessel was not identified. For the nineteen petitions, see MSSRW, Vol. 1, 317; Vol. 2, 448; Vol. 3, 898, 906; Vol. 4, 679, 680, 858; Vol. 5, 277; Vol. 6, 817; Vol. 8, 876; Vol. 9, 588, 624; Vol. 11, 309; Vol. 12, 18, 807; Vol. 13, 982; Vol. 14, 984; and Vol. 16, 109.

${ }_{168}$ This figure was gleaned from the list Howe compiled in Beverly Privateers in the Revolution, 405-420.

169 JHRM, Vol. 51, Part I, 96; and NDAR, Vol. 1, 1160-61, 1195. O’Brian made a name for himself as a daring sea captain earlier in May, 1775, when he led the force that repelled a British attempt to secure firewood and lumber in Machias. The engagement took place on land and sea, and resulted in the capture of the H.M.S. Margaretta, which has been called "the first vessel of the Royal Navy to surrender to an American force." Fowler, Rebels Under Sail, 28. Both Fowler and Miller strongly imply that the two Machias vessels and O’Brian were precursors to the U.S. Navy. Fowler, Rebels Under Sail, 26-28; and Miller, Sea of Glory, 29-35. However, in 1775 these vessels were explicitly armed and manned for the purposes of guarding the coast around Machias.
} 
orders and their pay from this government. Because Washington had appropriated the Beverly schooners, the Massachusetts Provincial Congress formed a special committee on December 29, 1775, "to consider and report" on the possibility of arming additional warships at the Congress's expense. ${ }^{170}$ The “Committee for Fitting Out Massachusetts Armed Vessels” reported their findings on January 11, 1776, and the following day the Provincial Congress debated and resolved "that two Ships be built," one of "Thirty-Six Guns” and the other "to carry Thirty-two Guns.”171 However, the Provincial Congress then “re-considered” these resolves on January 29, and at that point "no Establishment has been made for Cruisers." 172 On February 6, the Provincial Congress expanded their naval building program and resolved "That there be built at the Public Expense of this Colony for the Defense of American Liberty, Ten Sloops of War, of One Hundred and Ten Tons, or Fifteen Tons each, suitable to carry from Fourteen to Sixteen Carriage Guns, Six and Four Pounders.” Another special committee was formed at this point, "to provide Materials and employ proper Persons to build said Vessels as soon as may be, for the Purpose abovesaid, and that the Sum of Ten thousand Pounds be delivered to the said Committee, to enable them to proceed in building, rigging, and finishing said Vessels as soon as possible." ${ }^{173}$ As the fleet expanded, the members of the Provincial Congress decided to use vessels they had previously assigned to guard the coast around Machias as a stop-gap measure. On February 7, 1776, the Provincial Congress resolved that "the Sloop Machias-Liberty, and

\footnotetext{
170 “Journal of the Massachusetts Council,” December 29, 1775, NDAR, Vol. 3, 291. The editor, William Bell Clark, considered this date "the beginning of the Massachusetts Navy.” Ibid., footnote \#2. However, no vessels went to sea at this point. Nor were officers commissioned, nor had pay rates been assigned.

171 "Report of the Committee for Fitting Out Massachusetts Armed Vessels," January 11, 1776, NDAR, Vol. 3, 734.

172 JHRM, Vol. 51, Part II, 219; and NDAR, Vol. 3, 1028-1029.

173 JHRM, Vol. 51, Part II, 253-254. This fleet was cut to five sloops on February 16, 1776. See, NDAR, Vol. $3,1315-1316$. It was found to be more cost effective to provide leases to vessel owners rather than to build new vessels.
} 
Schooner Diligent, now lying at Newbury-Port,” be manned with fifty men each. ${ }^{174}$ These vessels had been moved from Machias to Newburyport; given new officers and crews; and their mission was formally changed from coast guard duty to colony/state naval service. Another special committee was then established to recommend officers for these vessels. ${ }^{175}$ The vessel owners received the same leases as the owners of Washington's schooners, with prize shares going to the crew and the Provincial Congress. ${ }^{176}$ This was the beginning of a fleet of vessels that sailed under the Provincial Congress’ control. ${ }^{177}$

Revolutionary leaders effectively used the profit motive to get merchants to invest their capital in the war. From September 1775 to October 1777, the Hannah and seven other schooners like her captured 55 vessels, including eighteen brigs, thirteen ships, fourteen sloops, and ten schooners amounting to over 6,500 tons of shipping capacity. Thus, the British loss amounted to thirty-eight vessels. Eleven captures were judged illegal, as they were found to belong to merchants who were not supplying British forces, and four more were recaptures. The prizes varied in size from a fifteen-ton fishing schooner carrying pilots who were helping the British Navy navigate coastal waters, to the 400-ton merchant ship Concord carrying dry goods

${ }^{174}$ JHRM, Vol. 51, Part II, 256; and NDAR, Vol. 3, 1156. The idea to use these two vessels in the Massachusetts Navy until the other warships could be built may have come from Jeremiah O'Brian in Machias. See, "Petition of Jeremiah O’Brian to the Massachusetts General Court," February 2, 1776, NDAR, Vol. 3, 1095. Indeed, O'Brian was ordered to assist the Newburyport Committee of Safety in manning the two vessels. NDAR, Vol. 3, 1156; and Vol. 4, 63-64.

${ }_{175}$ JHRM, Vol. 51, Part II, 256-257; and NDAR, Vol. 3, 1157. The officers were to "be Commissionated by, and follow such Directions as they shall receive from Time to Time from the Council of this Colony."

${ }^{176}$ With regard to their navy, the Massachusetts Provincial Congress did not get around to officially confirming the Continental Congress's late 1775 legislation until February 7, 1776. JHRM, Vol. 51, Part II, 256-257.

${ }^{177}$ In 1776, there were three vessels being built in Massachusetts: the brigs Rising Empire and Massachusetts, and the sloop Tyrannicide. NDAR, Vol. 4, 259n, 668, 1405; Vol. 5, 1209. Two pre-existing vessels, Washington and Yankee Hero, were also taken into the Provincial Congress's service at this time. NDAR, Vol. 4, 19, 417. "Green \& White" uniforms were established for the colony/state navy on April 29, and "the [ship's] Colors be a White Flag with a Green pine Tree, and an inscription ‘appeal to Heaven.”’ Ibid., 1303. 
and coal to the British forces at Boston. ${ }^{178}$ One of the legal prizes, the brigantine Nancy, contained a cargo valued at "Fifteen Thousand Pounds Sterling," including:

“1 Large brass 15 Inch Mortar already fixed for service;” “a Number” of smaller brass mortars; "a number" of "Brass Cannon from $24 \mathrm{lb}$ down to $4 \mathrm{lb}$, with carriages \&c all ready;" "a number" of iron cannon of equal size and readiness; "2500 Stand of Arms, Bayonets, \& Pouch's complete \&c.;" "30 Tun of [one] ounce [musket] Balls;" "10 Tun of swan shot” for the muskets; "A Great number of carke's already fixed for use to fire the town;" "Large \& small Shot without number;" "A great number of Hogsheads, filled with cartridges in flannel for the cannon mortars, instead of paper;" and "A great number of Hogsheads of cartridges in paper for the small Arms, with everything of this kind we could have wished for." 179

\footnotetext{
${ }^{178}$ See, “Prizes Captured by Washington’s Schooners,” Hearn, George Washington’s Schooners, Appendix, 241; and Clark, George Washington's Navy, 222-224, and Appendix B, "Prizes Taken by Vessels of Washington's Navy," 229-236. The colonists were also very successful at using whaling boats in coastal raids throughout the siege of Boston. On July 24, 1775, Vice Admiral Samuel Graves wrote to the head of the British Admiralty Board: "The Rebels have collected near three hundred Whale Boats in the different Creeks around this Harbor [Boston], and begin to make little Expeditions to the Islands. A few days ago one hundred and five Boats, full of men, landed on Long Island and carried off all the [live]Stock....From their Lightness and drawing little Water, they [the whale boats] can not only out row our Boats, but by getting into Shoal Water, and in Calms, they must constantly escape.” He then observed that "the Design of the Rebels in bringing so great a number of Whale boats here, Robbing the Islands and burning the Houses and Hay thereon" included distressing "the Garrison [at Boston] by depriving them of fresh Meat, Vegetables, Milk, Fruit and many other Advantages.” According to Graves, the large frigates in his squadron were at risk of being boarded and captured by these many whaleboats during the night, as manpower was short. "Vice Admiral Samuel Graves to Philip Stevens, Preston, Boston, July 24, 1775," NDAR, Vol. 1, 961-962. At this early date, it is most likely these whaleboats to which Thomas Jefferson referred when he optimistically wrote to a friend: "The New Englanders are fitting out light vessels of war, by which it is hoped we shall not only clear the seas and bays here of everything below the size of a ship of war, but that they will visit the coasts of Europe and distress the British trade in every part of the world. The adventurous genius and intrepidity of those people is amazing." "Thomas Jefferson to Francis Eppes," Philadelphia, July 4, 1775, NDAR, Vol. 1, 815. More work needs to be done on the whaling industry's conversion during the Revolutionary War. Syrett has provocatively referred to "the whaleboat" as "one of the most effective of American weapons systems." Syrett, "Defeat at Sea," 14.

179 “Edward Green to Joshua Green,” Cambridge, December 3, 1775, NDAR, Vol. 2, 1247. Brigadier General John Thomas was so excited at this prize, that he wrote his wife about it on December 1, 1775: "I have to Inform you of one Thing that is agreeable, viz. one Captain Manly of a Privateer out of Marblehead has brought in to Cape Anne a Fine Large Ship from England Laden with warlike Stores of all Kind Except Powder; a very valuable Prize Indeed; the Particulars I Can't Enumerate. I saw the Invoice which Contains Two Sheets of Paper; this you may Depend that I write nothing of News but what [you] may Rely on for Truth." "Brigadier General John Thomas to His Wife,” Roxbury, December 1, 1775, NDAR, Vol. 2, 1219.
} 
These military stores were meant to supply the British forces at Boston. The armed schooners also stopped provisions from reaching the British military in Boston. ${ }^{180}$ The timing of these captures was important. Twenty-three of the thirty-eight legal prizes were taken in 1775, at the start of the war. These captured vessels contained military stores, clothing, and provisions worth $£ 31,000$, which contributed significantly to the colonist’s ability to wage war. ${ }^{181}$

The Massachusetts Provincial Congress also hired fishing vessels for use on special missions. Such was the case with Salem fish merchant Richard Derby, Jr.'s schooner Quero (most likely named for the Quero Bank of the northeast coast of Nova Scotia). Between April and July, 1775, the Massachusetts Provincial Congress hired Derby's schooner to take "Depositions relative to [the] Battle of Lexington" to Parliament in London. ${ }^{182}$ Similarly, in July, the Provincial Congress approved Salem fish merchant George Dodge’s petition "to export 80 Hogsheads of Old Jamaica Cod-Fish from Salem to the West Indies.” In return for granting this permission, the Massachusetts political leadership demanded Dodge "order the Master of said Vessel to undertake the Conveyance of a Letter or any other Service that this House may think fit to appoint him to.”183 The Salem merchant captain was thus allowed to set sail for profits in return for carrying the Provincial Congress' correspondence.

The British Navy also converted fishing schooners into armed warships during the Revolution. For example, on January 8, 1775, Vice Admiral Graves ordered the purchase of the schooner Diana "of 120 tons, about eight Months old, so exceedingly well built that she is allowed to be the best Vessel of the Kind that has been yet in the King's Service; her first cost is

\footnotetext{
180 "George Washington to John Hancock,” Cambridge, November 30, 1775, NDAR, Vol. 2, 1199. Also, see “Prizes Taken by Vessels of Washington's Navy,” Clark, George Washington's Navy, Appendix B, 229-236.

${ }^{181}$ Clark, George Washington's Navy, 222.

182 "Sch[ooner] Quero. Express to England - to Forestall Gen. Gage’s Dispatch about the Lexington Fight (Successful),” NDAR, Vol. 1, 967-968.

${ }^{183}$ JHRM, Vol. 51, Part I, 15.
} 
$£ 750$ Sterling." "I have thought it best for his Majesty’s Service that she should be an established armed Schooner," he informed the Secretary of the Admiralty Board, therefore "I have directed the necessary alterations to be made in her Hull, and for her to be fitted in all respects like other Vessels of her Class; She will have the St. Lawrence's Guns.” He then appointed one of his family members, Lieutenant Thomas Graves, to command the new warship. ${ }^{184}$ By October, 1775, five of the thirty-five British warships patrolling the coastline of North America were schooners, most of which had probably been fishing vessels in a former life. ${ }^{185}$ In these ways, schooners contributed much to the initial war effort.

\subsection{FROM FISHERMEN TO FIGHTING MEN}

Unemployed commercial fishermen became fighting men during the Revolutionary War. The time they spent at sea on fishing fares and trade voyages gave them practical sailing experience and knowledge of winds and tides, all of which made them better equipped than more land-based workers for maritime military service in privateers and naval vessels. Disaffected and put out of work by the Fisheries Bill, and motivated by a mixture of revenge, the promise of a decent wage, and certain financial bonuses, fishermen flooded the decks of fighting vessels in order to strike a blow at the British Empire. Their familiarity with coastlines, harbors and approaches also made fishermen ideal laborers for building seacoast defenses and serving in coast guard units. Fishermen even fought on land during the war. In short, these maritime laborers participated in a variety of military activities during the Revolution.

\footnotetext{
184 “Vice Admiral Samuel Graves to Philip Stevens,” Preston, Boston, January 8, 1775, NDAR, Vol. 1, 59-60. ${ }^{185}$ NA CO 5/122/35.
} 
Just as the use of commercial fishing vessels for military purposes was an Atlantic tradition not an American invention, so too was the fishing industry seen around the Atlantic as a training school, or "nursery," for fighting men. The enormously successful early modern Dutch maritime complex had been established, according to early seventeenth century English observers, on the foundation of its commercial fishing industry. ${ }^{186}$ "The way to win" economic preeminence and protect it on the European stage was to follow the Dutch model and first develop a large fishing fleet. It was believed that such a commercial armada would provide vessels that could be used in fishing, trading, and warring, along with the manpower and expertise necessary for these activities. The French were able to emulate the Dutch model through their domination of the commercial fisheries around Newfoundland. "The whole increase of the naval greatness of France had its foundation from this trade [i.e. commercial fishing]," an English observer wrote in 1745. He continued: "The French by this trade had so far increased their riches and naval power at that time [i.e. the seventeenth century], as to make all Europe stand in fear of them.”187 England had waged war against the Dutch, built up its fishing industry and navy, waged war against the French, and slowly engrossed the fisheries at Newfoundland. By the mid-eighteenth century, the author of The British Merchant could proclaim: "The history both of France and England will show you that it is since their procuring leave to fish at Newfoundland that they have grown so formidable at sea; that their navy royal

\footnotetext{
${ }^{186}$ See, William Petyt, Britannia Languens (London: 1680); William de Britaine, The Dutch Usurpation (London: 1672); Gerard Malynes, Lex Mercatoria (London, 1622); and Tobias Gentleman, England's way to win wealth, and to employ ships and mariners: or, A plain description of what great profit, it will bring into the common-wealth of England, by the erecting, building, and adventuring of [Dutch herring] busses, to sea, afishing... (London: 1614). For more on the economic success the Dutch experienced, see Jan De Vries and Ad Van Der Woude, The First Modern Economy: Success, Failure, and Perseverance of the Dutch Economy, 1500-1815 (Cambridge: Cambridge University Press, 1997).

${ }^{187}$ Anonymous, Considerations on the Trade to Newfoundland (London, 1745). A contemporary writer referred to the French as "our most prejudicial rivals in the fishery of those parts [i.e. Newfoundland]." Anonymous, A Short Answer to an Elaborate Pamphlet (London: 1731).
} 
has augmented in proportion to the numbers of ships employed in that fishery.” ${ }^{188}$ In the late seventeenth century, Sir Roger L’Estrange observed “The only (and the Common) Nursery of Seamen is the Fishery....And it is well enough observed, that all Princes and States, are stronger or Weaker, at Sea, according to the Measures of their Fishery.”189 And in 1722, William Wood similarly stated: "It is a certain maxim that all states are powerful at sea as they flourish in the fishing trade.”190 Such European precedents firmly linked manpower in the fisheries to naval supremacy. And, as the English explorer and promoter of New World plantation, Sir Walter Raleigh (1554-1618), put it, "he who rules the sea, rules the commerce of the world, and to him that rules the commerce of the world belongs the world itself."191

The correlation between the size of the commercial fishing industry and naval power was also made in the mid-to-late eighteenth-century North American colonies. The number of men and vessels involved in the New England cod fishing industry declined between 1743 and 1763 as a direct result of the use of these resources in the British Navy. ${ }^{192}$ This declension led “Montesquieu” to query in a Boston newspaper in 1763: "What is become of this nursery of sailors, by which [Great Britain] have been of late aggrandized, and rendered the arbitress of the world?"193 In order to convince Parliamentarians not to pass legislation in 1764 and 1767 that they felt would discourage the fishing industry, members of the Boston-based Society for the

${ }^{188}$ The British Merchant, $2^{\text {nd }}$ ed., (London, 1743), II, 257. Cited in Innis, The Codfisheries, 174, footnote \#90.

${ }^{189}$ Sir Roger L'Estrange, A discourse of the fishery briefly laying open, not only the advantages, and facility of the undertaking, but likewise the absolute necessity of it, in order to the well-being, both of king, and people... (London: 1674).

${ }^{190}$ William Wood, A Survey of Trade (London: 1722).

${ }^{191}$ Quote taken from O’Connor, Origins of the American Navy, 2. In the late-nineteenth century, the U.S. Naval officer and historian, Alfred Thayer Mahan, echoed Raleigh's sentiments: "The due use and control of the sea is but one link in the chain of exchange by which wealth accumulates; but it is the central link, which lays under contribution other nations for the benefit of the one holding it, and which, history seems to assert, most surely of all gathers itself riches.” Alfred Thayer Mahan, The Influence of Sea Power Upon History, 1660-1783 (New York: Dover Publications, Inc., 1987; originally published by Little, Brown, and Company, Boston, in 1890), 225-226.

${ }^{192}$ Innis, The Codfisheries, 161.

${ }^{193}$ Boston Evening Post, November 21, 1763. 
Encouragement of Trade and Commerce reminded members of Parliament on both occasions that “This Valuable Branch of our Trade,” our "Fishery,” represented a "Nursery for Seamen.”194 The Society argued that "the North American Cod \& Whale Fishery is a capital Article not only with respect to this Province, as it is their largest Fund for Remittances to Great Britain in payment for British Manufactures, but it's National Importance is conspicuous, not only as by means of it Great Britain is furnished with those Remittances, but also by its employing annually so great a number of vessels it constitutes a respectable Nursery of Seamen for the Navy, a principal Bulwark of the British Nation.” ${ }^{195}$ Then, on December 11, 1781, Boston merchants lobbied Massachusetts' General Court to compel the state's representative in the Continental Congress to guarantee American fishing rights in the North Atlantic in the peace treaty then being written. They couched their demand in the following language:

For though the inhabitants of the other States are not so immediately affected by the Loss of the Fishery, yet we conceive it not less important to the whole Confederacy, than to us, in its political consequences. Their future rank among the Nations of the Earth will depend on their Naval Strength; and if they mean to be a commercial people, it behooves them to be able at all times to protect their commerce. The means by which they can procure that protection and naval strength, is to give encouragement to that kind of trade among themselves, which will best serve as a nursery for seamen. The importance of the Fishery in this

\footnotetext{
194 "In the Preamble to a late Act of Parliament," 1764; and "State of the Trade \& Observations on the Late Revenue Acts," 1767, Ezekiel Price Papers, 1754-1785, MHS. The Society sent the following words to Jasper Mauduit, Massachusetts' colonial agent in London in 1763: "Let it be further Considered that if the Fishery here and at Newfoundland should fail, Great Britain will be deprived of a nursery for Seamen, and in a few years will want hands to Navigate her fleets. At the same time the French will have a fine opportunity to Increase their Fishery, to promote the growth of their Colonies, and put their Navy upon a respectable Footing." Letter from Thomas Cushing to Jasper Mauduit, dated Boston, October 28, 1763, August to December 1763 file, Jasper Mauduit Papers, 17601767, MHS.

${ }^{195}$ Petition from the Society to Parliament, sent through Dennis DeBerdt, colonial agent, dated 1767, Ezekiel Price Papers, 1754-1785, MHS. The link between the fishing industry and "national" defense was recognized earlier in 1746, by William Bollan, Massachusetts' colonial agent in London, who wrote: "It need not be here observed how much this Trade of the Fishery has been the Object of the Attention of the Nation on all Occasions....We look upon it as the chief Nursery for Seamen; and are so much interested in the other Benefits of it, that we annually send one or more of His Majesty's Ships of War, to protect our Subjects, and their Vessels, during the fishing Season.” William Bollan, The importance and advantage of Cape Breton: truly stated and impartially considered (London: Originally printed for J. and P. Knapton, 1746; New York: Johnson Reprint Corp., 1966), 90.
} 
view is obvious from the valuable acquisitions made in the beginning of the war by our privateers, seven-eights of which were manned from this source. ${ }^{196}$

On both sides of the Atlantic, then, throughout the seventeenth and eighteenth centuries fishermen were viewed as potential and actual fighting men.

The mobilization of these maritime workers for war during the American Revolution should come as no surprise. As we saw in the first chapter, Joshua Burnham and the schooner Polly went to work for the Continental Navy shortly after the Declaration of Independence had been signed. Four men joined Burnham on December 7, 1776, in agreeing to "ship ourselves" and "Follow all the regulations of the American Congress \& be under such regulations as is Customary for Seamen \& Mariners.”197 In all, four of the five men - Joshua and Samuel Burnham, Isaac Law, and Daniel Andrews - had been active commercial fishermen in Ipswich prior to the war. ${ }^{198}$ Andrews was born in Ipswich on November 17, 1754, the son of John, Jr., and Mary. ${ }^{199}$ Just before he turned twenty, Andrews worked on the summer and fall fares on board the Polly in 1774 on the Grand Bank off Newfoundland. He caught 1,384 cod in the summer and 901 in the fall. Then, on December 15, 1774, Andrews signed ship’s articles along with four other men to sail on the Polly on a trade voyage to Virginia in order to exchange fish, West Indian sugar products, and salt for beans and wheat. There were three witnesses to "each Man’s Signing," and Andrews earned £1.6.8 per month as a "seaman.” In 1776, by contrast, he

\footnotetext{
${ }^{196}$ Articles of Confederation and Perpetual Union... (Williamsburg, VA: J. Dixon \& W. Hunter, 1778), Early American Imprints, Series I: Evans \#16105.

197 Joshua Burnham Papers, 1758-1817, Schooner Polly, 1771-1776, Box 1, Folder 4, JDPL.

${ }^{198}$ For more on Burnham, see chapter two. Seth Story was the only non-fisherman to sign this document. Story signed on as the schooner’s cooper for £5.6.8 per month. Joshua Burnham Papers, 1758-1817, Schooner Polly, 1771-1776, Box 1, Folder 4, JDPL.

${ }^{199}$ EVREC, Vol.1, 17. His death was not recorded in the vital records.
} 
earned £3.12.0 per month working as a twenty-two year old "seaman” for the Navy. ${ }^{200}$ For his part, Law fished on the schooner Neptune, Joshua Burnham, skipper, for at least one fall fare in 1768. He then went as "seaman" on the same schooner, with Burnham again in charge, on a trade voyage to Virginia between December 1768 and March 1769. Like Andrews, Law earned $£ 1.6 .8$ per month. However, Law was allowed to stow 35 bushels of trade goods in the hold as a “privilege.” In addition, he was forced to pay $£ 0.2 .9$ out of his wages in Greenwich hospital tax. And so, for the entire four months and twelve days "time on board," the fisherman-turnedmariner earned £3.19.4. ${ }^{201}$ By contrast, Law, like Andrews, earned £3.12.0 each month working as a "seaman" for the Navy in $1776 .^{202}$

There are some striking similarities between the two common seamen on board the Polly. Both men worked on local fishing and trading voyages for an Ipswich skipper, and commanded inflated war time wages in Ipswich. Such comparisons tentatively suggest the localized nature of labor pools from which the Navy drew its manpower during the war. Men signed on with captains they knew, on vessels they trusted, for work they were familiar with. Moreover, their earnings history hints at the existence of a narrow labor market in Ipswich that enabled workers to command higher wages during the war. And there is evidence that such increased earnings were not restricted to common seamen. Joshua Burnham, for example, had earned £2.8.0 per month as a "master" for the trade voyage to Virginia at the end of 1774. He then earned £5.8.0 per month as “master” in the Navy. ${ }^{203}$

\footnotetext{
${ }^{200}$ Andrews' fishing, trading, and warring experience can all be found in Joshua Burnham Papers, 1758-1817, Schooner Polly, 1771-1776, Box 1, Folder 4, JDPL.

${ }^{201}$ Joshua Burnham Papers, Schooner Neptune, [c.1766-1770], Box 1, Folder 3, JDPL. There are two fares in 1769 and one in 1770 in which the initials “I.L.” are listed among the fishing crew of the Neptune. Law's birth and death records could not be found. Source checked: EVREC, Vols.1-3.

${ }^{202}$ Joshua Burnham Papers, 1758-1817, Schooner Polly, 1771-1776, Box 1, Folder 4, JDPL.

203 Joshua Burnham Papers, 1758-1817, Schooner Polly, 1771-1776, Box 1, Folder 4, JDPL.
} 
Samuel Burnham was born in Ipswich on November 10, 1754, the son of Thomas and Judith, and he died "an officer in the American army" on March 15, 1782. ${ }^{204}$ At age nineteen, he went with his older relative on two fares each year in 1773 and 1774 to the Grand Bank. During the fall fare in 1773 , he caught 1,478 cod. Over the following summer, he caught 2,000 . Then, in the fall of 1774 he caught 1,083. In 1776, one year after becoming a legal adult, he earned $£ 4.16 .0$ per month as "mate" in the Navy. ${ }^{205}$ Like Andrews, he enlisted in the Navy in his early twenties. However, because of his family connections, Samuel entered at a higher rank and made more money. Collectively, the Ipswich fishermen on board the Polly were not the first, nor were they the last, to make the transition from commercial fishing to naval service.

Fishermen from Marblehead, the foremost fishing port in the thirteen British North American colonies on the eve of the Revolution, also made the transition to fighting men during the Revolutionary War. ${ }^{206}$ The port town employed more men, more vessels, and larger amounts of capital than any other port in the region. If fishermen were going to join the Revolution anywhere in colonial America, they would do so in Marblehead. Indeed, Ashley Bowen, that ubiquitous observer of town events in the fishing port, recorded in his diary on Monday, May 22, 1775, "the fishermen are enlisting quite quick under the Congress [for the Continental Army]." ${ }^{207}$ Such a port community therefore represents the best case study for determining fishermen's military service.

It is extremely difficult to establish the identities of individual workers in early America. Poorer, un-propertied workers do not often show up on tax records, or in inventoried lists upon

${ }^{204}$ EVREC, Vols.1-2, 63, 508.

205 Joshua Burnham Papers, 1758-1817, Schooner Polly, 1771-1776, Box 1, Folder 4, JDPL. It is not immediately clear what Joshua and Samuel's relation to one another. Source checked: EVREC, Vols.1-3.

${ }^{206}$ See, Magra, “'Soldiers... Bred to the Sea',” 538-539.

${ }^{207}$ Smith, ed., The Journals of Ashley Bowen (1728-1813), Vol. 2, 440. 
their death. ${ }^{208}$ Yet, establishing these identities is fundamentally necessary for determining who did what. Merchant account books, probate records, and a useful appendix Phillip Chadwick Foster Smith compiled in The Journals of Ashley Bowen (1728-1813), help to construct a list of laborers who worked in the commercial fishing industry in Marblehead on the eve of the Revolution. ${ }^{209}$ If a person worked on a fishing vessel prior to the war, or if he was from a known fishing port and showed up on in the probate records listed as a fisherman, then his occupational status was recorded as such. By themselves, however, these sources only provide a list of names, residences, and occupations. Frequently, several men with the same name lived in the same town simultaneously. Moreover, a man with a probate filed in 1810 could have been born slightly before, during, or even after the Revolution. Thus, it is essential to triangulate the data compiled in the abovementioned manner with vital records, including birth dates, marriage records, and death records. Even with these records, there are instances when one is left with multiple birth-date possibilities for men with the same name, and it is not possible to isolate the individual being researched. In other cases, no vital records have survived for a given name. And, in certain situations the man was born too late to serve in the war. If any of these examples occurred, then the entry was removed from the database. The remaining list of Marblehead fishermen was then compared with military service records.

These records have been compiled in the massive seventeen-volume Massachusetts Soldiers and Sailors of the Revolutionary War. Here, one can find information on a soldier's

\footnotetext{
${ }^{208}$ According to Alan Kulikoff, who used tax lists to evaluate the widening gulf between rich and poor in colonial Boston, "most fishermen, sailors, and laborers had no taxable wealth at all.” Allan Kulikoff, "The Progress of Inequality in Revolutionary Boston," in Blanche Wiesen Cooke, ed., Past Imperfect: Alternative Essays in American History (New York: Knopf, 1973), 112, 117.

${ }^{209}$ The merchant account books for Marblehead are: William Knight Account Book, 1767-1781, JDPL; Richard Pedrick Account book, 1767-1784, MDHS; Thomas Pedrick Account Book, 1760-1790, MDHS. The probate records can be found in MPR. For Smith's Appendix, see Smith, ed., The Journals of Ashley Bowen (1728-1813), Vol. 2, 639-685.
} 
rank, length of service, commanding officers' identities (typically the company captain and the regimental colonel), and place of enlistment. Maritime service records for privateering, state and Continental Naval service also provide ship classifications, ship names, captain's names, prisoner-of-war status, and prizes taken. In addition, there are lists of men entitled to prize shares and "descriptive lists" of officers and crew members sworn into service These lists detail age, stature, complexion (light, ruddy, sanguine, brown, dark, or black), and on rare occasions, nationality. The descriptions of age and residence can be very helpful in isolating which of the five John Smiths born in Marblehead before the war actually fought in the conflict. In short, this is the single best resource for determining Marbleheaders' military service in the Revolution.

Having said this, the resource has its limitations. The service records do not always specify whether a particular military unit was attached to the local, state, or Continental levels. Likewise, the service records do not consistently detail whether the vessel a man served on was a privateer, a state or a U.S. Naval vessel. These problems can only be mitigated by familiarity with the source, and with the names of commanding officers and particular vessels. Whenever unfamiliar names were encountered, they were added to a separate list along with the man's service record then being examined. Later, when more information about the unfamiliar name could be found in searches for other records, then the unknown schooner could be designated as a privateer, or the unidentified commander could be labeled the Colonel of a Salem militia regiment. The ten volume collection Naval Documents of the American Revolution contributed to identifying certain vessels and military commanders. ${ }^{210}$ In addition, there are oftentimes alternate, phonetic, spellings for surnames in the military service records. This situation necessitates locating such alternate spellings. Then, it is essential to follow-up on each variant

${ }^{210}$ NDAR. 
and verify every record to see if John Smith from Marblehead is the same as John Smyth and John Smithe with different types of military service. Town affiliation, the identity of a subject's commanding officer, and the use of vital records all aid in this process. Whenever town affiliation and the identity of the commanding officer were not provided, names were removed from the database. In those instances when a fisherman's identity could not be concretely matched with the identity of a man who fought in the war, then the man's name was removed from the database. All together, this process of elimination yielded a short $(\mathrm{N}=55)$, but very reliable list detailing the fishermen from Marblehead and the different types of military service they performed, or did not perform, in the Revolution. ${ }^{211}$

We already know a great deal about the Marblehead men who fought in the war. They tended to be younger men in their early-to-mid twenties, with little taxable income or property and an average height of 5'7." While it was typical for 22-35\% of a town's adult male population to participate in the Revolution, Marblehead sent 39\%. Such men commonly reenlisted for at least one more tour of duty after their initial experience in the war. ${ }^{212}$ It has even been suggested that many of these men were fishermen. ${ }^{213}$ However, to date, no one has demonstrated the occupational status of fighting men from Marblehead, nor has anyone discussed the linkages between this status and the different types of military service Marbleheaders performed.

\footnotetext{
${ }^{211}$ To date, the most comprehensive study of Revolutionary soldier's pre-war occupational identities relies on a data set of 43 men. Edward C. Papenfuse and Gregory A. Stiverson, “General Smallwood's Recruits: The Peacetime Career of the Revolutionary War Private,” William and Mary Quarterly, Third Series, Vol. 30, No. 1 (January, 1973), 117-132.

212 Sargent, “Answering the Call to Arms,” 226, Table 6.5, 228, Table 6.8, 229, Figure 6.9, Table 6.10, 232, Table 6.12; and Baller, "Military mobilization during the American Revolution in Marblehead and Worcester, Massachusetts,” 20, 27-28, 366, Figure 4, 367, Figure 5. For the typical town mobilization percentages outside Marblehead, see Higginbotham, The War of American Independence, 389-390.

213 Baller, "Military mobilization during the American Revolution in Marblehead and Worcester, Massachusetts,” 13-14; and Billias, General John Glover and His Marblehead Mariners, 59.
} 
Of those men who were positively identified as having worked in the commercial cod fishing industry prior to the Revolution ( $\mathrm{N}=55)$, $82 \%$ could be documented as having fought in the war in some capacity. ${ }^{214}$ This participation rate represents two-to-four times the typical rate for most towns during the war, suggesting that fishermen as an occupational group mobilized in very high numbers during the conflict. Such involvement is not surprising given the fact that the Fisheries Bill specifically targeted the commercial fishing industry.

Of the Marblehead fishermen who did military service in the war $(\mathrm{N}=45), 78 \%$ performed some service at sea, including work in the coast guard, the Massachusetts Navy, the Continental Navy, and on privateers. In their work in the coast guard, fishermen were responsible for building and manning seacoast defenses during the war. ${ }^{215}$ These defenses consisted primarily of forts constructed at harbor entrances. Built of breastworks and field pieces, the forts guarded inbound and outbound vessels, and prevented British warships from entering coastal waters unchallenged. Permanent coast guard units were stationed in these defensive positions for the duration of the war. ${ }^{216}$ Marblehead, for example, maintained three “Sea Coast Defense” companies, consisting of fifty men in each company. ${ }^{217}$ In 1775 , the men earned the following wages: Captains earned $£ 5.8 .0$ each month; $1^{\text {st }}$ Lieutenants $£ 3.12 .0 ; 2^{\text {nd }}$ Lieutenants £3.3.0; Sergeants £2.4.0; Corporals, Fifers, and Drummers each earned £2.0.0; and Privates earned “\$36 [roughly £0.18.0] per month.”218

\footnotetext{
${ }^{214}$ A few fishermen $(\mathrm{N}=2)$ worked only on privateers, and they were included in the database. This decision was made on the justification that these men risked their lives to contribute to the war effort.

${ }^{215}$ Magra, “'Soldiers....Bred to the Sea',” 554.

${ }^{216}$ See the discussion above.

${ }^{217}$ The three companies were: Captain Francis Felton's $1^{\text {st }}$ Sea Coast Defense Company; Captain William Hooper's $2^{\text {nd }}$; and Captain Edward Fettyplace's $3^{\text {rd }}$. See, MSSRW, Vol. 5, 605, 641; Vol. 8, 230. For the size of these companies in 1775 and 1776, see JEPCM, 412-413; and JHRM, Vol. 51, Part II, 87-91, 96, 112.

${ }^{218}$ JEPCM, 413. The conversion rate of $\$ 1=6$ pence in Massachusetts in 1775 is drawn from John Glover's Colony Ledger, MDHS, item \#7291/2.
} 
As mentioned above, the coast guard units also maintained vessels for use in patrolling harbors and harbor mouths. Like the two Machias coast guard vessels, other vessels made captures at sea and seized supplies meant for the British military. On June 12, 1776, for example, Nathan Smith reported that he and "other persons belonging to a Sea-coast company, stationed on the Island of Martha's Vineyard," captured “and brought into port, the Bedford, a schooner, laden with provisions and other stores, for the fleet and army.” Smith petitioned the Provincial Congress for a share in the prize, in return "for their risk and service." ${ }^{219}$ Apparently, a system of prize shares had not yet been codified for the coast guard units. The men in these units, however, operated in the expectation of prize money.

Marblehead fishermen such as Twisden Bowden served in the coast guard. The Bowden family had been very involved in the port's fishing industry prior to the war. Twelve different Bowdens worked for either William Knight or the Pedrick brothers during the 1760s and early 1770s. ${ }^{220}$ Twisden was born March 17, 1745, and he married into the family of a prominent local fish merchant at age twenty. ${ }^{221}$ He worked for Knight on at least two fares in 1770 as a sharesman on board the schooner Barnett, Robert Knight, Jr., skipper. For fishing that year, Bowden earned £33.0.8. ${ }^{222}$ Thirty-years old and married, he enlisted as a Sergeant in Captain William Hooper's Second Marblehead Sea Coast Defense Company on July 15, 1775, and served in this capacity until December 31, 1775. His family status may have influenced his decision to join a local coast guard unit as opposed to the Continental Army, which would have taken him away from town for long periods of time. As a Sergeant in the coast guard, he would have

${ }^{219}$ JHRM, Vol. 52, Part I, 28.

${ }^{220}$ William Knight Account Book, 1767-1781, JDPL; Richard Pedrick Account book, 1767-1784, MDHS; and Thomas Pedrick Account Book, 1760-1790, MDHS. Twisden was also described as a fisherman on a probate filed for him on November 7, 1787. MPR.

${ }^{2221}$ EVREC, Vols. 1-2, 59, 46. He married Sarah Orne on December 19, 1765.

${ }^{222}$ William Knight Account Book, 1767-1781, JDPL. 
earned £2.4.0 per month, or £13.4.0 for the six months. Bowden then enlisted for a second tour of duty in Hooper's company on January 4, 1776, served for another eight months, and earned an additional £17.12.0. Up to this point, then, he had earned £30.16.0 for fourteen months of coast guard duty, which was comparable to his earnings while fishing. The following year he served in Captain Edward Fettyplace's Third Marblehead Sea Coast Defense Company. At some point in 1777, while attempting to make a capture at sea and earn additional prize money, Bowden was himself captured by the British Navy and sent to a prison in Halifax, Nova Scotia. In December he was released in a prisoner exchange, and he does not appear to have gone back into the military. ${ }^{223}$ Such men contributed to the military defense of the coast during the war, and their service has gone largely unexplored. ${ }^{224}$

Other fishermen fought in Massachusetts's navy. Eleven states had their own navies during the war. ${ }^{225}$ As discussed above, Massachusetts began arming vessels in 1775 and formally established its own navy in February, 1776. The wages for the officers and men in the Massachusetts navy were as follows: Captains earned $£ 4$ each month; $1^{\text {st }}$ Lieutenants made $£ 3$ per month; $2^{\text {nd }}$ Lieutenants and Surgeons each earned $£ 2.10 .0$ per month; Masters earned £2; Boatswains, Carpenters, Gunners, Pilots, Quartermasters, Stewards, Master-at-Arms all earned $£ 1.10 .0$ each month; while "Foremast Men” made £1.4.0 per month. In addition to these wages, and for "further Encouragement to the said Officers and Seamen," the crew was to receive "one

${ }^{223}$ MSSRW, Vol. 2, 320.

${ }^{224}$ To date, no scholarly article or book-length study has been done on the sea coast defense companies that served in the American Revolution.

${ }^{225}$ New Jersey and Delaware were the exceptions. O’Connor, Origins of the American Navy, 14; and Albion and Pope, Sea Lanes In Wartime, 39. For an argument that both of these states did have their own navies, see Robert L. Scheina, “A Matter of Definition: A New Jersey Navy, 1777-1783,” The American Neptune, Vol. 39, (July, 1979), 209-218. More work needs to be done on these state navies to determine precisely how many vessels were involved; which type of vessels; and to develop crew lists for those vessels. 
Third the Proceeds of all Captures."226 Such prize shares provided a lucrative incentive over and above wages that were already attractive for unemployed fishermen.

Thomas Johnson fought in this regional navy. He was born on March 30, 1755. At age thirteen, he worked for Thomas Pedrick as a cuttail on at least one fare on board the Marblehead schooner Vim. Johnson earned £7.6.11 for this fare. ${ }^{227}$ After the Massachusetts navy was formed in 1776, he signed-on as a seaman on board the state brig Massachusetts at the first opportunity in 1777. Johnson continually re-enlisted, and served on three cruises under two different commanders for a total of six-and-a-half months. ${ }^{228}$ Given the monthly rate for forethe-mast men in Massachusetts’s navy of $£ 1.4 .0$, Johnson earned $£ 7.16 .0$ for his time in this sort of service, plus a share of any prizes that were taken.

Out-of-work fishermen could also earn money fighting in the Continental Navy. The Hannah, and others like her, held out to maritime laborers enormous potential for profits. These vessels took prizes at sea and crews earned profits from prize shares over and above their individual wages, which were already inflated in certain ports due to the war. In Salem, Massachusetts in 1753, just before the Seven Years' War, masters of schooners on trading missions earned £1.17.4 per month; mates £1.12.0; and mariners £1.6.8. ${ }^{229}$ In Ipswich, Massachusetts in 1774, on the eve of the Revolutionary War, similar masters earned £2.8.0 per month; mates £1.12.0; and mariners £1.6.8. ${ }^{230}$ While the pay rates for the Hannah’s crew have not survived, the crew on board the Connecticut armed brig Minerva in August, 1775, earned the following wages: the captain made £7.0.0 per month; the $1^{\text {st }}$ lieutenant £5.0.0; the $2^{\text {nd }}$ Lieutenant

\footnotetext{
${ }^{226}$ JHRM, Vol. 51, Part II, 256-257; and NDAR, Vol. 3, 1157.

${ }^{227}$ Thomas Pedrick Account Book, 1760-1790, MDHS.

${ }^{228}$ MSSRW, Vol. 8, 964.

${ }^{229}$ Schooner Molly, 1751-57, Box 7, Folder 10, Timothy Orne Shipping Papers, JDPL.

${ }^{230}$ Schooner Polly, 1771-1776, Box 1, Folder 4, Joshua Burnham Papers, 1758-1817, JDPL.
} 
$£ 4.0 .0$; the master £4.0.0; the mate £3.0.0; the gunner £3.0.0; the gunner’s mate £2.8.0; the boatswain £3.0.0; the boatswain’s mate £2.8.0; the steward £3.0.0; the cook £3.0.0; the carpenter $£ 3.0 .0$; along with forty seamen who earned £2.5.0 per month; and forty marines, soldiers serving at sea at this point, who earned £2.0.0 per month. The seamen and marines were also to be offered one month's wages in advance prior to "any cruise in said service." ${ }^{231}$ Around the same time, the Continental Congress in Philadelphia established the following pay scale for the American Navy: Captains earned £9.2.0 per month; Naval “Lieutenants” £6; Masters £6; Mates $£ 4.10 .0$; Boatswains £4.10.0; Boatswains’ first mates £2.16.0; Boatswains’ second mates £2.8.0; Gunners £4.10.0; Gunners’ mates £3.4.0; Surgeons £6.8.0; Surgeons’ mates £4.0.0; Carpenters $£ 4.10 .0$; Carpenters’ mates £3.4.0; Coopers £4.10.0; Captain’s clerks £4.10.0; Stewards £4.0.0; Chaplains £6; Able seamen £2; Captain of marines £8; Marine lieutenants £5.8.0; Marine sergeants £2.8.0; Marine Corporals £2.4.0; Fifers £2.4.0; Drummers £2.4.0; and "privates or marines” $£ 2 .{ }^{232}$ Such war-time inflation of maritime wages was typical throughout the eighteenth century Atlantic world in those labor markets in which naval authorities and merchants competed for manpower. ${ }^{233}$ However, in Massachusetts on February 7, 1776, the crew of the armed schooner Diligent, "now lying at Newbury-Port," was given the following rates: the Captain earned $£ 4$ per month; 1st Lieutenant, £3; 2nd Lieutenant, £2.10.0; Surgeon,

\footnotetext{
231 "Minutes of the Connecticut Council of Safety," Lebanon, August 3, 1775, NDAR, Vol. 1, 1052-1054. At this time, a system was laid out for requisitioning funds for this naval service, and a protocol for offering commissions was established. In effect, Connecticut had its own navy. The Continental Congress formally established a national Marine Corps on November 10, 1775. See, Morison, John Paul Jones, 36.

232 "Rules for the Regulation of the Navy of the United Colonies," Philadelphia, November 28, 1775, in NDAR, Vol. 2, 1178. These figures have been converted from their dollar amounts using the conversion supplied in Glover's ledger for August 24, 1775: \$1 = 6 shillings. John Glover's Colony Ledger, MDHS, item \#7291/2.

${ }^{233}$ Marcus Rediker, Between the Devil and the Deep Blue Sea (Cambridge: Cambridge University Press, 1987), 121-124. Vickers maintains that prior to the Revolution merchant mariners in Salem were not given higher wages during wartimes, as opposed to their counterparts in England. This contrast, he believes, was due principally to the fact that the British Navy sailed out of England each year and frequently pressed workers from the merchant marine in local, not colonial, ports. Daniel Vickers, Young Men and the Sea: Yankee Seafarers In the Age of Sail (New Haven, Conn.: Yale University Press, 2005), 81-82.
} 
$£ 2.10 .0$; Master, £2; the Boatswain, Carpenter, Gunner, Pilot, Quarter-Master, Steward, and Master at Arms each earned £1.10.0; while the "Foremast Men” earned £1.4.0. ${ }^{234}$ Such earnings did not compare favorably to the peacetime wages listed above. Thus, recruiters in Connecticut and Philadelphia may have had a more difficult time securing manpower for their naval forces than Massachusetts during the war. Whether or not these wages were higher or lower in wartime, they were all supplemented with prize money.

In order to encourage the "Activity, and Courage” of her crew, Washington spelled out the distribution of prize money the Hannah's crew would receive "over and above your Pay in the Continental Army."235 First, the prize was to be sent "to the nearest and safest Port," and the commander-in-chief informed "immediately of such Capture, with all Particulars and there to way my further Direction.” As of yet, no Admiralty courts had been established for the adjudication of legal prizes. ${ }^{236}$ In effect, Washington was telling the Hannah's crew that he

${ }^{234}$ JHRM, Vol. 51, Part II, 257.

235 “George Washington’s Instructions to Captain Nicholson Broughton,” September 2, 1775, NDAR, Vol. 1, 1288. On April 9, 1776, Massachusetts raised eight companies for the Continental Army. The following represents the monthly pay scale at that time: "To the Colonel, twelve Pounds; to the Lieutenant Colonel, nine Pounds twelve Shillings; to the Major, eight Pounds; to each Captain, six Pounds; to each First-Lieutenant, four Pounds; to each Second-Lieutenant, three Pounds ten Shillings; to each Sergeant, forty-eight Shillings; to each Corporal and Drummer, forty-four Shillings; to each Fifer and private Soldier, forty Shillings.” The men were further allowed "for their Return Home, that is to say, at the Rate of one Day for every twenty Miles Travel; also there shall be allowed one Penny per Mile to each Man, to compensate his Expenses in his Travel to the Place of Rendezvous, and at the same Rate to bear his Expenses to the Camp, to be paid by himself." Also, each "Non-commissioned Officer and private Soldier" were to be given "a good effective Fire-Arm and Bayonet, a Cartridge-Box, Knapsack and Blanket; and no Non-commissioned Officer and private Soldier, shall be allowed to pass Muster, without he is so equipped and provided.” JHRM, Vol. 51, Part III, 99, 100. The Hannah's crew had been literally drummed out of the Army from Glover's regiment, as Homan noted in his pension record cited above. For this reason, Morison refers to the Hannah and her sisters as the "Army's Navy." Morison, John Paul Jones, 35. He does not explain how Washington could be the "Founder of the United States Navy," while this initial fleet was the "Army's Navy." Indeed, Morison further complicates the matter by referring to October 9, 1775, the date the Continental Congress established a seven-man Naval Committee, as “the birthday of the Continental and United States Navies.” Ibid., 36.

${ }^{236}$ Thomas Cushing, a Boston merchant and Massachusetts delegate to the Continental Congress, wrote to a friend on October 23, 1775: "I am glad to find General Washington is fitting out some vessels of war. This is a necessary measure, as our enemies are daily pirating our vessels. I have frequently urged it here. As to the establishment of Courts of Admiralty, that will come on of course; but it will not do to urge it here at present." Thomas Cushing to William Cooper, Philadelphia, October 23, 1775, Massachusetts Historical Society Collections, Fourth Series, Vol. IV, (Boston: Little, Brown, and Company, 1858), 365. 
would be their ultimate judge. In the event that a prize was judged legitimate, meaning that it was neither a re-capture nor a vessel belonging to a Patriot merchant, the crew was to earn onethird of the value of whatever cargo was taken on a prize ship, except "military and naval stores.” These things, along "with vessels and apparel are reserved for public service.” In addition, the Continental Congress, which had paid for the conversion of the fishing schooner, and Washington, as their commander-in-chief, received two-thirds of the cargo's remaining value. Washington then divided the crew's one-third share in the following manner: the Captain earned six shares of the one-third; the $1^{\text {st }}$ Lieutenant earned five shares; the $2^{\text {nd }}$ Lieutenant four; the "Ship’s Master” 3; the Steward 2; the Mate 1.5; the Gunner 1.5; the Boatswain 1.5; the Gunner’s Mate and the Sergeant each earned 1.5; and the "Privates" earned a singe share. ${ }^{237}$

Such prize shares could amount to a princely sum for workers. In 1777, the armed schooner Franklin and her crew captured the powder ship Hope. The Hope's precious cargo was valued at $£ 54,075.17 .2$, one third of which amounted to $£ 18,025.5 .8$. One of the common crewman’s shares for this prize, taken from the one third, was worth $£ 487.3 .4$, or eight years of work in the commercial fishing industry for the most experienced sharesmen. ${ }^{238}$ In this way, a huge sum of money might be offered as an incentive for unemployed, poorer working men to go to sea to capture British military supply vessels and smaller warships. ${ }^{239}$ Such incentives came

\footnotetext{
237 “George Washington’s Instructions to Captain Nicholson Broughton,” September 2, 1775, NDAR, Vol. 1, $1,288$.

${ }^{238}$ The American government only provided the crewmen with half their legitimate shares, or £243.11.8. Clark, George Washington's Navy, 221.

${ }^{239}$ Poorer workers did not solely rely on fishing schooners for these captures. Between October 9 and November 11, 1775, the Massachusetts Provincial Congress debated and resolved an "Act for encouraging the fitting out armed Vessels.” JHRM, Vol. 51, Part I, 151-152, 216, 250, 264, 271. The Act included a clause that encouraged "the Confiscation of all armed and other Vessels, that shall be taken and brought into this Colony, together with their Cargos, Appurtenances, \&c. which shall have been found making unlawful Invasions, Attacks or Depredations on our Sea Coasts or Navigation, or improved in supplying the Enemy with Provisions, \&c. or employed by them in any other Respect whatever." Moreover, the Act mandated "that all Vessels and Cargoes that shall be taken by said Inhabitants or others, properly authorized to take the same, and that shall be legally condemned in this Colony, shall be the Property of the Captors, they paying the Charges of Condemnation.”
} 
on top of bounties men had previously qualified for through their enlistment in the Continental Army. $^{240}$

Marblehead fishermen such as Richard Tutt, Jr. signed-on for cruises in the American Navy during the Revolution. Tutt was the son of a fisherman. He was born on February 11, 1759, and while records of his fishing exploits have not survived, he is listed in probate records as having lived his life as a fisherman. ${ }^{241}$ Tutt enlisted in the Marblehead regiment at the start of the Revolution, and fought on land until March 20, 1776. At some point after that, he signed-on as seaman on board the "U.S.” brigantine General Gates, John Skimmer, captain. His name appears on a list of men entitled to prize shares. Tutt was promised 1.25 shares of the crew's one-third share in addition to his monthly wage of $£ 2 .^{242}$

Finally, the Act called for the establishment of "a Court for the Trial and Condemnation of all Vessels, Cargoes, \&c. as aforesaid, that shall be taken and brought into this Colony." Ibid., 151-152. According to a letter written from Elbridge Gerry to John Adams, dated Watertown, December 4, 1775, this act unleashed a wave of profit seekers against the British military. Gerry wrote: "The late Act of Resolve for encouraging the fitting-out of Armed Vessels in this Colony I apprehend will have a good Effect, having already animated the Inhabitants of the Seaports who were unable to command much property, to unite in Companies of twenty or thirty Men \& go out in Boats of 8 or 10 Tons Burden, which they call 'Spider Catchers.' One of these the last Week brought in two Prizes; the last of which was a Vessel of 100 Tons from Nova Scotia, loaded with potatoes \& 8 or 10 head Cattle.” Elbridge Gerry to John Adams, Watertown, December 4, 1775, Elbridge Gerry Papers II, 1770-1848, MHS.

${ }^{240}$ It was common in 1775 for men to receive "a bounty coat or its equivalent in money" for enlisting in the Continental Army. See, for example, the service records for Thomas Barker, MSSRW, Vol. 1, 504, 622; Thomas Brown, MSSRW, Vol. 2, 692; and George Cash, MSSRW, Vol. 3, 187-188. On July 5, 1775, the Massachusetts Provincial Congress had ordered 13,000 coats "made of good plain cloth...in the common plain way, without lapels, short, and with small folds." JEPCM, 456-457. As a cost-saving measure, the practice of giving men coats was abandoned at the end of 1775 and the beginning of 1776, as the responsibility for clothing the Continental Army shifted from the Massachusetts Provincial Congress to the Continental Congress. According to Washington, "the Continental Congress" ordered "Hunting Shirts as an outside Dress - under which, a warm Waistcoat will be cheaper, and more convenient.” George Washington to the Massachusetts General Court, Cambridge, August 12, 1775, in PGW, Vol. 1, 297. The Provincial Congress had supplied troops with "Shirts, Shoes, and Stockings, Breeches and Waistcoats” in 1775. General Orders, Cambridge, August 24, 1775, in PGW, Vol. 1, 357. Additionally, prior to the Continental Congress' adoption of the army laying siege to Boston, the Massachusetts Provincial Congress offered men advance pay of 40 shillings on May 20, 1775, as an incentive to fight. JEPCM, 246. The Continental Congress experimented for a short time in 1776 with eliminating recruiting bounties. However, the resulting lack of interest in military service soon brought the bounties back. Royster, A Revolutionary People At War, 64-65.

${ }^{241}$ EVREC, Vol. 1, 527; and MPR.

${ }^{242}$ MSSRW, Vol. 16, 201. For the monthly wage of seamen in the U.S. Navy at the end of 1775, see footnote \#232 above. Tutt's “seaman's” share was slightly higher than the "private's” single share on board Washington's schooners in 1775. See footnote \#237. 
Fishermen also engaged in privateering during the American Revolution. William Le Craw was born into a (most likely French, Jersey Island) fishing family in Marblehead on May 26, $1736 .^{243}$ Two other Le Craws can be found listed in probate records as having worked as fishermen in Marblehead, including Phillip Le Craw, who worked as a sharesman and skipper for William Knight on board the schooner Molly in the 1760s. ${ }^{244}$ Like Phillip, William probably became a skipper prior to the outbreak of war. Unfortunately, the records of William's career in the fishing industry beyond his probate record have not survived. However, he commanded two Marblehead privateers during the war: the schooner Necessity (1776), and the brig Black Snake (1777). And fish merchants and vessel owners such as John Selman and Joshua Orne, who owned Necessity, would not have trusted their property and their enterprise to someone with little experience. $^{245}$ As captain of these privateers, Le Craw would have enjoyed the highest share among the crew of any prizes taken. ${ }^{246}$

While it might be expected that fishermen would fight at sea, 76\% of those Marblehead fishermen who fought in the war performed military service on land. The local militia regiment provided the first way by which fishermen could supplement or replace the earnings they had lost as a result of the Fisheries Bill. As discussed above, some members of the Marblehead regiment left the ranks to board Washington's schooner fleet at the end of 1775 . Others re-

\footnotetext{
${ }^{243}$ He died September 20, 1802 at age 66 years, 3 months, 25 days. He was listed as "Captain." A probate was filed for him on October 13, 1802. EVREC, Vol. 2, 601; and MPR. It was not uncommon for French fishermen from the island of Jersey to settle in Marblehead in the eighteenth century. Christine Leigh Heyrman, Commerce and Culture: The Maritime Communities of Colonial Massachusetts, 1690-1750 (New York: W.W. Norton \& Company, 1984), 214, 246.

${ }^{244}$ William Knight Account Book, 1767-1781, JDPL; and MPR.

${ }^{245}$ MSSRW, Vol. 9, 624; and Smith, ed., The Journals of Ashley Bowen (1728-1813) of Marblehead, Vol. 2, 664-665. Orne and Selman petitioned the Massachusetts Provincial Congress "that the Commissary General grant him [i.e. William Le Craw] 200 pounds of powder and 200 grape-shot from the laboratory at Boston as he could obtain none at the forge." The Congress, however, ordered "that the Commissary General deliver 200 pounds of powder from the powder-mill at Andover and 200 grape-shot from the laboratory at Boston to said Orne, he paying for the same.” MSSRW, Vol. 9, 624.

${ }^{246}$ For first-hand accounts of life on board a privateer during the Revolution, see Sidney G. Morse, "The Yankee Privateersman of 1776,” The New England Quarterly, Vol. 17, No. 1 (March, 1944), 71-86.
} 
enlisted in the regiment when Washington re-organized the Continental Army in January, 1776.

The Marblehead regiment took leading roles in some of the most famous events of the war. ${ }^{247}$ Marbleheaders served in a supporting role at the Battle of Bunker Hill; fought on Long Island, and at Pell's Point during the White Plain's retreat; they fought at Trenton; it was their reconnaissance work that led to the capture of British General John Burgoyne at Saratoga; and later they fought to retake Rhode Island from the British. Moreover, Marblehead fishermen were responsible for certain inland maritime activities, such as evacuating Washington and the Continental Army from Long Island and transporting those same land forces across the Delaware River prior to the Battle of Trenton.

Joseph Courtis fought on land during the Revolutionary War. He was born on October 31, 1756. ${ }^{248}$ At age seventeen, he worked for William Knight as a cuttail on board the schooner Molly, Robert Knight, Jr., skipper, for four fares. Courtis earned £34.18.0 for fishing in 1773 . $^{249}$ Two years later, he enlisted as a private in Captain Joel Smith's Company One of the 21st Massachusetts Regiment of Foot in the Continental Army under the command of Colonel John Glover on July 24, 1775. His name appears on a muster roll for August and on a company return for October. Courtis was then in the Continental Army camp at Cambridge, Massachusetts on December 20, when he applied for “a bounty coat or its equivalent in money."250 Working as a private in the Army he earned $£ 2$ per month, $£ 10$ over five months in addition to his bounty. ${ }^{251}$ The Army was the first alternative employer for out-of-work fishermen in 1775. Comparable pay and the promise of prize shares lured men into sea service as the war dragged on.

\footnotetext{
${ }^{247}$ For more on the Marblehead regiment’s military accomplishments, see Magra, “'Soldiers... Bred to the Sea',” and Billias, General John Glover and His Marblehead Mariners.

${ }^{248}$ EVREC, Vol. 1, 128.

${ }^{249}$ William Knight Account Book, 1767-1781, JDPL.

${ }^{250}$ MSSRW, Vol. 4, 265.

251 This pay rate is based on the wages established on April 9, 1776. JHRM, Vol. 51, Part III, 99,
} 
Slightly more than half (53\%) of the fighting fishermen from Marblehead fought on both land and sea. Like those in the coast guard, they performed military service on both elements. William Main, for example, was born on October 12, $1740 .{ }^{252}$ At twenty-nine years of age he worked on an unspecified number of fares for Richard Pedrick, and earned £22.11.4. ${ }^{253}$ On February 20, 1776, Main enlisted as a matross, a gunner’s assistant who aided in loading, firing, sponging and moving the guns, in Captain Fettyplace's sea coast defense company. Given his title, it is most probable that Main spent a majority of his time in the fort guarding Marblehead's harbor. He served six months and ten days "in defense of the seacoast." Assuming the pay for a matross in Massachusetts's coast guard in 1776 was equivalent to that of a private in the same type of unit in 1775 (£0.18.0 per month), Main earned roughly £5.14.0. Such money may not have impressed the fisherman, and it is possible he was eager to get out of the coast guard, for eleven days before his tour of duty expired, Main signed on as a private (most likely in a marine company as his rank was not that of seaman) on board the brigantine Massachusetts, Daniel Souther, captain, in the Massachusetts state navy. He served in this capacity, probably hoping for a chance at prize money, from August 19 to December 21, 1776. Assuming he earned the same as a fore-the-mast man, £1.4.0 per month , Main made roughly £4.16.0. ${ }^{254}$ In total, Main earned $£ 10.10 .0$ for almost a year fighting on land and sea. Main’s dual military service was typical. He and other Marblehead fishermen were among the first Marines in American history. ${ }^{255}$

\footnotetext{
${ }^{252}$ He died on January 29, 1816, "in an Advanced Age." EVREC, Vol. 1, 330; Vol. 2, 608. A probate was filed for him on October 1, 1816, and he is listed there as a fisherman. MPR.

${ }^{253}$ Richard Pedrick Account book, 1767-1784, MDHS.

${ }^{254}$ MSSRW, Vol. 10, 142, 143.

${ }^{255}$ Magra, "'Soldiers...Bred to the Sea'," 556-557; and Charles R. Smith, Marines in the Revolution: A History of the Continental Marines in the American Revolution, 1775-1783 (Washington, D.C.: History and Museums Division, Headquarters, U.S. Marine Corps, 1975), 12, 32-33, 80.
} 
Not every fisherman in Marblehead participated in the Revolution. There are several reasons why $18 \%$ of Marblehead's fishermen did not fight in the war. Age played a significant role in a man's decision to not fight. Of those who did not serve $(\mathrm{N}=10)$, the average age was 32. This was higher than the average age of those who did serve $(\mathrm{N}=45)$, which was 26. Significantly, cod fishermen typically were the most physically productive in catching fish, and thereby reached their peak earning potential, between the ages of $25-30 .^{256}$ In other words, the Marblehead fishermen who fought lost more as a result of the Fisheries Bill. Those over the age of thirty, by contrast, were usually realizing fewer and fewer profits from the fishing industry. There were also minors such as thirteen-year-old Thomas Ingalls, and fifteen-year-old Thomas Dolliber, whose parents or legal guardians may have been prevented them from serving. Sixteen was the standard age young lads were allowed into militias, although there were boys under sixteen in the armed forces during the war. ${ }^{257}$ Political preference and patriotic devotion to the Empire may have played a role in this decision. ${ }^{258}$ Yet, it is not clear why even the staunchest Briton working in the colonial fishing industry would chose to support the government that had stripped away his livelihood. It is also possible that those who did not fight maintained religious ties to the Church of England, were pacifists, or simply wanted to remain neutral. ${ }^{259}$ Ashley

${ }^{256}$ Vickers, Farmers and Fishermen, 178-180, esp. Figure 2.

${ }^{257}$ Soldiers were also supposed to be taller than 5'2.” Higginbotham, The War of American Independence, 391.

${ }^{258}$ Linda Colley argues that laboring peoples in eighteenth century England developed a sense of British nationalism from anti-French, anti-Catholic sentiments. Linda Colley, Britons: Forging the Nation 1707-1837 (New Haven, Conn.: Yale University Press, 1992).

${ }^{259}$ Robert M. Calhoon, the dean of historians of Loyalism, has suggested that Loyalists' motivation cannot be reduced to a single factor. Robert M. Calhoon, Timothy M. Barnes, and George A. Rawlyk, eds., Loyalists and Community in North America (Westport, Conn.: Greenwood Press, 1994); Robert M. Calhoon, The Loyalist Perception and other Essays (Columbia, S.C.: University of South Carolina Press, 1989); and idem., The Loyalists in Revolutionary America, 1760-1781 (New York: Harcourt Brace Jovanovich, 1973). For an argument that emphasizes commercial ties to Great Britain in order to explain Loyalism, see Edward Countryman, "The Uses of Capital in Revolutionary America: The Case of the New York Loyalist Merchants," William and Mary Quarterly, 3rd. Ser., Vol. 49, No. 1 (January, 1992), 3-28. 
Bowen, a Marblehead fisherman turned ship rigger, took the last of these positions. ${ }^{260} \mathrm{He}$ explained his rationale for this decision in the form of a poem:

As for opinions, I confess

I never upon them laid stress

Sometimes a Whig, sometimes a Tory

But seldom steadfast in one story.

The reason is, I'm not yet fixed

So my religion is but mixed. ${ }^{261}$

Bowen, it should be emphasized, supported the fishing industry as a ship rigger. He had stopped going to sea by the time of the Revolution. In addition, during the Seven Years' War he served in the British Navy and genuinely enjoyed the experience. It should also be stressed that Bowen did not go out of his way to convince his neighbors not to resist British authority. Those who chose to publicly support the Crown and Parliament were persecuted and ridden out of Marblehead very early in $1775 .^{262}$

There is no evidence of African-American fishermen having served in the war, but then again there is very little evidence of African-Americans working in the cod fishing industry. ${ }^{263}$ However, there is strong evidence that African-Americans served in the Marblehead regiment. ${ }^{264}$ In addition to the pension record for a freed slave named Cato Prince, who fought in the Revolution, Alexander Graydon, an officer in the Continental Army, observed and described the forces from Massachusetts early in 1776. Graydon derisively singled out the Marblehead

${ }^{260}$ Daniel Vickers, “Ashley Bowen of Marblehead: Revolutionary Neutral,” in Nancy L. Rhoden and Ian K. Steele, eds., The Human Tradition In the American Revolution (Wilmington, DE: Scholarly Resources Inc., 2000), 99-115.

${ }^{261}$ Smith, ed., The Journals of Ashley Bowen (1728-1813) of Marblehead, Vol. 2, 522.

${ }^{262}$ See the first-hand accounts described in "Journal of Rev. Joshua Wingate Weeks, Loyalist Rector of St. Michael's Church, Marblehead, 1778-1779," Essex Institute Historical Collections, Vol. 52, (Salem, MA: Essex Institute Press, 1916), 1-16, 161-176, 197-208, 345-356; and "Essex County Loyalists," Essex Institute Historical Collections, Vol. 43, (Salem, MA: Essex Institute Press, 1907), 289-316.

${ }^{263}$ See the discussion in chapter two.

${ }^{264}$ Magra, “'Soldiers... Bred to the Sea'," 549-550. 
regiment, noting that "in this regiment there were a number of Negroes, which to persons unaccustomed to such associations, had a disagreeable, degrading effect." 265 AfricanAmericans' service in this port town's regiment was probably a function of fish merchant's commercial ties to the Southern and West Indian plantations. Slaves could have been purchased, as they were in Rhode Island, and imported as chattel. ${ }^{266}$ Prior to the war, when an abolitionist fever swept Massachusetts, they, like Cato Prince, could have been manumitted. Like the slaves in the Southern plantations who fled to Lord Dunmore after his emancipation proclamation, slaves in New England probably decided to fight for whichever side they believed offered them the most freedom. ${ }^{267}$

Since there was no indication of women having worked in the industry prior to the war, it comes as no surprise that there is no evidence of female workers in the fishing industry in Marblehead providing military service. ${ }^{268}$ Women certainly played supporting roles as camp followers for the Continental Army, and a few females masqueraded as men and actually fought for the Army. ${ }^{269}$ The same gender norms that kept women on the margins of the commercial cod fishing industry in New England seem to have shaped the contours of their military service and relegated them to the home front in fishing ports.

\footnotetext{
${ }^{265}$ Quoted in Benjamin Quarles, The Negro in the American Revolution (Chapel Hill: The University of North Carolina Press, 1961), 72.

${ }^{266}$ Robert K. Fitts, Inventing New England's Slave Paradise: Master/Slave Relations In Eighteenth-Century Narragansett, Rhode Island (New York: Garland Pub., 1998).

${ }^{267}$ Cassandra Pybus, Epic Journeys of Freedom: Runaway Slaves of the American Revolution and Their Global Quest for Liberty (Boston: Beacon Press, 2006); Michael Lee Lanning, Defenders of Liberty: African Americans in the Revolutionary War (New York: Citadel Press, 2000); Sylvia R. Frey, Water From The Rock: Black Resistance in a Revolutionary Age (Princeton: Princeton University Press, 1991); and Quarles, The Negro in the American Revolution.

${ }^{268}$ See the discussion in chapter two.

${ }^{269}$ See, Mayer, Belonging to the Army; and Alfred Young, Masquerade: The Life and Times of Deborah Sampson, Continental Soldier (New York: Alfred A. Knopf, 2004).
} 
The British almost certainly also used fishermen in their military. The ebb and flow of the war effort for the British took on some of the characteristics of the migratory fishing industry in peacetime. Whereas West Country migratory vessels, and their naval convoys, typically picked up laborers in Ireland before heading to Newfoundland, the British Navy and Army stopped in Irish ports and recruited thousands of Irish men for military duty before heading to Boston in $1775{ }^{270}$ It is very likely that at least some of these men were among the same maritime laborers who had gone to Newfoundland prior to the Revolution. ${ }^{271}$

In sum, fishermen wore numerous hats and played many significant roles in the American Revolutionary War. The hats fit precisely because they labored as jacks-of-all trades prior to the war. The increasingly market-driven, exploitative nature of the commercial fishing industry in colonial New England motivated desperate workers to take up day labor and work in the merchant marine in addition to their fishing fares in order to provide for their families. The nature of work in the commercial fishing industry provided workers, and, in turn, the American military forces, with a wide-based set of labor skills that could be employed in a number of useful ways. The closing of the commercial cod fishing industry, the backbone of the New England economy, provided workers with scant means to feed their families and earn a living for themselves. The various forms of military service at the colony/state and national levels offered

\footnotetext{
${ }^{270}$ For more on the employment of Irish fishermen in the migratory fishing industry at Newfoundland in the eighteenth century, see W. Gordon Handcock, Soe longe as there comes noe women: Origins of English Settlement in Newfoundland (St. Johns, Newfoundland: Breakwater Books, 1989), 30-31, 133-134. For evidence that British Naval vessels stopped at Irish ports for manpower before coming to America, see NDAR, Vol. 1, 333-336.

${ }^{271}$ More work needs to be done on the role fishermen and the fishing industry played in the British armed forces during the Revolution. Current research on the British military has not explored the role the commercial fishing industry played in providing manpower and vessels for the war effort. See, Buel, Jr., In Irons; David Syrett, The Royal Navy In American Waters, 1775-1783 (Brookfield, Vt.: Gower, 1989); Nicholas Tracy, Navies, Deterrence, \& American Independence: Britain and Seapower in the 1760s and 1770s (Vancouver: University of British Columbia Press, 1988); and Sylvia R. Frey, The British Soldier In America: A Social History of Military Life in the Revolutionary Period (Austin, TX: University of Texas Press, 1981). The same neglect can be found in a recent study of the French Navy. Jonathan R. Dull, The French Navy and American Independence: A Study of Arms and Diplomacy, 1774-1787 (Princeton, N.J.: Princeton University Press, 1975).
} 
wages, prize shares, and bounties for these unemployed men and their families. Merchants on a never-ending quest for profits were able to reap monetary rewards from war-time inflated prices, government contracts, and commission fees. As Lord North so aptly explained to Parliament in 1776, service on the American side offered workers and merchants the added incentive of being able to wreak their revenge on the British state for trying to destroy the cod fishing industry. ${ }^{272}$ By bending the world of commerce to the way of war and by converting the fishing industry into a military machine, America was able to develop its own navy, guard its coast, win battles on land, supply its fighting men with military stores and provisions, and achieve its independence on land and sea.

${ }^{272}$ See the end of chapter four. 


\subsection{CONCLUSION}

Young Alexander plundered India.

He alone?

Caesar beat the Gauls.

Was there not even a cook in his army?

Philip of Spain wept as his fleet

Was sunk and destroyed. Were there no other tears?

Frederick the Second triumphed in the Seven Years' War.

Who triumphed with him?

- “A Worker Reads History,” Bertolt Brecht. ${ }^{1}$

One of the most enduring images of the American Revolutionary War is the painting of George Washington crossing the Delaware River just before the Battle of Trenton. Most Americans have almost certainly seen it, but most probably do not know that the artist was not an American citizen. Emmanuel Gottlieb Leutze, an artist from Dusseldorf, in what is today Germany, was energized by the European revolutions of 1848 and sought to capture in his art the essence of revolutionary spirit. The failure of democratic revolutions in Europe, combined with Leutze's personal admiration for American freedom, inspired him in 1851 to paint his now iconic classic George Washington Crossing the Delaware. ${ }^{2}$

The painting itself is a masterpiece of heroic representation. The image depicts Washington standing proudly as he crosses an ice-choked Delaware River. He is the great man,

\footnotetext{
${ }^{1}$ Bertolt Brecht, Selected Poems, translated by H.R. Hays, (New York: Reynal \& Hitchcock, 1947), 108-109.

${ }^{2}$ For more on Leutze, see Barbara S. Groseclose, Emanuel Leutze, 1816-1868: Freedom Is The Only King (Washington: Published for the National Collection of Fine Arts by the Smithsonian Institution Press, 1975).
} 
lionized at one of his finest hours. One of his legs is thrust forward, as he leans against a longboat's gunwale, his clenched fist silently defying both the inclement nature and the British forces he will soon face. Leutze made Washington the focal point of the painting. With the American flag unfurled to his right, Washington stands amidst a rising sun in the backdrop, reflecting Leutze's hope in revolutionary fulfillment. Below Washington (in every sense) and in the shadows are nine workers rowing the General across the river. They are Marblehead fishermen.

The focus on Washington, in Leutze's painting and in scholarship of the war in general, obscures the accumulated knowledge and labor skills required to transport the Commander-inchief and the Continental Army across an icy river in the dead of night without a single mishap. General Henry Knox recalled the dramatic crossing later during a meeting of the Massachusetts legislature. He stated:

I wish the members of this body knew the people of Marblehead as well as I do. I could wish that they had stood on the banks of the Delaware River in 1776, in that bitter night when the Commander-in-Chief had drawn up his little army to cross it, and had seen the powerful current beating onward the floating masses of ice, which threatened destruction to whoever should venture upon its bosom. I wish that when this occurrence threatened to defeat the enterprise, that they could have heard that distinguished warrior demand, 'Who will lead us on?' and seen the men from Marblehead, and Marblehead alone, stand forth to lead the army along the perilous path to unfading glories and honors in the achievements of Trenton. There, sirs, went fishermen of Marblehead, alike at home upon land or water. ${ }^{3}$

His impassioned, patriotic rhetoric aside, Knox saw, first-hand, the men and the maritime labor skills required for the hazardous winter crossing. Yet, the most recent systematic treatment of

\footnotetext{
${ }^{3}$ Quoted in Samuel Roads, Jr., The History and Traditions of Marblehead, Third ed., (Marblehead: N. Allen Lindsay \& Co., 1897), 177. An abridged version can be found in George Athan Billias, General John Glover and His Marblehead Mariners (New York: Henry Holt and Company, 1960), 16.
} 
the crossing only briefly mentions the fishermen. ${ }^{4}$ Such neglect is symptomatic, characteristic of historical scholarship that has privileged the roles well-educated, propertied, wealthy elites played in the struggle for American independence. ${ }^{5}$

The American Revolution, much like "Washington’s crossing” of the Delaware, did not succeed because of the actions of a few colonial elites. Maritime laborers in the fishing industry put their labor skills to use in a variety of ways during the war. They fought at sea on coast guard vessels, state and Continental warships, and privateers, helping to secure American military command of the sea and permit overseas supplies of gunpowder to pierce the British naval blockade. Fishermen also built sea-coast defenses and fought on land. Some laborers fought on both land and sea in various capacities. Workers in the fishing industry took leading roles in the formation of the first American Navy, the first American coast guard, and the first American Marines. They were also at the siege of Boston and enlisted in the Continental Army in 1775. Collectively, these efforts helped secure American independence. Fishermen consciously contributed to the making of history. ${ }^{6}$

It is impossible to understand how colonial fishermen were able to perform so many vital military roles during the Revolution without coming to terms with the nature of their maritime labor. The commercial fishing industry became increasingly market-driven during the eighteenth

\footnotetext{
${ }^{4}$ David Hackett Fischer, Washington's Crossing (Oxford: Oxford University Press, 2004), 21-22. This book won the 2005 Pulitzer Prize in history. For more on this event, and the role Marbleheaders played, see George Athan Billias, General John Glover and His Marblehead Mariners (New York: Henry Holt and Company, 1960). Billias mentions the fact that the men were fishermen, but he does not discuss life and labor in the commercial cod fishing industry.

${ }^{5}$ Recent scholarly accounts of the Revolution that privilege one social group over another include Gordon S. Wood, Revolutionary Characters: What Made the Founders Different (New York: Penguin Press, 2006); and Bernard Bailyn, To Begin the World Anew: the Genius and Ambiguities of the American Founders (New York: Knopf, 2003).

${ }^{6}$ One the same page that he famously cited "the enormous condescension of posterity" for historians' failure to integrate laborers into a study of the Industrial Revolution, E.P. Thompson defined "agency of working people" as "the degree to which they contributed by conscious efforts to the making of history." E.P. Thompson, The Making of the English Working Class (London: Gollancz, 1963), 13.
} 
century as the means of production expanded far beyond the purchasing power of individual workers. In their struggle to earn a living for themselves and their families, fishermen frequently did day labor and work in the merchant marine in addition to their employment on commercial fishing vessels. Such occupational variety provided men with a set of labor skills that prepared them to earn money and provide political support in a variety of ways during the Revolutionary War. George Washington himself recognized that unemployed maritime laborers possessed knowledge and skills that could be mobilized for war in various and important ways. On October 13, 1775, the commander-in-chief acknowledged fishermen's multi-functional occupational identity and diverse skills when he wrote to his brother, John Augustine Washington, that Marbleheaders were "soldiers...bred to the sea."7 Investigating the commercial fishing industry helps us make sense of the maritime dimensions of the American Revolution, and gets us closer toward understanding the intimate relationship that has always existed between the world of commerce and the way of war.

During the Revolution, a cross-section of the colonial fishing community played important roles in the war effort. Wealthy, educated fish merchants such as Elbridge Gerry, who was one of the "Founding Fathers" that signed the Declaration of Independence, contributed their capital and vessels to the war. Fish merchants were also able to convert trade networks into military supply lines and thereby import much needed military stores from abroad. Yet their stories cannot completely account for the colonial victory. Nor can we attribute the origins of the Revolution solely to their efforts and ideology. ${ }^{8}$

\footnotetext{
${ }^{7}$ John C. Fitzpatrick, ed., The Writings of George Washington, 1745-1799, Vol. 4, (Washington: U.S. Government Printing Office, 1934), 27.

${ }^{8}$ For example, see Bernard Bailyn, The Ideological Origins of the American Revolution, 3rd ed., (Birmingham, Ala.: Palladium Press, 2001; orig. pub. 1967).
} 
The United States was born into an Atlantic world as a result of pressures from within and without the British Empire. It did not rise from the hearts and minds of a few great men. The maritime commercial expansion of the cod fishing industry in New England generated fierce economic rivalries between colonial fish merchants, West Indian planters, West Country fish merchants, and British governmental officials who had to regulate these competing, even contradictory, people and interests. The New England cod fisheries developed primarily as a result of trade with West Indian slave plantations and especially, even illegally, with French merchants. The Yankee cod trade to the French West Indies in turn grated on British planters' nerves and moved them to apply for, and win, Parliamentary protection throughout the eighteenth century. New Englanders wanted to use oceanic highways to distribute their staple commodity to markets where demand and purchasing power were high. The British state, on the other hand, wanted to control their use of Atlantic shipping lanes and restrict trans-oceanic commerce to imperial political boundaries. Colonists also wanted to use the sea to fish for and process cod. The best place to do this in the eighteenth century was the Grand Bank off the coast of Newfoundland, but the British state did not want New Englanders to interfere with West Country migratory fishing operations in the region. This quest for commercial control of the sea caused conflict within the British Empire that resulted in the imperial crisis. Such an account of the origins of the American Revolution moves the sea to center stage and broadens our perspective on this formative event.

Leutze's celebration of the American Revolution, like scholarship that puts Founding Fathers on pedestals, does not spotlight the multitude of actors who performed vital roles in the war for independence. The more we know about workers that risked their lives in the Revolution, the closer we will come to realizing the successes and failures of this formative 
event. Bertolt Brecht was surely right to ask whether anyone helped Alexander the Great and Frederick the Great achieve their military victories. The German poet and the German painter might have asked: who helped Washington, and why? 


\title{
BIBLIOGRAPHY
}

\author{
ABBREVIATIONS
}

EVREC

Early Vital Records of Essex County, Massachusetts to about 1850. Vols.1-3. Salem:

Newcombb \& Gauss, 1903. JCC

Ford, Worthington C., ed. Journals of the Continental Congress, 1774-1789. Vols. 1-34.

Washington, D.C.: U.S. Government Printing Office, 1904-37. JDPL

James Duncan Phillips Library, Salem, Massachusetts JEPCM

Lincoln, William, ed. The Journals of Each Provincial Congress of Massachusetts In 1774 and 1775, And of the Committee of Safety, With An Appendix. Boston: Dutton and Wentworth, 1838. JHRM

Journals of the House of Representatives of Massachusetts, 1762-1779. Vols. 38-55.

Boston: Massachusetts Historical Society, 1968-90. MHS

Massachusetts Historical Society, Boston, Massachusetts MDHS

Marblehead Museum \& Historical Society, Marblehead, Massachusetts $M P R$

Massachusetts Probate Records Middlesex \& Essex Counties, Selected Years (CD-ROM).

Provo, UT: MyFamily.com, Inc., 2000.

MSA

Massachusetts State Archives, Boston, Massachusetts

MSSRW

Massachusetts Soldiers and Sailors of the Revolutionary War, Secretary of the

Commonwealth, comp. Vols. 1-17. Boston: Wright and Potter Printing Co., 1896-1908. MUMHA

Memorial University, Maritime History Archives, St. John’s, Newfoundland NA

National Archives (formerly the Public Records Office), Kew, England SP - Records assembled by the State Paper Office, including papers of the 
Secretaries of State up to 1782.

$\mathrm{T}$ - Records created and inherited by the Treasury Board.

ADM - Records of the Navy Board and the Board of Admiralty.

CO - Records of the Colonial Office, Commonwealth and Foreign and Commonwealth Offices, Empire Marketing Board, and related bodies.

NDAR

Clark, William Bell, et al., eds. Naval Documents of the American Revolution. 11 vols. to date. Washington, D.C.: U.S. Government Printing Office, 1964-. PDBP

Simmons, R.C. and P.D.G. Thomas, eds. Proceedings and Debates of the British Parliaments respecting North America, 1754-1783. Vols. 1-5. Millwood, NY: Kraus International Publications, 1982-1986. PGW

Abbot, W.W. and Dorothy Twohig, eds. The Papers of George Washington: Revolutionary War Series. Vol. 1. Charlottesville: University Press of Virginia, 1985.

\section{PRIMARY SOURCES}

\section{Manuscript Collections}

Boston, Massachusetts

Massachusetts Historical Society

Benjamin Bangs diary, 1742-1765.

Dennys Deberdt Misc. Material.

Elbridge Gerry Papers II, 1770-1848.

Ezekiel Price Papers, 1754-1785.

Ezekiel Price Receipt Book, 1764-1774.

Frost family papers II, 1754-1848.

George Stevens logbook, 1768-1774.

Jasper Mauduit Papers, 1760-1767.

John Powell Letters, 1764-1773.

Massachusetts Shipping Records, 1686-1765, Part III.

Nathan Dane Papers, 1663-1730.

Naval office shipping lists for Massachusetts, 1686-1765.

Samuel Graves Journal, 1774-1776.

Samuel Russell Gerry papers, 1769-1843.

William Bollan Misc. Material.

Massachusetts State Archives

Collections, Vol. 66, Maritime, 1759-1775. 
Kew, England

National Archives (formerly the Public Records Office)

Admiralty Papers

ADM 1: Volume 470: Letters from Senior Officers, Newfoundland: including Admiral Duff, Commodore Palliser, Byron, and Shuldham, 1766-1776.

ADM 1: Volume 5313: Courts Martial Papers: Sir Hugh Pallisser, 1779.

ADM 106: Volume 1141: Miscellaneous in-letters to the Navy Board from correspondents.

Colonial Office Papers

CO 194: Volume 16: Commodore Hugh Palliser’s Fisheries Reports, 1764-1766.

Secretary of State's Papers

SP 78: Volume 242: Miscellaneous letters pertaining to fishing rights around Nova Scotia.

SP 78: Volume 269: Miscellaneous letters pertaining to fishing rights around Newfoundland.

SP 89: Volume 26: Letters from Mr. Worsley and Consul Poyntz to the Secretaries of State, Portugal, January 13 to December 12, 1718.

Treasury Board Papers

T 1: Volume 429: American Customs Records, Miscellaneous Letters.

T 1: Volume 465: North America, Miscellaneous Letters.

Marblehead, Massachusetts

The Marblehead Museum \& Historical Society

Richard Pedrick Account book, 1767-1784.

Thomas Pedrick Account Book, 1760-1790.

Office of the Town Clerk, Abbot Hall

Marblehead Town Records.

Salem, Massachusetts

The James Duncan Phillips Library at the Peabody Essex Museum

Aaron Parsons, Sr., Shipping Papers.

Daniel Rogers Account Book, 1770-1790.

George Corwin Account Books, 1658-1672.

John Stevens Account Book, 1769-1775.

Joshua Burnham Papers, 1758-1817.

Joshua Burnham Shipping Papers.

Log Book of Schooner Chance, 1754-56.

Log Book of Schooner Eagle, 1753.

Log Book of Schooner General Wolfe, 1767-1769.

Log Book of Schooner John, 1762.

Log Book of Schooner Nabby, 1769.

Log Book of Schooner Nancy 1795-1796.

Log Book of Schooner Ruby, 1788.

Log Book of Schooner Salem, 1763-1773. 
Log Book of Schooner Sally, 1769.

Log Book of Schooner St. Peter, 1793.

Log Book of Schooner Vaughan, 1767.

Log Book of Ship Boston, 1778.

Miles Ward Account Book, 1765-1772.

Richard Derby Account Book, 1757-1776.

Salem Impost Office Records, 1762-1768.

Thomas Davis Account Book, 1771-78.

Timothy Orne Ship’s Ledgers, 1758-1768.

Timothy Orne Shipping Papers.

Timothy Orne Account Book, 1762-1767.

William Knight Account Book, 1767-1781.

St. John's, Newfoundland, Canada

Memorial University, Maritime History Archives

Colonial Secretary Letterbooks, 1752-1765.

\section{Newspapers and Pamphlets}

Anonymous. A Short Answer to an Elaborate Pamphlet. London: 1731

Anonymous. Considerations on the Trade to Newfoundland. London, 1745.

Anonymous. Observations on the Case of the British Northern Colonies. London: 1731.

Anonymous. The Case of the British Northern Colonies. London: 1731.

Anonymous. The Case of the Provinces of the Massachusetts Bay and New Hampshire and the Colonies of Rhode Island with Providence Plantations, and Connecticut in New England, and the Province of New Jersey, with respect to the Bill now depending in the Honourable House of Commons, entitled a Bill for the better securing and encouraging the Trade of His Majesty's Sugar Colonies in America. London: 1731

Anonymous. The Importance of the British Sugar Plantations in America to this Kingdom, with the State of their Trade and Methods for Improving it. London: 1731.

Boston Chronicle.

Boston Evening Post.

Boston Gazette.

Connecticut Courant.

De Britaine, William. The Dutch Usurpation. London: 1672. 
Gentleman, Tobias. England's way to win wealth, and to employ ships and mariners: or, A plain description of what great profit, it will bring into the common-wealth of England, by the erecting, building, and adventuring of busses, to sea, a-fishing... London: 1614.

Georgia Gazette.

Independent Journal.

L'Estrange, Sir Roger. A discourse of the fishery briefly laying open, not only the advantages, and facility of the undertaking, but likewise the absolute necessity of it, in order to the wellbeing, both of king, and people... London: 1674.

Malynes, Gerard. Lex Mercatoria. London, 1622.

Massachusetts Spy; Or, Worcester Gazette.

New England Weekly Journal.

Petyt, William. Britannia Languens. London: 1680.

Smith, Simon. The Herring Busse Trade, expressed in Sundry particulars. London, 1641.

The Boston Gazette, and Country Journal.

The Boston News-Letter and New-England Chronicle.

The Massachusetts Spy: Or, American Oracle of Liberty.

The New-Hampshire Gazette.

The New-Hampshire Gazette, and Historical Chronicle.

The New-London Gazette.

The Newport Mercury.

The Norwich Packet and the Connecticut, Massachusetts, New-Hampshire, and --Rhode-Island Weekly Advertiser.

The Pennsylvania Evening Post.

The Providence Gazette.

The Providence Gazette, and Country Journal. 
Virginia Gazette.

Wood, William. A Survey of Trade. London: 1722.

\section{Published Primary Material}

Abbot, W.W., and Dorothy Twohig, eds. The Papers of George Washington: Revolutionary War Series, Vol. 1. Charlottesville: University Press of Virginia, 1985.

Adams, Charles Francis. The Works of John Adams, Second President of the United States, Vols. 1-10. Boston: Little, Brown and Company, 1850-1856.

Arber, Edward, ed. Travels and Works of Captain John Smith, President of Virginia, and Admiral of New England, 1580-1631, Vol. II. New York: Burt Franklin, 1910.

Bollan, William. The importance and advantage of Cape Breton: truly stated and impartially considered. London: Originally printed for J. and P. Knapton, 1746; New York: Johnson Reprint Corp., 1966.

Bridenbaugh, Carl, ed. Gentleman's Progress, The Itinerarium of Dr. Alexander Hamilton, 1744. Chapel Hill: The University of North Carolina Press, 1948.

Burrage, H.S., ed. Early English and French Voyages, Chiefly from Hakluyt, 1534 - 1658. New York: C. Scribner's Sons, 1906.

Butterfield, L.H., ed. The Adams Papers: Diary \& Autobiography of John Adams, Vols. 1-3. New York: Atheneum, 1964.

Clark, William Bell, et al., eds. Naval Documents of the American Revolution, Vols. 1-11. Washington, D.C.: U.S. Government Printing Office, 1964-.

Commager, Henry Steele, and Richard B. Morris, eds. The Spirit of Seventy-Six: The Story of the American Revolution As Told By Participants, 4th ed. New York: Da Capo Press, 1995.

Crawford, Michael J., ed. The Autobiography of A Yankee Mariner: Christopher Prince and the American Revolution. Washington, D.C.: Brassey’s, Inc., 2002.

Cunningham, Anne Rowe, ed. Letters and diary of John Rowe: Boston merchant, 1759-1762, 1764-1779. Boston: W.B. Clarke Co., 1903.

Dickerson, Oliver Morton, comp. Boston Under Military Rule, 1768-1769, As Revealed In A Journal of the Times. Wesport, Conn.: Greenwood Press, 1971; orig. pub., 1936. 
Early Vital Records of Essex County, Massachusetts to about 1850, Vols.1-3. Salem: Newcombb \& Gauss, 1903.

Edmund Burke on Government Politics and Society, edited by B.W. Hill. London: Harvester Press, 1975.

Fitzpatrick, John C., ed. The Writings of George Washington, 1745-1799, Vols. 1-39. Washington: U.S. Government Printing Office, 1931-44.

Ford, Worthington C., ed. Journals of the Continental Congress, 1774-1789, Vols. 1-34. Washington, D.C.: U.S. Government Printing Office, 1904-37.

Journals of the House of Representatives of Massachusetts, 1762-1779, Vols. 38-55. (Boston: Massachusetts Historical Society, 1968-90.

Labaree, Leonard Woods, ed. Royal Instructions to British Governors, 1670-1776. Vols. 1-2. New York: Octagon Books, Inc., 1967.

Lincoln, William, ed. The Journals of Each Provincial Congress of Massachusetts In 1774 and 1775, And of the Committee of Safety, With An Appendix. Boston: Dutton and Wentworth, 1838.

Massachusetts Probate Records Middlesex \& Essex Counties, Selected Years (CD-ROM). Provo, UT: MyFamily.com, Inc., 2000.

Massachusetts Soldiers and Sailors of the Revolutionary War, Secretary of the Commonwealth, comp., Vols. 1-17. Boston: Wright and Potter Printing Co., 1896-1908.

Mossner, E.C., and Ian Simpson, eds. Correspondence of Adam Smith. Oxford: Oxford University Press, 1977.

Simmons, R.C., and P.D.G. Thomas, eds. Proceedings and Debates of the British Parliaments respecting North America, 1754-1783, Vols. 1-5. Millwood, NY: Kraus International Publications, 1982-1986.

Smith, Phillip Chadwick Foster, ed. The Journals of Ashley Bowen (1728-1813), Vols. 1-2. Portland, Maine: The Colonial Society of Massachusetts, 1973.

Tinling, Marion, ed. The Correspondence of the three William Byrds of Westover, Virginia, 1684-1776, Vol. 2. Charlottesville: University Press of Virginia, 1977.

Wood, William. New England's Prospect, edited by Alden T. Vaughan. Amherst, Mass.: University of Massachusetts Press, 1977.

Wroth, L. Kinvin, and Hiller B. Zobel, eds. Legal Papers of John Adams, Vols. 1-3. Cambridge: Harvard University Press, 1965. 


\section{SECONDARY SOURCES}

Abreu-Ferreira, Darlene. "Notes and Comments: Terra Nova through the Iberian Looking Glass: The Portuguese-Newfoundland Cod Fishery in the Sixteenth Century," Canadian Historical Review 79, no.1 (1998), 100-115.

Albion, Robert Greenhalgh. Forests and Sea Power: The Timber Problem of the Royal Navy, 1652-1862. Cambridge: Harvard University Press, 1926.

Albion, Robert G., William A. Baker and Benjamin W. Labaree. New England and the Sea. Mystic, Connecticut: Mystic Seaport Museum, Inc., 1972.

Albion, Robert Greenhalgh, and Jennie Barnes Pope. Sea Lanes In Wartime: The American Experience, 1775-1942. New York: W.W. Norton and Company, Inc., 1942.

Allen, Gardner Weld. A Naval History of the American Revolution, Vols. 1-2. Boston: Houghton Mifflin Company, 1913.

Anderson, Fred. A People's Army: Massachusetts Soldiers \& Society in the Seven Year's War. Chapel Hill: University of North Carolina Press, 1984.

-----. Crucible of War: The Seven Years' War and the Face of Empire in British North America, 1754-1766. New York: Vintage Books, 2000.

Andrews, Charles M. “Anglo-French Commercial Rivalry, 1700-1750: The Western Phase, I,” The American Historical Review, Vol. 20, No. 3 (April, 1915), 539-556.

-----. “Anglo-French Commercial Rivalry, 1700-1750: The Western Phase, II,” The American Historical Review, Vol. 20, No. 4 (July, 1915), 761-780.

-----. The Colonial Background of the American Revolution. New Haven: Yale University Press, 1931.

Andrews, K. R. Trade, Plunder and Settlement: Maritime Enterprise and the Genesis of the British Empire, 1480-1630. Cambridge: Cambridge University Press, 1984.

Applewhite, Harriet B., and Darline G. Levy, eds. Women \& Politics in the Age of the Democratic Revolution. The University of Michigan Press, 1990.

Armitage, David, and Michael Braddick, eds. The British Atlantic World, 1500-1800. London: Palgrave, 2002.

Austin, James T. The Life of Elbridge Gerry, With Contemporary Letters, To The Close of the American Revolution. Boston: Wells and Lilly, 1828. 
Babson, John J. History of the Town of Gloucester, Cape Ann, Including the Town of Rockport. Gloucester, Mass.: Peter Smith Publisher, Inc., 1972; orig. pub. 1860.

Bailyn, Bernard. Atlantic History: Concept and Contours. Cambridge, MA: Harvard University Press, 2005.

-----. The Ideological Origins of the American Revolution. Cambridge: Harvard University Press, 1967.

-----. The New England Merchants in the Seventeenth Century, 3rd ed. Cambridge, Mass.: Harvard University Press, 1982.

-----. The Ordeal of Thomas Hutchinson. Cambridge: Harvard University Press, 1974.

-----. To Begin the World Anew: the Genius and Ambiguities of the American Founders. New York: Knopf, 2003.

Bailyn, Bernard and Lotte Bailyn. Massachusetts Shipping, 1697-1714: A Statistical Study. Cambridge: Harvard University Press, 1959.

Bailyn, Bernard and Philip D. Morgan, eds. Strangers Within the Realm: Cultural Margins of the First British Empire. Chapel Hill: The University of North Carolina Press, 1991.

Baker, Emerson W., et al., eds. American Beginnings: Exploration, Culture, and Cartography in the Land of Norumbega. Lincoln: University of Nebraska Press, 1994.

Baller, William Arthur. "Military mobilization during the American Revolution in Marblehead and Worcester, Massachusetts.” Ph.D. Dissertation, Clark University, 1994.

Bancroft, George. History of the American Revolution. Vols. 1-7. Boston: Little, Brown \& Company, 1852-1874.

Bannister, Jerry. The Rule of the Admirals: Law, Custom, and Naval Government in Newfoundland, 1699-1832. Toronto: University of Toronto Press, 2003.

Barrow, Thomas C. Trade and Empire: The British Customs Service in Colonial America, 16601775. Cambridge: Harvard University Press, 1967.

Baxter, William T. The House of Hancock: Business in Boston, 1724-1775. Cambridge: Harvard University Press, 1945.

Beard, Charles A. An Economic Interpretation of the Constitution of the United States. New York: The Macmillan Company, 1913. 
Beattie, Donald W., and J. Richard Collins. Washington's New England Fleet. Boston: Newcombb and Gauss Co., 1964.

Becker, Carl Lotus. The History of Political Parties In the Province of New York, 1760-1776. Madison: University of Wisconsin Press, 1909.

Beckles, Hilary and Verene Sheperd, eds. Caribbean Slave Society and Economy. New York: New Press, 1991.

Beer, George Louis. The Old Colonial System, 1660-1754. New York: The MacMillan Company, 1912.

Bernstein, Barton J., ed. Towards a New Past: Dissenting Essays in American History. New York: Pantheon Books, 1968.

Billias, George Athan. Elbridge Gerry: Founding Father and Republican Statesman. New York: McGraw Hill Book Co., 1976.

-----. General John Glover and His Marblehead Mariners. New York: Henry Holt and Company, 1960.

-----, ed. George Washington's Generals and Opponents: Their Exploits and Leadership. New York: Da Capo Press, 1994.

Blackburn, Robin. The Making of New World Slavery. London: Verso Press, 1997.

Bolster, W. Jeffrey. Black Jacks: African American Seamen in the Age of Sail. Cambridge: Harvard University Press, 1997.

Bowen-Hassell, E. Gordon, Dennis M. Conrad, and Mark L. Hayes. Sea Raiders of the American Revolution: the Continental Navy in European Waters. Washington: Naval Historical Center, Department of the Navy, 2003.

Boxer, C.R. The Portuguese Seaborne Empire: 1415-1825. New York: Alfred A. Knopf, 1969.

Braddick, Michael J. State Formation in Early Modern England, 1550-1700. Cambridge: Cambridge University Press, 2000.

Braudel, Fernand. The Structures of Everyday Life: Civilization \& Capitalism, $15^{\text {th }}-18^{\text {th }}$ Century, Volume 1, translated by Siân Reynolds. New York: Harper \& Row, Publishers, 1979.

Brecht, Bertolt. Selected Poems. Translated by H.R. Hays. New York: Reynal \& Hitchcock, 1947.

Breen, T.H. The Marketplace of Revolution: How Consumer Politics Shaped American Independence. Oxford: Oxford University Press, 2004. 
Brewer, John. Sinews of Power: War, Money and the English State, 1688-1788. Cambridge: Harvard University Press, 1990.

Bridenbaugh, Carl. Cities In Revolt: Urban Life In America, 1743-1776. New York: Alfred A. Knopf, 1955.

-----. Mitre and Sceptre: Transatlantic Faiths, Ideas, Personalities, and Politics, 1689-1775. New York: Oxford University Press, 1962.

Buel, Richard, Jr. Dear Liberty: Connecticut's Mobilization for the Revolutionary War. Middletown, Conn.: Wesleyan University Press, 1980.

-----. In Irons: Britain's Naval Supremacy and the American Revolutionary Economy. New Haven: Yale University Press, 1998.

Burnett, Edmund Cody. The Continental Congress. New York: MacMillan Company, 1941.

Bushman, Richard L. King and People in Provincial Massachusetts. Chapel Hill: North Carolina University Press, 1985.

Butterfield, Herbert. The Whig Interpretation of History. London: G. Bell and Sons, 1931.

Calhoon, Robert M., Timothy M. Barnes, and George A. Rawlyk, eds. Loyalists and Community in North America. Westport, Conn.: Greenwood Press, 1994.

Calhoon, Robert M. Dominion and Liberty: Ideology in the Anglo-American World, 1660-1801. Arlington Heights, IL: Harlan Davidson, 1994.

-----. The Loyalist Perception and other Essays. Columbia, S.C.: University of South Carolina Press, 1989.

-----. The Loyalists in Revolutionary America, 1760-1781. New York: Harcourt Brace Jovanovich, 1973.

Canny, Nicholas. “Atlantic History: What and Why?” European Review, Vol. 9, No.4 (2001): 399-411.

Carp, E. Wayne. To Starve the Army at Pleasure: Continental Army Administration and American Political Culture, 1775-1783. Chapel Hill: University of North Carolina Press, 1984.

Carrington, Selwyn H.H. The British West Indies During the American Revolution. Providence, RI: Foris Publications, 1988. 
Capp, Bernard. Cromwell's Navy: The Fleet and the English Revolution, 1648-1660. Oxford: Clarendon Press, 1989.

Cell, Gillian T. English Enterprise in Newfoundland, 1577-1660. Toronto: University of Toronto Press, 1969.

Chapelle, Howard I. The Search for Speed Under Sail, 1700-1855. New York: Norton, 1967.

Chapin, Howard Millar. "New England Vessels in the Expedition Against Louisbourg, 1745," New England Historic Genealogical Register, Vol. 77, No. 1 (January, 1923), 95-110.

Chávez, Thomas E. Spain and the Independence of the United States: An Intrinsic Gift. Albuquerque, NM: University of New Mexico Press, 2002.

Christie, Ian R., and Benjamin W. Labaree. Empire or Independence, 1760-1776. New York: W. W. Norton \& Company, Inc., 1976.

Church, Albert Cook. American Fishermen. New York: W.W. Norton \& Company, Inc., 1940.

Churchill, Edwin A. "Too Great the Challenge: The Birth and Death of Falmouth, Maine, 16241676.” Ph.D. Dissertation, University of Maine, 1979.

Claghorn, Charles E. Naval Officers of the American Revolution: A Concise Biographical Dictionary. Metuchen, N.J.: Scarecrow Press, 1988.

Clark, Charles E. The Eastern Frontier: The Settlement of Northern New England, 1610-1763. New York: Alfred A Knopf, 1970.

Clark, William Bell. George Washington's Navy: Being An Account of his Excellency's Fleet in New England. Baton Rouge: Louisiana State University Press, 1960.

-----. Lambert Wickes, Sea Raider and Diplomat: The Story of A Naval Captain of the American Revolution. New Haven: Yale University Press, 1932.

Clemens, Paul G. E. The Atlantic Economy and Colonial Maryland's Eastern Shore: From Tobacco to Grain. Ithaca, NY: Cornell University Press, 1980.

Coclanis, Peter A., ed. The Atlantic Economy During the Seventeenth and Eighteenth Centuries: Organization, Operation, Practice, and Personnel. Columbia, SC: University of South Carolina Press, 2005.

Cogliano, Francis D. American Maritime Prisoners in the Revolutionary War: The Captivity of William Russell. Annapolis, MD: Naval Institute Press, 2001.

Colbourn, Trevor. The Lamp of Experience: Whig History and the Intellectual Origins of the American Revolution. Cambridge: Harvard University Press, 1967. 
Colley, Linda. Britons: Forging the Nation 1707-1837. New Haven, Conn.: Yale University Press, 1992.

Cook, Edward M., Jr. The Fathers of the Towns: Leadership and Community Structure in Eighteenth-Century New England. Baltimore: The Johns Hopkins University Press, 1976.

Cooke, Blanche Wiesen, ed. Past Imperfect: Alternative Essays in American History. New York: Knopf, 1973.

Coull, James R. The Sea Fisheries of Scotland: A Historical Geography. Edinburgh: John Donald Publishers Ltd., 1996.

Countryman, Edward. A People In Revolution: The American Revolution and Political Society in New York, 1760-1790. Baltimore: Johns Hopkins University Press, 1981.

-----. "The Uses of Capital in Revolutionary America: The Case of the New York Loyalist Merchants,” William and Mary Quarterly, 3rd. Ser., Vol. 49, No. 1 (January, 1992), 3-28.

Crane, Elaine Forman. Ebb Tide in New England: Women, Seaports, and Social Change, 16301800. Boston: Northeastern University Press, 1998.

Creighton, Margaret S., and Lisa Norling, eds. Iron Men, Wooden Women: Gender and Seafaring in the Atlantic World, 1700-1920. The John Hopkins University Press, 1996.

Cuadrado, Reyes Calderón. Empresarios españoles en el proceso de independencia norteamericana: La casa Gardoqui e hijos de Bilbao. Madrid: Unión Editorial, 2004.

Cunliffe, Barry. Facing the Ocean: The Atlantic and its Peoples, 8000BC-AD1500. Oxford: Oxford University Press, 2001.

Curtin, Philip D. The rise and fall of the plantation complex, $2^{\text {nd }}$ ed. Cambridge University Press, 1998.

Dalton, Cornelius, John Wirkkala, and Anne Thomas. Leading the Way: A History of the Massachusetts General Court, 1629-1980. Boston: The Office of the Massachusetts Secretary of State, 1984.

Daniels, Christine and Michael V. Kennedy, eds. Negotiated Empires: Centers and Peripheries in the Americas, 1500-1820. New York: Routledge, 2002.

Davis, Ralph. The Rise of the Atlantic Economies. Ithaca, New York: Cornell University Press, 1973.

-----. The Rise of the English Shipping Industry In the $17^{\text {th }}$ and $18^{\text {th }}$ Centuries. London: Macmillan \& Company Limited, 1962. 
Davisson, William I. "Essex County Wealth Trends: Wealth and Economic Growth in $17^{\text {th }}$ Century Massachusetts,” Essex Institute Historical Collections, Vol. 103, (Salem, MA: Newcomb \& Gauss, Co., Printers, 1967), 291-342.

De Vries, Jan, and Ad Van Der Woude. The First Modern Economy: Success, Failure, and Perseverance of the Dutch Economy, 1500-1815. Cambridge: Cambridge University Press, 1997.

Delâge, Denys. Bitter Feast: Amerindians and Europeans in Northeastern North America, 1600-64, translated by Jane Brierley. Vancouver: UBC Press, 1993.

Demos, John. A Little Commonwealth: Family Life in Plymouth Colony. New York: Oxford University Press, 1970.

Dickerson, Oliver M. The Navigation Acts and the American Revolution. Philadelphia: University of Pennsylvania Press, 1954.

Dow, George Francis, Slave Ships and Slaving. New York: Dover Publications, Inc., 1970; first published in 1927.

Dowdell, Vincent, Jr. “The Birth of the American Navy,” U.S. Naval Institute Proceedings, LXXXI (November, 1955), 1251-1257.

Dull, Jonathan R. A Diplomatic History of the American Revolution. New Haven, Conn.: Yale University Press, 1985.

-----. The French Navy and American Independence: A Study of Arms and Diplomacy, 17741787. Princeton, N.J.: Princeton University Press, 1975.

Duncan, T. Bentley. Atlantic Islands: Madeira, the Azores, and the Cape Verdes in SeventeenthCentury Commerce and Navigation. Chicago: University of Chicago Press, 1972.

Dunn, Richard S. Sugar and Slaves: The Rise of the Planter Class in the English West Indies, 1624-1713, $2^{\text {nd }}$ ed. New York: W.W. Norton \& Company, Inc., 1973.

Eccles, W.J. The French in North America, 1500-1783, rev. ed. East Lansing, Michigan: Michigan State University Press, 1998.

Egnal, Marc. A Mighty Empire: The Origins of the American Revolution. Ithaca, New York: Cornell University Press, 1988.

Elder, John R. The Royal Fishery Companies of the Seventeenth Century. Glasgow: Glasgow University Press, 1912. 
Faulkner, Alaric. “Archeology of the Cod Fishery: Damariscove Island,” Historical Archeology, Vol. 19, No. 2 (1985), 57-86.

Ferguson, E. James. The Power of the Purse: A History of American Public Finance, 17761790. Chapel Hill: University of North Carolina Press, 1961.

Fischer, David Hackett. Washington’s Crossing. Oxford: Oxford University Press, 2004.

Fitts, Robert K. Inventing New England's Slave Paradise: Master/Slave Relations In Eighteenth-Century Narragansett, Rhode Island. New York: Garland Pub., 1998.

Foner, Eric. Tom Paine and Revolutionary America. New York: Oxford University Press, 1976.

Foner, Philip S. Labor and the American Revolution. Westport, Conn.: Greenwood Press, 1976.

Forbes, Allyn B. “Greenwich Hospital Money,” New England Quarterly, Vol. 3, No. 3 (July, 1930), 519-526.

Fowler, William M., Jr. Rebels Under Sail: The American Navy During the Revolution. New York: Charles Scribner's Sons, 1976.

Frey, Sylvia R. The British Soldier In America: A Social History of Military Life in the Revolutionary Period. Austin, TX: University of Texas Press, 1981.

-----. Water From The Rock: Black Resistance in a Revolutionary Age. Princeton: Princeton University Press, 1991.

Gardiner, Robert, ed. Navies and the American Revolution, 1775-1783. London: Chatham Publishing, in association with the National Maritime Museum, 1996.

Garrido, Álvaro. "Political Economy and International Trade: The Portuguese Market for Salt Cod and Its Institutions in the Interwar Period," International Journal of Maritime History, Vol. 17, No. 2 (December, 2005), 61-85.

Gibson, Lawrence Henry. The British Empire Before the American Revolution. Vols. 1-15. New York: Alfred A. Knopf, 1939-1970.

Gilje, Paul A. Liberty on the Waterfront: American Maritime Culture in the Age of Revolution. Philadelphia: University of Pennsylvania Press, 2004.

Goebel, Dorothy Burne. "The 'New England Trade' and the French West Indies, 1763-1774: A Study in Trade Policies," The William and Mary Quarterly, $3^{\text {rd }}$ Series, Vol. 20, No. 3 (July, 1963), 331-372.

Goldenberg, Joseph A. Shipbuilding In Colonial America. Charlottesville: Published for the Mariners Museum, Newport News, Virginia, by the University Press of Virginia, 1976. 
Gould, Eliga H. and Peter S. Onuf, eds. Empire and Nation: The American Revolution in the Atlantic World. Baltimore: Johns Hopkins University Press, 2005.

Greene, Jack P. Pursuits of Happiness: The Social Development of Early Modern British Colonies and the Formation of American Culture. Chapel Hill: The University of North Carolina Press, 1988.

-----. Understanding the American Revolution: Issues and Actors. Charlottesville: University Press of Virginia, 1995.

Greene, Jack P., and J.R. Pole, eds. Colonial British America: Essays in the New History of the Early Modern Era. Baltimore: Johns Hopkins University Press, 1984.

Greenhill, Basil. The Merchant Schooners, $2^{\text {nd }}$ ed. Annapolis, MD: Naval Institute Press, 1988; first published in 1951.

Greven, Philip J., Jr. Four Generations: Population, Land, and Family in Colonial Andover, Massachusetts. Ithaca: Cornell University Press, 1970.

Groseclose, Barbara S. Emanuel Leutze, 1816-1868: Freedom Is The Only King. Washington: Published for the National Collection of Fine Arts by the Smithsonian Institution Press, 1975.

Gross, Robert A. The Minutemen and Their World. New York: Hill and Wang, 1976.

Hagan, Kenneth J. This People’s Navy: The Making of American Sea Power. New York: Free Press, 1991.

Hamilton, Earl J. “American Treasure and Andalusian Prices, 1503-1660: A Study in the Spanish Price Revolution,” Journal of Economic and Business History, I (1928), 1-35.

Hancock, David. Citizens of the World: London Merchants and the Integration of the British Atlantic Community, 1735-1785. Cambridge: Cambridge University Press, 1995.

Handcock, W. Gordon. Soe longe as there comes noe women: Origins of English Settlement in Newfoundland. St. Johns, Newfoundland: Breakwater Books, 1989.

Harland, John. Seamanship in the Age of Sail: An Account of the Shiphandling of the Sailing Man-of-War, 1600-1860, Based On Contemporary Sources. Annapolis, MD: Naval Institute Press, 1984.

Harlow, Frederick Pease. Chanteying Aboard American Ships. Meriden, CT: Barre Publishing Company, Inc., 1962. 
Harrington, Faith. "Sea Tenure In Seventeenth Century New England: Native Americans and Englishmen In the Sphere of Marine Resources, 1600-1630.” Ph.D. Dissertation, University of California, Berkeley, 1985.

Hatch, Nathan O. The Sacred Cause of Liberty: Republican Thought and the Millennium in Revolutionary New England. New Haven: Yale University Press, 1977.

Head, C. Grant. Eighteenth Century Newfoundland. Toronto: McClelland and Stewart Limited, 1976.

Hearn, Chester G. George Washington's Schooners: The First American Navy. Annapolis: Naval Institute Press, 1995.

Henretta, James A. "Salutary Neglect”: Colonial Administration Under the Duke of Newcastle. Princeton: Princeton University Press, 1972.

Heyrman, Christine Leigh. Commerce and Culture: The Maritime Communities of Colonial Massachusetts, 1690-1750. New York: W.W. Norton \& Company, 1984.

Higginbothom, Don. “The Early American Way of War: Reconnaissance and Appraisal,” The William and Mary Quarterly, $3^{\text {rd }}$ Ser., Vol. 44, No. 2 (April, 1987), 230-273.

-----. The War of American Independence: Military Attitudes, Policies, and Practice, 1763-1789, $2^{\text {nd }}$ ed. Boston: Northeastern University Press, 1983.

-----. War and Society in Revolutionary America: The Wider Dimensions of Conflict. Columbia, S.C.: University of South Carolina Press, 1988.

Hill, Christopher. Change and Continuity in Seventeenth-Century England. London: Weidenfeld and Nicolson, 1974.

Hindle, Steve. The State and Social Change in Early Modern England, c.1550-1640. New York: St. Martin’s Press, 2000.

Hoerder, Dirk. Crowd Action in Revolutionary Massachusetts, 1765-1780. New York: Academic Press, 1977.

Holm, Poul, Olaf Janzen, and Jón Thór, eds. Northern Seas Yearbook 1995, Association for the History of the Northern Seas. Esbjerg, Denmark: Fiskeri- og Søfartsmuseet, 1995.

Holm, Poul, David J. Starkey and Jón Thór, eds. The North Atlantic Fisheries, 1100-1976. Esbjerg: Fiskeri- og Søfartsmuseets, 1996.

Hornsby, Stephen J. British Atlantic, American Frontier: Spaces of Power In Early Modern British America. Hanover: University Press of New England, 2005. 
Hornsby, Stephen J., and John G. Reid, eds. New England and the Maritime Provinces: Connections and Comparisons. Montreal: McGill-Queen’s University Press, 2005.

Howard, James L. Seth Harding, Mariner: A Naval Picture of the Revolution. New Haven: Yale University Press, 1930.

Howe, Octavius Thorndike. Beverly Privateers In The American Revolution. Cambridge, Mass.: John Wilson and Son, 1922.

Hunter, Brooke. "Wheat, War, and the American Economy during the Age of Revolution," William and Mary Quarterly, $3^{\text {rd }}$ Series, Vol. LXII, No. 3 (July, 2005), 505-526.

Hunter, Phyllis Whitman. Purchasing Identity in the Atlantic World: Massachusetts Merchants, 1670-1780. Ithaca, NY: Cornell University Press, 2001.

Hurst, Ronald. The Golden Rock: An Episode of the American War of Independence, 1775-1783. Annapolis, MD: Naval Institute Press, 1996.

Huston, James A. Logistics of Liberty: American Services of Supply in the Revolutionary War and After. Newark: University of Delaware Press, 1991.

Innes, Stephen. Creating the Commonwealth: The Economic Culture of Puritan New England. New York: W.W. Norton, 1995.

Innis, Harold Adams. The Codfisheries: The History of an International Economy. New Haven: Yale University Press, 1940.

Israel, Jonathan I. The Dutch Republic: Its Rise, Greatness, and Fall, 1477-1806, $4^{\text {th }}$ ed. Oxford: Oxford University Press, 1998.

Jameson, J.F. "St. Eustatius in the American Revolution," The American Historical Review, Vol. 8, No. 4 (July, 1903), 683-708.

-----. The American Revolution Considered As A Social Movement. Princeton: Princeton University Press, 1926.

Jenness, John Scribner. The Isles of Shoals: An Historical Sketch, $3^{\text {rd }}$ ed. Boston: Houghton, Mifflin and Company, 1884.

Jensen, Arthur L. The Maritime Commerce of Colonial Philadelphia. Madison: State Historical Society of Wisconsin for the Department of History, University of Wisconsin, 1963.

Johnson, Sherry. "El Niño, Environmental Crisis, and the Emergence of Alternative Markets in the Hispanic Caribbean, 1760s-70s,” William and Mary Quarterly, ${ }^{\text {rd }}$ Series, Vol. LXII, No. 3 (July, 2005), 365-410. 
Judah, Charles. The North American Fisheries and British Policy to 1713. Urbana, IL: University of Illinois Press, 1933.

Kammen, Michael G. Empire and Interest: The American Colonies and the Politics of Mercantilism. Philadelphia, PA: Lippincott, 1970.

Karras Alan L., and J.R. McNeill, eds. Atlantic American Societies. London: Routledge, 1992.

Karsten, Peter. "The 'New' American Military History: A Map of the Territory, Explored and Unexplored,” American Quarterly, Vol. 36, No. 3 (1984), 389-418.

Keith, Alice B. "Relaxations in the British Restrictions on the American Trade with the British West Indies, 1783-1802,” Journal of Modern History, Vol. 20, No. 1 (March, 1948), 118.

Killingray, David, Margarette Lincoln, and Nigel Rigby, eds. Maritime Empires: British Imperial Maritime Trade in the Nineteenth Century. Rochester, NY: Boydell, in association with the National Maritime Museum, 2004.

Knox, Dudley W. The Naval Genius of George Washington. Boston: Houghton Mifflin, 1932.

Koehn, Nancy F. The Power of Commerce: Economy and Governance in the First British Empire. Ithaca, NY: Cornell University Press, 1994.

Kurlansky, Mark. Cod: A Biography of the Fish That Changed the World. Toronto: Alfred A. Knopf Canada, 1997.

Kupperman, Karen Ordahl, Providence Island, 1640-1641: The Other Puritan Colony. Cambridge: Cambridge University Press, 1993.

Labaree, Benjamin W. Patriots and Partisans: The Merchants of Newburyport, 1764-1815. New York: W.W. Norton \& Company, Inc., 1975.

Labaree, Benjamin W., William M. Fowler, Edward W. Sloan, John B. Hattendorf, Jeffrey J. Safford, and Andrew W. German, America and the Sea: A Maritime History. Mystic, Conn.: Mystic Seaport Museum Publications, 1998.

Labaree, Leonard Woods. Royal Government in America: A Study of the British Colonial System Before 1783. New Haven, CT: Yale University Press, 1930

Lanning, Michael Lee. Defenders of Liberty: African Americans in the Revolutionary War. New York: Citadel Press, 2000.

Lee, Thomas Amory. “The Lee Family of Marblehead,” Essex Institute Historical Collections, Vol. LII-LIII. Salem, MA: Newcomb and Gauss, 1916, 1917. 
Lewis, James A. Neptune's Militia: the Frigate South Carolina During the American Revolution. Kent, Ohio: Kent State University Press, 1999.

Linebaugh, Peter. The London Hanged: Crime and Civil Society in the Eighteenth Century, $2^{\text {nd }}$ ed. London: Verso, 2003.

Linebaugh, Peter and Marcus Rediker. The Many-Headed Hydra: Sailors, Slaves, Commoners, and the Hidden History of the Revolutionary Atlantic. Boston: Beacon Press, 2000.

Lockridge, Kenneth. A New England Town, The First Hundred Years, Dedham, Massachusetts, 1636-1736. New York: W.W. Norton \& Company, 1970.

Lounsbury, Ralph Greenlee. The British Fishery at Newfoundland 1634-1763. New Haven, CT: Yale University Press, 1934.

-----. “Yankee Trade at Newfoundland,” New England Quarterly, Vol. 3, No. 4 (October, 1930), 607-626.

Lydon, James G. "Fish for Gold: The Massachusetts Fish Trade with Iberia, 1700-1773,” The New England Quarterly, Vol.54, No.4 (December, 1981), 539-582.

-----. “North Shore Trade in the Early Eighteenth Century,” American Neptune, Vol. 28, (1968), 261-274.

-----. "Fish and Flour for Gold: Southern Europe and the Colonial American Balance of Payments,” Business History Review, Vol. 39, (1965), 171-183.

Lynd, Staunton. Anti-Federalism in Dutchess County, New York: A Study of Democracy and Class Conflict in the Revolutionary Era. Chicago: Loyola University Press, 1962.

Mackesy, Piers. The War for America, 1775-1783, 3rd ed. Lincoln: University of Nebraska Press, 1992.

Magra, Christopher P. “'Soldiers...Bred to the Sea’: Maritime Marblehead, Massachusetts and the Origins and Progress of the American Revolution,” New England Quarterly, Vol. LXXVIII, No. 4, (December 2004), 531-562.

Mahan, Alfred Thayer. The Influence of Sea Power Upon History, 1660-1783. New York: Dover Publications, Inc., 1987; originally published by Little, Brown, and Company, Boston, in 1890.

-----. The Major Operations of the Navies in the War of American Independence. Boston: Little, Brown, and Company, 1913.

Maier, Pauline. From Resistance to Revolution: Colonial radicals and the development of American opposition to Britain, 1765-1776. New York: Vintage Books, 1972. 
Mancke, Elizabeth and Carole Shammas, eds. The Creation of the British Atlantic World. Baltimore: The Johns Hopkins University Press, 2005.

Maritime Dimensions of the American Revolution. Washington, D.C.: Naval History Division, Department of the Navy, 1977.

Martin, John Frederick. Profits in the Wilderness: Entrepreneurship and the Founding of New England Towns in the Seventeenth Century. Chapel Hill: University of North Carolina Press, 1991.

Massie, Robert K. Dreadnought: Britain, Germany, and the Coming of the Great War. New York: Random House, 1991.

Matthews, Keith. “A History of the West of England - Newfoundland Fisheries.” Ph.D. Dissertation, Oxford University, 1968.

Mattingly, Garrett. The Armada. Boston: Houghton Mifflin, 1959.

Mayer, Holly A. Belonging to the Army: Camp Followers and Community during the American Revolution. Columbia, S.C.: University of South Carolina Press, 1996.

McCusker, John J. How Much Is That In Real Money? A Historical Commodity Price Index for Use as a Deflator of Money Values in the Economy of the United States, $2^{\text {nd }}$ ed. Worcester, Massachusetts: American Antiquarian Society, 2001.

McCusker, John J., and Kenneth Morgan, eds. The Early Modern Atlantic Economy. Cambridge: Cambridge University Press, 2000.

McCusker, John J., and Russell R. Menard. The Economy of British America, 1607-1789. Chapel Hill, North Carolina: The University of North Carolina Press, 1985.

McFarland, Raymond. A History of the New England Fisheries. New York: D. Appleton \& Company, publishers for the University of Pennsylvania, 1911.

McManis, Douglas R. Colonial New England: A Historical Geography. New York: Oxford University Press, 1975.

Meinig, D. W. The Shaping of America: A Geographical Perspective On 500 Years of History, Volume 1, Atlantic America, 1492-1800. New Haven: Yale University Press, 1986.

Middlebrook, Louis F. Maritime Connecticut During the American Revolution, 1775-1783, Vols. 1-2. Salem, Mass.: The Essex Institute, 1925.

Miller, Nathan. Broadsides: The Age of Fighting Sail, 1775-1815. New York: John Wiley \& Sons, Inc., 2000. 
-----. Sea of Glory: A Naval History of the American Revolution. Charleston, South Carolina: The Nautical \& Aviation Publishing Company of America, 1974.

Mintz, Sidney W. Sweetness and Power: The Place of Sugar In Modern History. New York: Viking Press, 1985.

Mitchell, Bruce. "Politics, Fish, and International Resource Management: The British-Icelandic Cod War,” Geographical Review, Vol. 66, No. 2 (April, 1976), 127-138.

Morgan, Edmund S. American Slavery, American Freedom: The Ordeal of Colonial Virginia. New York: W.W. Norton \& Company, 1975.

-----. “The American Revolution: Revisions in Need of Revising,” The William and Mary Quarterly, $3^{\text {rd }}$ Series, Vol. 14, No. 1 (January, 1957), 3-15.

Morgan, Edmund S., and Helen M. Morgan. The Stamp Act Crisis: Prologue to Revolution, $3^{\text {rd }}$ ed. Chapel Hill: The University of North Carolina Press, 1995.

Morgan, William James. Captains to the Northward: The New England Captains in the Continental Navy. Barre, Mass.: Barre Gazette, 1959.

Morison, Samuel Eliot. Admiral of the Ocean Sea: A Life of Christopher Columbus, $2^{\text {nd }}$ ed. New York: Time Incorporated, 1962.

-----. “Elbridge Gerry, Gentleman-Democrat,” New England Quarterly, II (1929), 6-33.

-----. John Paul Jones, A Sailor’s Biography. Boston: Little, Brown and Company, 1959.

-----. Maritime History of Massachusetts, 1783-1860. Boston: Houghton Mifflin, 1921.

-----. The European Discovery of America: The Northern Voyages, A.D. 500-1600. New York: Oxford University Press, 1971.

Morris, Richard B. Government and Labor In Early America. New York: Harper \& Row, Publishers, 1946.

Morse, Sidney G. “State or Continental Privateers?” The American Historical Review, Vol. 52, No. 1 (October, 1946), 68-73.

-----. “The Yankee Privateersman of 1776,” The New England Quarterly, Vol. 17, No. 1 (March, 1944), 71-86.

Multhauf, Robert P. Neptune's Gift: A History of Common Salt. Baltimore: The Johns Hopkins University Press, 1978. 
Namier, Sir Lewis. England in the Age of the American Revolution. London: MacMillan and Co., Limited, 1930.

-----. The Structure of Politics at the Accession of George III. Vols. 1-2. London: MacMillan and Co., Limited, 1929.

Nash, Gary B. The Unknown American Revolution: The Unruly Birth of Democracy and the Struggle to Create America. New York: Viking, 2005.

-----. The Urban Crucible: Social Change, Political Consciousness, and the Origins of the American Revolution. Cambridge: Harvard University Press, 1979.

Nash, R.C. "Irish Atlantic Trade in the Seventeenth and Eighteenth Centuries," The William and Mary Quarterly, $3^{\text {rd }}$ Series, Vol. 42, No. 3 (July, 1985), 329-356.

Neimeyer, Charles Patrick. America Goes to War: A Social History of the Continental Army. New York University Press, 1996.

Norling, Lisa. Captain Ahab Had a Wife: New England Women and the Whalefishery, 17201870. Chapel Hill, N.C.: University of North Carolina Press, 2000.

O’Connor, Raymond G. Origins of the American Navy: Sea Power in the Colonies and the New Nation. Lanham, MD: University Press of America, 1994.

O’Shaughnessy, Andrew Jackson. An Empire Divided: The American Revolution and the British Caribbean. Philadelphia: University of Pennsylvania Press, 2000.

Olson, Alison Gilbert. Making the Empire Work: London and American Interest Groups, 16901790. Cambridge: Harvard University Press, 1992.

Palmer, R.R. The Age of the Democratic Revolution. Vols. 1-2. Princeton: Princeton University Press, 1959-1964.

Papenfuse, Edward C., and Gregory A. Stiverson. "General Smallwood’s Recruits: The Peacetime Career of the Revolutionary War Private,” William and Mary Quarterly, Third Series, Vol. 30, No. 1 (January, 1973), 117-132.

Pares, Richard. Yankees and Creoles: The Trade between North America and the West Indies before the American Revolution. London: Longmans, Green and Co., 1956.

-----. War and Trade in the West Indies, 1739-1769. Oxford: Oxford University Press, 1936.

Parry, John H. "Plantation and Provision Ground: An Historical Sketch of the Introduction of Food Crops into Jamaica,” Revista de historia de America, Vol. 39 (1955), 1-20. 
Patterson, Orlando. The Sociology of Slavery: An Analysis of the Origins, Development and Structure of Negro Slave Society in Jamaica. London: MacGibbon \& Kee, 1967.

Paullin, Charles Oscar. The Navy of the American Revolution: Its Administration, its Policy, and its Achievements. Cleveland: The Burrows Brothers Company, 1906.

Pencak, William. War, Politics, \& Revolution in Provincial Massachusetts. Boston: Northeastern University Press, 1981.

Pocock, J.G.A. The Machiavellian Moment: Florentine Political Thought and the Atlantic Republican Tradition. Princeton: Princeton University Press, 1975.

Pope, Peter E. Fish Into Wine: The Newfoundland Plantation in the Seventeenth Century. Chapel Hill: The University of North Carolina Press, 2004.

Preston, Richard A. "Fishing and Plantation: New England in the Parliament of 1621," The American Historical Review, Vol. 45, No. 1 (October, 1939), 29-43.

Price, Jacob M. Tobacco in Atlantic Trade: The Chesapeake, London and Glasgow, 1675-1775. Brookfield, VT: Variorum, 1995.

Price, Richard. "Caribbean Fishing and Fishermen: A Historical Sketch,” American Anthropologist, Vol. 68, No. 6 (December, 1966), 1363-1383.

Purvis, Thomas L. Revolutionary America, 1763-1800. New York: Facts on File, 1995.

Pybus, Cassandra. Epic Journeys of Freedom: Runaway Slaves of the American Revolution and Their Global Quest for Liberty. Boston: Beacon Press, 2006.

Quarles, Benjamin. The Negro in the American Revolution. Chapel Hill: The University of North Carolina Press, 1961.

Rawlyk, George A. Nova Scotia's Massachusetts: A Study of Massachusetts-Nova Scotia Relations, 1630-1784. Montreal: McGill-Queen’s University Press, 1973.

Rediker, Marcus. Between the Devil and the Deep Blue Sea. Cambridge: Cambridge University Press, 1987.

Rhoden, Nancy L., and Ian K. Steele, eds. The Human Tradition In the American Revolution. Wilmington, DE: Scholarly Resources Inc., 2000.

Roads, Samuel, Jr. The History and Traditions of Marblehead, Third ed. Marblehead: N. Allen Lindsay \& Co., 1897.

Robbins, Caroline. The Eighteenth-Century Commonwealthman: Studies in the Transmission, Development and Circumstance of English Liberal Thought from the Restoration of 
Charles II until the War with the Thirteen Colonies. Cambridge: Harvard University Press, 1959.

Rodríguez-Salgedo. M.J. ed. Armada, 1588-1988. London: Penguin Books in association with the National Maritime Museum, 1988.

Rosenberg, Andrew A., et al. "The history of ocean resources: modeling cod biomass using historical records," Frontiers in Ecology and the Environment, Vol.3, No.2, (2005), 8490.

Royster, Charles. A Revolutionary People at War: The Continental Army and American Character, 1775-1783. Chapel Hill: The University of North Carolina Press, 1979.

Rubin, Vera, and Arthur Tuden, eds. Comparative Perspectives on Slavery in New World Plantation Societies. New York: New York Academy of Sciences, 1977.

Russell-Wood, A. J. R. The Portuguese Empire, 1415-1808: A World On The Move, $2^{\text {nd }}$ ed. Baltimore: The Johns Hopkins University Press, 1998.

Sacks, David Harris. The Widening Gate: Bristol and the Atlantic Economy, 1450-1700. Berkeley: University of California Press, 1991.

Sargent, Walter Leslie. "Answering the Call to Arms: The Social Composition of the Revolutionary Soldiers of Massachusetts, 1775-1783.” Ph.D. Dissertation, University of Minnesota, 2004.

Scheina, Robert L. “A Matter of Definition: A New Jersey Navy, 1777-1783,” The American Neptune, Vol. 39, (July, 1979), 209-218.

Schlesinger, Arthur Meier. The Colonial Merchants and the American Revolution, 1763-1776. New York: Columbia University Press, 1918.

Schwartz, Stuart B. Sugar Plantations in the Formation of Brazilian Society: Bahia, 1550-1835. Cambridge: Cambridge University Press, 1985.

-----, ed. Tropical Babylons: Sugar and the Making of the Atlantic World before the 'Sugar Revolution'. Chapel Hill: The University of North Carolina Press, 2004.

Seafaring In Colonial Massachusetts: A Conference Held By the Colonial Society of Massachusetts, November 21 and 22, 1975. Boston: The Society; distributed by the University Press of Virginia, 1980.

Selesky, Harold E. War and Society in Colonial Connecticut. New Haven: Yale University Press, 1990. 
Sheridan, Richard B. Sugar and Slavery: An Economic History of the British West Indies, 16231775. Baltimore: The Johns Hopkins University Press, 1973.

-----. "The Crisis of Slave Subsistence in the British West Indies during and after the American Revolution,” William and Mary Quarterly, $3^{\text {rd }}$ Series, Vol. 33, No. 4 (October, 1976), 615-641.

-----. "The Molasses Act and the Market Strategy of the British Sugar Planters,” Journal of Economic History, Vol. 17, No. 1 (March, 1957), 62-83.

Shipton, Clifford K. Sibley’s Harvard Graduates. Cambridge: Harvard University Press, 1970.

Shy, John. A People Numerous and Armed: Reflections on the Military Struggle for American Independence. Oxford: Oxford University Press, 1976.

-----. Toward Lexington: The Role of the British Army in the Coming of the American Revolution. Princeton: Princeton University Press, 1965.

Smith, Adam. An Inquiry Into the Nature and Causes of The Wealth of Nations, Max Lerner, ed. New York: The Modern Library, 1937; orig, pub. in 1776.

Smith, Alan K. Creating a World Economy: Merchant Capital, Colonialism, and World Trade, 1400-1825. Boulder, CO.: Westview Press, 1991.

Smith, Billy G. The “Lower Sort”: Philadelphia’s Laboring People, 1750-1800. Ithaca, N.Y.: Cornell University Press, 1990.

Smith, Charles R. Marines in the Revolution: A History of the Continental Marines in the American Revolution, 1775-1783. Washington, D.C.: History and Museums Division, Headquarters, U.S. Marine Corps, 1975.

Smith, Philip C. F., and Russell W. Knight, "In Troubled Waters: The Elusive Schooner Hannah,” The American Neptune, Vol. 30, No. 2, (April, 1970), 3-47.

Smith, Simon D. “Gedney Clarke of Salem and Barbados’s Transatlantic Super-Merchant,” New England Quarterly, Vol. 76, No. 4 (December 2003), 499-549.

Socolow, Susan, ed. The Atlantic Staple Trade, 2 vols. Aldershot, U.K.: Variorum, 1996.

Solow, Barbara L. "Capitalism and Slavery in the Exceedingly Long Run,” Journal of Interdisciplinary History, Vol. 17, No. 4 (Spring, 1987), 711-737.

-----, ed. Slavery and the Rise of the Atlantic System. Cambridge: Cambridge University Press, 1991. 
Sosin, Jack M. Agents and Merchants: British Colonial Policy and the Origins of the American Revolution, 1763-1775. Lincoln, Nebraska: University of Nebraska Press, 1965.

Stackpole, Edouard A. The Sea Hunters: The New England Whalemen During Two Centuries, 1635-1835. Philadelphia: J.B. Lippincott Company, 1953.

Starkey, David J., Chris Reid, and Neil Ashcroft, eds. England's Sea Fisheries: The Commercial Sea Fisheries of England and Wales since 1300. London: Chatham Publishing, 2000.

Steele, Ian K. The English Atlantic 1675-1740: An Exploration of Communication and Community. Oxford: Oxford University Press, 1986.

Stein, Stanley J. and Barbara H. Stein. Silver, Trade, and War: Spain and America in the Making of Early Modern Europe. Baltimore: Johns Hopkins University Press, 2000.

Stephenson, O. W. “The Supply of Gunpowder in 1776,” American Historical Review, Vol. 30, No. 2 (January, 1925), 271-281.

Stout, Neil R. The Royal Navy In America, 1760-1775: A Study of Enforcement of British Colonial Policy in the Era of the American Revolution. Annapolis, MD: The United States Naval Institute, 1973.

Syrett, David. The Royal Navy In American Waters, 1775-1783. Brookfield, VT.: Gower, 1989.

The American Navies of the Revolutionary War. Paintings by Nowland Van Powell. Introduction by Richard B. Morris. New York: G.P. Putnam’s Sons, 1974.

Thompson, E.P. Customs in Common: Studies in Traditional Popular Culture. New York: The New Press, 1992.

-----. The Making of the English Working Class. London: Gollancz, 1963.

Thornton, John. Africa and Africans in the Making of the Atlantic World, 1400-1800, $2^{\text {nd }}$ ed. New York: Cambridge University Press, 1998.

Tobin, Beth Fowkes. “'And there raise yams’: Slaves’ Gardens in the Writings of West Indian Plantocrats,” Eighteenth-Century Life, Vol. 23, No. 2 (May, 1999), 164-176.

Tracy, Nicholas. Navies, Deterrence, \& American Independence: Britain and Seapower in the 1760s and 1770s. Vancouver: University of British Columbia Press, 1988.

Trevelyan, George Otto. The American Revolution. Vols. 1-3. New York: Longmans, Green, and Co., 1899-1907.

Tuchman, Barbara W. The First Salute: A View of the American Revolution. New York: Alfred A. Knopf, 1988. 
Tyler, John W. Smugglers \& Patriots: Boston Merchants and the Advent of the American Revolution. Boston: Northeastern University Press, 1986.

Ubbelohde, Carl. The Vice-Admiralty Courts and the American Revolution. Chapel Hill, University of North Carolina Press, 1960.

Unger, R.W. "The Netherlands Herring Fishery in the late Middle Ages: the False Legend of Willem Beukels of Biervliet,” Viator, 9 (1978), 335-356.

Vickers, Daniel. "`A Knowen and Staple Commoditie': Codfish Prices in Essex County, Massachusetts, 1640-1775," Essex Institute, Historical Collections, Vol. CXXIV, (Salem, MA: Newcomb and Gauss, 1988), 186-203.

-----. “An Honest Tar: Ashley Bowen of Marblehead,” New England Quarterly, Vol. 69, No. 4 (December, 1996), 531-53.

-----, ed. Companion to Colonial America. Malden, Mass.: Blackwell Publishers Ltd., 2003.

-----. Farmers and Fishermen: Two Centuries of Work in Essex County, Massachusetts, 16301830. Chapel Hill: The University of North Carolina Press, 1994.

-----. “Nantucket Whalemen in the Deep-Sea Fishery: The Changing Anatomy of an Early American Labor Force,” The Journal of American History, Vol. 72, No. 2. (September, 1985), 277-296.

-----. "The Price of Fish: A Price Index for Cod, 1505-1892," Acadiensis, Vol. 25, No. 2 (Spring, 1996), 62-81.

-----. Young Men and the Sea: Yankee Seafarers In the Age of Sail. New Haven, Conn.: Yale University Press, 2005.

-----. “Young Men and the Sea: Yankee Seafarers in the Age of Sail: A Roundtable Response," International Journal of Maritime History, Vol. 17, No. 2 (December, 2005), 354-365.

Wallerstein, Immanuel. Mercantilism and the consolidation of the European world-economy. New York: Academic Press, 1980.

-----. The Modern World-System I: Capitalist Agriculture and the Origins of the European World-Economy in the Sixteenth Century. New York: Academic Press, 1974.

Walmsley, Andrew S. Thomas Hutchinson and the Origins of the American Revolution. New York: New York University Press, 1999.

Ward, J.R. British West Indian Slavery, 1750-1834. Oxford: Clarendon Press, 1988. 
Way, Peter. "Rebellion of the Regulars: Working Soldiers and the Mutiny of 1763-1764," The William and Mary Quarterly, $3^{\text {rd }}$ Series, Vol. 57, Issue 4 (October, 2000), 761-792.

Weeden, William B. Economic and Social History of New England, 1620-1789, Vol. 2. New York: Hillary House Publishers, Ltd., 1963.

Wells, Robert V. The Population of the British Colonies in America before 1776: A Survey of Census Data. Princeton, New Jersey: Princeton University Press, 1975.

Wharton, James. The Bounty of the Chesapeake: Fishing in Colonial Virginia, $2^{\text {nd }}$ ed. Charlottesville: The University Press of Virginia, 1973.

Williams, Eric. Capitalism \& Slavery. Chapel Hill: The University of North Carolina Press, 1944.

Williamson, James A. A Short History of British Expansion: The Old Colonial Empire, $3^{\text {rd }}$ ed. London: MacMillan and Co., limited, 1945.

Wilson, Charles. Profit and Power: A Study of England and the Dutch Wars. London: Longmans, Green and Co., 1957.

Wood, Gordon S. Revolutionary Characters: What Made the Founders Different. New York: Penguin Press, 2006.

-----. The Radicalism of the American Revolution. New York: Alfred A. Knopf, 1992.

Wright, Conrad Edick, and Katheryn P. Viens, eds. Entrepreneurs: The Boston Business Community, 1700-1850. Boston: Northeastern University Press, 1997.

Young, Alfred F. “An Outsider and the Progress of a Career in History,” William and Mary Quarterly, $3^{\text {rd }}$ Ser., Vol. 52, No. 3 (July, 1995), 499-512.

-----. Liberty Tree: Ordinary People and the American Revolution. New York: New York University Press, 2006.

-----. Masquerade: The Life and Times of Deborah Sampson, Continental Soldier. New York: Alfred A. Knopf, 2004.

-----. The Democratic Republicans of New York: The Origins, 1763-1797. Chapel Hill: The University of North Carolina Press, 1967.

-----. The Shoemaker and the Tea Party: Memory and the American Revolution. Boston: Beacon Press, 1999.

Zuckerman, Michael. Peaceable Kingdoms: New England Towns in the Eighteenth Century. New York: W. W. Norton and Company, Inc., 1970. 